\author{
UNIVERSIDADE DE SÃO PAULO \\ Instituto de Física \\ Instituto de Biociências \\ Instituto de Química \\ Faculdade de Educação
}

BRUNO RAFAEL SANTOS DE CERQUEIRA

\title{
Uma exposição científica internacional no Brasil: um olhar para as contradições
}




\section{BRUNO RAFAEL SANTOS DE CERQUEIRA}

\section{Uma exposição científica internacional no Brasil: um olhar para as contradições}

Tese de doutorado apresentada ao Instituto de Física, ao Instituto de Química, ao Instituto de Biociências e à Faculdade de Educação da Universidade de São Paulo como requisito parcial para obtenção do título de Doutor em Ensino de Ciências.

Área de concentração: Ensino de Biologia

Orientadora: Profa. Dra. Alessandra Fernandes Bizerra

Versão corrigida 
Autorizo a reprodução e divulgação total ou parcial deste trabalho, por qualquer meio convencional ou eletrônico, para fins de estudo e pesquisa, desde que citada a fonte.

FICHA CATALOGRÁFICA

Preparada pelo Serviço de Biblioteca e Informação do Instituto de Física da Universidade de São Paulo

Cerqueira, Bruno Rafael Santos de

Uma exposição científica internacional no Brasil: um olhar para as contradições. São Paulo, 2019.

Tese (Doutorado) - Universidade de São Paulo. Faculdade de Educação, Instituto de Física, Instituto de Química e Instituto de Biociências.

Orientador: Profa. Dra. Alessandra Fernandes Bizerra

Área de Concentração: Ensino de Biologia.

Unitermos: 1. Biologia - Estudo e ensino; 2. Divulgação científica; 3. Exposições internacionais; 4 . Teoria histórico-cultural da atividade; 5. Contradições. 
Dedico este trabalho aos meus pais Edilson Francisco de Cerqueira e Eliana Santos de Cerqueira e às minhas irmãs Rafaela Santos de Cerqueira e Juliane Santos de Cerqueira por todo amor, carinho, paciência e compreensão em relação ao caminho que escolhi trilhar. 


\section{AGRADECIMENTOS}

À minha querida orientadora Alessandra Fernandes Bizerra pelo carinho e serenidade com que conduziu a orientação do meu trabalho. Não tenho como descrever essa experiência, mas sei que saio dela transformado. Nesse tempo juntos você me ensinou que nem sempre consigo ter controle de tudo, me mostrou que paciência é uma virtude a ser cultivada, e aprendemos juntos que menos, às vezes, é mais. Você acreditou em mim em cada momento. Te admiro pela profissional que você é e pela forma sempre paciente que encara as adversidades do caminho.

À minha família por respeitar o caminho que escolhi trilhar, pela compreensão em relação às ausências nos momentos de alegria e dor e por acreditar que eu poderia sempre mais, carrego comigo a esperança ensinada pelos meus pais de que a educação pode mudar as pessoas.

Ao Rafael que me mostrou sempre o lado bom quando tudo parecia ruim, que sempre escutou minhas reclamações me dando o suporte que eu precisava para a concretização dessa etapa da minha vida.

A todos os meus amigos queridos que me mostraram que aonde vamos criamos famílias que podem nos fornecer suporte, amor e diversão e que tornam a vida mais leve. Mesmo com a possibilidade de esquecer alguém, fica meu agradecimento: Camila, Eloisa, Tito, lara, Marcos, Ana, Bruna, Lígia, Keysy, Elka, Clô, Bruce, Luciane.

Uma trajetória nunca é linear, contínua e uniforme, ela é composta por embates, conflitos e tensões. Nesses momentos, a experiência com o outro é o que nos ajuda a superar nossas próprias contradições. Sabendo da minha impossibilidade de agir sozinho agradeço ao grupo de pesquisas CHOICES (Cultural Historicity Out-of-school Innovations for Communication and Education in Science). O que está materializado aqui é resultado do nosso crescimento conjunto.

Aos diversos mestres que com suas palavras e exemplos me mostraram mais que ensinamentos teóricos, mas exemplos de vidas. Martha Marandino, Jose Artur, Suzana Ursi, Andréa Peripato, Alessandra Viveiro e Marilza. Vocês são profissionais que me inspiram com as suas práticas.

Por fim agradeço ao Programa de Pós-Graduação Interunidades em Ensino 
de Ciências da Universidade de São Paulo por todo suporte e à CAPES (Coordenação de Aperfeiçoamento de Pessoal de Nível Superior) pelo financiamento desta pesquisa. Foi por meio da bolsa concedida que consegui me dedicar, em boa parte do tempo, de forma exclusiva a esse estudo.

Esse trabalho se concretiza com financiamento público, pelo esforço da população brasileira, e busca contribuir para o processo de mudanças em relação à forma como a Ciência e Tecnologia é vista pelos diversos setores da sociedade.

Que juntos possamos lutar e resistir! 
"La mano hizo el trabajo, como el trabajo la mano.

$Y$ pore la trabajo y la mano

la evolución de la mente."

(Trecho do poema "La mano" de autoria de Ernesto Cardenal) 


\section{RESUMO}

CERQUEIRA, B. R. S. Uma exposição científica internacional no Brasil: um olhar para as contradições. 175f. Tese (Doutorado) - Instituto de Biociências, Instituto de Química, Instituto de Física e Faculdade de Educação, Universidade de São Paulo, São Paulo, 2019.

As exposições científicas de caráter internacional e itinerante estão presentes em diversos momentos da história da divulgação científica do Brasil e do mundo. Esses grandes eventos também marcam presença na atualidade, através das mostras que buscam apresentar à população as Ciências produzidas em diferentes contextos. Embora historicamente o papel social dessas exposições tenha se alternado em força e motivos, torna-se evidente que esse tipo de iniciativa ainda é recorrente na agenda da divulgação científica do nosso país. Nesse contexto, esta tese compreende uma investigação sobre a vinda ao Brasil da exposição científica, itinerante e internacional "Túnel da Ciência 3.0" desenvolvida pelo Instituto Max Planck, a partir da iniciativa do setor público e privado. A compreensão das negociações e tensões estabelecidas entre diferentes sujeitos envolvidos na significação de uma exposição científica de caráter internacional, sob a ótica da teoria histórico-cultural da atividade é o objetivo principal da pesquisa. A produção de dados foi feita com a utilização de: notas de campo, entrevistas semiestruturadas com organizadores, representante do Ministério da Ciência e Tecnologia, monitores e visitantes, além da gravação em áudio e vídeo das visitas. A sistematização e a análise dos dados foram realizadas com o uso do software NVIVO11 $\AA$, de forma a auxiliar na esquematização dos sistemas de atividade, bem como viabilizar a categorização dos conteúdos das contradições, tendo como base as manifestações discursivas de contradições e o método dialético. Os referenciais utilizados nessa investigação, incluindo os conceitos de sistema de atividade e contradições ofereceram dicas importantes sobre organização das relações que são estabelecidas entre os sujeitos envolvidos com a exposição. Foi possível identificar dez categorias que refletem os conteúdos das contradições de um processo de itinerância de uma exposição científica e internacional. São elas: Ciência local $x$ Ciência global, financiamento público x privado, Aprender conteúdos científicos $x$ explorar os aparatos interativos, divulgação institucional x divulgação das ciências, 
modelos dialógicos $\mathrm{x}$ valores universais, interatividade: discurso midiático x discurso expositivo, negociações: entre o planejado x efetivado, formalização institucional da concepção de divulgação científica $x$ instabilidade política, teoria $x$ prática de monitoria, monitoria junto ao público escolar x monitoria junto ao público espontâneo. A partir da reflexão sobre essas categorias sugerimos elementos centrais a serem considerados nos processos de adaptação de grandes exposições itinerantes e internacionais, que possibilitem a reflexão sobre formas mais contextualizadas desses eventos de modo a atender especificidades locais dos países visitados, contribuindo, assim, para as discussões que envolvem políticas públicas de divulgação das Ciências e tecnologias e a educação não formal.

Palavras-chave: Divulgação científica. Exposições internacionais. Teoria históricocultural da atividade. Contradições. 


\begin{abstract}
CERQUEIRA, B. R. S. An international scientific exhibition in Brazil: a look at the contradictions. 175f. Thesis (doctorate degree) - Institute of Biosciences, Institute of Chemistry, Institute of Physics and Faculty of Education, University of Sao Paulo, São Paulo, 2019.
\end{abstract}

The scientific, international and itinerant exhibitions are present at various moments in the history of the science communication of Brazil and the world. The major events are also present today, through the exhibitions they seek are presented as the sciences produced in different contexts. Although historically the social role of these exhibitions has alternated in strength and motives, it becomes clear that this type of initiative is present in the scientific communication of our country. In this context, this thesis comprises an investigation about the coming to Brazil of the scientific, itinerant and international exhibition "Science Tunnel 3.0" developed by the Max Planck Institute, based on the initiative of the public and private sector. The understanding of the negotiations and tensions established between different subjects involved in the meaning of an international scientific exhibition, from the point of view of the historical-cultural activity theory is the aim of the research. The production of data was done using field notes, semi-structured interviews with organizers, representatives of the Ministry of Science and Technology, monitors and visitors, as well as audio and video recording of visits. The systematization and analysis of the data were performed using the NVIVO11 ${ }_{B}$ software, in order to aid in the schematization of the activity systems, as well as to enable the categorization of the contents of the contradictions, based on the discursive manifestations of contradictions and the dialectical method. The frameworks used in this research, including the concepts of activity system and contradictions, provided important clues about the organization of the relationships that are established among the subjects involved with the exhibition. It was possible to identify ten categories that reflect the contents of the contradictions of a roaming process of a scientific and international exhibition. They are: Local science $x$ Global science, public $x$ private funding, Learning scientific contents $x$ exploring the interactive apparatuses, institutional divulgation $x$ science communication, dialogic models $x$ universal values, interactivity: media discourse $x$ expositive speech, 
negotiations: between the planned $x$ effective, institutional formalization of the concept of scientific communication $\mathrm{x}$ political instability, theory $\mathrm{x}$ practice of monitoring, monitoring with the school public $x$ monitoring with the spontaneous public. From the reflection on these categories, we suggest central elements to be considered in the processes of adaptation of international exhibitions, which allow the reflection on more contextualized forms of these events in order to meet local specificities of the countries visited, thus contributing to the discussions involving public policies for science and technology communication and non-formal education.

Keywords: Science Communication. International exhibition. Cultural-Historical Activity Theory. Contradictions. 


\section{LISTA DE FIGURAS}

Figura 1 - llustração do interior do Palácio de Cristal construido para a exposição universal de 1851 em Londres. Fonte: Hulton Archive

Figura 2 - Estrutura da exposição "Túnel da Ciência 3.0", versão apresentada no Brasil. Fonte: Science Tunnel Max Planck.

Figura 3 - Esquema do comportamento dirigido a um objeto através da mediação. Fonte: adaptado Vygotsky (1978, p. 40).

Figura 4 - Níveis estruturais da atividade humana. (Fonte: adaptado de Leontiev, 2004)

Figura 5 - Estrutura da atividade humana (Fonte: ENGESTRÖM, 1987)

Figura 6 - Interação de duas atividades compartilhando o mesmo objeto. (Fonte: Engeström, 2001, adaptado).

Figura 7 - Os quatro níveis de contradições dentro do sistema de atividade humana. (Fonte: Engeström, 1987)

Figura 8 - Croqui do Espaço expositivo do "Túnel da Ciência 3.0 Max Planck" no Brasil. (Fonte: autoria própria)

Figura 9 - Visão geral de um módulo expositivo. (Fonte: autoria própria)

Figura 10 - Exemplo de painel com textos e imagens. (Fonte: autoria própria)

Figura 11 - Painel touch screen com vídeos. (Fonte: autoria própria)

Figura 12 - Totem com objetos e QR Code (Quick Response Code). (Fonte: autoria própria a)

Figura 13 - Diagrama do envolvimento dos sujeitos com a vinda e realização do Túnel da Ciência 3.0 no Brasil. (Fonte: autoria própria)

Figura 14 - Participantes da pesquisa (Família - Público espontâneo) em situação de visita à exposição, portando o gravador de áudio e vídeo. (Fonte: autoria própria)

Figura 15 - Arquivos das transcrições e visitas inseridos no software NVIVO11 §. (Fonte: autoria própria)

Figura 16 - Divisão da transcrição do Representante do MCTIC em agrupamentos temáticos (subnós). (Fonte: autoria própria)

Figura 17 - Trechos do discurso (Referências) do Representante do MCTIC agrupado no subnó "A exposição". (Fonte: autoria própria)

Figura 18 - Atividade central. (Fonte: autoria própria).

Figura 19 - Possibilidade de leitura das interações entre Atividades central e 
periféricas. (Fonte: autoria própria.

Figura 20 - Caracterização da Atividade do Instituto Max Planck. (Fonte: autoria própria).

Figura 21 - Caracterização da Atividade do Departamento de Popularização e Difusão da Ciência e Tecnologia do MCTI (DEPDI/MCTI). (Fonte: autoria própria).

Figura 22 - Modelo de sistema de Atividade do monitor. (Fonte: autoria própria).

Figura 23 - O movimento no sistema de atividade do monitor. (Fonte: autoria própria).

Figura 24 - Caracterização da Atividade da Produtora Geração. (Fonte: autoria própria).

Figura 25 - (à esquerda) Modelo de atividades de mãe (visitação focada nos conteúdos científicos), (à direita) Modelo de atividade da filha (visitação focada na exploração dos aparatos interativos). Fonte: autoria própria. 


\section{LISTA DE TABELAS}

Tabela 1. Algumas das exposições científicas itinerantes e internacionais ocorridas no Brasil nos últimos quinze anos. 


\section{LISTA DE QUADROS}

QUADRO 1. Componente da Atividade (LIBERALI, 2099, p. 12) 61

QUADRO 2. Aparatos da exposição "Túnel da Ciência 3.0 Max Planck" 77 no Brasil.

QUADRO 3. Identificação e nomes fictícios dos participantes da pesquisa 85

QUADRO 4. O contexto de visitação das três famílias participantes da 90 pesquisa.

QUADRO 5. Síntese das ferramentas de coleta de dados. 92

QUADRO 6. Agrupamentos e subagrupamentos temáticos 98

QUADRO 7. Quadro de categorização dos conteúdos das contradições 119 


\section{LISTA DE ABREVIATURAS E SIGLAS}

BIE - Bureau International des Expositions

C\&T - Ciência e Tecnologia

CGEE - Centro de Gestão e Estudos Estratégicos

CHAT - Cultural-Historical Activity Theory

CHOICES - Culture and Historicity in Out-of-school Innovations for Communication and Education in Science

CRADLE - Center for Research on Activity, Development and Learning

DC - Divulgação Científica

DEPDI - Departamento de Popularização e Difusão da Ciência e Tecnologia

HD - High Definition

MAST - Museu de Astronomia e Ciências Afins

MCTI - Ministério da Ciência, Tecnologia e Inovação

MCTIC - Ministério da Ciência, Tecnologia, Inovações e Comunicações

PIBID - Programa de Bolsas Institucional de Iniciação à Docência

QR Code - Quick Response Code

SECIS - Secretaria de Ciência e Tecnologia para Inclusão Social

SP - São Paulo

TA - Teoria da Atividade

UFSCar - Universidade Federal de São Carlos

UNIFESP - Universidade Federal de São Paulo

USP - Universidade de São Paulo 


\section{SUMÁRIO}

Apresentação - a trajetória: os caminhos dos (des)caminhos

CAPÍTULO 1 - INTRODUÇÃO

1.1 AS EXPOSIÇÕES CIENTÍFICAS ITINERANTES E INTERNACIONAIS: $\quad 30$ UM BREVE PANORAMA

1.1.1. As grandes exposições universais do século XIX. O que há de universal?

1.1.2. As grandes exposições científicas internacionais atuais

1.1.3. Algumas implicações em relação à movimentação das exposições internacionais

2.1. AS RAÍZES DIALÉTICAS DAS CONTRADIÇÕES

2.2 A TEORIA HISTÓRICO-CULTURAL COMO BASE PARA A TEORIA

DA ATIVIDADE

2.3 A TEORIA DA ATIVIDADE

2.3.1. As contribuições de Aleksei Nikolaevich Leontiev (1903-1979)

2.3.2 Engeström e complexificação da atividade humana

2.4 A CONTRADIÇÃO COMO MOTOR DA ATIVIDADE HUMANA

3.1 DEFINIÇÕES DA PESQUISA

3.2 O ESTUDO DE CASO COMO ABORDAGEM METODOLÓGICA

3.2.1 A exposição "Túnel da Ciência 3.0" - um caso a ser estudado

3.3 PARTICIPANTES DA PESQUISA

3.3.1 Envolvimento dos sujeitos com o Túnel da Ciência 
3.4.1 Síntese das ferramentas metodológicas 92

3.5 Organização e análise dos dados 93

3.5.1. Sobre o processo de triangulação 93

3.5.2. Sobre a análise textual discursiva 94

CAPÍTULO 4. OS SITEMAS DE ATIVIDADES EM QUESTÃO

4.1 ATIVIDADE CENTRAL: UM OBJETO COMPARTILHADO 104

4.2 INTERNACIONALIZAÇÃO DA EXPOSIÇÃO 106

4.3 APOIO POLÍTICO - AS TENSÕES NAS RELAÇÕES ENTRE 108 INSTITUIÇÕES

4.4 A VISITAÇÃO DO PÚBLICO ESPONTÂNEO - DE QUAL OU QUAIS ATIVIDADE(S) ESTAMOS FALANDO?

4.5 A ATIVIDADE DE MONITORIA: A TRANSFORMAÇÃO DO OBJETO AO LONGO DO TEMPO

4.6 ATIVIDADE VIABILIZAÇÃO DO TÚNEL DA CIÊNCIA NO BRASIL:

ARTICULAÇÃO ENTRE OBJETIVOS CONFLITANTES

CAPÍTULO 5. CONTRADIÇÕES

5.1 CONTRADIÇÕES DE IDEIAS E VALORES

5.1.1. Ciência local $x$ ciência global

5.1.2. Financiamento público $x$ privado

5.2 MOTIVOS

5.2.1 Divulgação institucional $x$ divulgação das ciências

5.2.2 Aprender conteúdos científicos $x$ explorar os aparatos interativos

5.3 A EXPOSIÇÃO

5.3.1 Modelos dialógicos $\mathrm{x}$ valores universais

5.3.2. Interatividade discurso midiático $x$ discurso expositivo 
5.4.2 Formalização institucional da concepção de divulgação científica $x$ instabilidade política

5.5. MONITORIA

5.5.1. Teoria x prática de monitoria

5.5.2. Monitoria junto ao público escolar $x$ monitoria junto ao público espontâneo

5.6 EM SÍNTESE

CAPÍTULO 6. CONSIDERAÇÕES FINAIS

REFERÊNCIAS

APÊNDICES

APÊNDICE A - Termo de consentimento livre e esclarecido (maiores de 18 164 anos)

APÊNDICE B - Termo de consentimento livre e esclarecido (menres de 18 166 anos)

APÊNDICE C - Lista de exposições universais

APÊNDICE D - Roteiro de Entrevista semiestruturada - Representante do Instituto Max Planck

APÊNDICE E - Roteiro de entrevista semiestruturada - Representante do

Departamento de Popularização e Difusão da Ciência e Tecnologia do Ministério da Ciência, Tecnologia e Inovação

APÊNDICE F - Roteiro de entrevista semiestruturada - Diretor da

Produtora Geração

APÊNDICE G - Roteiro de entrevista semiestruturada com os monitores

APÊNDICE H - Roteiro de entrevista semiestruturada - Público espontâneo

- Pré visita

APÊNDICE I - Roteiro de entrevista semiestruturada - Público espontâneo 


\section{APRESENTAÇÃO - A TRAJETÓRIA: OS CAMINHOS DOS (DES) CAMINHOS}

"Sim, sou eu, eu mesmo, tal qual resultei de tudo,
Espécie de acessório ou sobresselente próprio,
Arredores irregulares da minha emoção sincera,
Sou eu aqui em mim, sou eu."

(Álvaro de Campos)

A primeira parte desse trabalho tem como objetivo apresentar os caminhos que influenciaram a construção do texto aqui apresentado. Por meio dessa reflexão, também olho para trás e me reconstituo enquanto pesquisador e sujeito social para entender qual a relevância do desenvolvimento desta tese para a minha história pessoal e profissional. Com essa seção, pretendo mostrar como foi o desdobramento do trabalho, desde o meu interesse inicial pela linha de pesquisa até o estágio atual do desenvolvimento. Acredito que essa parte seja de grande importância para se entender o contexto no qual foi produzido o que está escrito.

Retomando a minha trajetória pessoal e acadêmica, posso afirmar que venho me constituindo por meio das mãos de muitas pessoas que passam pela minha vida, das relações sociais que foram estabelecidas e dos lugares e culturas que vivenciei. Dificilmente conseguirei descrever todas essas experiências, mas levanto e reflito sobre pontos principais da minha história.

Um fato relevante é a boa vivência com a Biologia na escola, por meio do contato com bons professores. Tais momentos exerceram grande influência na minha escolha profissional. Com a Biologia em mente, ingressei no curso de licenciatura em Ciências Biológicas na Universidade Federal de São Carlos campus São Carlos. Considero importante ressaltar o ingresso separado para as modalidades bacharelado e licenciatura, característica extremamente relevante para entender o rumo da história desse trabalho. Assim como boa parte dos meus colegas de classe, a licenciatura não era uma primeira opção, ela aconteceu devido às circunstâncias de concorrência do vestibular, porém os motivos que me guiavam mudaram ao longo do tempo.

No curso de graduação, tive uma ampla vivência no campo da educação, do primeiro ao último semestre. Cursei disciplinas voltadas para essa área, desenvolvi projetos de iniciação científica em ensino de genética, participei do Programa Institucional de Bolsas de Iniciação à Docência (PIBID), trabalhei como professor voluntário de um curso pré-vestibular desde o primeiro ano da faculdade, como 
professor substituto da rede estadual de São Paulo e tive uma experiência como mediador na exposição "Cabeça Dinossauro". Esse último fato influenciou diretamente a minha decisão de seguir na linha de pesquisa em educação não formal.

Foi a licenciatura em Biologia que me possibilitou dar os primeiros passos rumo à educação científica, pois aprendi a questionar mais fortemente as relações entre Ciências e educação, o que me levou a pensar sobre a importância de se trabalhar em prol da democratização do conhecimento. A conclusão dessa parte da minha história é que, ao olhar para mim, eu estava imerso no ensino de Biologia, vivendo momentos que eu não gostaria que terminassem. Chamo isso de sentido da vida ou felicidade e, como não gostaria que acabasse, resolvi dar o próximo passo depois de finalizada a graduação.

Entre a oportunidade de continuar próximo de onde eu já estava e de arriscar, escolhi a segunda opção. Chego, enfim, ao curso de mestrado do Programa de Pósgraduação Interunidades em Ensino de Ciências, sob a orientação da Prof. ${ }^{a}$ Alessandra Fernandes Bizerra. Talvez ela seja um dos principais motivos da minha escolha em dar um grande passo e de me jogar no desconhecido.

Logo após a publicação do resultado do processo seletivo, o meu pensamento era como sobreviver em São Paulo. Desde o início o meu objetivo era me dedicar integralmente à pós-graduação e para isso eu sabia que precisava conseguir uma bolsa de alguma agência de fomento. Com essa ideia em mente, eu e minha orientadora marcamos a primeira reunião (23 de dezembro de 2013). Não fazia ideia de que a partir desse primeiro contato nasceria o embrião do meu provável projeto de pesquisa de mestrado.

Nesta reunião, a Professora Alessandra me apresentou o "Túnel da Ciência", uma exposição científica internacional que viria ao Brasil no mês seguinte ao nosso encontro, e comentou sobre a possibilidade de trabalhar na coleta de dados que seria desenvolvida pelo antigo Ministério da Ciência, Tecnologia e Inovação e, concomitantemente, de explorar a exposição para desenvolvermos a pesquisa de mestrado.

Para realizar a pesquisa era necessário um projeto, roteiros de entrevistas e um referencial teórico. Começou aí o primeiro desafio da pós-graduação. A minha orientadora me apresentou o referencial teórico com o qual trabalhava e me entregou um livro para me familiarizar com o assunto. Eu não tinha ideia de como o 
caminho seria tortuoso. Decidi novamente arriscar.

No período de um mês, com a ajuda da Professora Alessandra, eu estruturei o projeto da pesquisa a ser realizado tentando, ao máximo, me apropriar de algumas ideias daquela teoria que parecia tão incompreensível e que até hoje me apresenta desafios.

Com o início da exposição ocorrendo no final do mês de janeiro de 2014, tive o primeiro contato com o espaço e os participantes da pesquisa. Foram 23 dias de observações e de coleta da maior parte dos dados que seriam usados no meu trabalho. Esta etapa foi muito desafiadora, pois só tínhamos aquela oportunidade, já que após o período no Brasil a exposição circularia por outros países. Findada a exibição em meados de fevereiro, finalmente me matriculo no mestrado com muitos dados, dúvidas e poucas certezas, sem saber se teria recurso para me manter na nova cidade.

Logo no início do mestrado resolvemos solicitar uma bolsa ao Programa e, com o resultado positivo, pude então me dedicar exclusivamente ao curso, uma escolha minha para vivenciar integralmente o ambiente acadêmico durante a pósgraduação.

Nesse período, um grande desafio foi tentar entender meu referencial teórico e usá-lo como lente para a leitura dos dados. Para isso, cursei disciplinas que tiveram grande contribuição no entendimento da teoria. A realização das disciplinas e os estudos realizados em nosso grupo de pesquisa (CHOICES - Culture and Historicity in Out-of-school Innovations for Communication and Education in Science) permitiram constituir a base desse trabalho que se sustenta na Teoria históricocultural da Atividade ${ }^{1}$. Assim, posso afirmar que tanto a minha formação como este trabalho são frutos das relações pessoais que estabeleci durante esse período.

Um ponto extremamente importante nesses cinco anos de história foi o meu

\footnotetext{
${ }^{1}$ A Teoria Histórico-Cultural da Atividade tem como raízes os trabalhos de psicólogos russos que foram inspirados pelos princípios marxistas, nos anos de 1920 e 1930, sendo Lev Vygotsky o principal representante devido ao seu pionerismo e contribuições para a constituição da Teoria. Como apresentaremos no capítulo "referencial teórico", essa teoria recebeu contribuições de diversos pesquisadores como: Luria, Leontiev, Engeström, entre outros. Na língua inglesa ela é conhecida pela sigla CHAT (Cultural-Historical Activity Theory). Em alguns trabalhos a Teoria Histórico-Cultural da Atividade é denominada como Teoria da Atividade -principalmente aqueles embassados em Leontiev e Engeström (DANIELS, 2011). Ambas denominações serão utilizadas nessa tese, sendo tratadas como sinônimos.
} 
exame de qualificação do mestrado (outubro de 2015). Na ocasião, a banca presente sugeriu a minha transferência para o doutorado direto e, dessa forma, tive que adequar meu projeto para uma trajetória mais longa. Novamente, fiz uma escolha que implicava consequentemente em muitos desafios que decidi enfrentar.

Com o projeto estruturado para atender às exigências de um curso de doutorado, me debrucei sobre a teoria e sobre meus dados e realizei um novo exame de qualificação (setembro de 2016). Esse processo me abriu novos horizontes em relação à pesquisa e, assim, o trabalho que apresento, bem como a teoria que o embasa, não se finda aqui. Ele é apenas um retrato das influências que contribuíram para o pesquisador e ser humano que me tornei até este momento. As possibilidades estão dadas, agora espero partir em busca de novas perguntas.

\section{Sobre a pesquisa}

O Túnel da Ciência, local de estudo desta pesquisa, é uma exposição de caráter científico concebida pelo Instituto Max Planck, uma instituição reconhecida mundialmente por suas relevantes pesquisas e pelo número elevado de laureados com Prêmio Nobel entre seus cientistas.

Desde que foi inaugurado no ano 2000, o Túnel da Ciência percorreu 20 países nos cinco continentes, recebendo mais de nove milhões de visitantes. Após longas negociações entre o governo brasileiro e instituições alemãs, foi fechado um acordo para que o "Túnel da Ciência 3.0" fosse exibido no país. Ao chegar ao Brasil, esta exposição é apresentada em sua terceira edição, sendo exibida anteriormente apenas na Rússia. Neste processo de "importação" diversos atores sociais estiveram envolvidos, desde a negociação inicial, passando pela captação de recursos e formação dos monitores ${ }^{2}$ da exibição.

Somado ao estranhamento de que o alcance da exposição contrasta, sem dúvida, com o fato de não serem observadas na literatura pesquisas ou avaliações tendo esta exposição como local de estudo, este cenário de negociações se configurou como uma excelente oportunidade de investigação.

Assim, por meio de uma investigação de um estudo de caso, nosso principal

\footnotetext{
2 Optamos pelo uso do termo "monitores" por ser assim que os profissionais que atuavam na exposição e que participaram da pesquisa se autointitulavam.
} 
desafio foi desenvolver formas de analisar uma questão complexa a partir de um volume grande de dados, em busca de reflexões sobre um questionamento que se torna evidente no contexto apresentado: entender como se dá o processo de significação da ciência a partir do diálogo entre diferentes culturas. Este é um campo fértil para o uso da lente da perspectiva histórico-cultural da Atividade ao investigar as atividades, conflitos, tensões e contradições imbricadas nessa trajetória.

Nesse contexto, esta pesquisa de doutorado foi desenvolvida com o intuito de contribuir para as reflexões acerca da "universalização das ciências". Esta universalização está possivelmente presente no processo de circulação de grandes exposições científicas que desafiam fronteiras territoriais e expõem a necessidade de refletir sobre as características locais e suas relações com as ciências.

Durante o processo investigativo buscou compreender as negociações e tensões estabelecidas entre diferentes sujeitos envolvidos na significação de uma exposição científica de caráter internacional, sob a ótica da teoria histórico-cultural da atividade. Para isso, foram estabelecidos alguns objetivos que guiaram a investigação, são eles:

- Identificar sistemas de atividades em curso no contexto da exposição Túnel da Ciência 3.0 no Brasil, envolvendo diferentes sujeitos.

- Reconhecer, a partir do referencial da Teoria da Atividade, interações entre tais sistemas, bem como as tensões e manifestações de contradições presentes, considerando possíveis mudanças decorrentes.

- Contribuir para o refinamento do referencial teórico-metodológico de análise de contradições a partir do desenvolvimento de um quadro de categorias que aborda os conteúdos das contradições presentes no processo de itinerância de uma exposição científica e internacional.

\section{Sobre o texto}

O texto foi organizado de modo que o leitor pudesse ter uma maior aproximação do que foi a nossa compreensão do processo de vinda do Túnel da Ciência ao Brasil e as contradições que surgem desse movimento. Dessa forma, no Capítulo 1 apresento uma introdução em que abordo, muito brevemente, alguns cenários da divulgação das ciências e da educação não-formal. Além disso, apresento as justificativas para a realização desse trabalho e o contexto do que 
chamaremos de grandes exposições científicas itinerantes e internacionais. Esse último tópico trará uma problematização acerca dessa modalidade, contribuindopara o entendimento do cenário em que se insere a nossa investigação.

No Capítulo 2, exploro o referencial teórico que serve como base para as nossas escolhas metodológicas e como lente para a nossa análise de dados. Abordo, inicialmente, as raízes do pensamento dialético e sua contribuição para o entendimento do conceito de contradição. Posteriormente, apresento o cenário em que os pensamentos de Vygotsky são desenvolvidos, além das contribuições de Leontiev e Engeström para o desenvolvimento da Teoria histórico-cultural da atividade, esforçando-me para elucidar os principais tópicos da teoria que servirão de base para a análise dos dados. Apresento também o ferramental analítico para compreender a vinda do Túnel da Ciência como um sistema de atividades. Por fim, apresento um quadro metodológico que aborda a identificação das contradições nos contextos do desenvolvimento humano a partir da ideia de que tais elementos são fundamentais para a aprendizagem expansiva.

No Capítulo 3, dediquei-me a reconstituir, a partir da escrita, o Túnel da Ciência 3.0 no Brasil e o processo de coleta dos dados. Para isso, apresento as justificativas das nossas escolhas metodológicas, o nosso local de pesquisa, os participantes que se voluntariaram a colaborar conosco e as técnicas de coleta de dados. Além disso, exploro nesse capítulo a forma como sistematizamos os dados e como buscamos identificar os sistemas de atividade, as contradições presentes e as formas de superação operadas. Como há um volume grande de dados, sujeitos e informações, procurei sistematizar o conteúdo em tabelas e esquemas como forma de facilitar a retomada de partes da leitura.

Nos Capítulo 4 e 5, apresento as análises e discussões realizadas. No quarto capítulo, faço uma primeira aproximação com o contexto que será analisado, apresentando os sistemas de atividade envolvidos e evidenciando as diversas facetas do objeto da atividade central. Essa análise permite compreender o emaranhado de intenções que compõem a vinda da exposição ao Brasil.

A partir da complexidade dos conjuntos de atividades, abordamos no quinto capítulo o delineamento de um quadro das manifestações das contradições e as transformações internas das atividades que emergem a partir das relações entre os sistemas de atividades, bem como as superações operadas pelos participantes.

No Capítulo 6, apresento algumas considerações, indagações e 
encaminhamentos e faço também uma breve síntese do percurso enfrentado ao tratar o contexto analisado a partir do seus movimentos e contradições. 


\section{CAPÍTULO 1 - INTRODUÇÃO}

A pesquisa em ensino de ciências vê-se em um constante desafio de fortalecer uma educação em ciências pautada em questões sociais que emergem das mais diversas esferas da sociedade e que resultam de um contexto em que, cada vez mais, os avanços científicos e tecnológicos demandam tomadas de decisões conscienciosas. Tal situação põe em evidência a urgente necessidade de reflexão sobre as formas como as ciências são apresentadas à sociedade e, para além disso, as relações que são estabelecidas nos locais em que as ciências são desenvolvidas e apresentadas.

Soma-se a esse cenário, o atual contexto político e econômico do nosso país, em que o recurso investido em Ciência e Tecnologia é visto como gasto e não como investimento, evidenciando e escancarando à toda a sociedade o valor que é atribuído às ciências. Ao mesmo tempo são colocadas em debate as relações que foram estabelecidas ao longo da história brasileira entre as ciências e a população em geral.

Tais contextos, acreditamos, não podem ser negligenciados nas pesquisas que buscam discutir as contribuições da educação em ciências para a sociedade. Se considerarmos que os elementos para a superação das contradições relativas às diversas questões sociais devem advir dos conhecimentos produzidos em diferentes setores sociais, a problemática que devemos refletir, enquanto pesquisadores em ensino de ciências, refere-se a como as ciências se inserem nas transformações das sociedades e para a transformaçaõ da sociedade. A reflexão sobre tal questionamento está inserida em uma profunda discussão que, nos tempos atuais, se mostra cada vez mais necessária e que envolve o estabelecimento de diálogos entre as ciências e as especificidades locais.

Para iniciar essa reflexão, faz-se necessário identificar de que modo as ciências são vistas pela sociedade. Nesse sentido, precisamos colocar em evidência as pesquisas sobre a percepção pública da ciência que, nas últimas décadas, vêm sendo consolidadas como norteadoras de políticas públicas de Ciência e Tecnologia (C\&T). Essas pesquisas são importantes fontes de acesso às informações científicas pela população, de representações sociais e visões a respeito dos cientistas, de percepções e atitudes pertinentes a ciência, tecnologia e inovação, bem como de percepção de riscos em relação à possíveis impactos da C\&T (CGEE, 2015). 
No contexto brasileiro, a última pesquisa de percepção pública da ciência promovida pelo antigo Ministério da Ciência, Tecnologia e Inovação (MCTI) em 2015³, com 1962 participantes, revela um cenário que nos expõe, enquanto pesquisadores, a alguns pontos importantes.

Do total de participantes, mais de $60 \%$ responderam ter interesse por ciência e tecnologia, superando temas como esporte e política. Tal resultado é semelhante aos ponderamentos feitos por Castanhari et al. (2013) que ao analisar os dados da pesquisa de percepção pública de 2010 identificou que, contrariamente às preocupações expressas com frequência por alguns cientistas, educadores ou comunicadores da ciência sobre uma suposta onda de pessimismo, medo ou atitudes hostis em relação à ciência e tecnologia, a maioria dos brasileiros possui uma visão otimista, confiante e que expressa, em geral, apoio à ciência.

O estudo de 2015 também disponibiliza indicadores sobre o acesso da população a meios de divulgação científica. Ele aponta que embora a atitude dos brasileiros seja positiva e o interesse por C\&T seja alto, o acesso à informação é limitado, refletindo exemplos marcantes como os seguintes índices: mais de $85 \%$ das pessoas não conseguiram citar o nome de um cientista ou instituição científica e mais de $90 \%$ afirmaram que não têm o hábito de ler materiais sobre C\&T. Tais índices evidenciam um panorama no qual o interesse da população por C\&T não se materializa em ações ou atitudes de aproximação aos meios que têm como objetivo divulgar conhecimentos das ciências.

Além disso, ao analisar a frequência de visitação a museus de ciências e centros de tecnologia, percebemos que pouco mais de $12 \%$ dos entrevistados visitaram esses espaços no último ano, o que demonstra que esse ainda não é um hábito para a maioria da população. Pensando nisso, se defendemos que os museus e exposições científicas podem promover aprendizagem e aproximação entre 0 público e as ciências (BIZERRA, 2009), refletir sobre os dados apresentados é de extrema importância para pautar as políticas de financiamento público da divulgação científica e as ações para popularização da ciência, ainda mais quando é esperado um alcance significativo junto à população em geral.

\footnotetext{
${ }^{3} \mathrm{~A}$ pesquisa de percepção pública da ciência no Brasil de 2015 está disponível em um site que permite que os pesquisadores façam seus próprios levantamentos de dados. Essa fonte de dados foi utilizada para os apontamentos realizados no texto. Disponível em: http://percepcaocti.cgee.org.br/resultados/. Acesso em 20/06/2017.
} 
Entretanto, além do contingente populacional alcançado pelas exposições científicas, é necessário refletir sobre as ciências que estão sendo apresentadas, as estratégias utilizadas e a apropriação que o público tem dessas iniciativas. Pensar nessas questões nos leva a entender a necessidade de expansão das pesquisas sobre as estratégias de divulgação das ciências, de modo que elas possam subsidiar as ações nessa área.

Sobre as estratégias utilizadas para se inserir e estabelecer um diálogo entre as ciências e o público não especializado, podemos citar numerosas vertentes e categorizações nas quais as ações de divulgação científica podem ser enquadradas, que longe de apresentarem um consenso, buscam separar tais estratégias de acordo com seus objetivos, ideais, abertura em relação à participação social, dentre outros critérios.

Como apontado por Durant (1996, p. 235), uma exposição pode ser entendida "como um ato de interpretação", logo os seus produtores optariam por apresentar uma determinada visão particular do tema, escolhendo-a dentre outras possibilidades também relevantes. Esse processo implica em uma enorme responsabilidade e exige um posicionamento ideológico. Nesse sentido, deve-se ter clareza sobre "que história se quer contar" ao elaborar uma exposição.

A visão de Durant sobre como as ciências são apresentadas em uma exposição pode ser contextualizada a partir de modelos que abordam como a comunicação pública das ciências é estabelecida. Dentro de um espectro simplista os modelos variam de acordo com a maior ou menor participação do público. De acordo com Baumgarten (2012, p. 87), os modelos de divulgação científica poderiam ser situar entre dois polos:

O primeiro enquadramento reúne as concepções que partem da ideia
de uma sociedade segmentada entre leigos e especialistas, e é
imperativo que os conhecimentos científicos sejam transmitidos -
com toda conotação determinista e assimétrica que este termo pode
encerrar - aos não privilegiados, em um esquema do déficit
cognitivo. Por outro lado, no esquema contextual as ações de
divulgação da informação científica são veiculadas
circunstancialmente, levando-se em conta o cenário social particular
ao desenvolvimento da produção de conhecimento e geração de
tecnologias.

Outros autores, como Bucchi (2008), Irwin (2008) e Trench (2008), também vêm se esforçando para estabelecer um quadro que possa abranger os tipos de comunicação pública das ciências, bem como os objetivos que se estabelecem para 
cada um deles.

Segundo Oliveira e Loureiro (2015) que realizaram uma sistematização dos tipos de comunicação pública das ciências presentes nas produções dos autores citados anteriormente, podemos indentificar três principais modelos: deficit, diálogo e participatório.

Destacam-se duas orientações distintas, em uma ponta encontramos a tese do déficit (no nível de conhecimentos), na qual os processos de comunicação se situam em uma única direção, desde os cientistas/divulgadores das ciências até a sociedade, sendo o ponto em questão a disseminação da informação. Em outra ponta, as teses do diálogo e da participação que propõem processos dialógicos de comunicação, com práticas mais contextualizadas e que consideram a diversidade de públicos. Nesses casos, a participação e a postura ativa do público são o foco de atenção (LEWENSTEIN, 2003; HOUSE OF LORDS, 2000).

Segundo Lewenstein (2003), o modelo dialógico não aponta para grandes avanços em relação à participação do público, uma vez que desconsidera muitas das respostas dos indivíduos no que se refere à informação. Já no modelo de participação os vários públicos da ciência são incluídos nas discussões e nos debates das questões científicas, com vistas a garantir uma compreensão mútua e, fundamentalmente, de estabelecer uma tomada de decisão conjunta e democrática.

O diálogo entre comunidade científica e cidadãos deixa de ser
apenas uma questão de conhecimento, passando a ser também de
governança. Focalizado nos aspectos políticos que envolvem os
conhecimentos científicos e tecnológicos, apoiando-se nos ideais
democráticos de uma ampla participação cidadã nos processos
decisórios e atribui autoridade ao público sobre as políticas e os
recursos. (OLIVEIRA; LOUREIRO, 2015, p. 160)

Segundo Ferreira (2014), uma tendência observada ultimamente no discurso de pensadores das políticas de popularização da ciência é a de que essas assumam uma visão dialógica na relação com o público, em que são considerados os interesses e os conhecimentos gerais e específicos da população, e que superem a chamada transmissão unidirecional do conhecimento. Massarani e Moreira (2004, p. 34) indicam direcionamentos para mudanças desse cenário, enfatizando a importância de "questões inerentes ao processo, como o funcionamento do aparato científico, das incertezas, dos riscos e das questões éticas".

Tais discussões, como citei, devem ir além de meras categorizações. São 
temáticas urgentes e necessárias no contexto do nosso país, haja vista os atuais cortes de financiamento de ações de divulgação científica e o desmonte de setores do Ministério da Ciência, Tecnologias, Inovações e Comunicação. Assim, pensar no contexto ideológico das nossas ações é afirmar, em termos políticos, o direcionamento que as ciências devem assumir em sua relação com a sociedade.

No contexto da crescente importância da educação em ciências e da busca por fornececimento de subsídios para um processo educativo atrelado aos nossos tempos, investigações que articulem diferentes espaços (onde os conhecimentos científicos são instrumentos mediadores) tornam-se relevantes e pertinentes para a discussão sobre como as ciências são postas em diálogo com os diversos setores da sociedade.

Esse trabalho insere-se no campo da pesquisa em ensino de ciências e da educação não formal. ao buscar compreender tensões perceptíveis através dos discursos dos participantes da pesquisa, e pode indicar as contradições presentes nas negociações estabelecidas entre diferentes sujeitos (visitantes, monitores, curadores, divulgadores da ciência, produtores, cientistas, representantes políticos) envolvidos em uma atividade de significação de uma exposição científica internacional. Apresenta ainda, interfaces com outras áreas de conhecimento, como a Comunicação Científica e a Filosofia das Ciências, objetivando uma compreensão mais alargada do papel social dessas exposições, cada vez mais comuns no cotidiano brasileiro e que merece um olhar reflexivo.

Com base no que foi exposto até aqui é importante discutir qual o papel das exposições itinerantes internacionais em garantir processos mais participatórios em suas práticas.

Como o foco de nossa pesquisa está prioritariamente em entender as contradições presentes no processo de vinda de uma grande exposição científica internacional e itinerante ao Brasil, na próxima seção abordaremos um recorte histórico dessa temática. Deste modo, iniciaremos discorrendo sobre os elementos presentes na história das grandes exposições científicas internacionais e itinerantes, explorando os objetivos e ideais envolvidos econcluiremos a seção apresentando quais as principais características das ciências que são apresentadas em tais eventos, de forma a delinear um panorama que possa balizar a discussão dos nossos resultados. Finalizaremos o capítulo apresentando na última seção o problema de pesquisa que impulsionou todo o trabalho desenvolvido nesta tese. 
Algumas perguntas irão guiar essa apresentação, a saber: como as questões locais aparecem nas exposições itinerantes que envolvem diferentes países? Como são negociados os aspectos específicos relacionados a essas atividades? Quais relações de poder são estabelecidas? Quais as intenções dos grupos envolvidos com esses eventos? Adianto, porém, que não pretendo encerrar esta discussão. Apenas almejo discutir alguns elementos que nos mostram que as ciências estão longe de conseguirem se eximir de fatores sociais.

Como defendem alguns estudos sociais que abordam as ciências e tecnologias, podemos entender as ciências como dependentes da articulação de uma rede de sustentação que envolve política, representação pública, legislação, divulgação, comunicação, alianças com indústrias e governo etc. (STENGERS, 2002; KNORRR-CETINA, 1999; LATOUR, 2000; LAW, 2005)

\subsection{AS EXPOSIÇÕES CIENTÍFICAS ITINERANTES E INTERNACIONAIS: UM BREVE PANORAMA}

"Com que espírito é preciso visitar a Exposição? É preciso vê-la com o mesmo espírito que presidiu a sua organização: é preciso vê-la para se instruir e para se divertir. Ela é para todo mundo, para todas as idades, para os sábios, assim como para os menos instruídos, uma incomparável "lição de coisas". O industrial aí encontra os modelos dos quais ele saberá aproveitar. O simples passante aí toma um ideia geral e suficiente das maravilhas, sempre em progresso, da indústria moderna. Um pode aí encontrar o caminho da fortuna, pelo estudo dos processos aperfeiçoados de fabricação, outro aí encontra, com os objetos usuais colocados sob seus olhos, a satisfação econômica do seu gosto". ${ }^{4}$

"Chega ao Brasil a maior e mais interativa exposição de educação para as ciências do mundo. O Túnel da Ciência Max Planck 3.0 se apresenta de 30 de janeiro a 21 de fevereiro de 2014, no Centro de Convenções do Shopping Frei Caneca, cidade de São Paulo, situado na Rua Frei Caneca, 569, Bairro da Consolação. O Túnel da Ciência, realizado pela Sociedade Max Planck, abordará os grandes temas da pesquisa básica desde o seu ponto de partida, mostrando as possibilidades e oportunidades científicas e tecnológicas para as inovações mais transformadoras do futuro." ${ }^{5}$

${ }_{4}$ Guide Bleu du Figaro et du Petit Journal. Paris. Exposition de 1889, p.5. Tradução de: GOMES, Ana Carolina; PICCOLO, Priscilla; REY, Ricardo. Exposições Universais: Sociedade no século XIX. Núcleo de Estudos Contemporâneos, Universidade Federal Fluminense, Niterói, 2011.

5 Slogan da exposição "Túnel da Ciência 3.0" e disponibilizado no site do evento: 
Umas das maneiras de aproximar a população dos conhecimentos, embates e contextos das ciências é por meio da realização de exposições científicas que, em geral, estão ligadas às universidades, centros de pesquisas, museus, centros de ciências, empresas especializadas, entre outros (MOURA, 2009).

A elaboração e viabilização dessas iniciativas requer a participação de diversos atores sociais que interagem imbuídos de ideais, motivos e concepções de ciências. Assim, entendemos que há uma organização complexa envolvida nesse processo e que merece ser analisada.

O desenvolvimento de ações que possam colocar o cenário científico em diálogo com o grande público ocupa cada vez mais os debates no meio acadêmico, político e científico, nos quais se questiona, entre outros pontos, quais estratégias devem ser utilizadas. Segundo Souza (2009), as discussões sobre concepção e viabilização das exposições podem ser consideradas potencialmente relevantes no meio social. Essa relevância se relaciona com a ideia de que tais estratégias expositivas podem cumprir o papel de permitir uma maior participação do público na discussão de temas científicos.

Nesse sentido, e considerando o contexto desta pesquisa que busca compreender o movimento de vinda de uma grande exposição científica internacional itinerante ao Brasil, acredito ser válido considerar a historicidade dos processos que possam ter relação com o nosso objeto de pesquisa, que subsidiam as nossas discussões sobre o intercâmbio de exposições entre diferentes países.

O recorte que selecionamos para iniciar a discussão foi o movimento das grandes exposições universais que no início buscava apresentar ao mundo as inovações da ciência e tecnologia. Tais objetivos ficam claros no primeiro trecho apresentado no início desta seção, que está relacionado ao grande evento ocorrido em 1989 na cidade de Paris, a Exposição Universal de 1889 comemorativa do centenário da Revolução Francesa. Como marco desse evento foi construída a Torre Eiffel, com o objetivo de representar a grandiosidade e o potencial da tecnologia e da indústria (PESAVENTO,1997). Esse evento faz parte de uma série de grandes exposições internacionais que buscava reunir as inovações industriais de vários países, exibindo os avanços tecnológicos que foram alcançados ao longo dos anos. 
No segundo trecho temos o sumário de apresentação da exposição "Túnel da Ciência 3.0", local deste estudo e parte de um movimento das grandes exposições científicas, itinerantes e internacionais frequentes na atualidade que abordaremos com mais detalhes a seguir.

Em um primeiro momento seria inaceitável colocar os dois movimentos no mesmo plano de comparação, porém o objetivo dessa seção vai além de um resgate histórico, trabalho já realizado por outros autores (PESAVENTO, 1997; SANTOS, 2013, NEVES, 1986; MOURA, 2009). Penso ser mais frutífera para o trabalho a identificação do contexto das exposições universais e das grandes exposições científicas internacionais, em busca de elementos relacionados às motivações que embasam a realização de tais eventos. Tal estudo é fundamental para entender as raízes ideológicas de estratégias que buscam divulgar as ciências e tecnologias em caráter internacional.

Acredito que seja importante refletir sobre quais aspectos principais, de exposições separadas por mais de um século de história, podem indicar aproximações e distanciamentos. Pretendo assim, nesse capítulo, buscar uma linha de pensamento que desenovele o emaranhado de intenções envolvidas na internacionalização de exposições científicas, para isso buscamos pontos na história da divulgação brasileira que nos ajudam a embasar a discussão sobre a inserção desses tipos de exposições no contexto do nosso país.

\subsubsection{As grandes exposições universais do século XIX. O que há de universal?}

A história da divulgação científica no Brasil nos mostra que a elaboração de exposições científicas se encontra como uma das primeiras iniciativas nesse campo. Ao analisar o cenário histórico da divulgação científica no Brasil, Moreira e Massarani (2002) apontam que a elaboração de exposições científicas nacionais figurava entre uma das primeiras iniciativas de popularização das ciências no Brasil, na metade do século XIX, juntamente com os periódicos, notícias em jornais, cursos populares promovidos pelo Museu Nacional do Rio de Janeiro, bem como conferências públicas de ciências, apontadas como relevantes espaços históricos de discussão científica. Os autores apontam ainda que: 
que passou a ser realizada tinha como característica marcante a ideia de aplicação das ciências às artes industriais. O interesse do imperador $d$. Pedro II pela ciência também favoreceu algumas atividades ligadas à difusão dos conhecimentos. (MOREIRA; MASSARANI, 2002, p. 46).

Esse cenário se une, no âmbito internacional, ao movimento de ufanismo em relação ao progresso científico e técnico, decorrente principalmente da segunda revolução industrial na Europa. O momento histórico em questão foi berço para o surgimento das grandes exposições universais que reuniam periodicamente diversos países para apresentar seus avanços científicos e tecnológicos.

O movimento ufanista sobre o qual trato nessa seção tem início com as feiras com caráter de exposição e comércio que já vinham sendo praticadas desde o fim do século XVIII na França e inicio do XIX na Inglaterra. Esses eventos tinham características locais, com interesses mais regionais de trocas comerciais e incrementos na agricultura e indústria (SANTOS, 2013).

Inspirada nessas iniciativas a Inglaterra, em 1951, decidiu agregar outros países a esses eventos, marcando assim o que se denominou à época de Grande Exposição de trabalhos da indústria de todas as nações, participando deste primeiro evento vinte e cinco países e 15 colônias inglesas (SANTOS, 2013). Foi nesse contexto que foi inagurada a $1^{\text {a }}$ exposição universal, em maio de 1851 , na capital Londres.

Para abrigar esse grande evento foi montado o grande Palácio de Cristal (figura 1), símbolo da grandeza que anunciava uma nova forma de cooperação entre ciência, técnica e indústria (PESAVENTO, 1997). As máquinas expostas eram ícones dos tempos modernos e ciência e técnica conjugavam-se para promover o progresso, o ideal que fazia caminhar a sociedade (NEVES, 2001). 


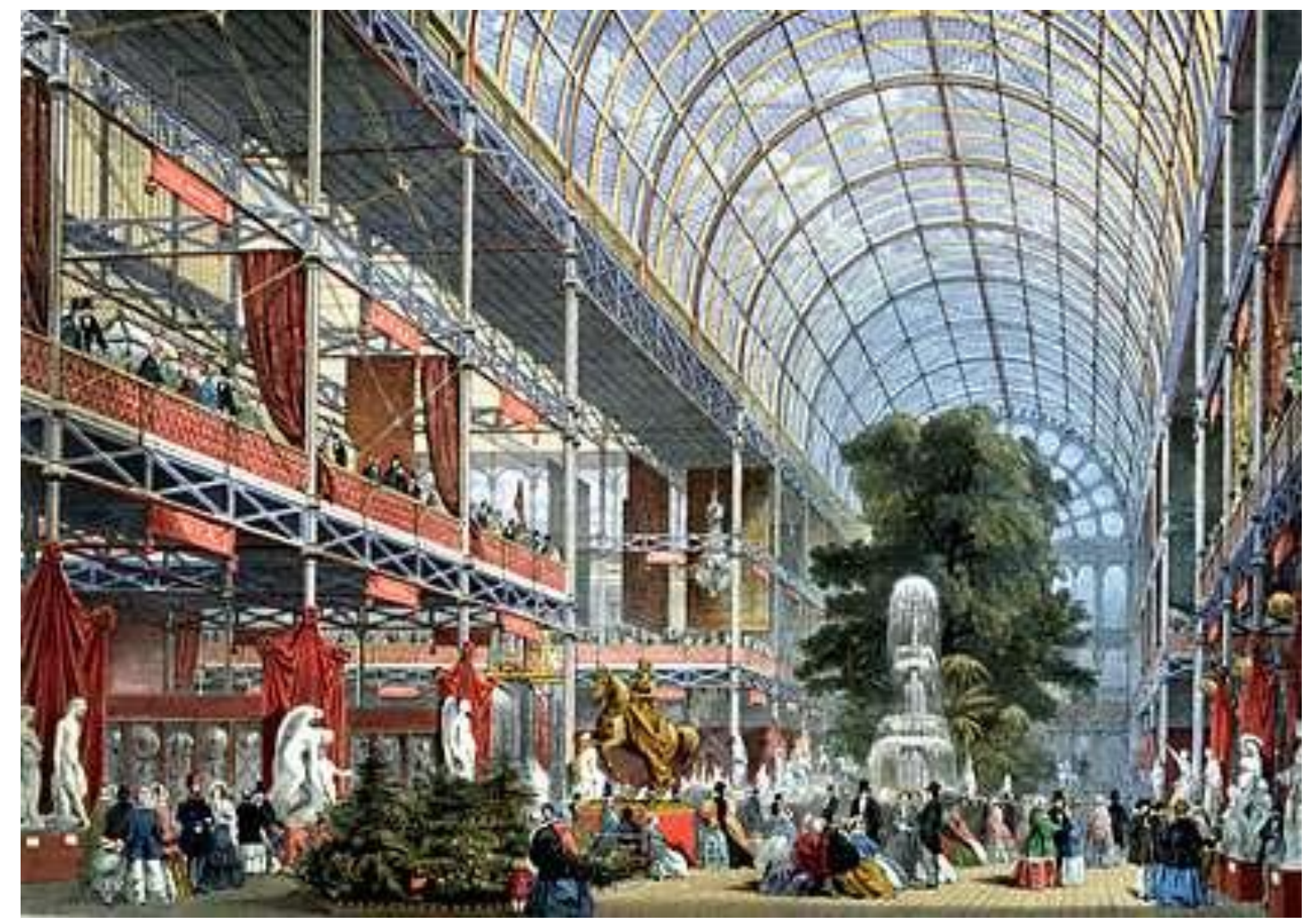

Figura 1 - Ilustração do interior do Palácio de Cristal construido para a exposição universal de 1851 em Londres. Fonte: Hulton Archive. ${ }^{6}$

$\mathrm{Na}$ visão de Barbuy (1996), as primeiras exposições universais podem ser entendidas como uma condensada representação que o projeto capitalista tinha para o mundo naquela época. Nesses eventos, buscava-se reunir em um mesmo espaço representações de regiões que estavam em expansão (Estados Unidos e países europeus emergentes), regiões que estavam em pleno regime colonial e também regiões distantes (do ponto de vista imperialista), que promissoras fontes de matérias-primas, como a América Latina. Uma verdadeira representação do mundo, tal como concebido pelas ideias dominantes.

O Brasil teve participação nesse movimento, tendo iniciado sua colaboração na exposição universal e internacional que ocorreu em 1862 na London International Exhibition on Industry and Art, como aponta Ferreira (2014). Ainda segundo o autor, o ingresso do Brasil esteve intimamente vinculado à ideia de modernização da sociedade que vinha sendo alimentada pelas elites imperiais desde o início do Primeiro Reinado e que atribuía às ciências e tecnologias a esperança do progresso

\footnotetext{
${ }^{6}$ Disponível em: https://www.britannica.com/topic/Crystal-Palace-building-London. Acesso em: 29/11/2018
} 
e da civilização.

Com o objetivo de preparar a organização dos materiais que seriam enviados às exposições universais, no Brasil, assim como em outros países, eram organizadas grandes Exposições Nacionais. Em nosso país elas tiveram início em 1861 e ocorreram também 1862, 1867, 1873, 1876 e 1889 (MOREIRA; MASSARANI, 2002). Elas se concretizaram apesar das várias deficiências e limitações que refletiam também o estado da "arte" nacional. O foco desses eventos era a exibição das ciências em seus aspectos aplicados. Seu objetivo maior era serem vitrines da produção industrial e agrícola do país. A primeira Exposição Nacional teve uma média de 1.127 visitantes por dia, durou 42 dias e ocorreu na Escola Central (Largo de São Francisco, Rio de Janeiro) (MOREIRA; MASSARANI, 2002).

A partir da literatura analisada, é possível perceber a mudança de foco das exposições universais ao longo dos tempos. No quadro que se encontra no Apêndice $C$, sintetizamos as características das diversas edições das exposições universais e, assim, podemos ter um panorama geral das 33 exposições universais ocorridas até então. Em uma breve leitura, é possível perceber a concentração dos eventos em países europeus e norte-americanos como sedes, além do aumento do número de países que se tornaram membros ao longo dos anos. Em relação às temáticas, essas celebram e enfatizam as aplicações das novas tecnologias em prol da modernidade e progresso da sociedade, principalmente na segunda metade do século XIX.

Seria inconsistente não considerar as exposições universais como um marco no estabelecimento de relações internacionais para viabilização de exposições que abordam a ciência e tecnologia, mas quais as influências dessas exposições nas sociedades?

Sobre esse ponto, Santos (2013, n.p.) aponta os valores que embasavam esses eventos na segunda metade do século XIX, entre eles o objetivo de difundir o projeto político burguês:

[...] como grandes laboratórios exibicionistas. Buscava-se mostrar o que as nações haviam feito de progresso industrial". [...] as exposições tinham um caráter pedagógico e imperialista. O caráter universal se ajustava a um novo projeto político que se forjava no século XIX, aliando nacionalismo e burguesia. Esta, desejosa de implantar sua visão de mundo e orgulhosa de si mesma, congratulase com o planeta em expansão comercial. 
Para Pesavento (1997), ao longo da segunda metade do século XIX, era forte o vínculo das exposições universais à difusão de valores civilizatórios ligados às ciências e tecnologia. As exposições universais sempre exerceram um apelo ao mundo que passava pela sedução das promessas da modernidade, do progresso e de valores civilizatórios que pudessem guiar as sociedades em desenvolvimento. Para o autora,

[...] as exposições funcionaram como síntese e exteriorização da modernidade dos "novos tempos" [...]. No papel de arautos da ordem burguesa, tiveram o caráter pedagógico de "efeito demonstração" das crenças e virtudes do progresso, da produtividade, da disciplina do trabalho, do tempo útil, das possibilidades redentoras da técnica, etc.[...] Por meio das exposições, a burguesia encontrou um veículo para circulação não só de mercadorias, mas de ideias em escala internacional [...] foram também elementos de difusão/aceitação de imagens, ideias e crenças pertinentes ao ethos burguês. [...] 0 progresso era necessário e desejável, o capitalismo provocava bemestar, a fábrica era lugar de harmonia e não de conflito, a fraternidade entre os povos era possível de ser mantida. (PESAVENTO, 1997, p. 14-15)

Podemos compreender esse movimento inicial das exposições universais como um cenário propício à difusão de ideais que buscavam representar certos interesses a partir de um recorte da realidade, em que se oculta o que é propício. Garante-se, assim, a universalidade pela abrangência da proposta que atinge diretamente a atividade humana e necessidades da época, apoiada na internacionalização, a partir da colaboração e participação de diversos países. Como aponta Baczko (1985 apud Pesavento, 1997, p. 14):

toda sociedade elabora para si um sistema de representação coletiva, constituída de ideias-imagens que formam como que um esquema de referência para a vida e a compreensão do mundo. Esse imaginário social, assim, constituído, dá legitimidade à ordem vigente, orienta condutas, pauta e hierarquiza valores, estabelece as metas e constrói seus mitos".

Analisando a ideia de universalidade presente nesses eventos, Neves (1986) afirma que:

As exposições passam a ser universais, mesmo se nas primeiras delas o "universo" esteja reduzido a alguns países de Europa Ocidental e aos Estados Unidos: são universais na medida em que esses são países portadores dos valores do progresso, que pela força da lógica inexorável do capital internacionalizado, tantas vezes acompanhado nos novos continentes coloniais pelo argumento das 
armas, transformaria o mundo num novo Império, legitimado desta vez, não pela cristianização do gentio, mas pelos valores da Civilização (NEVES, 1986, p. 19).

Apesar de acontecerem até hoje, as exposições universais possuem outras características, principalmente em relação às temáticas abordadas e à organização. Segundo Barbuy (1999), após a Primeira Guerra Mundial as exposições universais tiveram seus objetivos modificados. As feiras buscam reunir propostas para enfrentar as problemáticas do futuro, usando como ferramenta a agregação de ideias e iniciativas em curso em todos os países que delas participam.

Um marco dessas mudanças ocorreu no ano de 1931, nesse período as exposições universais passaram a ser organizadas e promovidas pela Bureau International des Expositions (BIE). Essa organização foi criada pela Convenção Internacional de 22 de novembro de 1928 em Paris e que tem a representação de 160 países que elegem as cidades-sede e regulamentam a periodicidade e os aspectos legislativos e financeiros dos eventos ${ }^{7}$.

Com o exposto até aqui, podemos entender que a consolidação do movimento das exposições universais aconteceu no bojo da divulgação da ideia do progresso sem fronteiras, buscando a universalização do processo de civilização ocidental, apoiados na difusão de valores, ideais e imagens a partir da valorização de características que são propícias para tal em detrimento de outras.

Se entendemos que o movimento de internacionalização das exposições representa um marco para as mostras que abordam C\&T, como o universal aparece nas grandes exposições científicas itinerantes e internacionais da atualidade semelhantes ao Túnel da Ciências?

\subsubsection{As grandes exposições científicas internacionais atuais}

Em 2014, foi apresentada, na cidade de São Paulo, a exposição foco deste estudo, o "Túnel da Ciências 3.0", uma exposição científica de caráter itinerante e internacional, desenvolvida pelo Instituto Max Planck da Alemanha. Tal exposição buscava apresentar as investigações desenvolvidas por seus pesquisadores e uma

\footnotetext{
7 A Bureau International des Expositions (BIE) mantém um site com a história das exposições universais e as características de cada edicão desses eventos, além de disponibilizar informações sobre o processo de criação da instituição.
} 
projeção do impacto delas na sociedade em trinta anos. Projetada a partir de módulos temáticos e explorando diversos recursos tecnológicos, a exposição visitou diversos países por meio do estabelecimento de parcerias, sendo que até o ano de 2013 acumulava o número de 9 milhões de visitantes ${ }^{8}$.

Em vários meios de comunicação do Brasil, a exposição Túnel da Ciência foi difundida como um grande evento de divulgação das ciências, sendo atribuídos adjetivos relacionados a "interatividade" e modernidade em relação à sua estrutura. Na figura 2 abaixo é possível ter uma noção da estrutura de um dos módulos expositivos.

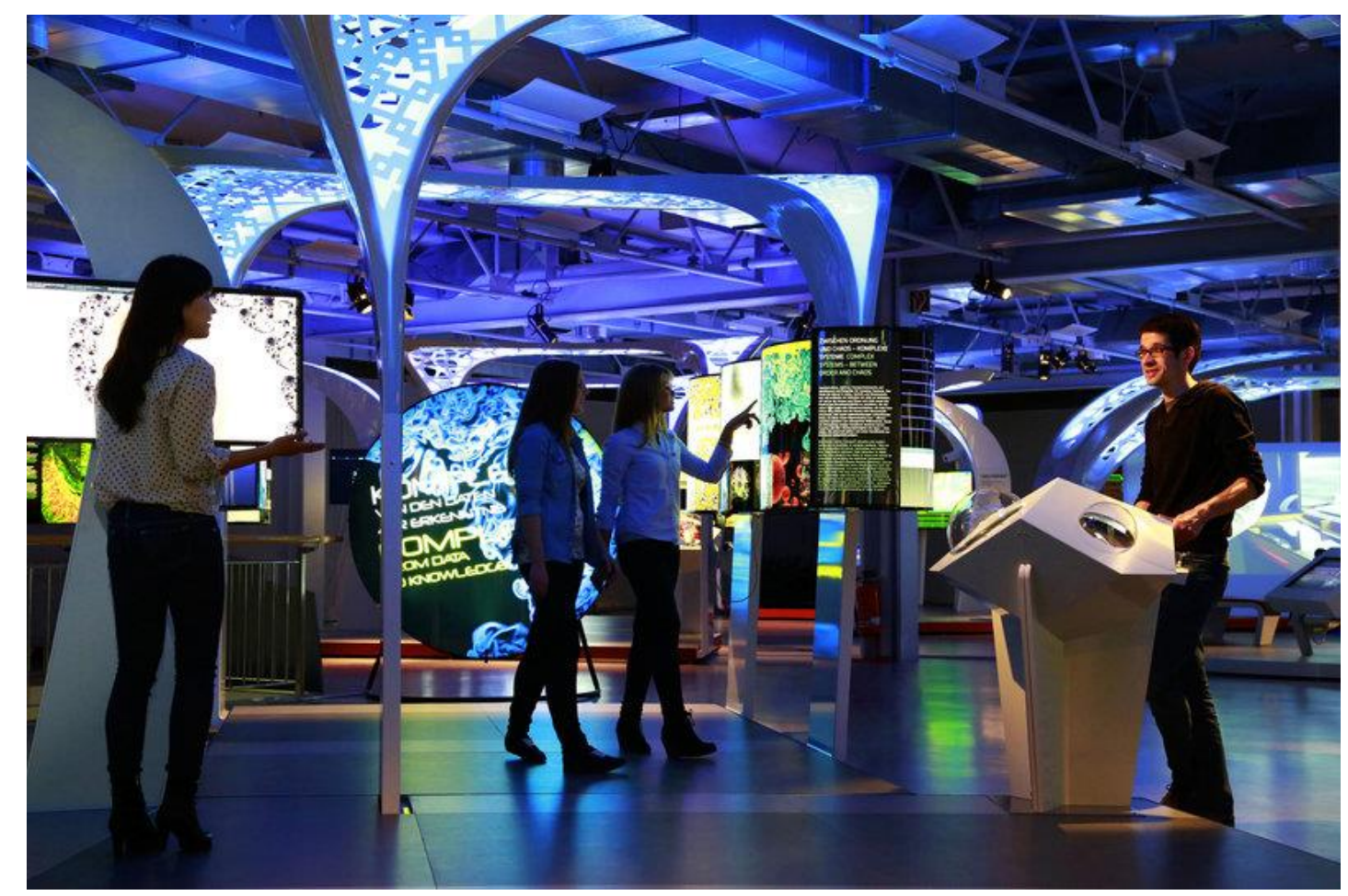

Figura 2 - Estrutura da exposição “Túnel da Ciência 3.0”, versão apresentada no Brasil. Fonte: Science Tunnel Max Planck.

Fotos dos aparatos tecnológicos que possibilitavam a manipulação pelo visitante foram estampadas nos principais portais de notícias do país. ${ }^{9}$ Durante a

\footnotetext{
8 Informação disponibilizada no site original da exposição, no qual são contadas as histórias sobre sua concepção e edições. Disponível em: http://www.sciencetunnel.de/660469/History. Acesso em: 07/07/2018.

9 Os atributos citados no texto foram apresentados em algumas notícias que divulgaram a exposição e, assim, os significados de tais termos podem ter sentidos variados. Um exemplo é a manchete no portal de notícias G1, publicado na época da exibição: http://g1.globo.com/ciencia-e-saude/noticia/2014/01/ciencia-e-tema-central-de-exposicao-
} 
inauguração, representantes políticos, cientistas e empresários se uniram a grupos de escolares e visitantes espontâneos dentro de um shopping de um dos principais bairros do centro da cidade de São Paulo onde a exposição era exibida.

Analisando o contexto apresentado nos pareceu razoável aproximar o "Túnel da Ciência 3.0" de uma tendência que compreende a exibição de grandes exposições científicas itinerantes e internacionais e que vem crescendo em todo o mundo e que se intensificou no Brasil na última década (MOURA, 2009). Embora as exposições desse movimento sejam desenvolvidas para transitar entre diferentes países, sua itinerância não permite grandes modificações principalmente no discurso expositivo e, assim, a principal mudança acaba se limitando à tradução do idioma original. Outros obstáculos também parecem ser relevantes, como a logística de transporte, as negociações intergovernamentais, entre outros.

A nossa escolha por tal enquadramento e recorte é baseada nas ideias desenvolvidas por pesquisadores que tiveram como foco de estudo a massificação das exposições de artes (SANTOS, 2001; SARAIVA; PENTEADO, 2008). Tais autores discutem o papel do que chamam de "megaexposições" como constituintes de um processo de democratização do acesso à arte, bem como sua influência na banalização da arte em sociedades cada vez mais voltadas para o consumo. Os autores buscam analisar a produção, difusão e recepção dessas exposições em busca de elementos que possam caracterizá-las.

No bojo desses estudos, Moura (2009) relacionou o movimento das exposições de arte analisadas pelos autores apresentados com aquelas de caráter científico, apontando características comuns e alguns objetivos semelhantes. $O$ autor também usa o termo megaexposições e, em sua definição, argumenta que tal enquadramento vai além de questões de proporções geralmente atribuídas ao prefixo "mega". O autor identificou características específicas, como o esforço em desenvolver um evento marcante, o forte apelo publicitário direcionado ao grande público, grande uso de aparatos tecnológicos, além da itinerância e internacionalização, como já citado.

No desenvolvimento dessa tese, optamos por intitular tais eventos como exposições científicas itinerantes internacionais. Tal opção foi feita para evitar possíveis incoerências que o termo megaexposições poderia sugerir, como a ideia 
de que estas exposições possam ser mais impactantes ou melhores que outras iniciativas.

Mas como eventos desse porte são concretizados? Quais os motivos que direcionam as atividades? Quando se analisa a viabilização desses eventos, verificase que é seguido um modelo que vem se consolidando no Brasil e no mundo. Um importante ponto é a grande concentração de público e, consequentemente, o patrocínio de empresas privadas já inseridas no circuito brasileiro. As grandes mostras são itinerantes e independentes e, geralmente, promovidas por empresas privadas, centros de ciências ou institutos estrangeiros em parceria com instituições do país-sede (SANTOS, 2001; MOURA, 2009).

Ao analisar os processos de implementação das grandes exposições científicas dos últimos anos, Moura (2009) aponta que um marco pioneiro foi a vinda ao Brasil da exposição "Corpo humano: real e fascinante" que abriu as portas para a realização de outras mostras ao longo da última década, como aquelas viabilizadas pela empresa Time 4 Fun (anteriormente denominada CIE Brasil): "Leonardo da Vinci: a exibição de um gênio" e "Cérebro humano - o mundo dentro da sua cabeça". Destacam-se, ainda, as exposições: "Darwin - descubra o homem e a teoria revolucionária que mudou o mundo", "Revolução Genômica" e "Einstein", organizadas pelo antigo Instituto Sangari, incorporado, em 2012, à empresa Abramundo Educação em Ciências.

Podemos identificar que essas exposições são viabilizadas por um aglomerado de instituições que se reúnem a partir de negociações em prol da concretização desses eventos. Buscando identificar esse contexto, apresentamos abaixo um panorama (Tabela 1) com os dados de algumas das principais exposições científicas itinerantes internacionais que se apresentaram no país nos últimos quinze anos:

Tabela 1. Algumas das exposições científicas itinerantes e internacionais ocorridas no Brasil nos últimos quinze anos. 


\begin{tabular}{|c|c|c|c|}
\hline Nome da Exposição & Ano & Instituições envolvidas & N. de visitantes \\
\hline $\begin{array}{l}\text { Corpo humano: real e } \\
\text { fascinante }\end{array}$ & $\begin{array}{l}2007- \\
2008\end{array}$ & $\begin{array}{l}\text { Time4Fun, Premier Exhibitions e } \\
\text { JAM Exhibitions }\end{array}$ & $670.000^{10}$ \\
\hline $\begin{array}{l}\text { Leonardo da Vinci: a } \\
\text { exibição de um gênio }\end{array}$ & 2007 & $\begin{array}{l}\text { Time4Fun, Anthropos Foundation, } \\
\text { RYP Australia Major Projects }\end{array}$ & $250.000^{11}$ \\
\hline $\begin{array}{l}\text { Darwin - descubra o } \\
\text { homem e a teoria } \\
\text { revolucionária que } \\
\text { mudou o mundo }\end{array}$ & 2007 & $\begin{array}{l}\text { Instituto Sangari, Museu de } \\
\text { História Natural de Nova York, } \\
\text { Museu de Ciências de Boston, The } \\
\text { Field Museum de Chicago, Museu } \\
\text { Real de Ontário no Canadá, } \\
\text { Museu de História Natural de } \\
\text { Londres. }\end{array}$ & $\begin{array}{r}175.000^{12} \\
\text { (somente em } \\
\text { São Paulo) }\end{array}$ \\
\hline Revolução Genômica & 2008 & $\begin{array}{l}\text { Instituto Sangari, Museu de } \\
\text { História Natural de Nova York }\end{array}$ & $170.000^{13}$ \\
\hline Einstein & 2008 & $\begin{array}{l}\text { Instituto Sangari, Museu de } \\
\text { História Natural de Nova York }\end{array}$ & $200.000^{14}$ \\
\hline $\begin{array}{l}\text { Cérebro humano - o } \\
\text { mundo dentro da sua } \\
\text { cabeça }^{15}\end{array}$ & 2009 & $\begin{array}{l}\text { Egg Produções, National Institutes } \\
\text { of Health, The Society for } \\
\text { Neuroscience e The Dana Alliance } \\
\text { for Brain Initiatives }\end{array}$ & Não disponível \\
\hline
\end{tabular}

A partir das informações dessas seis exposições, identificamos características

${ }^{10}$ Informações obtidas em:

http://www.scielo.br/scielo.php?script=sciarttext\&amp;pid=S010493132012000200004

Acesso em: 20/07/2017

${ }^{11}$ Informações obtidas em: https://www1 folha.uol.com.br/fsp/cotidian/ff0904200724.htm

Acesso em: 20/07/2017

12 Informações obtidas em: http://www.darwinbrasil.com.br/ . Acesso em: 20/07/2017

${ }^{13}$ Informações obtidas em: www.revolucaogenomica.com.br . Acesso em: 20/07/2017

${ }^{14}$ Informações obtidas em: http://www.institutosangari.org.br/ . Acesso em: 10/02/2016

15 Informações obtidas em: https://guia.folha.uol.com.br/exposicoes/ult10048u612985.shtml

Acesso em: 20/07/2017 
em comum: parceria com outros países para a sua viabilização, número significativo de público em relação ao tempo de exibição, cenários que impressionam, forte apelo por recursos tecnológicos e uma forte estratégia midiática. Sobre esse último tópico, Moura (2009, p. 4) ressalta que, na exposição "Corpo humano: real e fascinante", a empresa promotora do evento afirmava, em sua apresentação, sobre a possibilidade de oferecimento de "um programa completo de marketing, publicidade e relações públicas para auxiliar as organizadoras em suas campanhas de marketing local e internacional".

Refletindo sobre as informações apresentadas, suscita inquietações o fato de tais exposições transitarem por diferentes países apresentando uma mesma estrutura e discurso, levando-nos a questionar como as especificidades locais são negociadas em tais eventos. Segundo Santos (2001), o fato de ser itinerante faz com que, na elaboração dessas exposições, busque-se uma linguagem unificadora que possa ser conhecida em diversas partes do mundo, além de condições físicas que possibilitem a reprodução de hábitos e costumes. Aponta, porém, que apesar da intencionalidade de universalização das exposições é evidente que, em cada país que as recebem, conflitos e obstáculos são inevitáveis.

Considerando que as sociedades contemporâneas são marcadas por diferentes perspectivas culturais, sociais, políticas e econômicas e, ao mesmo tempo, imersas em um mundo globalizado e fragmentado, é importante questionar sobre as relações estabelecidas no desenvolvimento desses grandes eventos. Como as ciências apresentadas se relacionam com os contextos sociais dos diferentes países envolvidos? Como apresentar uma ciência que não se limite à homogeneização e universalização?

Sobre esse ponto, vários cientistas e divulgadores das ciências, nacionais e internacionais, apontam, em relação às exposições científicas em geral, uma tendência de apresentação de uma 'imagem espetáculo' e 'acrítica' da ciência, em detrimento de uma visão histórica e mais humanizada, que revele os embates na sua construção e as relações entre ciência, tecnologia e sociedade (BARROS, 1992; DÍAZ, 1999; DURANTE, 1996 FAYARD, 1999; GOUVÊA, 2000).

Analisando algumas exposições científicas ligadas a instituições museológicas, Santos (2016) pondera que se tem produzido uma representação da ciência na qual se privilegia o "espetáculo". Segundo o autor, tal conceito está ligado à manipulação da aparência e à supressão do tempo social. Acrescenta ainda que, 
como resultado, se evidencia a fragilidade crítico-reflexiva dessa abordagem que subestima o potencial dialógico e empoderador das exposições. Difunde-se, então, a imagem da ciência como atividade ideologicamente isenta que produz autonomamente conhecimentos universais.

É provável que tais desafios também sejam enfrentados pelos organizadores de grandes exposições científicas itinerantes e internacionais, com o agravante de lidar com seu caráter itinerante, dinamizador da dualidade local $\mathrm{x}$ universal. Apresentado tal panorama, a próxima reflexão visa apontar algumas implicações dessa prática.

1.1.3. Algumas implicações em relação à movimentação das exposições internacionais

O que se oculta/demonstra nesses grandes eventos? Com quais intenções estas escolhas são feitas? Segundo Santos (2009), as grandes exposições atuais inegavelmente se enquadram em um movimento associado com mercados comuns que ocorrem em todo o mundo ligado ao processo de globalização. Por um lado, desafiam as fronteiras locais e, por outro, as dicotomias entre o permanente e 0 transitório e entre o erudito e o popular.

Dentre as possíveis intencionalidades na elaboração de grandes exposições, encontra-se o proporcionamento de lazer para o grande público e de lucro para seus idealizadores, conferindo a estes eventos um caráter de artifícios da indústria cultural. Adicionalmente, percebe-se que as grandes exposições científicas podem ser consideradas como processos de democratização de códigos culturais anteriormente pertencentes às elites ou, ainda, como parte da estratégia de divulgação das instituições envolvidas (SANTOS, 2009).

Apesar da discussão em relação às possíveis intencionalidades de tais mostras, um ponto relevante é o fato de que, ao ultrapassarem barreiras geográficas, as exposições buscam a universalização, seja ela de valores, pressupostos, imagens das ciências, entre outros. É recorrente a ideia de universalidade das ciências, defendendo-a como uma linguagem comum a todos os povos, independentemente de suas especificidades locais.

Este caráter de encobrir pela aparência a essência de certas relações sociais, neste caso o processo de produção da ciência, é advertido por Pesavento (1997, p. 
21), usando a ideia marxiana da mercadoria como fetiche. Ele analisa o início do movimento das exposições universais:

Que outra expressão não teriam as novas máquinas surgidas pela
aplicação da ciência e tecnologia, os rápidos e modernos meios de
comunicação baseados na ferrovia e na navegação a vapor ou os
assombrosos inventos do engenho humano, como o telefone, o
telégrafo, o cinematógrafo, a fotografia? Mercadorias destinadas a
encantar a humanidade, símbolos do progresso técnico-científico dos
"novos tempos", não eram simples produtos à venda, mas
corporificavam ideias que buscavam impor-se com a força de
certezas: o sistema capitalista trouxera o progresso à humanidade, a
máquina era voltada para a satisfação das necessidades humanas, a
ordem burguesa instaurava a sociedade do bem-estar, o futuro era
previsível, o trabalho disciplinado tinha possibilidades redentoras, a
propriedade não era apenas desejável e justa, como era uma meta a
ser alcançada por todos, etc.

Agora projetando tais ideias para a análise das exposições científicas em geral, recorremos aos apontamentos de Souza (2009) que afirma que as exposições se constituem como um loci para construção de significados que contribuem para delinear o entendimento sobre as ciências. $O$ autor aponta ainda que muitas vezes essa construção se dá à margem de determinados conflitos e diferenças que são inerentes a configurações sociopolíticas e culturais em que a prática científica ocorre. Observa-se, assim, uma redução reflexiva das relações sociais por meio de recortes que cumprem um papel ideológico de manutenção de certas relações específicas de poder ou interesses.

Resta-nos, enquanto pesquisadores, questionarmos a quem interessa a manutenção dessa ordem que corrobora com a ideia de uma ciência universal, com representações alegóricas e objetificada como um fetiche pela sociedade.

Ao mesmo tempo em que discutimos as questões locais relativas às Ciências, estamos imersos em um mundo globalizado que busca um processo de homogeneização. Como afirmam Crawford, Shinn e Sörlin (1993), a Ciência pode ser entendida como uma atividade enquadrada por fronteiras, apesar do ethos universalista propagado pelos cientistas. O entendimento da chamada ciência internacional deve ocorrer a partir de uma visão de que a Ciência é uma prática social determinada pelas relações estabelecidas entre pesquisadores de diferentes nações em contextos históricos específicos. Dessa forma, compreende-se que o universalismo científico não corresponderia a uma característica intrínseca à atividade científica, mas seria um valor compartilhado por grupos de cientistas que 
procuram agir no sentido da colaboração internacional em determinados contextos históricos (GÓES FILHO; ARAUJO, 2004). Como aponta Löwy (2000), ao criticar a ideia da universalidade como algo intrínsico às Ciências:

O debate sobre a característica universal da Ciência contém um pressuposto oculto: existe uma ciência única, cuja unicidade e universalidade decorrem automaticamente das propriedades do objeto em estudo, isto é, a natureza. Se a natureza é universal, estável e obedece a leis imutáveis, é evidente que a (boa) ciência é também universal. Estudos históricos recentes, porém, questionaram e problematizaram essa noção de "universalidade da ciência" e mostraram que essa ideia não era de modo algum evidente. Foi preciso um movimento visando a internacionalização da ciência para fazer com que o conjunto de pesquisadores adotassem a ideia de que a ciência deve ultrapassar as fronteiras nacionais (LÖWY, 2000, p.30).

Por outro lado, historiadores das ciências procuraram compreender como os cientistas fabricam o universal através da difusão dos instrumentos e das práticas. ${ }^{16}$ Nesse sentido, Löwy (2000, p. 31) aponta que:

Não é porque são universais que os conhecimentos científicos circulam, eles são universais porque circulam. A circulação e a difusão das práticas, dos instrumentos, dos reagentes e dos indivíduos exige um investimento importante e contínuo de tempo, dinheiro e trabalho. Tomemos um exemplo: para que as leis da gravidade se tornassem válidas para os habitantes da Melanésia, foi preciso construir escolas, enviar professores, imprimir livros, recrutar e formar estudantes; para que elas continuem pertinentes é preciso que o sistema educacional local não se desintegre, que continue mantendo vínculos com os centros de saber do exterior, e que alguns melanésios demonstrem interesse pela física. Esse é o preço da manutenção de uma natureza universal, estável e previsível.

Estudando a representação da ciência em exposições científicas em museus do Brasil e de Portugal, Souza (2011) defendeu a tese de que é possível inserir a imagem científica apresentada em algumas exposições nos quadros da "sociedade do espetáculo". Segundo seus estudos, apesar de muitas vezes essas instituições difundirem um discurso de democratização e diálogo com a sociedade, o que se observa é uma historicidade progressivamente retilínea, com foco nos resultados das

16 Por exemplo, SHAPIN, Steven e SCHAFFER, Simon. Leviathan and the Air Pump... Op. Cit.; SCHAFFER, Simon. The Manufactures of Ohms. In: SCOZZNES, Susan e BUD, Robert. (eds.) Invisible Connections, SPIE Press, 1992, pp.23-56; LATOUR, Bruno. Give me a Laboratory and I will raise the World. In: KNORRCETINA, Karen e MULKAY, Michael. (eds.) Science Observed. Londres, Sage, 1983, pp.141-70; KOHLER, Robert E. The Lords of the Fly. Chicago \& Londres, The University of Chicago Press, 1994. 
Ciências, reafirmando a ideia de ciência universal e homogênea - ou seja, aprocessual - produtora de conhecimentos irrefutavelmente verdadeiros.

Ao ocultar as características sociais das Ciências nas práticas de divulgação científica, corremos o risco de gerar ações reprodutoras de uma lógica espetacular, a complexidade das Ciências - repletas de "conflitos, diferenças e opiniões, características inerentes do social" (LOUREIRO, 2000, p. 2) - é tomada de maneira fragmentada e excludente.

Podemos considerar o movimento das exposições universais e das exposições itinerantes internacionais como iniciativas de divulgação das Ciências e Tecnologias com várias aproximações, mas também com muitos distanciamentos. Por um lado, as exposições universais promoveram processos de internacionalização e universalização, além de terem alimentado e serem alimentadas por novas estratégias desenvolvidas em museus de ciências que, por sua vez, também podem ter influenciado os modos expositivos das atuais exposições internacionais itinerantes. Por outro lado, há um grande distanciamento entre elas quando pensamos nos processos de elaboração do discurso expositivo, na estrutura, nos objetivos, no tempo e na itinerância. As exposições universais são ações políticas, oficializadas, de caráter dito educativo, mas que se constituem como vitrines dos países. Deixam marcos, inclusive arquitetônicos, em cada cidade que as abrigam, têm duração definida e não itineram. Em um contraponto as exposições itinerantes internacionais estão muito mais ligadas à expansão da indústria cultural, como apontado nas seções anteriores.

Apesar de ser difícil analisar a relação entre ambos os movimentos, devido a escassez de produções sobre as exposições internacionais itinerantes, podemos entender que os dois tipos de exposições estão inseridas em processos de internacionalização, que as colocam no rol de iniciativas que devem lidar com fatores decorrentes dessa característica.

Numerosas questões podem emergir dessas colocações e suscitar possibilidades investigativas como: quais os atributos de uma exposição científica que a caracterizam como coerente com as diferenças culturais, sociais, políticas e econômicas das sociedades contemporâneas? Como são estabelecidas as negociações, pelos sujeitos envolvidos nessas exposições, que permitem sua circulação por diferentes países, culturalmente diversos? Como os públicos interpretam tais exposições científicas? Como os valores, ideais e intencionalidades 
são modificados de acordo com os contextos dos países envolvidos? Como as negociações políticas influenciam nesse processo e qual o impacto para a sociedade?

A presente pesquisa pretende fornecer subsídios para essas reflexões, apoiando-se na ideia de que uma atividade de significação de uma exposição científica internacional envolve sujeitos diversos, que possuem convergências e divergências em suas concepções de ciência e de divulgação das Ciências. Assim, o movimento de internacionalização de grandes exposições científicas evidencia, por meio das relações entre os sujeitos, a necessidade de buscar soluções para lidar com a dualidade das questões ligadas ao global $x$ local presentes nestes tipos de ações de divulgação científica. 


\section{CAPÍTULO 2. REFERENCIAL TEÓRICO}

Como apontamos no título desse trabalho, as contradições são eixos estruturantes desta pesquisa, são elas que impulsionam o movimento da atividade humana. Assim sendo, iniciar a apresentação do referencial teórico abordando as raízes dialéticas das contradições tem como objetivo subsidiar as discussões que serão estabelecidas posteriormente, pois se entendemos que o processo de significação de uma exposição científica é algo que acontece atrelado às transformações dos sujeitos e às suas condições materiais concretas, o tema tornase central.

Para além das contradições dialéticas, apresenta-se como essencial no nosso estudo o conceito de atividade humana que está embasada na teoria históricocultural que assume a atividade como unidade de análise. Além disso, baseados na Teoria da Atividade entendemos que são as interações entre os diferentes sistemas de atividades e no sistema de atividade (entre os elementos dele) que permitem a emergência do movimento e das transformações imbricadas na atividade, sendo a reflexão sobre esses elementos essencial para os apontamentos e contribuições que pretendemos fornecer para a área da divulgação científica.

Partindo desses princípios, neste capítulo, pretende-se elucidar o leitor sobre elementos fundamentais para a compreensão da construção do nosso estudo e o embasamento das nossas análises. Temos como foco nessa seção:

1) a abordagem das raízes das contradições dialéticas;

2) As contribuições da perspectiva histórico-cultural e, em especial, da Teoria da Atividade para o desenvolvimento do conceito e do estudo da atividade humana;

3) A relação entre as contradições dialéticas e a atividade humana.

Com isso, deixamos claro que mais do que um referencial teórico, se apresenta também a base do método utilizado nessa pesquisa.

\subsection{AS RAÍZES DIALÉTICAS DAS CONTRADIÇÕES}

A dialética constantemente é foco de diversos estudos e está presente nas ideias de diversos pensadores. Segundo Gadotti (1990), a discussão sobre a dialética esteve fortemente presente entre os filósofos gregos, sendo um importante destaque Heráclito de Efésio (aprox. 540 - 480 a.C.) que a aponta em relação à 
dinamicidade dos fenômenos, ressaltando que tudo aquilo que existe está em constante mudança e que o conflito teria grande participação nesse processo. A falta de estabilidade do ser, portanto, era a explicação para as mudanças que ocorriam.

Como vemos, a questão que deu origem à dialética é a explicação do movimento, da transformação das coisas. Longe de um consenso, a discussão sobre a dinamicidade do ser humano ainda é foco de diversos debates. Historicamente, o pensamento dinâmico do ser tem sido fortemente combatido, principalmente pela metafísica, cuja linha de pensamento defende que os fenômenos devem ser entendidos como imutáveis (LEFEBVRE, 1975). Na visão metafísica do mundo, a qual a dialética se opõe, o universo se apresenta como "um aglomerado de 'coisas' ou 'entidades' distintas, embora relacionadas entre si, detentoras cada qual de uma individualidade própria e exclusiva que independe das demais 'coisas' ou 'entidades'" (PRADO Jr., 1963, p. 10). Tais ideias servem/serviram para garantir os argumentos em prol da divisão da sociedade em classes, sendo elas de interesse, principalmente, das classes dominantes:

\begin{abstract}
A concepção metafísica prevaleceu, ao longo da história, porque correspondia, nas sociedades divididas em classes, aos interesses das classes dominantes, sempre preocupadas em organizar duradouramente o que já está funcionando, sempre interessadas em 'amarrar' bem tanto os valores e conceitos, como as instituições existentes, para impedir que os homens cedam à tentação de querer mudar o regime social vigente (KONDER, 1989, p.19).
\end{abstract}

Diversos pensadores vão olhar para a sociedade em movimento e refletir sobre a dialética, permitindo que ela, subjugada por tempos à metafísica, emerja com outros elementos. O movimento da dialética ao longo da história da humanidade, segundo Gadotti (1990), sempre esteve atrelado às mudanças políticas e sociais das diversas épocas, já que, por vezes, foi por meio da transição entre modelos de sociedades que os filósofos foram aprimorando o entendimento sobre as mudanças do ser. Entre os diversos nomes importantes estão, segundo Konder (1989): Aristóteles (384-322 a.C.), Pascal (1623-1654) e Giambattista Vico (16801744) durante o renascimento; Spinoza (1632-1677) e Denis Diderot (1713-1784) durante o lluminismo; e Jean-Jacques Rousseau (1712-1778).

Entre estes, destaca-se o filósofo alemão Georg Wilhelm Friedrich Hegel (1770- 1831) que apresenta importantes contribuições para o entendimento do método dialético. Em suas reflexões, apontava que a contradição era parte essencial 
do sujeito e da realidade objetiva. Ao refletir sobre o fim da Revolução Francesa e sobre o processo de revolução industrial, Hegel desenvolveu o conceito de trabalho. Segundo Konder (1989, p. 24), Hegel afirmava que "o trabalho é o núcleo a partir do qual podem ser compreendidas as formas complicadas da atividade criadora do sujeito humano". Tal ideia é essencial para entender a proposta hegeliana de superação do homem como ser ligado à natureza e a sua relação com o objeto.

Hegel, apesar de idealista, teve forte influência no desenvolvimento do materialismo dialético. Apoiado em seus estudos, Karl Marx (1818-1883) trouxe a influência materialista para a dialética. Apesar de concordar que o trabalho seria a mola propulsora do desenvolvimento humano, Marx defendia que era necessário olhar para a significação do trabalho físico e material e, somente a partir dessa visão, seria possível perceber o processo de alienação decorrente da apropriação burguesa dos meios de produção e da divisão de classes. "Alguns homens passaram a dispor de meios para explorar o trabalho dos outros, passaram a impor aos trabalhadores condições de trabalho que não eram livremente assumidos por estes. Introduz-se, assim um novo tipo de contradição" (Konder, 1989, p. 29). Como aponta Rodrigues (2013, p. 95):

Para o materialismo dialético, a contradição é o motor para o desenvolvimento da própria realidade e, por consequência, motor do desenvolvimento da teoria. Para o caso da análise marxista do capitalismo, a superação da contradição entre valor de uso e valor de troca vem apenas por meio da revolução proletária, apontada na teoria marxista. Assinala-se que a principal diferença entre a análise marxista e a hegeliana está na análise da totalidade concreta. Enquanto o sistema hegeliano parte de uma contradição abstrata, de um homem abstrato, a análise marxista deve submeter à contradição à concentricidade.

Ao discutir sobre a dialética e o conceito de totalidade concreta, Konder (1989, p. 44) cita Carlos Nelson Coutinho:

A dialética não pensa o todo negando as partes, nem pensa as
partes abstraídas do todo. Ela pensa tanto as contradições entre as
partes (a diferença entre elas: a que faz de uma obra de arte algo
distinto de um panfleto político) como a união entre elas (o que leva a
arte e a política a se relacionarem no seio da sociedade enquanto
totalidade).

Como podemos perceber, o materialismo dialético busca as conexões que existem entre realidades diferentes, e são tais conexões que criam unidades contraditórias. Nessas, a contradição assume papel primordial e, assim, não pode 
ser encarada, pelo viés lógico, como um erro do raciocínio (GORENGER, 1998). Mao Tse Tung resume o pensamento de Marx a respeito do movimento pela oposição dos contrários:

Contrariamente à concepção metafísica do mundo, a concepção materialista-dialética entende que, no estudo do desenvolvimento de um fenômeno, deve partir-se do seu conteúdo interno, das suas relações com os outros fenômenos, quer dizer, deve considerar-se o desenvolvimento dos fenômenos como sendo o seu movimento próprio, necessário, interno, encontrando-se aliás cada fenômeno, no seu movimento, em ligação e interação com os outros fenômenos que o rodeiam. A causa fundamental do desenvolvimento dos fenômenos não é externa, mas interna; ela reside no contraditório do interior dos próprios fenômenos. No interior de todo o fenômeno há contradições, daí o seu movimento e desenvolvimento. O contraditório no seio de cada fenômeno é a causa fundamental do respectivo desenvolvimento (1979, p.32).

Como apontado por LEFEBVRE (1975), em um sentido filosófico a contradição é assumida pela dialética como o elemento que permite o movimento pelo qual os seres existem. A dialética se propõe a ir além da lógica, ocupando e desbravando um campo que a lógica não consegue dominar. Segundo Konder (1989, p. 48), "a lógica, como toda ciência, ocupa-se da realidade apenas em um determinado nível; para alcançar resultados rigorosos, ela limita o seu campo e trata de uma parte da realidade".

Nesta investigação, a compreensão das contradições pelo viés do materialismo dialético é ponto central, pautando-se na ideia de que as tensões acumuladas historicamente são o principal gatilho para o movimento e para a transformação dos sistemas de atividades. É com base na perspectiva materialista dialética que a Teoria Histórico-Cultural da Atividade, essencial nesse trabalho, se constitui e toma forma como um conjunto de ideias que busca entender o homem e suas transformações a partir do cultural e social.

\subsection{A TEORIA HISTÓRICO-CULTURAL COMO BASE PARA A TEORIA DA ATIVIDADE}

A base da psicologia histórico-cultural encontra-se principalmente nos trabalhos de Lev Semionovih Vygotsky (1896-1934). A sua vasta, embora incompleta, obra representa um desafio para qualquer pesquisador, principalmente para os iniciantes. Como aponta Rego (2004), a vida do autor, apesar de curta, foi 
intensa em termos de produção, sendo que muitos escritos não foram sistematizados em livros ou publicações. Soma-se a essa dificuldade, os fatos dos originais terem sido publicados em russo, além da higienização ideológica feita em algumas traduções de suas publicações. A forma dialética do seu pensamento e escrita requer atenção e várias releituras, pois as contradições são expostas e as ideias antagônicas são usadas na síntese do raciocínio.

Vygotsky se baseia na teoria política de Marx para estudar o indivíduo e o ambiente como uma única unidade de análise. Por meio desta formulação, Vygotsky tentou capturar o processo de desenvolvimento dos indivíduos em seus ambientes através de atividades compartilhadas (STETSENKO, 2005). Assim, na teoria vygotskyana, dois conceitos assumem o status de motores do desenvolvimento humano: o social e o cultural. Quando enfatizamos o social na teoria de Vygotsky, é importante esclarecermos o que o caracteriza:

O social de Vygotski está sendo transformado pela ação coletiva dos homens, os quais, abandonando o modo capitalista de produzir a vida, desejam construir uma sociedade comunista. Ele não é apenas o cenário, o meio físico onde se desenrola a ação humana; nem a convivência harmoniosa entre indivíduos; pelo contrário, seu conceito de social está intrinsicamente ligado às condições que conduziram à revolução russa e aos acontecimentos posteriores a ela, bem como ao pensamento marxista que os refletia e replicava (TULESKI, 2008, p.59).

Para compreensão da teoria de Vygotsky é necessário entender a época em que os trabalhos do autor foram desenvolvidos, um cenário marcado pelas lutas presentes na União Soviética entre a Revolução Russa, em 1917, e a década de 1930 (REGO, 2004). Nesse contexto, surge o eixo que guia o pensamento de Vygotsky: "A contradição, intrinsicamente ligada à luta de classes no interior da Rússia e ao período de reconstrução da sociedade, que ora imprimia características burguesas, ora socialistas às relações de produção" (TULESKI, 2008, p.80).

Nessa perspectiva, segundo Lucci (2006), o caminho encontrado por Vygotsky foi elaborar uma base para a psicologia que fornecesse subsídios para o entendimento do recente homem comunista em processo de formação. Essa nova psicologia precisaria avançar em relação ao antagonismo clássico entre materialismo e idealismo, em um momento em que se buscava, por meio do socialismo, enfrentar as relações capitalistas. Essa superação só seria possível se a psicologia tratasse a relação homem e natureza sob a lente de uma perspectiva histórica, na qual o 
homem fosse produto e produtor de si e da própria natureza (TULESKI, 2008).

Sobre a superação da concepção naturalista nos estudos psicológicos, Bernardes (2017, p. 67) aponta que ela ocorre:

[...] por meio dos fundamentos do materialismo dialético e histórico como método de conhecimento na análise das funções psicológicas superiores. Ao considerar o homem como ser social, concebe-se que a natureza que influi sobre a constituição e o desenvolvimento humano não são mais as leis biológicas, mas as condições históricas. De forma dialética, tem-se como desdobramento deste processo a atuação dos homens sobre as novas condições de existência, transformando a natureza externa e se autotransformando. Esta compreensão da relação homem-mundo pauta-se no pensamento de Engels fundamentando a psicologia histórico-cultural.

Ainda sobre as bases psicológicas da teoria vygotskyana, Rodrigues (2013, p. 102) aponta que:

[...] fazer da consciência um objeto de estudo sobre o qual a psicologia poderia se debruçar fez então com que Vygotski iniciasse um programa radicalmente novo. Podemos dizer que obteve sucesso, dadas as terríveis limitações materiais, físicas e políticas (...). A superação das dicotomias na psicologia começa pela criação e desenvolvimento do conceito de mediação dos processos psicológicos. Até então, tanto as perspectivas objetivistas quanto subjetivistas da pesquisa psicológica apoiavam-se fortemente na díade Estímulo- Resposta.

No campo psicológico, Vygotsky (2004, p. 207) coloca que "só podemos compreender cabalmente uma determinada etapa no processo de desenvolvimento - ou, inclusive, o próprio processo - se conhecemos o resultado ao qual se dirige esse desenvolvimento, a forma final que adota e a maneira como o faz". Assim, visase a superação das teorias psicológicas que se fundamentam nas observações e generalizações empíricas pelo plano metodológico que contemple categorias e conceitos que partem de uma fundamentação superior - mais elaborada - para a inferior, do abstrato ao empírico. Resgata-se na psicologia a raiz teóricometodológica que contempla a análise dos fatos da história da ciência - "os acontecimentos concretos, historicamente vivos" (VYGOTSKY, 2004, p. 210).

Temos, na teoria histórico-cultural, segundo Bernardes (2017), as categorias do método que estruturam o movimento de superação das teorias psicológicas com princípios indutivistas e dedutivistas. Tais categorias são: o trabalho, o caráter material da existência humana e a historicidade dos fatos. Para a autora:

O trabalho, entendido como atividade adequada a um fim, é 
considerado o que nos faz humanos, uma vez que pelas necessidades emergentes da realidade, o homem define objetivos, planeja ações para realizá-los e transforma a natureza, ao mesmo tempo em que se autotransforma, humanizando-se. [...] O caráter material da existência humana é a categoria que explica o modo de produção e de constituição do processo de humanização. Assim sendo, entende-se ser por meio da produção que se definem as bases das relações sociais. [...] O desenvolvimento da sociedade na vida concreta produz mudanças na consciência e na conduta humana, fato que nos leva a considerar a categoria historicidade como a dimensão essencial da formação do psiquismo humano. (Bernardes, 2017, p. 65).

Kozulin (1986) aponta que Vygotsky encontrou na filosofia marxista e hegeliana uma teoria social para a atividade humana, em oposição ao naturalismo e à receptividade passiva da tradição empirista:

De acordo com Vygotsky, o comportamento humano e a mente podem ser considerados mais em termos de ações intencionais e significativas, do que como reações biológicas, adaptativas. Objetos da experiência humana - e, portanto, objetos em experimentos psicológicos - são elementos socialmente e culturalmente significativos e não somente estímulos abstratos (KOZULIN, 1986, p. 266, tradução nossa).

Nesse sentido, podemos entender que o sujeito age a partir de uma atividade direcionada a um objeto, sendo esse processo mediado por instrumentos (VYGOTSKY, 1978). Ao inserir o instrumento na relação sujeito - objeto, Vygotsky cria duas novas ligações que implica que o homem pode controlar e modificar o seu comportamento a partir de elementos externos. Esse novo entendimento da atividade humana "recria e reconstrói por completo toda a estrutura do comportamento, do mesmo modo que o instrumento técnico recria totalmente o sistema de operações de trabalho" (VIGOTSKI, 2005, p. 97). A partir da Figura 3 abaixo é possível representar essa ideia.

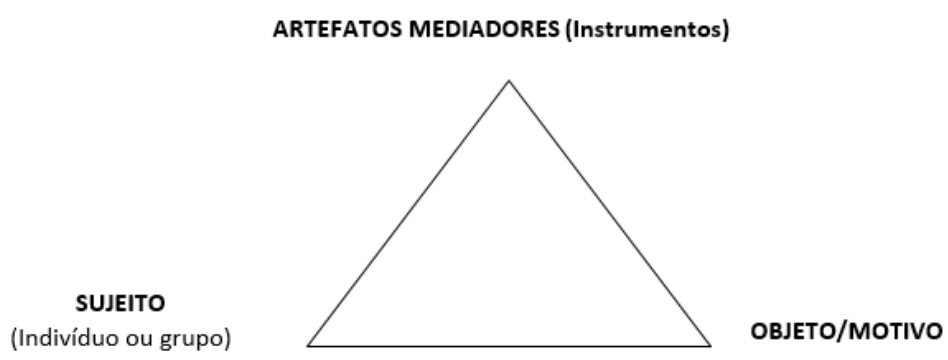

Figura 3 - Esquema do comportamento dirigido a um objeto através da mediação. Fonte: Adaptado Vygotsky (1978, p. 40). 
Para exemplificar essa proposta, podemos pensar em um visitante de um museu (Sujeito) que tem como objeto, inicialmente, os conceitos e práticas científicos e que, por meio da mediação dos objetos museais (instrumentos), consegue satisfazer sua necessidade de aprender sobre as Ciências. Nessa ação sobre o mundo, transforma os objetos e os instrumentos, bem como a si mesmo (BIZERRA, 2009).

Por fim, as ideias elaboradas por Vygotsky têm como compromisso buscar uma nova concepção de realidade e de homem, rompendo com as correntes de pensamento vigentes em sua época. O pensamento vygotskyano serviu e ainda serve de base para pesquisadores de diversas linhas e áreas de pesquisa. Entre os desdobramentos do trabalho desse autor, encontra-se a Teoria da Atividade, que abordaremos a seguir.

\subsection{A TEORIA DA ATIVIDADE}

As raízes da Teoria da Atividade são colocadas no século XIX, com os trabalhos de Kant, Hegel, Marx e Engels, mas é tida como fortalecida nos anos $20 \mathrm{e}$ 30 do século seguinte (ROGERS; SCAIFE, 1997). Os nomes usualmente associados a esse desenvolvimento, como A. N. Leontiev, A. R. Luria e S. L. Rubinstein, enfatizaram a importância da atividade no desenvolvimento do psiquismo humano, já presente nas ideias de Vygotsky (BANNON, 1997; ENGESTRÖM, 1999; ROGERS; SCAIFE, 1997; WAITE, 2003, apud BIZERRA, 2009).

Hoje, a Teoria da Atividade corresponde a uma perspectiva de investigação e prática comumente aceita em diversos países, sendo utilizada na teorização e nas pesquisas ligadas às práticas culturais (ENGESTRÖM; MIETTINEN, 1999).

\subsubsection{As contribuições de Aleksei Nikolaevich Leontiev (1903-1979)}

Vygotsky, em seus estudos, já preconizava a noção de unidade de análise que se contrapõe à fragmentação da metafísica. Para ele, era necessário cruzar o método e o conteúdo concreto da análise. Leontiev, em seus estudos, incorpora tais ideias sobre o desenvolvimento do psiquismo humano, afirmando que a unidade para analisar o sujeito deve ser a sua atividade, sendo a atividade social a base da 
construção do psiquismo:

Para descobrir estas características psicológicas da consciência, devemos absolutamente rejeitar as concepções metafísicas que isolam a consciência da vida real. Devemos, pelo contrário, estudar como a consciência do homem depende do seu modo de vida humano, da sua existência. Isto significa que devemos estudar como se formam as relações vitais do homem em tais ou tais condições sociais históricas e que estrutura particular engendra dadas relações. Devemos em seguida estudar como a estrutura da consciência do homem se transforma com a estrutura da sua atividade. Determinar os caracteres da estrutura interna da consciência é caracterizá-la psicologicamente (LEONTIEV, 1978, p. 92).

A atividade é considerada, por esse referencial, como parte essencial e indivisível da vida social e inclui objetivos não somente físicos, mas também mentais. Portanto, não é uma entidade isolada. Há um agente, um sujeito que atua individual ou coletivamente e direciona sua atividade a algo. Há objetos com as quais o sujeito interage e é a atividade que medeia essa interação (BANNON, 1997).

A análise da atividade pode ser entendida como base para a compreensão da consciência. $O$ estudo da composição estrutural da atividade permite compreender as transformações da estrutura da consciência (LEONTIEV, 1978). A consciência, ou o reflexo psíquico, não é pré-concebida, mas pode ser entendida como resultante das relações do sujeito com a realidade material que o cerca, da atividade do sujeito nesse cenário. A atividade é, portanto, a transformação do mundo pelos sujeitos, que ao transformarem a realidade, transformam-se a si mesmos.

Abordando a identificação das atividades, Leontiev aponta que o objeto da atividade se relaciona com o motivo e que a análise dele permite diferenciar as atividades, pois é o objeto que dá um direcionamento à atividade.

O motivo é a força diretiva da atividade, ou em outras palavras é em torno do motivo que a atividade vai se estruturar e se organizar. Pode-se perguntar: $O$ que se quer ao fim de tudo isso? $O$ que se quer transformar? Que resultados buscam obter? etc. A resposta sobre o sentido, o sentido da atividade, a que se direciona uma determinada atividade será encontrada no motivo (RODRIGUES, 2013, p. 124).

Podemos entender o motivo como um estímulo que direciona a atividade em busca de um fim determinado, este é o objeto que está relacionado às necessidades do sujeito.

O conceito de objeto também precisa ser clarificado e, assim, temos que o que compõe o objeto são "as operações de trabalho historicamente elaboradas" 
(LEONTIEV, 1978, p. 268), portanto, nessa relação com objeto, o indivíduo incorpora a atividade mental e física nele presente, o que exige adequação das funções psíquicas.

Sobre essa relação entre objetos, motivos e necessidades, Asbahr (2005, p.109) aponta que:

[...] no decorrer da história da humanidade, os homens construíram infindáveis objetos para satisfazer suas necessidades. Ao fazê-lo, produziram não só objetos, mas também novas necessidades e, com isso, novas atividades. Superaram as necessidades biológicas, características do reino animal, e construíram a humanidade, reino das necessidades espirituais humano-genéricas.

Segundo Grassi (2017), a atividade é o elo que permite que o ser humano estabeleça relações com o mundo. Podemos, portanto, estabelecer que a relação entre o objetivo e o subjetivo expressa o nexo entre a consciência e a atividade, pois é na ação com o objeto que 0 indivíduo o transforma ao mesmo tempo que transforma a si próprio. A consciência não só permite refletir essa relação com o mundo, mas também diz sobre as atitudes, necessidades, motivações e inclinações do sujeito perante a realidade.

A análise da complexidade de uma atividade nos revela que há uma cadeia de ações que permite que ela seja realizada. "A atividade humana não existe se não na forma de ações ou cadeia de ações" (LEONTIEV, 2009, p. 100). Esses elementos da atividade geralmente possuem um tempo menor e são direcionadas a uma meta específica, embora uma mesma ação possa se inserir em atividades diferentes.

As ações têm fins próprios conscientes, porém, à medida que elas são realizadas e dependendo das condições presentes, podem passar por um processo de operacionalização, deixando de ter um fim próprio e se tornando uma operação. Assim, a partir da concepção de Leontiev (1978), entende-se por operações as formas escolhidas para se realizar as ações, ou seja, as condições usadas para se atingir um fim, as quais se tornam automáticas e mecânicas de tal forma que não são necessárias reflexões na realização (Figura 4). 


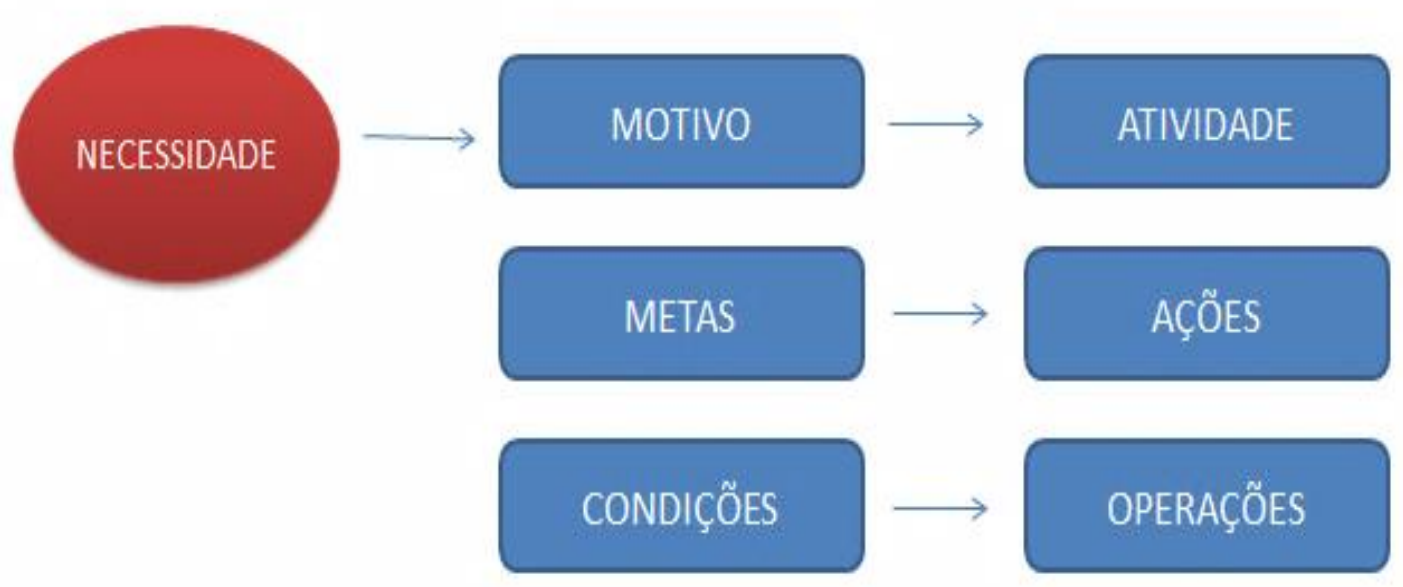

Figura 4 - Níveis estruturais da atividade humana. Fonte: Adaptado de Leontiev (2004).

Esse processo de passagem de ações a operações permite a ampliação da atividade, porém, mudadas as circunstâncias, uma operação pode voltar a ser uma ação ou mesmo uma ação pode assumir o papel de uma atividade ao serem criados motivos próprios.

Leontiev (2009) afirma que a atividade é "[...] um sistema altamente dinâmico que é caracterizado por constantes transformações. A atividade pode perder o motivo que a evocou, e nesse caso pode se tornar uma ação que estabelece, talvez, uma relação diferente com o mundo." (p. 8, tradução nossa). Assim, devemos entender a complexidade da atividade humana em seu dinamismo e não como padrões fixos.

A explicação de Cenci (2018, p. 933-934) pode ilustrar a discussão sobre a dinamicidade dos elementos da atividade:

Para definir a atividade, é preciso esclarecer seu motivo, seu objeto. A partir daí, podem-se estabelecer as ações e as operações. A atividade é entendida como o sistema amplo. Contudo, ela só pode existir em forma de grupo de ações - dirigidas para objetivos pontuais, com início e fim definidos. As ações, por sua vez, dependem dos processos já automatizados, as operações. Esses três níveis - atividade, ação, operação - são intercambiantes, conforme se alteram os motivos e a tomada de consciência sobre eles. Por exemplo, você, que está lendo este texto, poderá ter como atividade a leitura em si ou poderá estar lendo por outro motivo, como a utilização de seu conteúdo em um texto que está escrevendo. No primeiro caso, a leitura é atividade, no segundo, é ação, que compõe outra atividade, isto é, a produção de um texto. 
Contudo, não se devem tomar esses níveis como estanques: você pode começar a ler o texto com o objetivo de utilizá-lo em seu trabalho escrito e, no decorrer da leitura, dedicar-se à sua compreensão, deixando de lado o fim que o levou a empreender tal ação. Assim, o que inicialmente era ação, transformou-se em atividade. $O$ oposto também acontece: uma atividade transforma-se em ação, quando a primeira passa a ser subordinada à segunda. Voltando ao exemplo: o texto que você precisa escrever deixa de ser visto como atividade se ele é percebido apenas como requisito para aprovação numa disciplina. Nesse caso, a aprovação torna-se a atividade e a escrita do trabalho torna-se ação. No mesmo exemplo, para ler o texto, é preciso que você saiba decodificar os símbolos gráficos impressos, coisa que você faz e nem percebe (não é um processo consciente). Isso se caracteriza como uma operação, pois esse processo de decodificação das letras já está automatizado. Porém, em uma criança que está aprendendo a ler, o mesmo processo constitui-se em uma atividade ou uma ação - atividade, se o motivo for aprender a ler em si, e ação, se o motivo de aprender a ler for conseguir ser aprovada para o próximo ano. A análise de uma atividade requer que se capture o seu motivo, pois, conforme se pode ver no exemplo recém-citado, uma mesma "coisa" pode ser atividade, ação ou operação. Apenas pela aparência não é possível apreender a essência de uma atividade.

Podemos ver em Leontiev uma ampliação dos estudos de Vygotsky ao enfocar a atividade como social e imersa no coletivo. Como aponta Daniels (2011), podemos notar em seus estudos a ênfase da mediação em seu contexto cultural, incorporando as relações sociais e as regras como elementos centrais da atividade. Em Leontiev, vemos também que diversas atividades estão imbricadas no seio da sociedade, criando uma complexa rede de possibilidades de interações.

\subsubsection{Engeström e complexificação da atividade humana}

Yrjö Engeström (p. e., 1987, 1999, 2001), pesquisador finlandês coordenador do CRADLE (Center for Research on Activity, Development and Learning), tem sido reconhecido como uma importante referência para ampliação dos estudos que abrangem a Teroria da Atividade (DANIELS, 2003). Engeström ressalta que as ações individuais ou coletivas serão compreendidas quando interpretadas à luz de sistemas de atividades e considera que estes sistemas se constituem como as unidades de análise para pesquisas que se inserem na perspectiva teórica da Teoria da Atividade.

Esses sistemas de atividade, conforme Engeström (1999), a partir de Leontiev, incluem além do objeto, do sujeito e dos artefatos mediadores (simbólicos 
ou materiais), as regras, as comunidades e a divisão de trabalho, relacionados dinamicamente entre si. "O relacionamento entre sujeito e objeto é mediado pela 'ferramenta', o relacionamento entre sujeito e comunidade é mediado pela 'regra', e o relacionamento entre objeto e comunidade é mediado pela 'divisão social do trabalho" (KUUTTI, 1996, p. 28). Para Lemos e colaboradores:

Sistemas de atividade são orientados a um objeto, que são coletivos e têm uma duração de longo prazo. Esses sistemas de atividade são geralmente organizados, tomam forma de organizações, naturalmente não somente organizações formais, mas, também, organizações informais, tais como comunidades e famílias. Esses sistemas coletivos de atividade podem ser modelados e analisados com a ajuda de modelos básicos, tais como o já consagrado modelo dos triângulos da atividade (LEMOS et. al., 2013, p. 717).

A expansão do triângulo elaborado por Vygotsky (Figura 5), já presente de forma não esquemática nos estudos do Leontiev, tem como objetivo evidenciar os elementos sociais e coletivos presentes nas atividades.

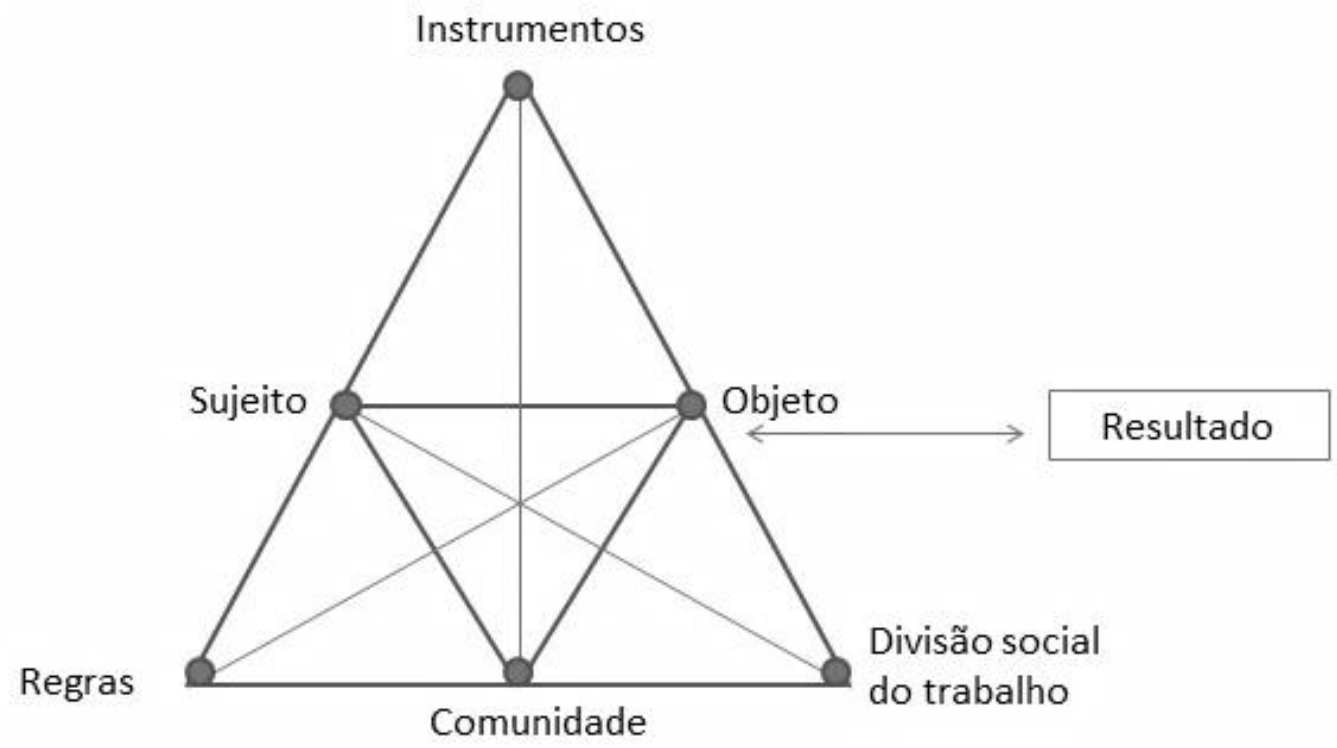

Figura 5 - Estrutura da atividade humana. Fonte: Engeström (1987).

Como propõe Liberali (2009, p.19), podemos entender a atividade social como constituída por "agentes (sujeito) que percebem suas necessidades, são motivados por um propósito (objeto), o qual é mediado por artefatos (instrumentos) por meio de uma relação entre indivíduos (comunidade), que se constitui por regras e por divisão de trabalho".

Os componentes de uma atividade podem ser compreendidos conforme 0 
quadro abaixo (Quadro 1):

QUADRO 1. Componente da Atividade (LIBERALI, 2009, p. 12)

\begin{tabular}{|c|c|}
\hline Sujeitos & $\begin{array}{l}\text { São aqueles que agem em relação ao motivo e } \\
\text { realizam a atividade. }\end{array}$ \\
\hline Comunidades & $\begin{array}{l}\text { São aqueles que agem em relação ao motivo e } \\
\text { realizam a atividade. }\end{array}$ \\
\hline Divisão de trabalho & $\begin{array}{l}\text { É aquela em que as ações intermediárias são } \\
\text { realizadas pela participação individual na atividade, } \\
\text { mas que não alcançam independentemente a } \\
\text { satisfação da necessidade dos participantes. São as } \\
\text { tarefas e funções de cada um dos sujeitos envolvidos } \\
\text { na mesma atividade. }\end{array}$ \\
\hline Objeto & $\begin{array}{l}\text { É aquilo que satisfará a necessidade, o objeto } \\
\text { desejado. Tem caráter dinâmico, transformando-se } \\
\text { com o desenvolvimento da atividade. Tratou-se da } \\
\text { articulação entre o idealizado, o sonhado e o desejado, } \\
\text { que se transforma no objeto final ou no produto. }\end{array}$ \\
\hline Regras & Normas explícitas ou implícitas da comunidade. \\
\hline Instrumentos & $\begin{array}{l}\text { Meios de modificar a natureza para alcançar o objeto } \\
\text { idealizado. Passíveis de serem controlados pelo seu } \\
\text { usuário revelam a decisão tomada pelo sujeito; usados } \\
\text { para o alcance de fim predefinido (instrumento para o } \\
\text { resultado) ou constituído no processo da atividade } \\
\text { (instrumento e resultado). }\end{array}$ \\
\hline
\end{tabular}

Com o que aqui foi exposto, entendemos que a análise do estudo de caso foco desse trabalho é um campo frutífero, pois este referencial teórico focaliza:

O estudo das atividades em que os sujeitos estão em interação com outros em contextos culturais determinados e historicamente dependentes. [...]. Para que esse conjunto de ações possa ser compreendido como uma atividade, é preciso que os sujeitos nela atuantes estejam dirigidos a um fim específico, definido a partir de uma necessidade percebida. Em outras palavras, uma atividade é realizada por sujeitos que se propõem a atuar coletivamente para o alcance de objetos compartilhados que satisfaçam, mesmo que parcialmente, suas necessidades particulares (LIBERALI, 2009, p. 12)

Entendemos que essa rede complexa que foi formada para a concretização da vinda e exibição do Túnel da Ciência 3.0 se constitui, na perspectiva teórica que propomos para a análise, como um conjunto de atividades que compartilham o 
mesmo objeto, permeada por tensões e contradições, o que implica em não olharmos apenas para um simples sistema de atividade, mas para a interrelação entre os múltiplos sistemas de atividade que, de alguma forma, se relacionam com um mesmo objeto.

Como ressalta Bizerra (2009), são as tensões e contradições presentes nesses sistemas e nas suas relações, acentuadas pelas transformações contínuas dos elementos constituintes do sistema, a força motriz para a mudança e o desenvolvimento.

Engeström (2001), afirma que é importante pensar as atividades como redes complexas de interação. Esses pontos de interação podem ocorrer tanto entre um elemento de uma atividade (que pode ser o objeto de um ou outro sistema), como a partir de objetos compartilhados (Figura 6):

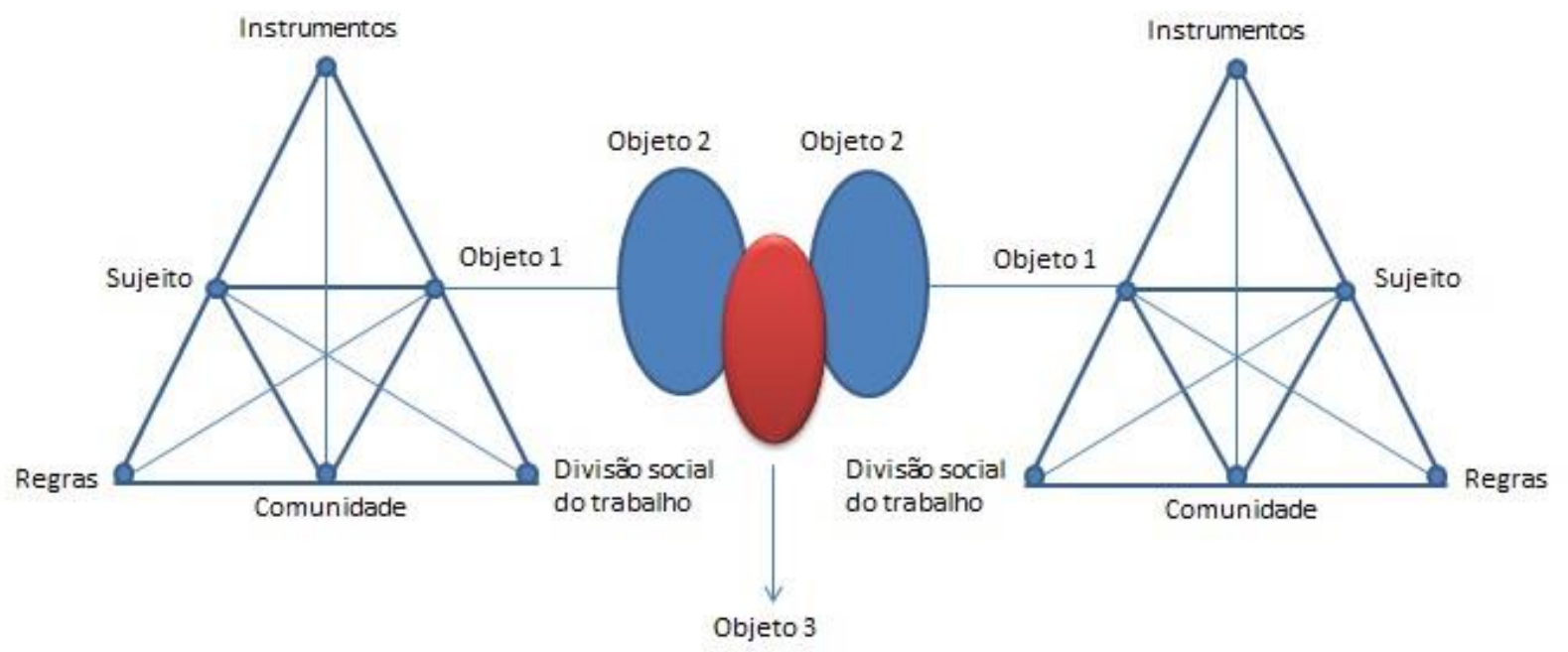

Figura 6 - Interação de duas atividades compartilhando o mesmo objeto. Fonte: adaptado de Engeström (2001).

Podemos entender que os sistemas de atividades não se constituem de maneira linear e simplista, essa construção está em constantes modificações e envolve diferentes participantes, não ocorrendo sem a presença de conflitos:

A constituição de uma atividade envolve negociações, orquestração e pela luta constante entre diferentes metas e perspectivas de seus participantes. O objeto e o motivo de uma atividade coletiva são algo como um mosaico em constante evolução, um padrão que nunca está inteiramente finalizado (ENGESTRÖM, 1999, p. 382).

A transformação implica em uma modificação geral do sistema de atividades. 
À medida que o processo de transformação do objeto acontece, os outros elementos sistêmicos precisam se adaptar às novas contradições que engendram o sistema como um todo (RODRIGUES, 2013).

Essas contradições não devem ser reduzidas a problemas ou conflitos. São tensões acumuladas historicamente, em um sistema de atividades ou entre eles, que podem constituir-se somente como conflitos ou renovar possibilidades de mudança da atividade (BIZERRA, 2009). As contradições são partes integrantes e importantes para o entendimento das atividades em movimento.

A importância de olhar e analisar as contradições do sistema é que a partir de sua superação é possível que os sistemas de atividade mudem, permitindo a sua expansão. Engeström (1999) explora essa questão ao sugerir a ocorrência de ciclos expansivos que representam um processo de interiorização e exteriorização ou o percurso pelo qual a atividade se transforma. Podemos entender a interiorização como reprodução da cultura e a exteriorização como a produção de novos artefatos. Esse caminho é feito por meio de várias etapas e muitas vezes esses ciclos permanecem incompletos.

Sobre o processo de internalização e externalização, Engeström (1999) aponta que:

Os ciclos expansivos iniciam a partir de uma ênfase quase que exclusiva na internalização, socialização e treinamento dos novatos para que os mesmos se tornem membros competentes da atividade que rotineiramente segue o seu curso. A externalização ocorre primeiramente como inovações individuais discretas. Com o aumento das rupturas e contradições da atividade, o processo de internalização assume a forma de reflexão crítica por parte dos indivíduos - e a externalização, a busca por soluções, aumenta. A externalização atinge o seu pico quando um novo modelo de atividade é construído e implantado. Com a estabilização do novo modelo, a internalização das suas formas e meios torna-se novamente a forma dominante de aprendizagem e desenvolvimento (p. 33-34, tradução nossa).

O tempo para complemento de um ciclo é variável. Em ciclos maiores, o que se observa é o encadeamento de vários ciclos menores. Entende-se que a consolidação de uma nova prática é o início de um novo ciclo. Desse modo, os ciclos de larga escala envolvem inúmeros ciclos pequenos (ENGESTRÖM, 2010).

Daniels (2011) destaca cinco princípios da Teoria da Atividade proposta por Engeström. O primeiro é que a unidade primordial de análise é um sistema de atividade coletivo, mediado por artefato e orientado por objeto, visto em suas 
relações de rede com outros sistemas de atividade. O segundo princípio é a multiplicidade de vozes dos sistemas de atividade, que são os múltiplos pontos de vista, tradições e interesses. O terceiro princípio é a historicidade. Os sistemas de atividade tomam forma e são transformados em extensos períodos de tempo. O quarto princípio é o papel central das contradições como fontes de mudança e desenvolvimento. Por fim, o quinto princípio é a possibilidade de transformações expansivas ou ciclos relativamente longos de transformações qualitativas.

Em síntese, a superação das contradições presentes nas atividades permite que os sistemas de atividades se reorganizem e que os ciclos expansivos de aprendizagem possam avançar. Apesar disso, é importante lembrar que a emergência dessas reorganizações é constante, assim como o surgimento de novas contradições. Se entendemos como essencial compreender os conteúdos das contradições presentes nesses sistemas de atividade é necessário pensar como podemos identificá-las.

\subsection{A CONTRADIÇÃO COMO MOTOR DA ATIVIDADE HUMANA}

O ponto de partida da Teoria da Atividade é a atividade, com seu aspecto criativo e transformador, vindo de suas contradições internas e movimento. Geralmente, o termo "contradição" é utilizado de forma aleatória e equiparado a uma série de outros termos e, poucas vezes, é teoricamente definido na perspectiva das mudanças organizacionais ou individuais.

Segundo Wilde (1989, p. 102), contradições dialéticas são diferentes das contradições descritas no princípio da não-contradição, que afirma simplesmente que "duas proposições contraditórias não podem ser ambas verdadeiras". A dialética trata de sistemas em movimento através do tempo. Os elementos de uma contradição dialética relacionam-se entre si dentro da estrutura do movimento, historicamente. A contradição dialética refere-se a uma unidade de opostos, forças opostas ou tendências dentro de um sistema dinâmico. Em seus trabalhos, Engeström (2008) chama atenção para os distúrbios que aparecem nos sistemas de atividades que podem indicar a presença de contradições:

Eles [os distúrbios] podem ser interpretados como sintomas ou manifestações do desenvolvimento histórico da contradição interna em um dado sistema de atividade. Tal contradição sistemática é a chave para compreender a fonte dos problemas assim como os 
potenciais para inovação e desenvolvimento da atividade (ENGESTRÖM, 2008, p. 27).

Segundo o mesmo autor, no ciclo expansivo, as contradições emergem em quatro níveis como ilustrado na figura 7. O primeiro está relacionado ao que Marx apontava sobre a tensão fundamental do capitalismo que reside no valor de troca e de uso e, para o pesquisador finlandês, isso pode ser identificado no sistema de atividade dentro de cada nó. As contradições secundárias são identificadas entre os nós constituintes da atividade central. Esse nível de contradições aparece, geralmente, quando novos elementos externos ao sistema são incorporados. Já as contradições terciárias estão relacionadas ao aparecimento de novos motivos ou objetos, podendo levar a novas atividades. As contradições quaternárias acontecem entre a atividade central e as periféricas, ou seja, no nível hierárquico mais amplo do sistema de atividades.

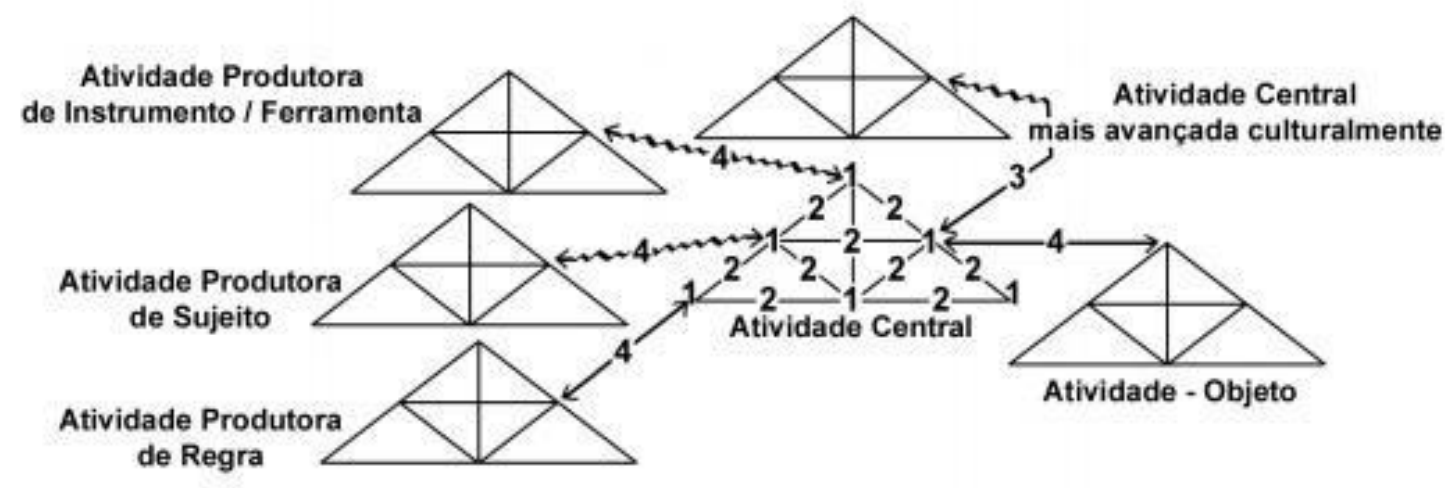

Figura 7 - Os quatro níveis de contradições dentro do sistema de atividade humana. Fonte: Engeström (1987).

Como contradições são fenômenos historicamente emergentes e sistêmicos, em estudos empíricos, não temos acesso direto a elas. As contradições devem ser abordadas, nesse sentido, por meio de suas manifestações. Frente a esse pressuposto teórico, Engeström e Sannino (2011) elaboraram um quadro metodológico para conceituação e identificação das contradições nos discursos.

Para os autores, é possível identificar diferentes tipos de manifestações discursivas de contradições: dilemas, conflitos, conflitos críticos e duplos vínculos 
(ENGESTRÖM E SANNINO, 2011, tradução nossa). ${ }^{17}$

Dilemas são ideologicamente criados e correspondem a produtos da história. Nesse sentido, um dilema "dificilmente pode ser universal" (BILLIG et al., 1988, p. 149). Para Engeström e Sannino (2011), o dilema é uma expressão ou troca de avaliações incompatíveis, quer entre pessoas ou dentro do discurso de uma única pessoa. É comumente expresso na forma de hesitações, com o uso de termos como "por um lado, por outro lado" e "sim, mas". Em um discurso em vão, não direcionado, dilemas normalmente são reproduzidos, sem uma proposta de solução, e muitas vezes com a ajuda de negação ou reformulação.

Os conflitos assumem a forma de resistência, desacordo, discussão e crítica. Dreu e Van de Vliert (1997, p.1, tradução nossa) definem que "os conflitos ocorrem quando um indivíduo ou um grupo se sente afetado negativamente por outro indivíduo ou grupo, por exemplo, por causa de uma divergência percebida de interesses, ou por causa de um comportamento incompatível do outro". As expressões comuns de conflito no discurso são "não", "eu discordo" e "isso não é verdade" (GRIMSHAW, 1990). Em particular, a negação ou rejeição com um "não" é uma poderosa indicação de potencial de um conflito (LITOWITZ, 1997)

Já os conflitos críticos são situações em que as pessoas enfrentam dúvidas internas que as paralisam frente às motivações contraditórias. Envolvem normalmente sentimentos de ser violado ou culpado, muitas vezes de forma silenciada (SANNINO, 2008). Aparecem a partir de um discurso carregado emocionalmente e moralmente, com uma estrutura narrativa com emprego de metáforas fortes.

Duplo-vínculos são processos em que os atores enfrentam repetidamente alternativas urgentes e igualmente inaceitáveis em seu sistema de atividade e se veem sem saída. No discurso, aparecem a partir da expressão da necessidade de fazer alguma coisa e, ao mesmo tempo, a impossibilidade de percepção de uma ação, como em "O que podemos fazer?". Geralmente envolve uma tentativa de transição entre o "eu" individual para o coletivo "nós", como "devemos", "nós temos que", carregado com um sentido de urgência. São representados, ainda, pelas

17 No original são utilizados os seguintes termos respectivamente: "dilemmas, conflicts, critical conflicts e double binds". 
situações contraditórias em que o sujeito se manifesta de uma forma e age diferentemente.

Esse arcabouço teórico da teoria histórico-cultural da Atividade será utilizado como base para a identificação dos sistemas de atividades e de seus movimentos a partir da superação das contradições, essas identificadas a partir da ideia do materialismo dialético.

Espera-se compreender as negociações em curso ao se trazer uma exposição internacional para o Brasil a partir da superação (ou não) das contradições pelos sujeitos envolvidos.

Dessa forma, delimitamos a pesquisa a partir das seguintes questões:

1) Pensando nos diversos atores envolvidos, quais os sistemas de atividades presentes e como eles se relacionam?

2) Quais são as tensões e os conflitos presentes no processo de internacionalização de uma exposição científica?

3) Quais as contradições presentes nessas atividades e como elas são superadas pelos participantes?

4) Quais os conteúdos das contradições identificadas no caso em questão?

5) Como esse quadro de contradições pode contribuir para uma divulgação científica que dialogue com as especificidades locais? 


\section{CAPÍTULO 3 - METODOLOGIA DE PESQUISA}

Percebe-se que a adoção do escopo teórico da Teoria da Atividade se constitui por si só como um desafio que nos coloca, enquanto grupo de pesquisadores, frente a uma problemática que envolve as escolhas metodológicas que possam ser fiéis aos pressupostos da Teoria Histórico-Cultural da Atividade.

A metodologia da pesquisa vai além de uma mera obtenção e organização dos dados, ela revela as opções epistemológicas do pesquisador. Rubinstein (1978) ressalta a importância de colocar em evidência as leis específicas básicas dos fenômenos estudados, sendo este o objetivo principal de qualquer teoria. Acrescenta, ainda, que os métodos de pesquisa, como os de toda pesquisa científica, estão determinados sempre pela concepção teórica de base, que serve de orientação, direção e guia.

Durante os diversos percursos que compõem a pesquisa, é exigido do pesquisador uma tomada de decisão sobre como responder às perguntas propostas a partir do contexto teórico da investigação, guiado por seus objetivos. Tal tarefa não é linear e nem trivial. Como já apontava Vygotsky, "o método, ou seja, o caminho seguido, é visto como um meio de cognição: mas o método é determinado em todos os seus pontos pelo objetivo que conduz. Por isso, a prática reestrutura toda a metodologia da ciência" (2004, p. 346).

$O$ percurso apresentado a seguir representa as idas e vindas que foram remodelando a pesquisa e o ser pesquisador. Buscamos nas próximas seções descrever e refletir sobre as opções metodológicas que julgamos adequadas para o desenvolvimento dessa tese de doutorado.

Saliento que a pesquisa foi cadastrada na Plataforma Brasil, Certificado de Apresentação para Apreciação Ética número 86548818.5.0000.5464, tendo obtido a aprovação do Comitê de Ética do Instituto de Biociências da Universidade de São Paulo (USP).

\subsection{DEFINIÇÕES DA PESQUISA}

Levando em consideração as características da nossa pesquisa, entendemos que a perspectiva metodológica que se aproxima dos objetivos propostos é a abordagem qualitativa. Entendemos que existe um grande debate sobre as 
características da pesquisa qualitativa (KIRSCHBAUM, 2013; LEE e WALLERSTEIN, 2000; DENZIN e LINCOLN, 2005) e, somado a isso, há a discussão sobre a dispensa da adoção e até mesmo sobre a incongruência das abordagens qualitativas no âmbito de vinculações com o materialismo histórico dialético, assumindo-o como detentor de uma epistemologia suficiente para o fazer científico (MARTINS, 2006). Tais discussões estão sendo cada vez mais amadurecidas e não cabem do escopo dessa pesquisa. Assim, optamos por não abordar tais polêmicas, mas apresentarmos alguns pontos de aproximação entre nossa pesquisa e a perspectiva qualitativa.

Diversos argumentos podem ser usados para situar um estudo no âmbito qualitativo, como: os métodos de coleta e a possível aproximação do pesquisador com o objeto de estudo (LUDKE e ANDRÉ, 1986); seu caráter exploratório e descritivo (TRIVIÑOS, 2008); a possibilidade de estudar processos que não podem ser examinados ou medidos experimentalmente em termos de quantidade (DENZIN e LINCOLN, 2006), entre outros. Porém, é importante ressaltar que "o que dá o caráter qualitativo não é necessariamente o recurso de que se faz uso, mas o referencial teórico-metodológico eleito para a construção do objeto de pesquisa e para a análise do material coletado no trabalho de campo" (DUARTE, 2004, p. 215).

Segundo Minayo (2000, p. 48), as pesquisas qualitativas buscam "incorporar a questão do significado e da intencionalidade como inerentes aos atos, às relações, e às estruturas sociais, sendo essas últimas tomadas tanto no seu advento quanto na sua transformação, como construções humanas significativas". Nesse sentido, segundo González Rey (2005), a pesquisa qualitativa, por ele abordada a partir da epistemologia qualitativa orientada pela perspectiva histórico-cultural, é uma das possibilidades, dentre outras, de explorar os complexos processos de construção do conhecimento sobre a subjetividade humana. Acrescenta, ainda, que não significa excluir os dados quantitativos e não se limita somente à escolha do tipo de instrumentos de coleta de dados, ela também, "se caracteriza pelo seu caráter construtivo-interpretativo, dialógico e pela sua atenção ao estudo dos casos singulares" (GONZÁLEZ REY, 2001, p. 4).

Situamos então nosso estudo a partir de um diálogo com a abordagem qualitativa ancorada na Teoria Histórico-Cultural da Atividade, tendo o materialismo histórico-dialético como pano de fundo, expressando em seus métodos e arcabouço conceitual as marcas de sua filiação dialética. 
O objetivo dos próximos tópicos é reconstituir o caminho metodológico, porém, adianto ao leitor que tal percurso apesar de ser apresentado de forma linear não tomou esta característica durante seu desenvolvimento. Para isso, discorreremos sobre o nosso local de estudo, os participantes da pesquisa e 0 processo de levantamento e análise dos dados.

\subsection{O ESTUDO DE CASO COMO ABORDAGEM METODOLÓGICA}

Como já citado, uma das escolhas metodológicas foi conduzir esta investigação a partir de um estudo de caso. Acreditamos que o contexto que envolve o processo de vinda da exposição somado aos objetivos e perguntas de pesquisa permitem-nos enquadrá-lo nas prerrogativas desse tipo de investigação. Como afirmam Lüdke e André (1986), a investigação qualitativa pode assumir várias formas, sendo o estudo de caso uma delas.

Segundo Stake (2000, p. 436), o estudo de caso como estratégia de investigação é bastante difundido nas pesquisas sociais, porém esse autor alerta sobre o fato de que "nem tudo pode ser considerado um caso". Acrescenta ainda que é importante que o pesquisador tenha em mente os critérios norteadores que 0 guiam em sua investigação como estudo de caso.

Isto dito, trago para essa seção alguns autores e ideias que permitiram estruturar o presente estudo como um caso.

Lüdke e André (1986) referem que o estudo de caso é único, particular, distinto dos outros, mas que, posteriormente, podem emergir semelhanças ou paralelos com outros casos ou situações. Para as autoras, podemos apontar sete características relacionadas aos estudos de caso que se sobrepõem às características gerais da investigação qualitativa:

I) À medida que o pesquisador vai adentrando na investigação de um caso, deve estar atento a novos elementos e aspectos importantes, tendo em vista novas buscas e respostas ao longo da investigação, mas sempre fiel aos seus pressupostos teóricos.

II) O estudo tem forte relação com o contexto em que ele se desenvolve: dizemos que o caso está estritamente ligado a situações especificas;

III) Busca retratar a realidade da forma mais completa possível e, assim, envolve a multiplicidade de dimensões presentes em determinada situação. São 
características marcantes a complexidade e a profundidade da investigação, além das interrelações entre os seus componentes;

IV) O pesquisador explora fontes de informações variadas e em momentos diferentes, com variados tipos de informantes.

V) Permite generalizações naturalísticas: os resultados de um estudo de caso podem ser alargados naturalmente a outras situações similares, ou seja, um sujeitoleitor pode associar os dados encontrados com dados que são fruto das suas experiências pessoais;

VI) Procura representar os diferentes pontos de vista presentes numa situação social, assim, diferentes perspectivas da realidade devem emergir da investigação e devem ser retratadas pelo pesquisador.

VII) Busca-se, nessas investigações, uma linguagem expressa a partir de estilos narrativos ilustrados por citações, exemplos e descrições.

Acrescentamos a essas características os apontamentos de Ponte (1994, p.2) que reafirma a particularidade de um estudo de caso e o que se busca ao utilizá-lo:

\begin{abstract}
Um estudo de caso pode ser caracterizado como um estudo de uma entidade bem definida como um programa, uma instituição, um sistema educativo, uma pessoa ou uma unidade social. Visa conhecer em profundidade o seu "como" e os seus "porquês" evidenciando a sua unidade e identidade próprias. É uma investigação que se assume como particularista, isto é, debruça-se deliberadamente sobre uma situação específica que se supõe ser única em muitos aspectos, procurando descobrir o que há nela de mais essencial e característico.
\end{abstract}

Em relação à condução de um estudo de caso que envolve a Teoria da Atividade, Ymagata-Lynch (2010) aponta que a análise de sistemas de atividades é compatível com a pesquisa de estudos de caso porque envolve o exame de sistemas complexos que são difíceis de remover do contexto, além de exigir engajamento do pesquisador para coleta e análise dos dados.

Consideramos que as ideias apresentadas formam um quadro que já permite compreender esta investigação como um estudo de caso qualitativo que envolveu diferentes participantes, sendo que, ao longo da pesquisa, surgiram novos aspectos importantes que foram considerados na investigação.

O pesquisador foi o principal responsável pela coleta de dados, sendo importante destacar a sua presença durante todo o período em que a exposição permaneceu no Brasil. Foram exploradas diversas fontes de dados que serão apresentadas nas próximas seções. Os instrumentos de produção de dados, 
essencialmente descritivos, buscavam captar as diferentes facetas do contexto investigado e a característica da multivocalidade presente no conceito da atividade humana dirigida ao objeto.

Destacamos também a singularidade dessa investigação, ao explorar o processo, não trivial, da vinda de uma exposição científica internacional ao Brasil, que mobilizou diversos setores da sociedade, se mostrando campo frutífero para o estabelecimento de relações entre diferentes sujeitos com diversos ideais e objetivos. Tal contexto se relaciona diretamente com o referencial teórico, objetivos e perguntas de pesquisa que, em suma, buscam, por meio da análise da relação entre atividades humanas, as contradições nelas imbricadas.

Almejando que o leitor se aproprie do cenário desse estudo de caso, apresentamos a seguir, em detalhes, a exposição foco desse estudo.

\subsubsection{A exposição "Túnel da Ciência 3.0" - um caso a ser estudado}

A exposição intitulada "Túnel da Ciência Max Planck 3.0" foi idealizada por cientistas do Instituto Max Planck da Alemanha, fundado no ano de 1948 e que se reconhece como uma das mais importantes sociedades de pesquisa do mundo. A instituição, atualmente, é composta por 5.300 cientistas, entre os quais dezessete já receberam prêmios Nobel. Seu orçamento, em 2012, foi de 1,5 bilhão de euros. ${ }^{18}$

A exposição Túnel da Ciência contou, no Brasil, com um site destinado à sua divulgação em português ${ }^{19}$, onde constava a seguinte afirmação: "a exposição foi concebida com o objetivo de explorar grandes temas da pesquisa básica que é desenvolvida no Instituto, mostrando os desdobramentos do que é pesquisado para a sociedade". Os temas da exposição foram apresentados por meio de textos, imagens, gráficos, vídeos de entrevistas com os pesquisadores, objetos e animações. Com esses recursos, os visitantes puderam ter acesso a discursos de cientistas, além de informações sobre as pesquisas desenvolvidas na instituição.

Como já citado, o Túnel da Ciência, criado em 2000, foi apresentado em 20 países e recebeu mais de nove milhões de pessoas em suas três versões. A

18 Disponível em: https://www.mpg.de/history mpg . Acesso: 20/05/2017

19 Disponível em: http://www.tuneldaciencia.com.br/ . Acesso: 20/05/2017 
versão 3.0, apresentada no Brasil, é a mais recente. Foi lançada na Rússia em 2013 e está distribuída em oito módulos temáticos: Universo - dos quarks ao cosmo; Matéria - design do mundo microscópico; Vida - dos elementos aos sistemas; Complexidade - dos dados à compreensão; Cérebro - fábrica de maravilhas na cabeça; Saúde - pesquisa para a medicina do futuro; Energia - vida no Antropoceno; e Sociedade - o mundo em mobilidade.

Abaixo, apresentamos um croqui da exposição (Figura 8), evidenciando a distribuição dos módulos expositivos e os aparatos interativos presentes. Cada módulo representou uma temática e, na proposta original, estaria diretamente ligado a outro,de acordo com a sequência apresentada acima (Universo à Sociedade). Entretanto, devido ao espaço selecionado para a edição brasileira, essa disposição não foi implementada.

Apesar da linearidade inerente a um túnel, os módulos são independentes e, dessa forma, o visitante brasileiro poderia começar por qualquer deles ou visitar o de maior interesse. Na maioria dos casos, a visita se iniciava pelo módulo Universo, por ser o mais próximo da entrada ${ }^{20}$.

${ }^{20}$ Dados obtidos a partir de um levantamento realizado em parceria com o MCTIC e o Museu de Astronomia e Ciências Afins (MAST), não publicado. 


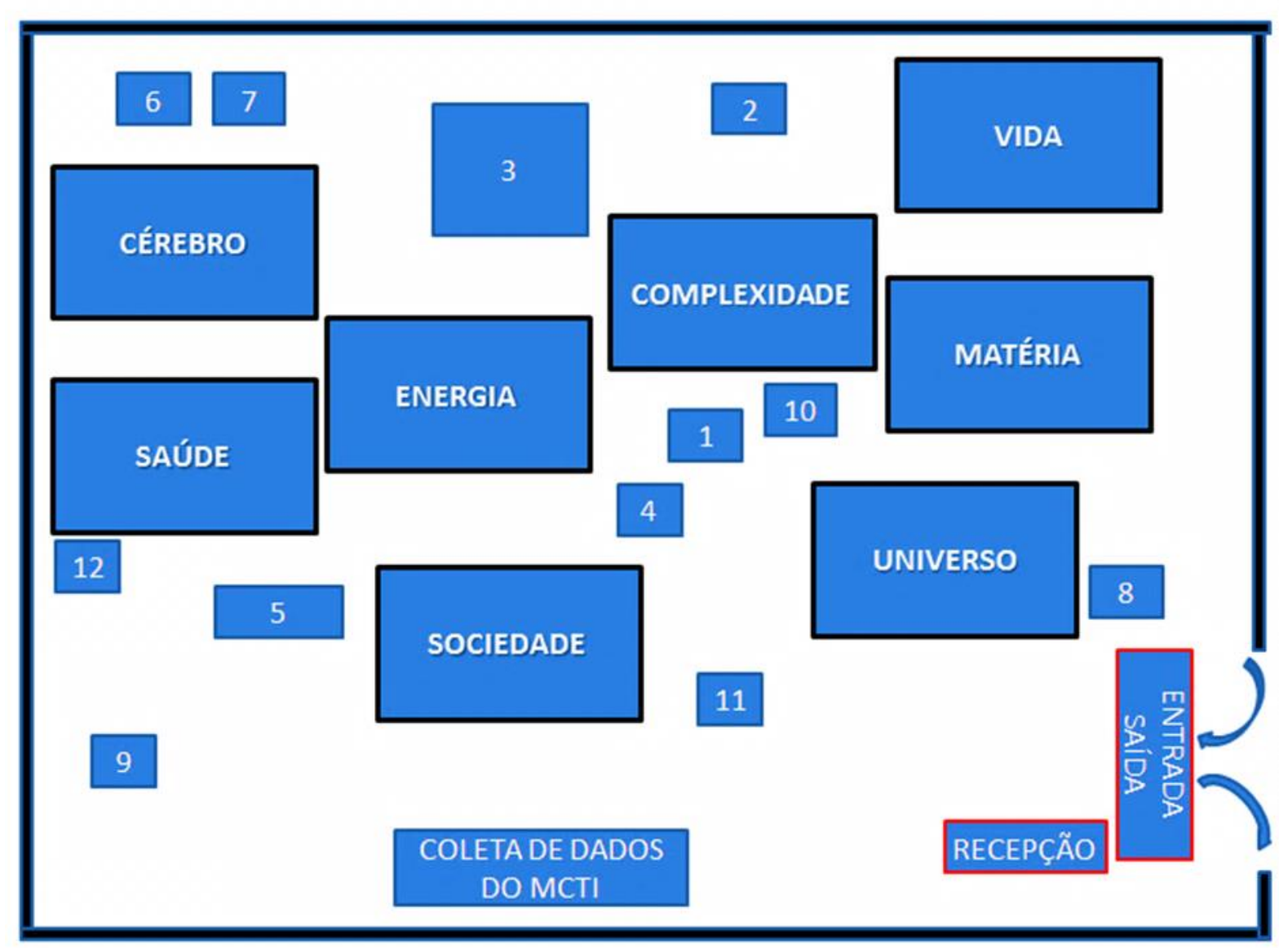

Figura 8 - Croqui do Espaço expositivo do "Túnel da Ciência 3.0 Max Planck" no Brasil. ${ }^{21}$ Fonte: autoria própria.

O padrão expositivo predominante consistia, para cada módulo, em painéis com textos e imagens sobre as pesquisas desenvolvidas no Max Planck, um totem com objetos relacionados à temática trabalhada e um QR Code (que permitia aos monitores, com o auxílio de um iPod®, explorar digitalmente o conteúdo envolvido no módulo). Além disso, cada módulo possuía um painel touchscreen, através do qual o visitante poderia explorar os diversos vídeos com cientistas do Max Planck envolvidos com o tema. Nas imagens abaixo, exemplificamos alguns elementos expositivos.

${ }^{21}$ Os números referem-se aos aparatos presentes na exposição e descritos no quadro 3. Aparatos da exposição "Túnel da Ciência 3.0 Max Planck" no Brasil. 


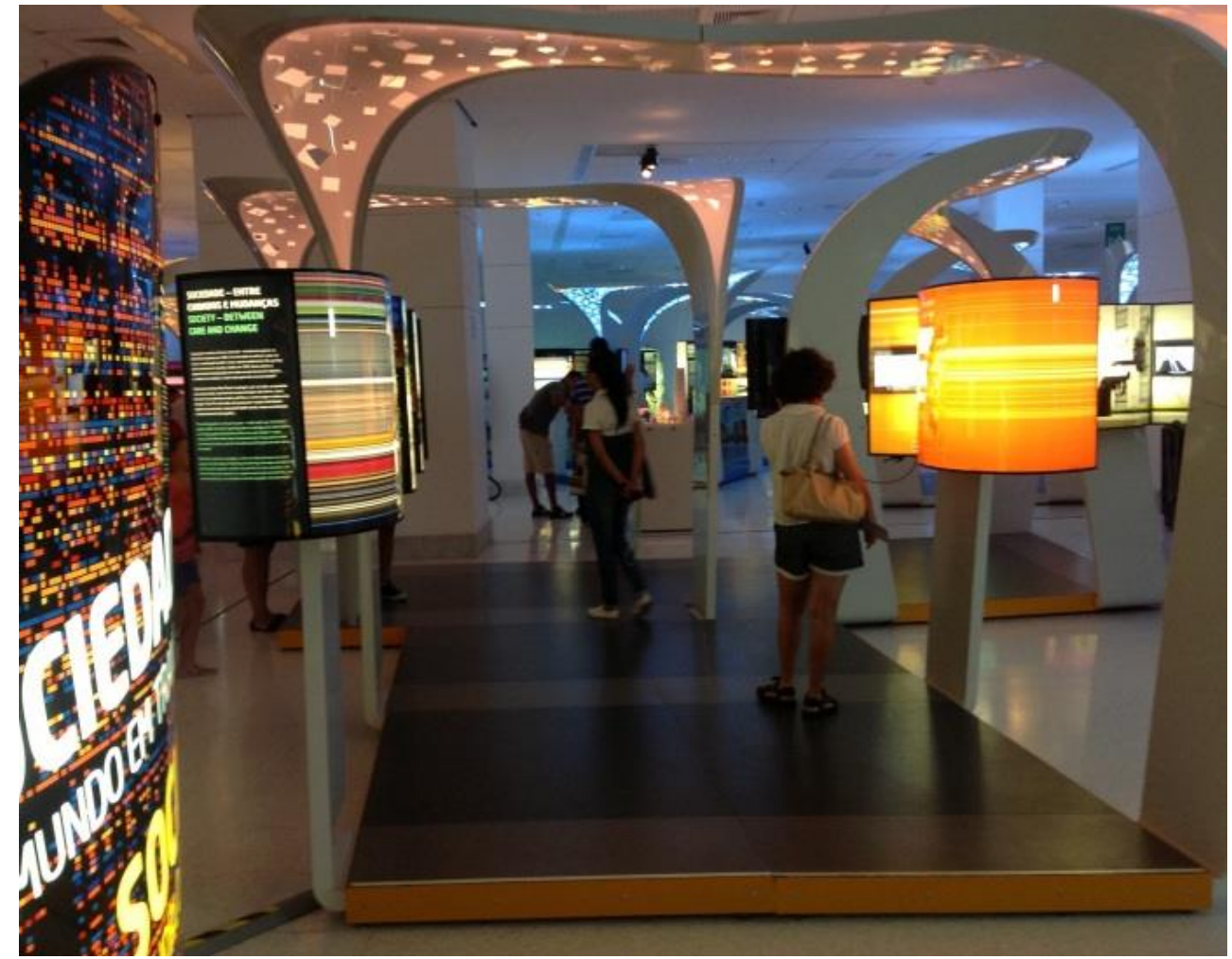

Figura 9 - Visão geral de um módulo expositivo. Fonte: Autoria própria.

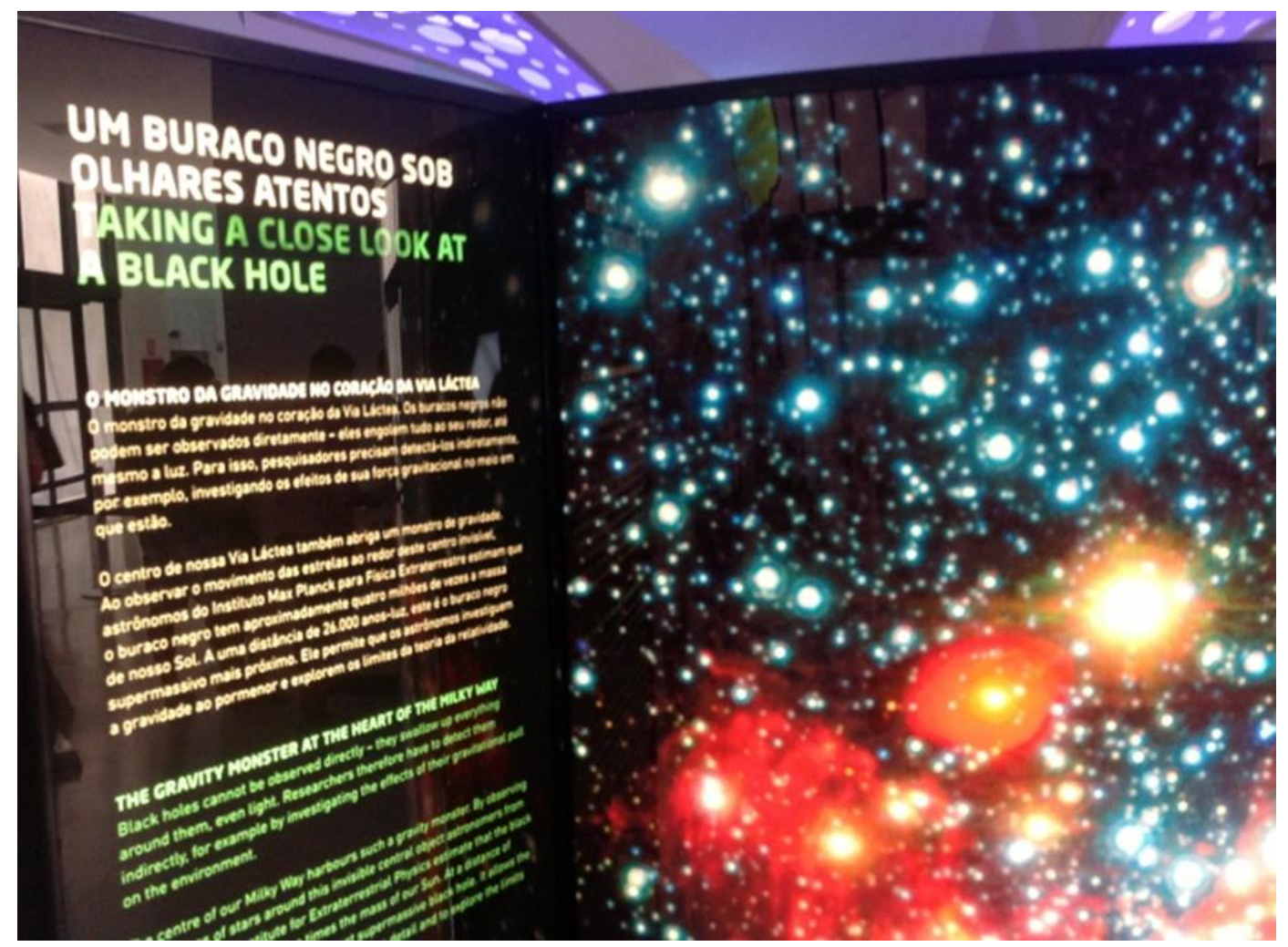

Figura 10 - Painel com textos e imagens. Fonte: autoria própria. 


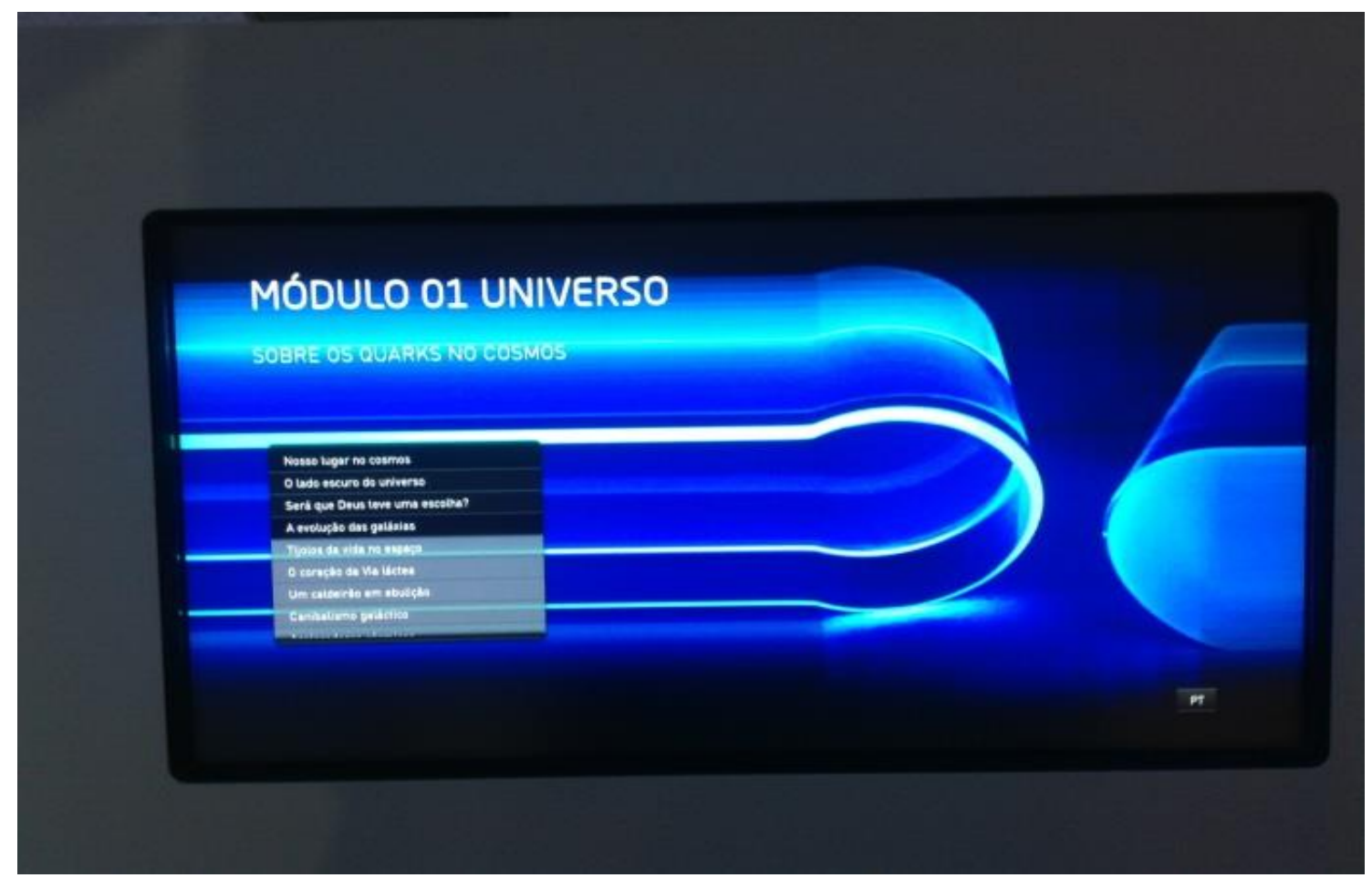

Figura 11 - Painel touchscreen com vídeos. Fonte: autoria própria.

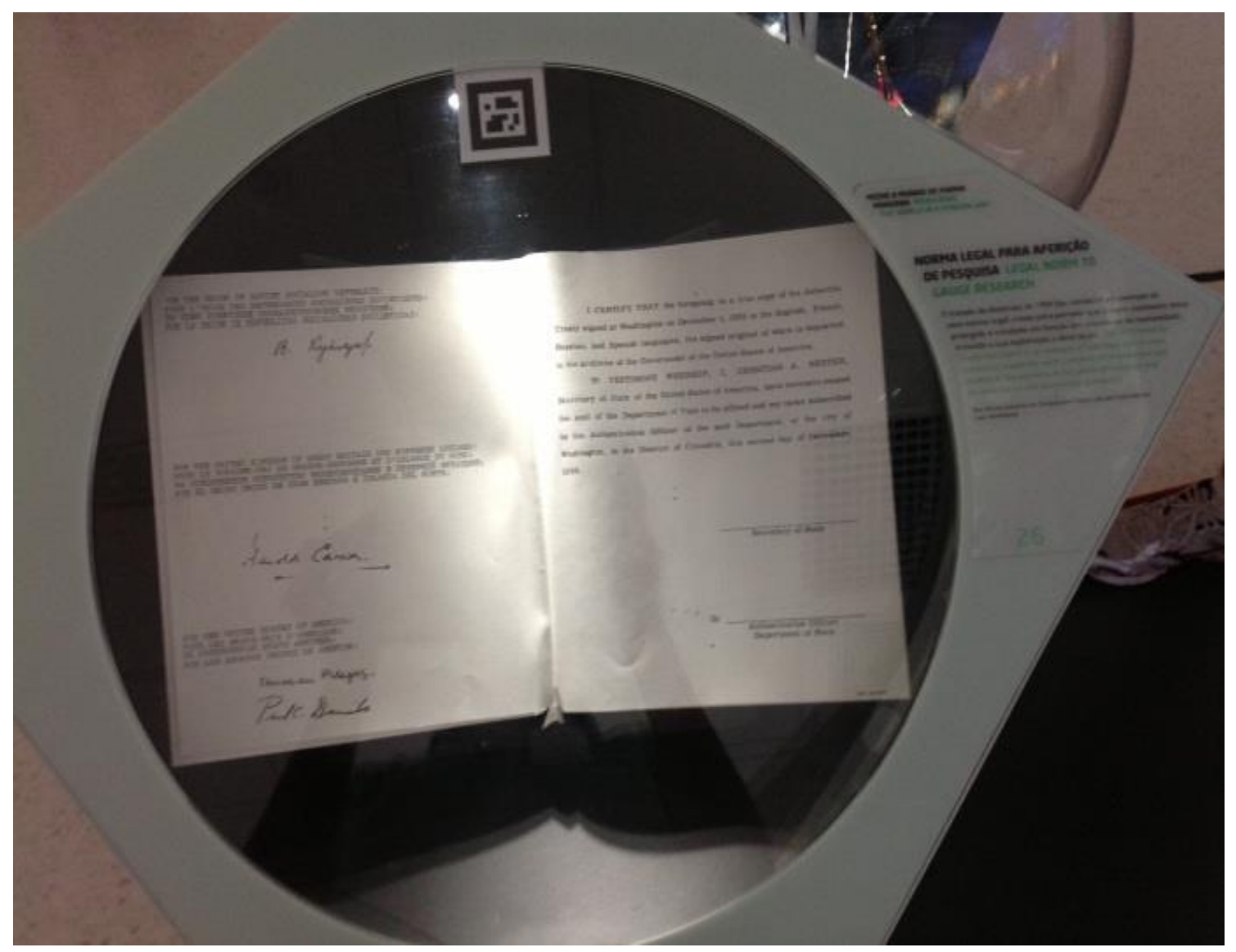

Figura 12 - Totem com objetos e QR Code (Quick Response Code). Fonte: autoria própria. 
Além desse padrão expositivo, em vários módulos foram utilizados aparatos que permitiam a interação com o visitante e outros objetos relacionados ao tema. No croqui da exposição (Figura 8), esses estão numerados de 1 a 12 . Abaixo, apresentamos um quadro com esses objetos e uma breve descrição (QUADRO 2).

QUADRO 2. Aparatos da exposição "Túnel da Ciência 3.0 Max Planck" no Brasil.

\begin{tabular}{|c|c|c|}
\hline № & Aparato e módulo & Descrição \\
\hline 1 & $\begin{array}{l}\text { Cidade de Lego® } \\
\text { (Sociedade) }\end{array}$ & $\begin{array}{l}\text { Esquema de uma cidade } \\
\text { construída. }\end{array}$ \\
\hline 2 & $\begin{array}{l}\text { Globo Mudanças } \\
\text { Climáticas } \\
\text { (Complexidade) }\end{array}$ & $\begin{array}{l}\text { Globo dinâmico que mostra as } \\
\text { mudanças da temperatura ao } \\
\text { longo do ano no mundo. }\end{array}$ \\
\hline 3 & $\begin{array}{l}\text { Cinema } \quad \text { (Sem } \\
\text { módulo) }\end{array}$ & $\begin{array}{l}\text { Apresenta vídeos institucionais } \\
\text { do Max Planck. }\end{array}$ \\
\hline 4 & $\begin{array}{l}\text { Painel Cidade da } \\
\text { Energia (Energia) }\end{array}$ & $\begin{array}{l}\text { Painel touchscreen que } \\
\text { mostra uma cidade } \\
\text { pautada na energia } \\
\text { sustentável. }\end{array}$ \\
\hline 5 & $\begin{array}{l}\text { Espelho mágico } \\
\text { (Saúde) }\end{array}$ & $\begin{array}{l}\text { Simulador baseado em realidade } \\
\text { aumentada que funciona como } \\
\text { um raio-x. }\end{array}$ \\
\hline 6 & $\begin{array}{l}\text { Máquina do } \\
\text { Cérebro (Cérebro) }\end{array}$ & $\begin{array}{l}\text { Simulador de ressonância } \\
\text { magnética funcional. }\end{array}$ \\
\hline 7 & $\begin{array}{l}\text { Máquina } \\
\text { reconhecimento } \\
\text { fácil (Cérebro) }\end{array}$ & $\begin{array}{l}\text { Máquina que reconhece } \\
\text { expressões faciais } \mathrm{e} \\
\text { identifica o sexo do } \\
\text { visitante. }\end{array}$ \\
\hline
\end{tabular}




\begin{tabular}{|l|l|l|}
\hline $\mathbf{8}$ & $\begin{array}{l}\text { Robô enviado a } \\
\text { Marte (Universo) }\end{array}$ & $\begin{array}{l}\text { Réplica do veículo de } \\
\text { exploração espacial } \\
\text { Rover. }\end{array}$ \\
\hline $\mathbf{9}$ & $\begin{array}{l}\text { Ilusão de óptica } \\
\text { (Sem módulo) }\end{array}$ & $\begin{array}{l}\text { Face humana que cria } \\
\text { uma ilusão de óptica entre } \\
\text { o côncavo e o convexo. }\end{array}$ \\
\hline 10 & $\begin{array}{l}\text { Esponja de vidro } \\
\text { (Matéria) } \\
\text { Totem Institucional } \\
\text { (Sem módulo) }\end{array}$ & $\begin{array}{l}\text { Esqueleto de sílica de } \\
\text { uma esponja. }\end{array}$ \\
\hline 12 & $\begin{array}{l}\text { Totem touchscreen com } \\
\text { vídeos institucionais do } \\
\text { Instituto Max Planck. } \\
\text { temperatura } \\
\text { (Saúde) }\end{array}$ & $\begin{array}{l}\text { Máquina que reconhece a } \\
\text { temperatura de objetos e } \\
\text { de pessoas com o auxílio } \\
\text { de uma câmera. }\end{array}$ \\
\hline
\end{tabular}

No âmbito brasileiro, a exposição concebida pelo Instituto Max Planck foi viabilizada pela produtora de eventos educacionais Geração (nome fictício), com patrocínio e parcerias com empresas privadas e de setores públicos do Brasil e da Alemanha. Nesse sentido, destacamos a participação do antigo Ministério da Ciência Tecnologia e Inovação (MCTI) ${ }^{22}$, que teve o papel de apoiar a produtora Geração nas negociações com o governo alemão para a vinda da exposição, bem como da Universidade Federal de São Paulo (UNIFESP), responsável por selecionar o quadro de monitores.

22 Em 2014, ano da vinda da exposição, o Ministério da Ciência Tecnologia e Inovação (MCTI), através da Secretaria de Ciência e Tecnologia para Inclusão Social, auxiliou na vinda do Túnel da Ciência. Em 2016 com a reestruturação dos Ministérios, o MCTI foi fundido ao Ministério das Comunicações, passando a se chamar Ministério da Ciência Tecnologia, Inovação e Comunicações (MCTIC). Desse modo, utilizaremos essa denominação ao longo da Tese. 
O objetivo geral do Túnel da Ciência no Brasil, como apresentado no site ${ }^{23}$ da exposição, é contribuir para a popularização e a divulgação da ciência, promovendo o acesso e a apropriação do conhecimento científico produzido pelo Instituto Max Planck, visando enriquecer o repertório científico de estudantes e do público em geral, além de gerar oportunidades de inclusão social das parcelas mais vulneráveis da população brasileira e de redução das desigualdades sociais por meio da democratização do saber.

Sob o slogan de "maior e mais interativa exposição de educação para as ciências do mundo"2 o Túnel da Ciência foi apresentado no Brasil no período de 30 de janeiro a 21 de fevereiro de 2014, em São Paulo (SP), ocupando uma área de mil metros quadrados em um shopping da região central da cidade. O ingresso era gratuito e houve um grande esforço para a criação de público, além de uma parceria com a Secretaria Municipal de Educação de São Paulo, para a visitação de escolares do ensino fundamental II.

O público final da exposição foi de 39.452 visitantes $^{24}$, o que representa um número semelhante às grandes exposições científicas e itinerantes citadas anteriormente, levando em consideração o tempo de permanência no país.

Como podemos perceber, diversos sujeitos e esferas da sociedade estiveram envolvidos nesse processo, sendo um grande desafio agregar os diversos pontos de vista desses sujeitos na presente pesquisa.

\subsection{PARTICIPANTES DA PESQUISA}

Sabendo da grande quantidade de sujeitos envolvidos com o Túnel da Ciência, buscamos agregar, para a produção de dados, as diversas partes envolvidas nesse processo. Os sujeitos foram considerados individualmente, mas, por vezes, suas falas tomadas como representativas de uma instituição ou grupo.

Os sujeitos convidados foram esclarecidos sobre os objetivos da investigação e sobre seus direitos de desistir a qualquer momento. Foi assinado um termo de consentimento livre esclarecido, autorizando o uso, de forma anônima, das falas e de imagens (APÊNDICE A - Termo de consentimento livre e esclarecido

${ }^{23}$ Túnel da Ciência. Disponível em: http://www.tuneldaciencia.com.br Acesso em:20 jun de 2016.

${ }^{24}$ Informação obtida informalmente em conversa com funcionários da produtora. 
(maiores de 18 anos) e APÊNDICE B - Termo de consentimento livre e esclarecido (menores de 18 anos)).

Em alguns casos, os participantes foram escolhidos por sua posição de representatividade dentro do grupo ao qual pertencem e, em outros, de modo aleatório ou por questão de disponibilidade. Esclareceremos essas escolhas metodológicas na descrição de cada categoria de sujeitos, sendo eles identificados a partir de nomes fictícios.

Rafael (Representante do Instituto Max Planck) - O Instituto Max Planck foi responsável pela concepção e elaboração da exposição. Como forma de representar a instituição, um de seus cientistas, responsável pelo Túnel da Ciência no Brasil, foi convidado a participar da pesquisa (APÊNDICE D - Roteiro de Entrevista semiestruturada - Representante do Instituto Max Planck). Rafael é alemão, filósofo e possui mestrado e doutorado em Filosofia. Foi professor universitário, atuou em museus e, atualmente, está vinculado ao Instituto Max Planck, com função diretamente ligada ao Túnel da Ciência. Ele esteve envolvido na formação inicial dos monitores que atuaram na exposição.

Tiago (Representante do antigo Departamento de Difusão e Popularização da Ciência e Tecnologia do Ministério da Ciência, Tecnologia, Inovação e Comunicação (MCTIC) - (APÊNDICE E - Roteiro de entrevista semiestruturada - Representante do Departamento de Popularização e Difusão da Ciência e Tecnologia do Ministério da Ciência, Tecnologia e Inovação) - A instituição foi escolhida como participante da pesquisa por ser uma promotora de políticas públicas de popularização da Ciência e Tecnologia, sendo responsável pela primeira tentativa de trazer o Túnel da Ciência ao Brasil, além de ter exercido um importante papel político e financeiro na concretização do processo em 2014.

O objetivo do departamento é promover a articulação entre diversos níveis de governo e também com entidades representativas dos diversos setores sociais, com o objetivo de difundir os conhecimentos científicos e tecnológicos. Além disso, presta-se a formular e implementar uma política pública de popularização da C\&T.

O participante escolhido esteve diretamente envolvido nesse processo de vinda da exposição ao Brasil. Por essa inserção e por ter atuado como coordenador de um museu de ciências e como tecnologista sênior do MCTIC, foi escolhido como 
sujeito participante.

Marcelo (Representante da Produtora Geração) - A produtora Geração (nome fictício) é uma empresa privada que atua na área de projetos educacionais e culturais há trinta anos. Foi a representante exclusiva do Túnel da Ciência no Brasil, sendo responsável pela organização, logística, marketing e, em certa medida, pela formação e acompanhamento dos monitores.

Escolhemos como representante da produtora Geração, Marcelo, pois fez parte do processo de vinda da exposição, desde o início das negociações.

Marcelo tem 52 anos, é do sexo masculino, possui graduação em economia e especialização em gestão para sustentabilidade. Durante a juventude, atuou como voluntário em acampamentos e colônias de férias e, com 18 anos, ao ingressar na faculdade, fundou a Produtora Geração para prestar serviços de recreação que possuíssem algum aspecto de formação de "valores ou conceitos", inicialmente, de uma "forma intuitiva".

Ao longo da década de 1980, a empresa incorporou em suas atividades, gradativamente, aspectos relacionados a questões ambientais. Além disso, iniciouse uma preocupação com sua consistência pedagógica e científica. Ao longo dos anos, a instituição já produziu e executou diversos projetos na área educacional, como oficinas, exposições, entre outros.

Hoje, Marcelo atua nas áreas comercial e de estratégia, em busca de patrocinadores e apoiadores.

Monitores - Participaram da pesquisa cinco monitores que atuaram durante a exposição. São alunos de graduação ou pós-graduação da Universidade Federal de São Paulo e receberam uma bolsa para realizar o trabalho educativo junto ao público da exposição. A escolha dos participantes foi realizada de modo aleatório entre aqueles que se disponibilizaram a participar. Os entrevistados foram identificados como: Breno, Isabela, Daiane, Cibele e Vilma.

Breno - No momento da entrevista, cursava graduação em Letras pela UNIFESP. Tinha 21 anos, é do sexo masculino e não havia atuado anteriormente como monitor. As principais motivações para participar da ação educativa na exposição foram: o certificado de atuação que contribuiria para o seu currículo, a experiência de monitoria que, para ele, está relacionada com o desenvolvimento de 
habilidades de falar em público, e o valor da bolsa oferecida.

Isabela - No ano da pesquisa, tinha 27 anos, é do sexo feminino, possui graduação em Biomedicina, mestrado em Psiquiatria e cursava o doutorado pelo mesmo programa. Relatou nunca ter atuado como monitora em exposições científicas ou espaços semelhantes, porém destacou ter participado como professora em cursinhos pré-vestibular. As motivações iniciais para realizar o trabalho estavam relacionadas ao fato da exposição ser ligada ao Instituto Max Planck, o que representava, para ela, uma possibilidade de contatos profissionais. Porém relata que, durante a sua atuação, viu também a possibilidade de exercer práticas docentes, que, em sua visão, são essenciais para a carreira de pesquisadora.

Daiane - Tinha 24 anos, é do sexo feminino, possui graduação em Nutrição e cursava mestrado em Ciência e Tecnologia dos Alimentos pela UNIFESP. Relatou nunca ter atuado como monitora. $O$ interesse em realizar o trabalho educativo na exposição estava ligado às questões do certificado de atuação, que fortaleceria seu currículo, e à possibilidade de fazer contatos profissionais.

Cibele - Graduanda em Engenharia química, 22 anos, sexo feminino. Segundo o afirmado na entrevista, essa era a sua primeira experiência como monitora de uma exposição. Relatou que não houve muitas informações sobre como seria o trabalho, mas que se interessou pela oportunidade porque acreditava que era algo novo e não muito frequente no nosso país.

Vilma - Graduanda em Letras, 20 anos, sexo feminino. Para Vilma, a exposição era uma oportunidade de aprimorar os seus conhecimentos na sua área de formação que está ligada à educação. Relata que queria ter contato com os alunos das escolas visitantes para aprimorar suas habilidades relativas à docência, que ela acreditava ter muita relação com a monitoria em exposições, apesar de nunca ter tido experiências nessa área.

Público espontâneo - Essa categoria compreende visitantes que não realizaram agendamento prévio. Para participação na pesquisa, selecionamos três grupos familiares com até duas crianças. Esclarecemos que a concepção de família aqui considerada foi de um grupo de pessoas composto por adulto(s) acompanhado(s) de criança(s) ou adolescente(s), com convivência frequente e que possuíssem algum vínculo de parentesco, não necessariamente de consanguinidade. Além disso, o número de integrantes está relacionado à melhor 
captação do áudio conforme pesquisas desenvolvidas pelo nosso grupo de pesquisa (BIZERRA, 2009; RUFATO, 2015).

O motivo da escolha de grupos familiares como representativos do público espontâneo decorre do fato de que, em geral, observamos maior frequência dessa configuração entre os grupos visitantes. Além disso, são os públicos mais investigados no que tange os visitantes não escolares, o que permite maiores aproximações com a literatura. Estamos cientes, entretanto, que esse recorte confere especificidades ao público espontâneo investigado. Foram abordados todos os grupos que atendiam aos critérios acima até se atingir três grupos que aceitaram participar da visita, identificados como Família 1, Família 2 e Família 3. Dos grupos abordados que atendiam aos critérios, 8 se recusaram a participar da pesquisa.

Família 1 - A Família 1 é composta por Roberta que é do sexo feminino, tem 37 anos e possui mestrado em biomedicina. O outro membro da família é o filho Gabriel que é do sexo masculino e tem 8 anos.

O grupo familiar reside na cidade de São Paulo e no último ano visitou três museus, sendo dois deles aquários. Entre os espaços visitados estão os aquários de São Paulo e de Santos, ambos no estado de São Paulo. Além disso, possuem o hábito de ir ao Espaço Catavento Cultural, localizado na região central da capital paulista. Roberta relatou que já visitaram por cinco vezes esse espaço. Para ela, ir a museus, incluindo aquários e zoológicos, é importante, pois oferecem um conteúdo diferenciado e que não é apresentado na mídia.

Em relação aos hábitos familiares relacionados à ciência, Roberta declarou que sempre assistem programas de televisão e leem livros com temáticas científicas. Quando questionada sobre idas a palestras e eventos, Roberta relatou que isso é um hábito comum para ela devido à sua profissão, bem como a realização de experimentos científicos.

A família tomou conhecimento sobre a exposição pelo pai, funcionário de uma das empresas patrocinadoras. Entre as expectativas da família, foram apontados alguns objetos presentes na exposição: o "espelho mágico" e a réplica do robô enviado ao planeta Marte. Roberta relatou que a grande motivação para a visita era conhecer assuntos não apresentados em outros meios de comunicação.

Família 2 - A Família 2 é composta por Tina, 45 anos, sexo feminino, com graduação em Direito, e sua filha Antônia, do sexo feminino e com 6 anos.

O grupo familiar reside na cidade de São Paulo e no último ano visitaram o 
Museu Afro e o Museu de Arte Moderna. Tina relatou que gostam mais do primeiro espaço pelo fato de ser negra e de ter trabalhado lá. Além disso, aponta que frequenta esses locais pela possibilidade de conhecer outras culturas e a arte de outros países.

Em relação aos hábitos familiares relacionados às Ciências, Tina declarou que sempre assistem programas de televisão relacionados a esse tema. Sobre leitura de livros e revistas científicas, Tina declarou que sempre realiza essa atividade, porém a filha não tem o costume. A Família 2 não tem o hábito de frequentar palestras e eventos científicos.

Tina declarou que souberam da exposição por meio de uma revista de grande circulação nacional e da televisão. As chamadas, segundo ela, foram sucintas, mas convidavam as pessoas a visitarem uma feira científica internacional. A motivação da família para a realização da visita era conhecer assuntos novos e Tina aponta que esperavam ser surpreendidas.

Família 3 - A Família 3 é composta pela mãe Isabel, 41 anos, formada em Engenharia química, e pelas filhas Rafaela (13 anos) e Juliana (11 anos).

A família reside na cidade de São Paulo e relata ter visitado muitos museus no último ano, sendo um hábito comum para eles. Quando questionadas sobre quais preferem, a mãe afirmou que gostam de lugares que tenham objetos interativos, sendo que o Espaço Catavento Cultural foi utilizado como exemplo por Isabel. Relataram ainda que frequentam esses lugares por gostarem de ciência e também pela necessidade de conhecerem coisas novas, citando a atualização dos conhecimentos como um fator importante.

Em relação aos hábitos familiares relacionados às Ciências, a Família 3 assiste, às vezes, programas de televisão relacionados ao tema e sempre leem livros e revistas com temáticas científicas. Costumam ir a palestras, eventos ou instituições científicas sempre que há oportunidade. Entendem que realizar essas atividades em família é importante para seu entretenimento e conhecimento.

A Família 3 soube da exposição por meio de sites na internet e buscou mais informações na página oficial. Na notícia, era relatado apenas que o Túnel da Ciência era uma exposição científica, sendo que a temática atraiu a atenção da família. Entre os motivos para a realização da visita, Isabel declarou como principais fatores: tempo disponível, gratuidade e localização (local fechado/shopping). Declarou ainda que não tinham muitas expectativas, apenas curiosidade. 
Para facilitar a leitura da análise dos dados e o entendimento da pesquisa, apresento abaixo um quadro com uma síntese e identificação dos participantes da pesquisa (QUADRO 3).

QUADRO 3. Identificação e nomes fictícios dos participantes da pesquisa

\begin{tabular}{|c|c|}
\hline Identificação & Nome fictício \\
\hline Representante do Instituto Max Planck & Rafael \\
\hline $\begin{array}{l}\text { Representante do antigo Departamento } \\
\text { de Difusão e Popularização da Ciência e } \\
\text { Tecnologia do Ministério da Ciência, } \\
\text { Tecnologia, Inovação e Comunicação } \\
\text { (MCTIC) }\end{array}$ & Tiago \\
\hline Representante da Produtora Geração & Marcelo \\
\hline Família 1 & Roberta (mãe) e Gabriel (filho) \\
\hline Família 2 & Tina (mãe) e Antônia (filha) \\
\hline Família 3 & $\begin{array}{l}\text { Isabel (mãe), Rafaela (filha) e Juliana } \\
\text { (filha) }\end{array}$ \\
\hline Monitores & $\begin{array}{l}\text { Breno, Isabela, Daiane, Cibele e } \\
\text { Vilma. }\end{array}$ \\
\hline
\end{tabular}

\subsubsection{Envolvimento dos sujeitos com o Túnel da Ciência}

Como apresentamos anteriormente, no processo de viabilização do "Túnel da Ciência 3.0" no Brasil, há diferentes grupos de indivíduos envolvidos. A partir dos objetivos da nossa pesquisa, entendemos que seja relevante olhar para esses grupos e entender como eles se relacionam por meio de suas atividades.

Para sintetizar as etapas que ocorreram nesse percurso de negociação até a concretização do objeto, com a exibição da exposição no nosso país, elaboramos um diagrama (Figura 8) que apresenta, cronologicamente, episódios importantes e 
os sujeitos envolvidos.

Percebemos, assim, que durante o processo de negociação entre o governo brasileiro e o governo alemão (Etapa 1), ocorrido anteriormente à exibição, estavam envolvidos, em maior ou menor grau, os representantes do Instituto Max Planck, do MCTIC e da Produtora Geração. Esse processo começou em fevereiro de 2012 e, devido a alguns entraves políticos e financeiros, prolongou-se até o ano de 2014.

Os três representantes citados anteriormente também se fazem presentes no momento oficial de formação dos monitores (Etapa 2), em que foi estabelecido o que se esperava desses sujeitos, quais funções deveriam realizar e quais as melhores maneiras de se realizar a interação com o público. O momento de formação contou ainda com a apresentação da exposição pelo representante do Max Planck, que detalhou alguns dos conteúdos conceituais envolvidos. É importante salientar que, além disso, foi distribuída uma apostila elaborada pelo próprio Instituto sobre os módulos expositivos.

A abertura oficial (Etapa 3) aconteceu no dia 29 de janeiro de 2014, com a presença de autoridades representantes do Max Planck, MCTIC, Produtora Geração e público espontâneo. Nessa mesma data, o pesquisador começa a sua atuação na coleta de dados, que perdurou até o fim da exposição no país. Após a inauguração, os únicos participantes da pesquisa que permaneceram trabalhando presencialmente na exposição foram o representante da Produtora Geração e os monitores.

Próximo do final da exposição (Etapa 5), o representante do MCTIC retorna à exposição para auxiliar e verificar o andamento do processo. Desde a inauguração da exposição, iniciou-se um período de avaliação (Etapa 6) com participação dos representantes do MCTIC, Produtora Geração e Max Planck. Porém, é importante salientar que essas avaliações foram realizadas de modos independentes. 


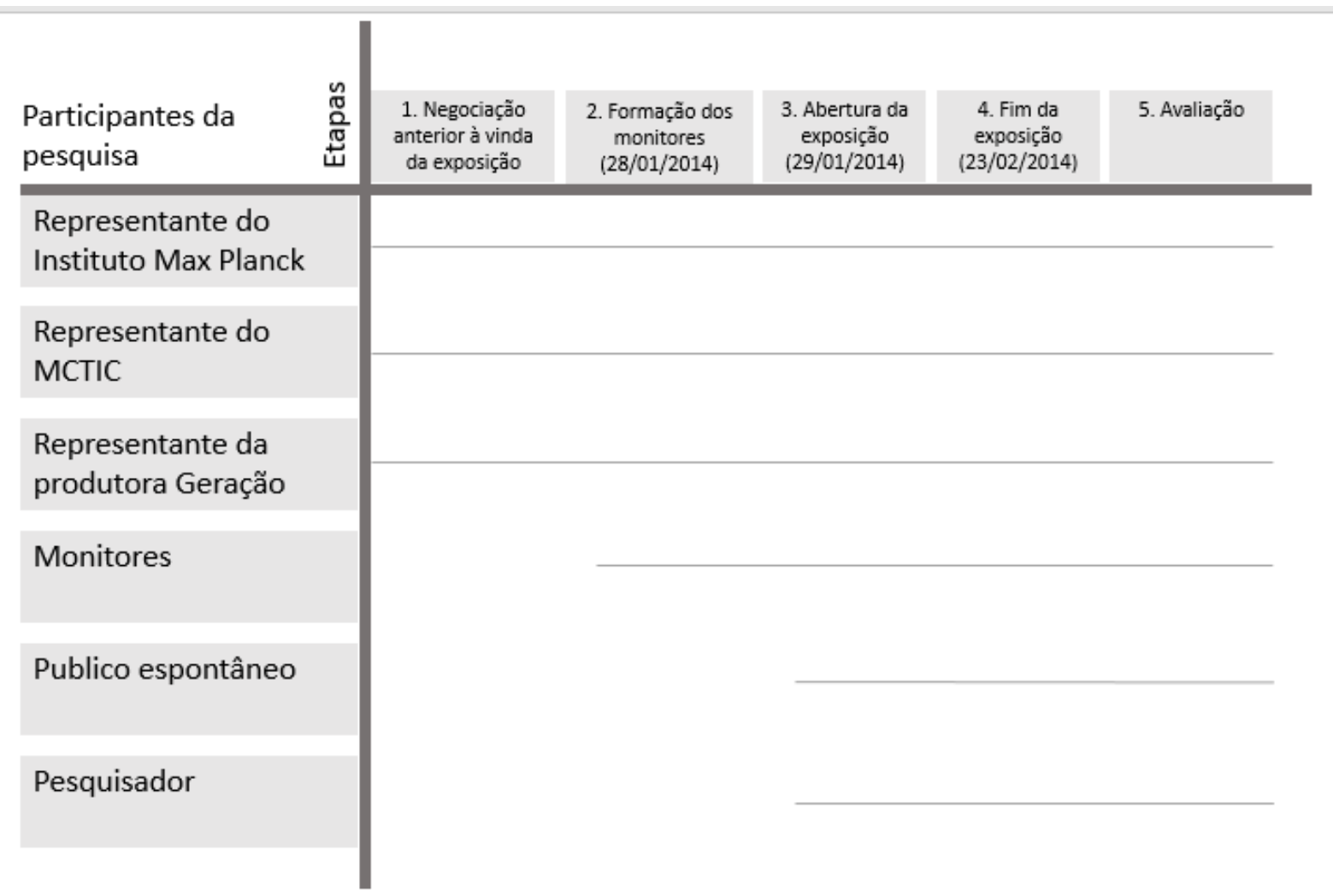

Figura 13 - Diagrama do envolvimento dos sujeitos com a vinda e realização do Túnel da Ciência 3.0 no Brasil. Fonte: Autoria própria.

A figura 13 visa situar o leitor em relação ao grupo de participantes que constituem os sujeitos da presente pesquisa.

\subsection{PRODUÇÃO DE DADOS}

A seguir, descrevemos como compomos nossos dados, as ferramentas utilizadas, o motivo de as termos escolhido e como a coleta foi realizada. Foram utilizadas diferentes técnicas, sendo elas: a) entrevistas semiestruturadas; b) gravação de áudio e vídeo da visita; c) notas de campo.

a) Entrevistas: A primeira parte da produção de dados compreendeu entrevistas com todos os participantes da pesquisa. As entrevistas foram realizadas a partir de um roteiro flexível (semiestruturado), com uma série de questões encadeadas, que podiam levar a outras e exigir aprofundamento. Foram gravadas em áudio e transcritas na íntegra. Essa etapa foi fundamental para entender os diferentes pontos de vista dos participantes, como aponta Duarte (2004):

Entrevistas são fundamentais quando se precisa/deseja mapear 
práticas, crenças, valores e sistemas classificatórios de universos sociais específicos, mais ou menos bem delimitados, em que os conflitos e contradições não estejam claramente explicitados. Nesse caso, se forem bem realizadas, elas permitirão ao pesquisador fazer uma espécie de mergulho em profundidade, coletando indícios dos modos como cada um daqueles sujeitos percebe e significa sua realidade e levantando informações consistentes que lhe permitam descrever e compreender a lógica que preside as relações que se estabelecem no interior daquele grupo, o que, em geral, é mais difícil obter com outros instrumentos de coleta de dados (DUARTE, 2004, P. 215).

Segundo Rodrigues (2013, p. 69), "para compreender os modos de manifestação e o papel das contradições, faz-se necessário incluir as vozes dos sujeitos, suas impressões e suas próprias versões da história." Assim, tomar depoimentos como fonte de investigação implica extrair daquilo que é subjetivo e pessoal o que nos permite pensar a dimensão coletiva, isto é, o que nos permite compreender a lógica das relações que se estabelecem (estabeleceram) no interior dos grupos sociais dos quais o entrevistado participa (participou), em um determinado tempo e lugar (DUARTE, 2004, p. 219).

Com esses objetivos, os roteiros de entrevistas foram elaborados de modo que se pudesse compreender possíveis relações estabelecidas entre os participantes da pesquisa e o processo de vinda da exposição. As entrevistas foram gravadas e transcritas, sendo os dados organizados para a análise.

A entrevista com o representante do Instituto Max Planck, Rafael, foi realizada na abertura da exposição no Brasil, em língua inglesa e traduzida, posteriormente, para língua portuguesa. Foram abordados três eixos principais: formação profissional e atuação, concepção de divulgação científica e ciência e tópicos relacionados aos objetivos e expectativas da exposição no Brasil e no mundo (APÊNDICE D - Roteiro de Entrevista semiestruturada - Representante do Instituto Max Planck).

A entrevista com Tiago, representante do Departamento de Popularização e Difusão da Ciência e Tecnologia do MCTIC, aconteceu um ano e meio após o fim da exposição. Foram abordados três eixos principais: formação profissional, histórico de atuação e concepções sobre divulgação científica do MCTIC e a relação entre o Túnel da Ciência 3.0 no Brasil e o MCTIC (APÊNDICE E - Roteiro de entrevista semiestruturada - Representante do Departamento de Popularização e Difusão da Ciência e Tecnologia do Ministério da Ciência, Tecnologia, Inovação e Comunicação). 
O representante da produtora Geração, Marcelo, foi entrevistado no último dia da exposição, optando-se por abordar três temáticas: formação profissional e atuação, histórico da empresa e contato com o Instituto Max Planck e a produção do Túnel da Ciência 3.0 no Brasil (APÊNDICE F - Roteiro de entrevista semiestruturada - Diretor da Produtora Geração).

As entrevistas com os cinco monitores (Breno, Isabela, Daiane, Cibele e Vilma) ocorreram em datas diferentes. Por meio delas, foi possível investigar sobre sua formação profissional, a atuação na exposição e as opiniões sobre o Túnel da Ciência (APÊNDICE G - Roteiro de entrevista semiestruturada com os monitores).

O público espontâneo foi entrevistado antes e após à visita e o objetivo foi gerar subsídios para compreender: a formação dos sujeitos, sua relação com museus e exposições científicas e as impressões sobre o Túnel da Ciência. Esse último tópico foi abordado nas duas etapas da entrevista. (Apêndice $\mathrm{H}$ - Roteiro de entrevista semiestruturada Público espontâneo - Pré visita e Apêndice I - Roteiro de entrevista semiestruturada Público espontâneo - Pós visita).

b) Filmagem das visitas: $O$ uso da gravação em áudio e vídeo teve como objetivo registrar as visitas das três famílias representantes do público. A partir desse material, é possível compreender as relações que se estabelecem no processo de ressignificação da exposição envolvendo o público e os monitores.

Para isso, foi realizada a gravação em áudio e vídeo utilizando o Zoom Q2HD®, aparelho carregado pelo visitante, que possibilitou registrar as falas estabelecidas, além dos objetos observados, o circuito percorrido e o tempo de permanência nos módulos. Foi utilizada, ainda, uma câmera filmadora, a certa distância, a fim de identificar as ações desenvolvidas durante o circuito e auxiliar posteriormente na análise dos dados a partir do cruzamento com os registros do Zoom Q2HD®. Essa técnica de coleta de dados já foi utilizada em outras pesquisas com objetivos semelhantes, tendo sido obtidos resultados satisfatórios em relação à aceitação dos participantes (BIZERRA, 2009; CERQUEIRA; GENOVA; BIZERRA, 2014; RUFATO; BIZERRA, 2014). 


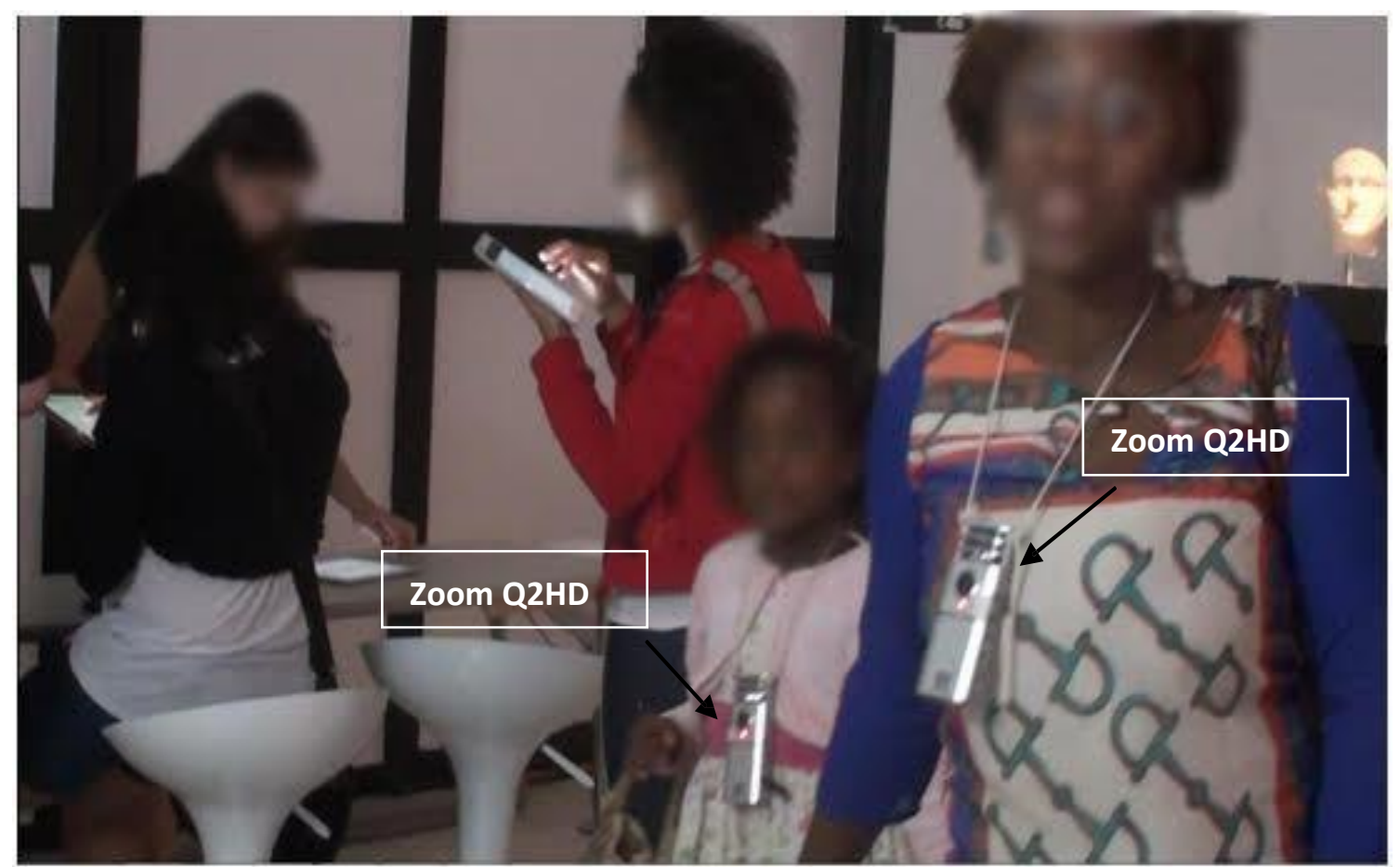

Figura 14 - Participantes da pesquisa (Família - Público espontâneo) em situação de visita à exposição, portando o gravador de áudio e vídeo. Fonte: autoria própria.

A seguir, apresentamos um resumo (QUADRO 4) do contexto de visitação das três famílias participantes da pesquisa para que o leitor possa utilizar como guia durante a leitura do capítulo de análise dos dados.

QUADRO 4. O contexto de visitação das três famílias participantes da pesquisa.

\begin{tabular}{|l|l|l|}
\hline Identificação & Duração & Contexto \\
\hline $\begin{array}{l}\text { Família 1 } \\
\text { Gabriel (filho, 8 anos) }\end{array}$ & $\begin{array}{l}75 \\
\text { minutos }\end{array}$ & $\begin{array}{l}\text { A mãe, da área de biomedicina, } \\
\text { demonstrava ter conhecimento } \\
\text { sobre alguns temas apresentados na } \\
\text { exposição. Buscava guiar o filho } \\
\text { durante a visita e esse demostrou } \\
\text { interesse pela temática universo. Em } \\
\text { diversos momentos questionou qual } \\
\text { o horário que eles iriam embora. }\end{array}$ \\
\hline
\end{tabular}




\begin{tabular}{|l|l|l|}
\hline $\begin{array}{l}\text { Família } 2 \\
\text { Tina (mãe, 45 anos) }\end{array}$ & Antônia (filha, 6 anos) & $\begin{array}{l}\text { A família 2 realizou a visitação em } \\
\text { menor tempo. A mãe procurava } \\
\text { indicar o que seria importante para a } \\
\text { filha, que queria manipular os } \\
\text { objetos que eram apresentados na } \\
\text { exposição. Tina em diversos } \\
\text { momentos reclamou sobre a falta de } \\
\text { tradução em algumas partes da } \\
\text { exposição e também a falta de } \\
\text { monitores para explicações. A mãe } \\
\text { decidiu ir embora após verbalizar } \\
\text { que não estava entendendo o que } \\
\text { era apresentado em um dos } \\
\text { módulos. }\end{array}$ \\
\hline $\begin{array}{l}\text { Família 3 } \\
\text { Isabel (41 anos) } \\
\text { Rafaela (13 anos) } \\
\text { Juliana (11 anos) }\end{array}$ & $\begin{array}{l}\text { A família 3 demonstrou forte } \\
\text { interesse pelos temas apresentados, } \\
\text { os integrantes se revezavam na } \\
\text { função de direcionar o caminho que } \\
\text { seria seguido. As filhas em diversos } \\
\text { momentos questionaram a mãe } \\
\text { sobre assuntos que eram } \\
\text { apresentados. Isabel buscava } \\
\text { dialogar com as filhas sobre o que } \\
\text { era apresentado na exposição, } \\
\text { pedindo o auxílio aos mediadores } \\
\text { quando necessário. }\end{array}$ \\
\hline
\end{tabular}

c) Notas de campo: Ao longo da exposição, foram feitas notas de campo que ajudaram no resgate ou complemento de algumas informações. As observações de campo realizadas foram do tipo "não estruturadas", realizadas de modo que "comportamentos observados não são predeterminados, eles são observados e relatados da forma como ocorrem, visando descrever e compreender o que está 
ocorrendo" (ALVES-MAZZOTTI; GEWANDSZNAJDER, 1998, p. 166). Foram observadas as visitas espontâneas, bem como a ação dos monitores. $O$ foco das observações foi perceber ações e falas que pudessem ajudar no entendimento da percepção desses sujeitos em relação à exposição. Além do objetivo já apresentado, a partir da convivência diária do pesquisador com os sujeitos envolvidos com o Túnel da Ciência, foi possível obter informações que ajudaram a compor o cenário em que a exposição foi realizada.

\subsubsection{Síntese das ferramentas metodológicas}

Como já apresentamos, nossa escolha metodológica de conduzir a pesquisa através de um estudo de caso nos coloca em uma posição de empreender esforços para que as diversas facetas do objeto de estudo sejam contempladas. Para isso, foram empregadas diversas fontes de dados.

Em um cenário em que se estuda um problema complexo que envolve diversas relações sociais é necessário criar um rigor metodológico para organizar, explorar e estudar os dados coletados, tendo como fio condutor o referencial teórico. Tal objetivo representou uma tensão que esteve presente durante toda a pesquisa. No Quadro 5, apresentamos uma síntese das ferramentas que foram utilizadas para compor o nosso grupo de dados, permitindo ter uma dimensão do esforço de pesquisa realizado.

QUADRO 5. Síntese das ferramentas de coleta de dados.

\begin{tabular}{|l|l|}
\hline \multirow{2}{*}{ Ferramentas } & Descrição \\
\hline Entrevistas & Utilizaremos uma entrevista com o representante \\
& do Instituto Max Planck, uma entrevista com o \\
& representante da Produtora Geração, uma \\
& entrevista com o representante do MCTIC, três \\
& entrevistas pré e pós visita com o público \\
& espontâneo e cinco entrevistas com os monitores, \\
& totalizando onze entrevistas e nove horas e 24 \\
& minutos de gravação. \\
\hline
\end{tabular}




\begin{tabular}{|l|l|}
\hline Notas de campo & O pesquisador esteve presente todos os dias em \\
& que a exposição permaneceu no Brasil. A partir \\
& desse contato direto foi possível registrar \\
observações e informações que ajudarão a \\
entender o contexto do Túnel da Ciência e \\
completar dados que não puderam ser obtidos por \\
outras técnicas. \\
\hline Filmagem das visitas & Foram gravadas três visitas do público espontâneo, \\
& totalizando três horas e 45 minutos de gravação. \\
\hline
\end{tabular}

A princípio, o cenário apresentado acima pode representar um caos em termos de informações, por isso, buscamos esforços para organizar tais dados, estruturando a análise em algumas etapas.

\subsection{ORGANIZAÇÃO E ANÁLISE DOS DADOS}

Os dados coletados foram organizados e analisados com base nos elementos apresentados pela perspectiva histórico-cultural, de modo que fosse possível identificar alguns elementos relevantes ao quadro teórico. Dividimos o processo em três etapas: 1 - Leitura e releitura dos dados em busca de agrupamento temático, 2 - Construção da narrativa dos sistemas de atividades e 3 - Identificação das contradições e categorização. Antes de descrever as etapas, porém, abordaremos a utilização do processo de triangulação e o uso da análise textual discursiva.

\subsubsection{Sobre o processo de triangulação}

Para garantir a confiabilidade da análise dos dados, buscou-se aplicar a estratégia de triangulação. Tal medida tem papel muito importante em pesquisas qualitativas, especialmente com dados de observações e entrevistas, nos quais as inferências feitas dependem muito da perspectiva que se tem sobre o que se olha $e$ se ouve (VIANNA, 2007). Para Farmer (2006), a triangulação é um enfoque metodológico que contribui para validade dos resultados de uma pesquisa em que podem ser utilizados múltiplos métodos, teorias, fontes e análises por diferentes 
pesquisadores. Para auxiliar na manutenção da fidedignidade dessa pesquisa, lançamos mão da triangulação de pesquisadores e da triangulação de fontes de dados, que terão papéis importantes na análise apresentada.

A triangulação de dados refere-se ao uso de diferentes tipos de fontes de dados para se construir as reflexões sobre os resultados (DENZIN, 1978; GUION, 2002). Na presente pesquisa, há o uso de dados provenientes de entrevistas, observações e filmagens, com o objetivo de conferir maior consistência às reflexões, sendo uma forma importante de criar um quadro mais abrangente da realidade social das atividades em que o grupo de participantes está inserido.

A triangulação de pesquisadores refere-se ao confronto da análise realizada por mais de um pesquisador; por meio de leituras cruzadas (GUION, 2002; VIANNA, 2007). Nesta pesquisa, tal tipo de triangulação foi utilizada para a análise e categorização dos conteúdos das contradições identificadas, cuja base teórica é apresentada no Capítulo 2. As categorias utilizadas foram repassadas a um outro pesquisador que, juntamente com o pesquisador-autor, compararam as categorizações e discutiram sobre os pontos divergentes até se obter consenso.

\subsubsection{Sobre a análise textual discursiva}

Temos na perspectiva histórico-cultural os elementos-chave para a definição das contradições dialéticas, entendemos que são fornecidos elementos metodológicos para identificação da sua manifestação e, assim, os dados coletados foram submetidos a um processo de análise textual discursiva, tal como o proposto por Moraes (2003). A análise centra-se nos dados das transcrições das filmagens das visitas e das entrevistas. As falas transformadas em texto constituem o corpus da pesquisa. A análise textual discursiva foi assim descrita, brevemente, pelo seu autor:

[...] pode ser compreendida como um processo auto organizado de construção de compreensão em que novos entendimentos emergem de uma sequência recursiva de três componentes: desconstrução dos textos do corpus, a unitarização; estabelecimento de relações entre os elementos unitários, a categorização; o captar do novo emergente em que a nova compreensão é comunicada e validada (MORAES, 2003, p.192).

Esse método de análise envolve três importantes etapas: a unitarização, a categorização e a expressão do novo emergente. Descrevemos a seguir as etapas 
propostas por Moraes (2003).

A unitarização caracteriza-se por uma leitura aprofundada dos dados, a partir da qual ocorre a desconstrução do corpus e a busca por unidades de análises em um movimento de separação. Segundo Moraes e Galiazzi (2006), os dados são "recortados, pulverizados, desconstruídos, sempre a partir das capacidades interpretativas do pesquisador (p. 132)".

A categorização é compreendida como um "processo de comparação constante entre as unidades definidas no processo inicial de análise, levando ao agrupamento de elementos semelhantes (MORAES, 2003, p. 197)". Como afirmam Moraes e Galiazzi (2006),

[...] as categorias não saem prontas, e exigem um retorno cíclico aos mesmos elementos para sua gradativa qualificação. $O$ pesquisador precisa avaliar constantemente suas categorias em termos de sua validade e pertinência (p. 125).

O processo de unitarização e categorização resulta em um novo emergente que se concretiza no metatexto. Segundo Moraes (2003),

[...] os metatextos são constituídos de descrição e interpretação, representando o conjunto um modo de compreensão e teorização dos fenômenos investigados. A qualidade dos textos resultantes das análises não depende apenas de sua validade e confiabilidade, mas é, também, conseqüência do pesquisador assumir-se como autor de seus argumentos (p. 202).

A análise buscou identificar os sistemas de atividades e identificar suas formas de organização e interações. Posteriormente, focando em sistemas de significação da exposição, foram analisados os discursos dos sujeitos entrevistados, em termos de contradições e modificações nos sistemas, analisando, assim, os conteúdos das contradições que envolvem o caso analisado. A seguir, apresentamos em detalhes as etapas de organização e análise dos dados:

\section{a) Etapa 1 - Leitura e releitura dos dados em busca de agrupamentos temáticos}

Compreender as complexas interações humanas a partir da teoria históricocultural da Atividade muitas vezes envolve um grande conjunto de dados, análises complexas e o enfrentamento de dificuldades para apresentação dos resultados, o que pode gerar complicações para a condução da pesquisa (COLLINS et al 2004; HOADLEY 2004). Também pode ser difícil para os pesquisadores coordenarem os 
vários níveis de análises necessários para se chegar a conclusões significativas de seu trabalho (COBB et al., 2003).

Segundo Yamagata-Lynch (2010), os pesquisadores que buscam estudar os sistemas de atividades devem utilizar as perguntas dos seus estudos, os aportes teóricos e suas experiências como observadores como uma lente para identificar os temas predominantes nos transcritos. Neste processo, podem ser identificados e organizados temas e subtemas relacionados com o contexto do estudo questão. $O$ esforço de pesquisa na organização destes agrupamentos permite, mais facilmente, fornecer evidência para construções das narrativas e discussões, promovendo a apropriação dos dados e mantendo um equilíbrio entre a experiência com os participantes e o conhecimento teórico. Para facilitar esse processo utilizamos, nesse estudo, um software de gerenciamento de pesquisas qualitativas.

Há algumas décadas, a área de pesquisa em Ciências Humanas vem explorando os avanços tecnológicos que permitiram o desenvolvimento de softwares que auxiliam o pesquisador na organização e análise de uma gama variada de dados.

Hoje, diversos softwares podem ser utilizados para, dentre outras funções, auxiliar na transcrição de entrevistas, análise de vídeos, imagens, documentos etc. Além disso, o corpus de dados, após organizado, pode ser submetido desde análises simples de frequência de palavras até mapas de conexão. No estudo que apresentamos nesta tese, o grande desafio era promover a organização de uma grande quantidade de informações e estabelecer relações entre as atividades que emergiram das análises.

Inicialmente, para o desenvolvimento da tese optamos pelo uso do software WebQDA, porém, devido a mudanças dentro da empresa, o serviço deixou de ser oferecido temporariamente. Perante tal fato, mais recentemente iniciamos o uso do NVIVO11®, que se propõe a atingir objetivos semelhantes. Esse processo de aprofundamento em relação ao uso do programa foi realizado coletivamente pelo nosso grupo de pesquisa e, assim, durante as reuniões procedemos com a exploração dos recursos disponibilizados pelo programa, processo ainda em andamento.

Acredito ser fundamental destacar que quaisquer programas são somente facilitadores do processo analítico dos dados e não substituem a responsabilidade do pesquisador na interpretação substantiva dos resultados. Para Mitchell (1967), 
uma das vantagens na utilização de ferramentas computacionais consiste no aumento da velocidade e na redução do custo de digitalização de grandes volumes de textos. Similarmente, Caterall (1996) defende que o uso desses programas aumenta a produtividade, sobretudo quando se trabalha com grandes bases de dados. Em síntese, a principal crítica é que o trabalho pode ser direcionado pelas facilidades computacionais do software e não orientado pela teoria (BLISMAS; DAINTY, 2003; WICKHAM e WOODS, 2005).

O NVIVO $11 \AA$ foi utilizado nessa pesquisa para a codificação dos dados, assim, as entrevistas dos participantes e a filmagem das visitas foram transcritas na íntegra. Os arquivos foram inseridos no programa, conforme a figura abaixo:

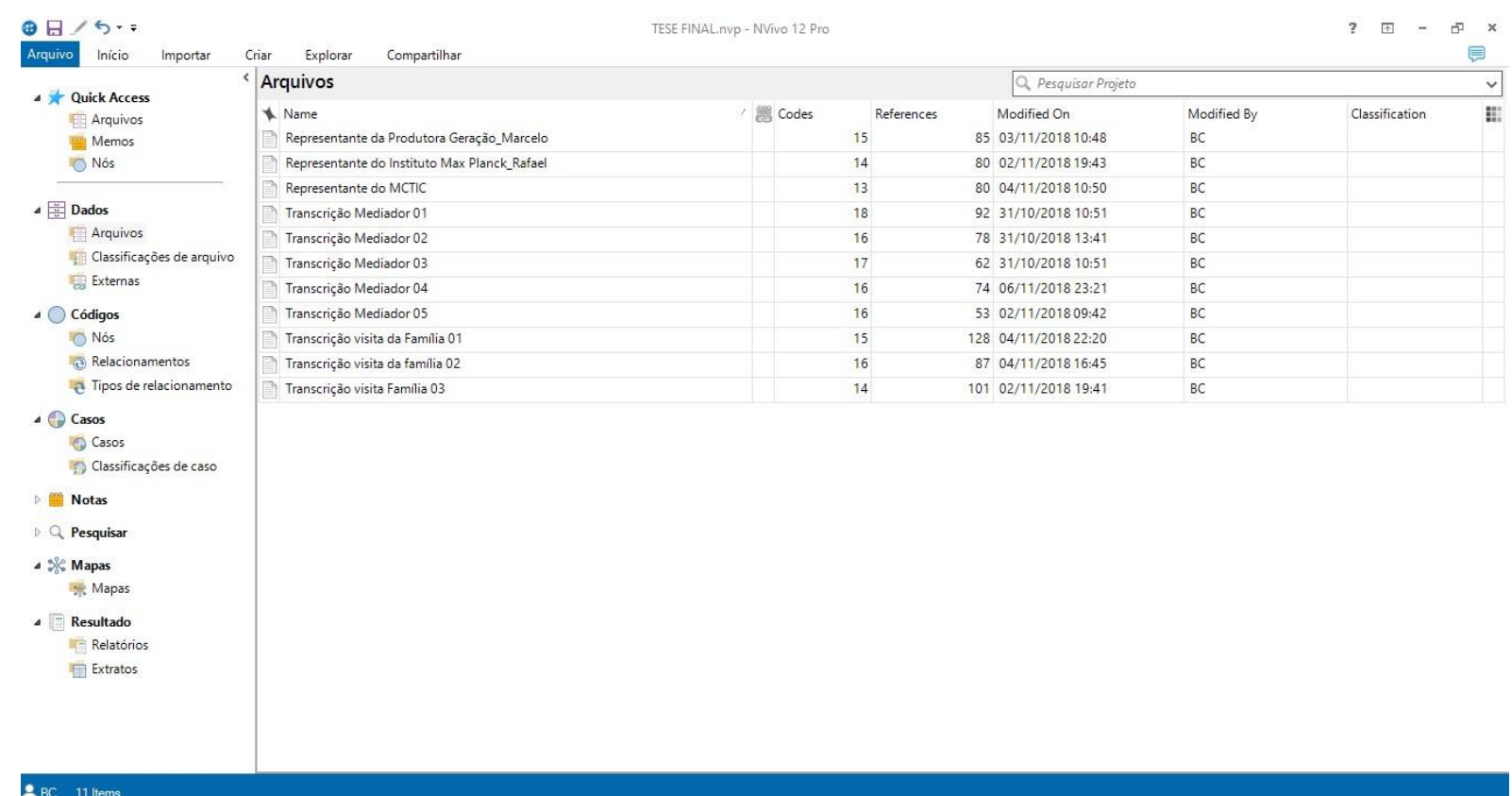

Figura 15 - Arquivos das transcrições e visitas inseridos no software NVIVO11®.

Fonte: autoria própria.

Após a inserção dos arquivos, procedeu-se a separação dos transcritos em agrupamento temáticos.

Cada participante foi inserido no programa como um nó, que é uma das funcionalidades do NVIVO11®. Cada nó pode ser entendido como um conjunto e cada subnó como um subconjunto. Como apresentado na imagem abaixo (Figura 16), os participantes foram divididos em nós diferentes facilitando, assim, um posterior acesso. No exemplo apresentado, é possível localizar, à direita, a transcrição da entrevista com o Representante do MCTIC e, à esquerda, o seu 
discurso separado em temáticas (subnós).

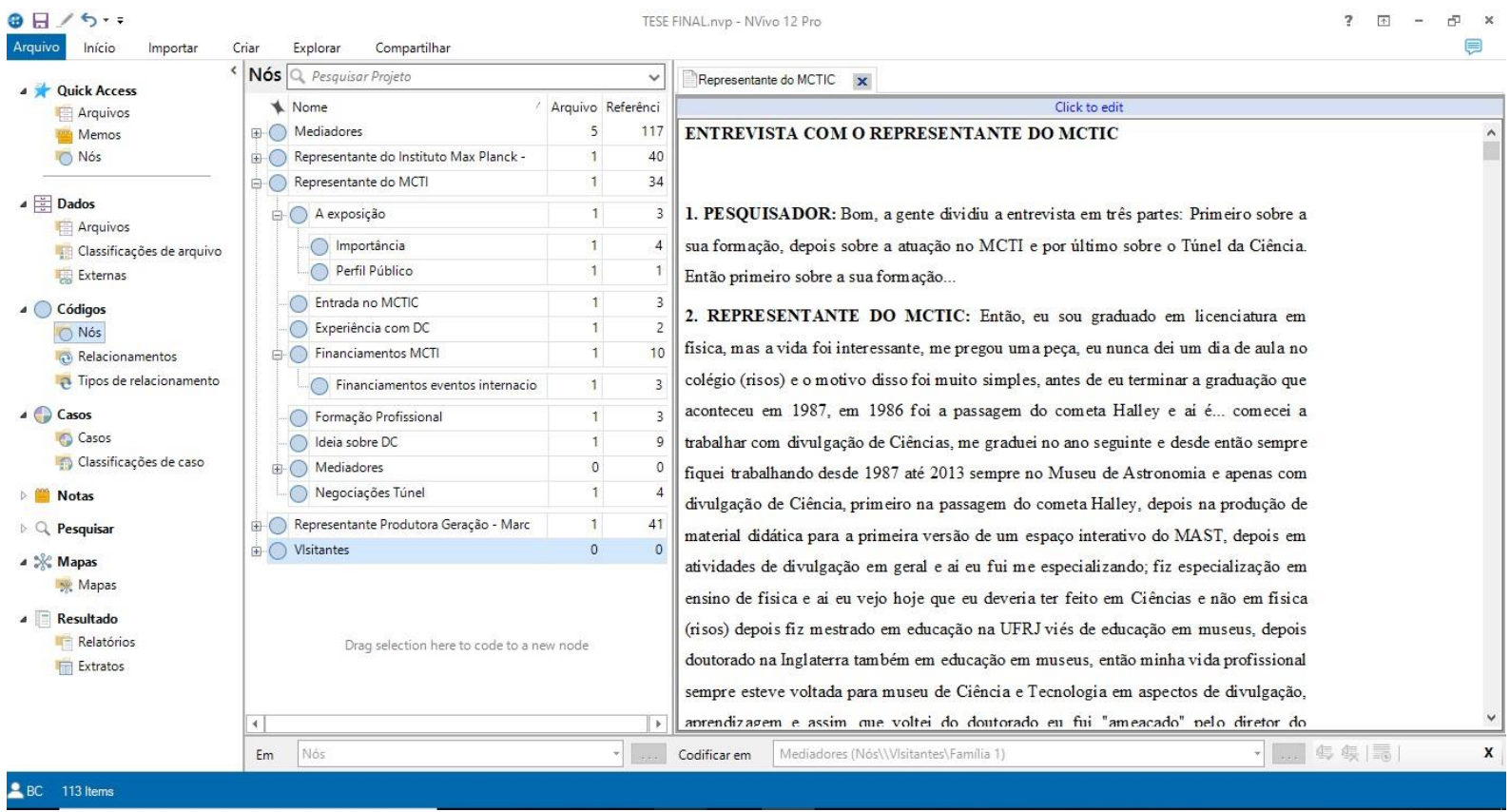

Figura 16 - Divisão da transcrição do Representante do MCTIC em agrupamentos temáticos (subnós). Fonte: autoria própria.

Os transcritos foram lidos e separados em agrupamentos temáticos, permitindo a reunião de trechos que abordavam o mesmo tema. Foi possível identificar cinco grandes temas: monitoria, a exposição, visitação, Ciências e institucional. Em cada um desses grupos temáticos foram elencados alguns subgrupos, conforme apresentado no quadro 6 abaixo:

QUADRO 6. Agrupamentos e subagrupamentos temáticos

\begin{tabular}{|l|l|l|l|l|}
\hline Monitoria & A exposição & Visitação & Ciências & Institucional \\
\hline $\begin{array}{l}\text { Atuação dos } \\
\text { monitores }\end{array}$ & $\begin{array}{l}\text { A estrutura } \\
\text { da exposição }\end{array}$ & $\begin{array}{l}\text { Atividades } \\
\text { relacionadas } \\
\text { à Ciência }\end{array}$ & $\begin{array}{l}\text { Ciência e } \\
\text { política }\end{array}$ & $\begin{array}{l}\text { Atuação do } \\
\text { Max Planck }\end{array}$ \\
\hline $\begin{array}{l}\text { Estratégias } \\
\text { de monitoria }\end{array}$ & $\begin{array}{l}\text { Ciências } \\
\text { apresentadas }\end{array}$ & $\begin{array}{l}\text { Cotidiano dos } \\
\text { visitantes }\end{array}$ & $\begin{array}{l}\text { Ciência } \\
\text { universal e } \\
\text { local }\end{array}$ & $\begin{array}{l}\text { Financiamentos } \\
\text { do MCTIC }\end{array}$ \\
\hline $\begin{array}{l}\text { Preparação } \\
\text { dos } \\
\text { monitores }\end{array}$ & $\begin{array}{l}\text { Expectativas } \\
\text { em relação à } \\
\text { exposição }\end{array}$ & Visitas a & $\begin{array}{l}\text { Modelos de } \\
\text { museus }\end{array}$ & $\begin{array}{l}\text { Formação } \\
\text { dialógico } \\
\text { profissional }\end{array}$ \\
\hline
\end{tabular}




\begin{tabular}{|c|c|c|c|c|}
\hline $\begin{array}{l}\text { Mudanças na } \\
\text { monitoria }\end{array}$ & Interatividade & $\begin{array}{l}\text { Dificuldades } \\
\text { na visitação }\end{array}$ & $\begin{array}{l}\text { Ciência } \\
\text { brasileira e } \\
\text { alemã }\end{array}$ & $\begin{array}{l}\text { Experiência } \\
\text { com DC }\end{array}$ \\
\hline $\begin{array}{l}\text { Papel do } \\
\text { monitor }\end{array}$ & $\begin{array}{l}\text { Importância } \\
\text { da exposição }\end{array}$ & $\begin{array}{l}\text { Estratégias } \\
\text { de visitação }\end{array}$ & $\begin{array}{l}\text { Objetivos da } \\
\text { divulgação } \\
\text { das Ciências }\end{array}$ & $\begin{array}{l}\text { Negociações } \\
\text { para vinda da } \\
\text { exposição }\end{array}$ \\
\hline \multirow{4}{*}{$\begin{array}{l}\text { Motivação } \\
\text { inicial para } \\
\text { atuar como } \\
\text { monitor }\end{array}$} & $\begin{array}{l}\text { Adaptações } \\
\text { do Túnel da } \\
\text { Ciência }\end{array}$ & $\begin{array}{l}\text { Recursos } \\
\text { utilizados na } \\
\text { visitação }\end{array}$ & $\begin{array}{l}\text { Pesquisa } \\
\text { básica e } \\
\text { aplicada }\end{array}$ & $\begin{array}{l}\text { Experiências } \\
\text { da Produtora } \\
\text { Geração }\end{array}$ \\
\hline & $\begin{array}{l}\text { Objetivos do } \\
\text { Túnel da } \\
\text { Ciência }\end{array}$ & $\begin{array}{l}\text { Público } \\
\text { escolar }\end{array}$ & & $\begin{array}{l}\text { Governo } \\
\text { brasileiro }\end{array}$ \\
\hline & $\begin{array}{l}\text { Idioma da } \\
\text { exposição }\end{array}$ & $\begin{array}{l}\text { Perfil do } \\
\text { público }\end{array}$ & & \\
\hline & $\begin{array}{l}\text { Divulgação } \\
\text { da exposição }\end{array}$ & & & \\
\hline
\end{tabular}

O software possibilita que o pesquisador visualize em um determinado agrupamento temático os trechos classificados (intitulados no programa como referências), conforme apresentado na figura 17. Essas funcionalidades auxiliam o pesquisador no processo de verificação e separação feito inicialmente, possibilitando a quantificação e modificação, se necessário. Essas funcionalidades permitiram o acesso aos dados com maior agilidade. 


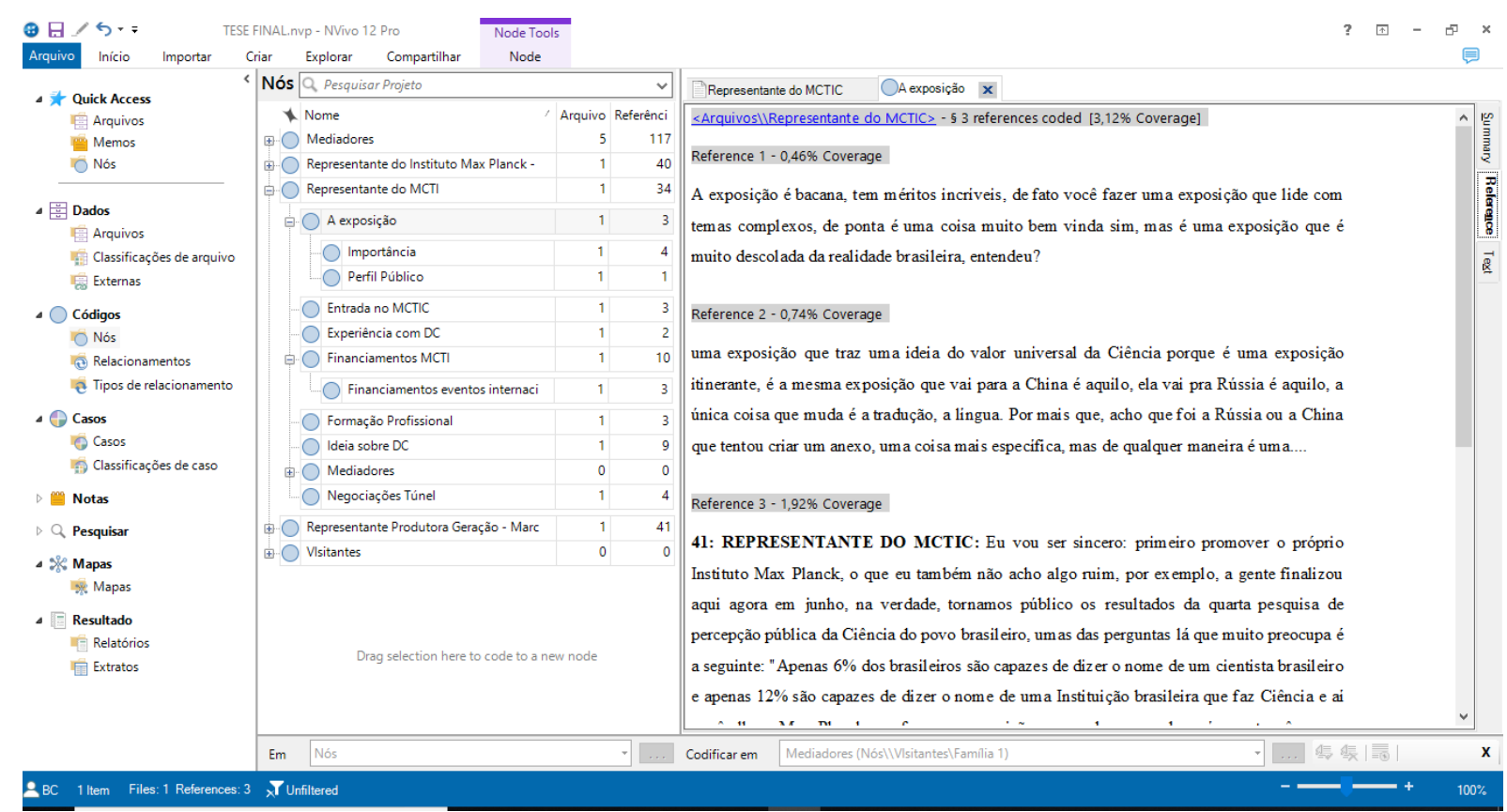

Figura 17 - Trechos do discurso (Referências) do Representante do MCTIC agrupado no subnó "A exposição". Fonte: autoria própria.

A grande funcionalidade do programa explorada nesse estudo foi sua capacidade de organização dos dados, permitindo que o pesquisador tivesse acesso aos trechos que correspondiam à temática que iria ser analisada, facilitando a construção das narrativas.

b) Etapa 2 - Construção das narrativas dos sistemas de atividades dos participantes

$\mathrm{Na}$ Etapa 2, procedeu-se com a identificação dos sistemas de atividades e construção de narrativas que expressassem as experiências dos participantes.

Como apontado no referencial teórico, a unidade de análise do presente método é o sistema de atividade em si incorporada a seu contexto social (ENGESTRÖM 1987; ROGOFF 1995; WERTSCH 1991). Assim sendo, busquei focar a análise na identificação dos sistemas de atividades que eram essenciais e relevantes para esta pesquisa. Segundo Yamagata-Lynch 2007, para garantir que os pesquisadores identifiquem as unidades de análises apropriadas, eles precisam examinar cuidadosamente as atividades relacionadas com as questões de estudo. Foram esboçados, então, alguns modelos de sistemas de atividades baseados nos elementos dos sistemas de atividades apresentados no Capítulo 2. As unidades de atividades foram identificadas seguindo as tendências históricas em torno das 
interações entre participantes.

Conforme aponta Yamagata-Lynch (2010) em seus estudos, essa etapa envolve a elaboração e reformulação de seus sistemas de atividade e continua a medida que a análise de dados evolui. Durante este processo de refinação, os investigadores precisam se perguntar se o conjunto de sistemas de atividades definidos irá ajudá-los a responder a sua pergunta e se são capazes de encontrar implicações sistêmicas de suas conclusões.

Partindo desses pressupostos, foi desenvolvida uma descrição densa que ajudasse o leitor a obter um panorama geral do conjunto de atividades que compõe esse estudo. A organização dos grupos temáticos da etapa anterior auxiliou a colocar foco no processo de desenvolvimento da narrativa, facilitando o acesso à informação que era relevante e essencial para as questões de pesquisa. A preparação das narrativas me apresentou a uma nova etapa de análise, em que eu era capaz de voltar a perceber as experiências dos participantes a partir de uma perspectiva de pesquisador e encontrar informações importantes sobre as mudanças que ocorreram nos sistemas de atividade. Nessa etapa, também foi possível identificar e relatar as interações entre os sistemas de atividades, preparando o caminho para a localização da manifestação das contradições.

\section{c) Etapa 3 - Identificação das contradições e categorização}

Ao passo que os sistemas de atividades vão sendo elaborados, é possível começar a identificar as relações entre as atividades e as implicações sistêmicas. Esse processo envolve idas e vindas para examinar unidades únicas e múltiplas de atividades.

Segundo Engeström (1996), as contradições presentes nos sistemas de atividades e a natureza de cada componente individual podem criar tensões dentro de um sistema e entre sistemas de atividades. As tensões surgem das influências que as contradições sistêmicas têm sobre um sistema de atividade e podem afetar as interações entre componentes do mesmo. As tensões podem afetar também a capacidade do sujeito para alcançar o objeto, representando um obstáculo. Ao identificar contradições e tensões que afetam vários sistemas de atividades, os pesquisadores são capazes de demonstrar e discutir as mudanças contextuais que conduziram às transformações nos sistemas de atividade estudados.

Nessa investigação, a identificação das contradições e tensões envolveu um 
longo processo de análise e impregnação dos dados e foi baseada nas características das contradições dialéticas e nas suas formas de manifestações apresentadas no Capítulo 2. A identificação e categorização dos conteúdos dessas contradições, ou seja, os seus motivos, resultou em categorias aglutinadoras que serão abordadas adiante são: Ciência local x Ciência global, financiamento público $x$ privado, aprender conteúdos científicos $x$ explorar os aparatos interativos, divulgação institucional $x$ divulgação das ciências, modelos dialógicos $x$ valores universais, interatividade discurso midiático $\mathrm{x}$ discurso expositivo, negociações entre 0 planejado $x$ efetivado, formalização institucional da concepção de DC $x$ instabilidade política, teoria $x$ prática de monitoria, monitoria junto ao público escolar $\mathrm{x}$ monitoria junto ao público espontâneo. 


\section{CAPÍTULO 4. OS SISTEMAS DE ATIVIDADES EM QUESTÃO}

Analisar a exposição "Túnel da Ciência 3.0" é um problema de pesquisa complexo por envolver vários sujeitos desempenhando diferentes atividades. Ao mesmo tempo, tal cenário é extremamente frutífero para a abordagem da perspectiva Histórico-Cultural da Atividade, que tem como unidade de análise as atividades humanas e suas relações.

No pensamento de Vygotsky, podemos encontrar a base necessária para o entendimento dessas relações que se desdobram a nossa frente, revelando contradições dialéticas e seus modos de significação pelos sujeitos, bem como formas de superação.

Baseando-se nessas ideias, podemos enxergar a análise dos dados como uma construção que ao longo do tempo foi se estruturando à medida que o pesquisador também se moldava, ou seja, essa metodologia foi se solidificando na prática, em conformidade com as ideias de Vygotsky. Segundo o autor "o método, ou seja, o caminho seguido, é visto como um meio de cognição: mas o método é determinado pelo objetivo que conduz. Por isso a prática reestrutura toda a metodologia da ciência" (2004, p. 346).

Tendo em vista esses apontamentos, de modo sintético, a análise irá percorrer o discurso dos sujeitos entrevistados, apoiada pelas observações do pesquisador e pelas filmagens das visitas das famílias.

A primeira etapa, como já citado, é caracterizar as atividades dos participantes, identificando o objeto ao qual a atividade está sendo direcionada, criando, a partir disso, uma narrativa que contemple as experiências dos participantes.

A segunda etapa compreende a identificação e categorização das contradições presentes nessas atividades e na relação entre os sistemas de atividades, tendo como base as categorias apresentadas no Capítulo 2. Durante essas etapas, serão discutidas as interações estabelecidas entre os sistemas de atividades, permitindo uma visão mais holística, sendo possível também, identificar os conteúdos e as formas de superação das contradições, pois apenas por meio da "análise das contradições e da dinâmica das relações sociais, ou seja, através do método marxista, seria possível enxergar além das aparências" (TULESKI, 2008, p. 118). 


\subsection{ATIVIDADE CENTRAL: UM OBJETO COMPARTILHADO}

Entendemos como Atividade Central aquela que é compartilhada entre todos os sujeitos envolvidos com a vinda da exposição "Túnel da Ciência 3.0" ao Brasil.

$\mathrm{Na}$ Atividade Central (Figura 18), os diferentes participantes da pesquisa estão direcionando suas atividades a um objeto que é a Cultura Científica, em vista da Promoção da Cultura Científica. Para realização dessa Atividade, são definidas regras tanto pelos sujeitos como pelos pressupostos presentes na composição dos valores das instituições participantes. Por meio da divisão do trabalho, são atribuídas responsabilidades aos sujeitos que se utilizam de instrumentos para realização da Atividade. Todo esse processo está relacionado com a comunidade que faz parte do sistema.

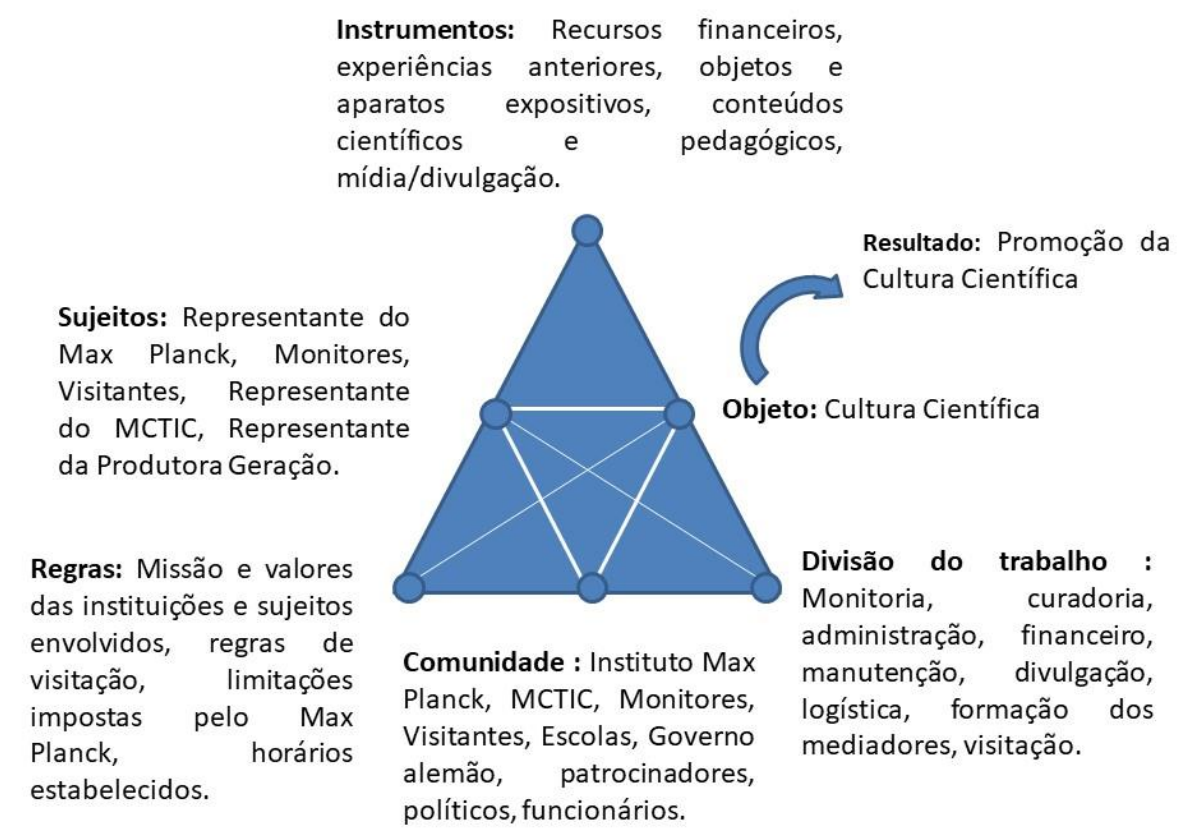

Figura 18 - Atividade Central. Fonte: autoria própria.

Identificada a Atividade Central é importante averiguar as atividades periféricas como forma de compreender o todo.

Abaixo (Figura 19), apresentamos um esquema com os possíveis sistemas de atividades presentes nesse processo de vinda da exposição ao Brasil, compondo um quadro de atividades que expõe a interação entre elas e a atividade central. 


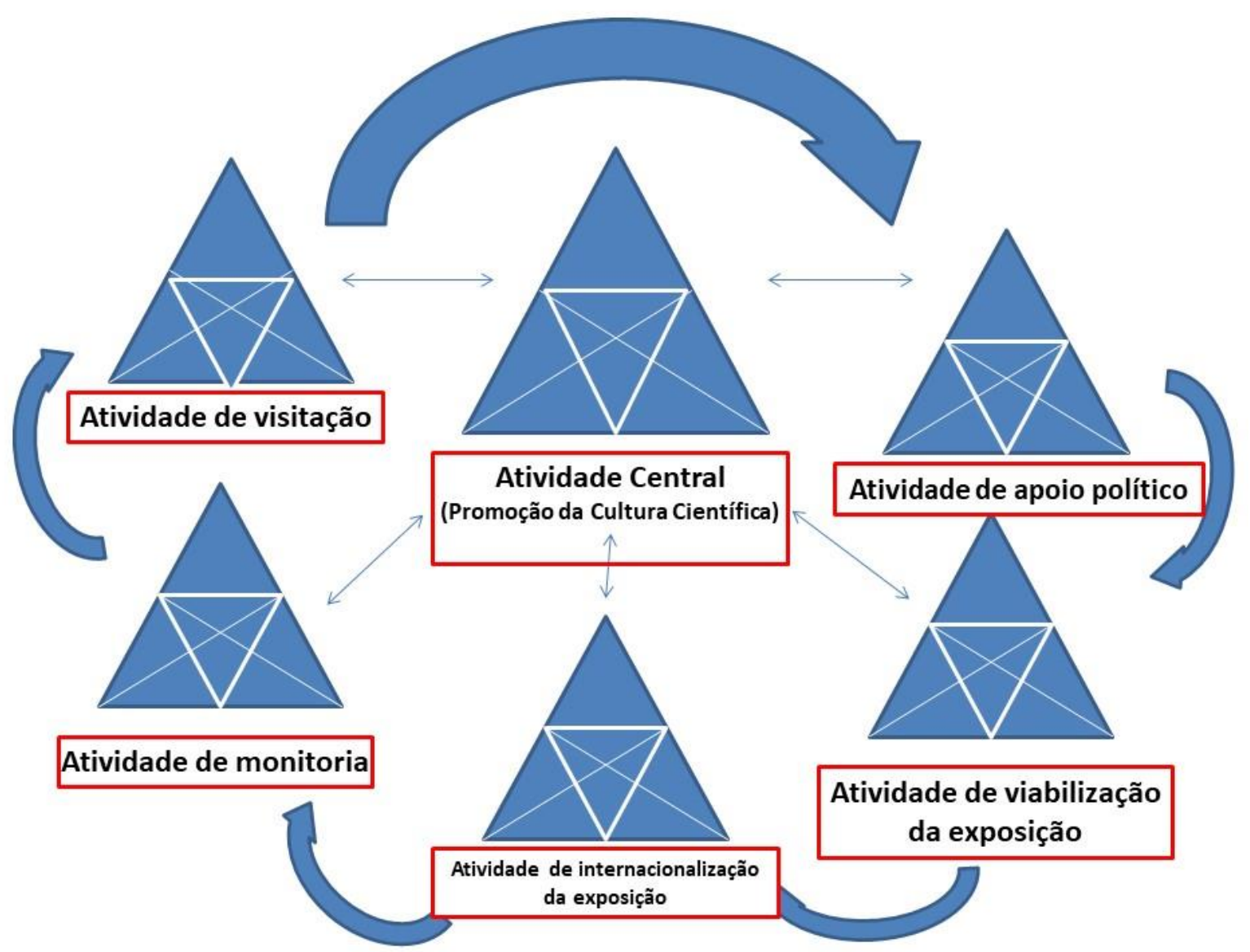

Figura 19 - Possibilidade de leitura das interações entre a Atividade Central e as periféricas. Fonte: autoria própria.

A Atividade Central seria aquela que regeria as outras atividades daquele indivíduo (LEONTIEV, 2009). É possível compreendê-la, ainda, como a atividade emergente a partir de outras atividades dos sujeitos. Nesta pesquisa, identificamos o sistema de atividade Promoção da Cultura Científica como comum a todos os participantes, os quais possuem suas próprias atividades que denominaremos como periféricas.

No esquema apresentado na Figura 19, constam os seguintes sistemas de atividades periféricas: Atividades de visitação (público espontâneo), Atividade de monitoria (profissionais que atuaram na monitoria da exposição), Atividade de viabilização do Túnel da Ciência no Brasil (sob responsabilidade da Produtora Geração), Atividade de internacionalização da exposição (operada pelo Instituto Max Planck) e de apoio político (MCTIC).

É importante ressaltar que as atividades periféricas estão interligadas tanto entre elas como com a Atividade Central. Nessa interação, é possível que surjam 
tensões e contradições que movimentam os sistemas. Como vimos no capítulo 2, as contradições de quarta ordem ocorrem entre o sistema de atividade central e os sistemas de atividades circunvizinhos na rede de sistemas e emergem da interação da atividade central com as atividades periféricas. Elas se manifestam, principalmente, na resistência entre os sistemas de atividades no processo de executar a atividade central.

O objetivo das próximas sessões vai além de apresentar os sistemas de atividades. Como já discutimos, esses esquemas buscam retratar uma "foto" do contexto investigado pelo pesquisador. Assim, apesar de ser um importante recurso, a discussão precisa ser focada no movimento que está intimamente ligado às contradições. Buscamos, portanto, na descrição e análise dos sistemas de atividades, primeiro contextualizar a experiência dos participantes, a fim de situar o leitor sobre os cenários que estavam em interação no caso estudado. Com isso, o leitor, poderá perceber qual a relação de um sistema de atividade com os demais. A partir dessa compreensão, poderemos ao final refletir sobre as raízes das contradições que propiciaram os movimentos dessas atividades.

A seguir, apresentamos a análise das seguintes atividades: internacionalização da exposição, apoio político, visitação, monitoria e viabilização do Túnel da Ciência no Brasil.

Para além disso, é preciso olhar a relação dessas atividades com a Atividade Central. Para isso, propõe-se que o processo histórico de construção multifacetada e coletiva do objeto passe a ser elemento analítico e organizador em uma primeira aproximação em direção ao cenário empírico. Logo, é importante entender como os participantes percebem o objeto da atividade.

\subsection{INTERNACIONALIZAÇÃO DA EXPOSIÇÃO}

O Instituto Max Planck vem desenvolvendo o Túnel da Ciência desde os anos 2000, quando foi lançada a primeira versão da exposição. De lá para cá, foram desenvolvidas outras duas versões, que mantiveram a ideia principal, porém, se diferenciaram em relação às pesquisas que estruturam o discurso expositivo e aos aparatos que foram apresentados ao público.

Como a exposição é itinerante e internacional, a concepção e a exibição da mostra incorporam elementos relacionados ao processo de internacionalização. 
Assim, a cada país visitado é necessário que os profissionais do Instituto Max Planck auxiliem no desenvolvimento da exposição, montagem, estabelecimento de contatos políticos, entre outras ações.

Em cada país essa atividade toma uma forma diferente, com a incorporação ou supressão de elementos resultantes das especificidades locais. No Brasil, por exemplo, os profissionais do Instituto Max Planck atuaram na formação dos monitores, traduziram parte dos painéis, realizaram a montagem, orientaram quanto a manutenção da exposição, realizaram algumas atividades burocráticas e tiveram participação na busca por recursos financeiros. Esses dois últimos pontos, segundo eles, deveriam ser desenvolvidos pelo governo brasileiro, o que mostra um desacordo com a divisão de trabalho.

A caracterização da atividade do Instituto Max Planck, no contexto da internacionalização do Túnel da Ciência, está representada na Figura 20, que evidencia os elementos constituintes. A sistematização auxilia nas reflexões sobre as tensões presentes nessa atividade e em relação aos outros sistemas de atividades, revelando contradições.

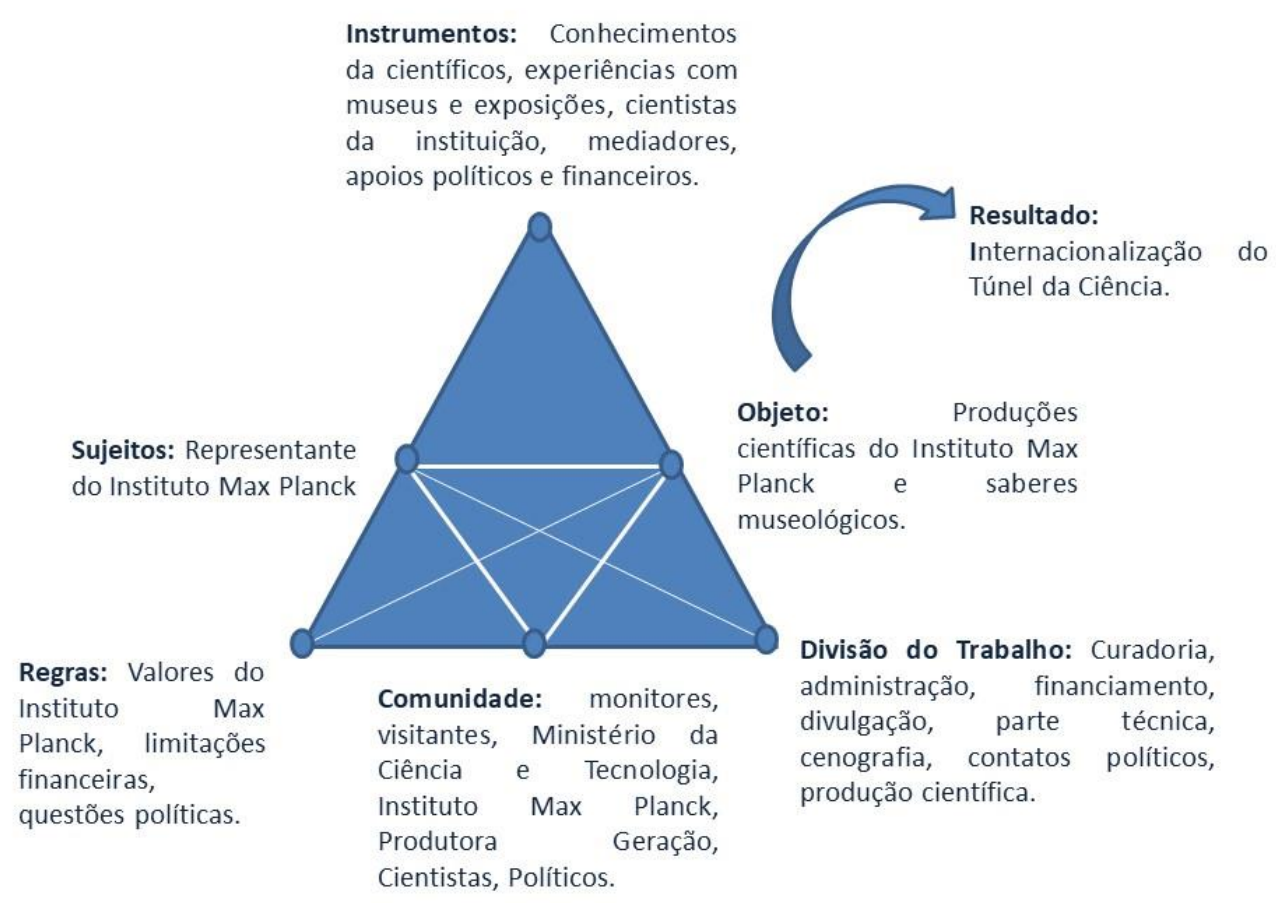

Figura 20 - Caracterização da atividade do Instituto Max Planck. Fonte: autoria própria.

Para identificar o objeto em transformação dessa atividade, foi necessário 
buscar no discurso do representante da instituição falas que representassem suas motivações e necessidades, bem como seu entendimento sobre o seu próprio papel e o trabalho que estava sendo realizado. Abaixo, apresentamos um trecho que serviu de base para nossa análise:

Trecho 32 - Rafael: (...), e o túnel ciência tem apresentado o resultado da pesquisa da Sociedade Max Planck. E este foi o início da história de sucesso. Estamos aqui em uma espécie de um fim, ou de um processo em andamento.

O representante do Instituto Max Planck ressalta que o conteúdo apresentado na exposição corresponde a resultados das pesquisas dos cientistas da instituição e, como afirma o slogan da exposição, seu impacto em alguns anos. A partir da ação direcionada a esses objetos, os responsáveis conseguem conceber e desenvolver o Túnel da Ciência, sempre embasados em seus valores institucionais e nas suas concepções de Ciência, sendo importante ressaltar que na relação com os outros sistemas de atividades, esses elementos se mostraram bastante relevantes, inclusive ditando as regras de trabalho dos outros participantes, por exemplo, no caso da forma de atuação dos monitores.

Buscando compreender a estrutura da atividade, cabe identificar como 0 Instituto Max Planck enxerga a cultura científica enquanto objeto de uma atividade que visa como resultado a significação da exposição.

Trecho 100 - RAFAEL: Se nós formos capazes de encontrar um grande número de visitantes, se houver bastante divulgação, uma palestra para o público sobre o assunto. Isto já é alguma coisa. Queremos ser o pontapé inicial para alguém que poderá se tornar um cientista ou ter uma carreira de futuro. E este é um início para Max Planck. Se alguém está vendo algo que poderia funcionar para ele ou para ela e após anos e anos isso se desdobrar em algo. Em outras palavras, poderia haver um pontapé inicial e a pessoa nem saberia onde tudo começou.

Nessa atividade, as principais tensões se localizam no processo de internacionalização do Túnel da Ciência que está relacionado também com os sistemas de atividades dos outros participantes. Assim, na busca por esse movimento de internacionalização, a instituição se depara com conflitos e contradições que, em alguns casos, são superados e em outros não, como abordaremos com mais detalhes no capítulo 5 .

\subsection{APOIO POLÍtICO - AS TENSÕES NAS RELAÇÕES ENTRE}




\section{INSTITUIÇÕES}

Ao analisar a entrevista do Tiago, Representante do antigo Departamento de Difusão e Popularização da Ciência e Tecnologia do Ministério da Ciência, Tecnologia, Inovação e Comunicação (MCTIC), buscamos caracterizar e esquematizar a atividade predominante no discurso do representante da instituição e relacioná-la com o contexto da vinda do Túnel da Ciência ao Brasil (Figura 21).

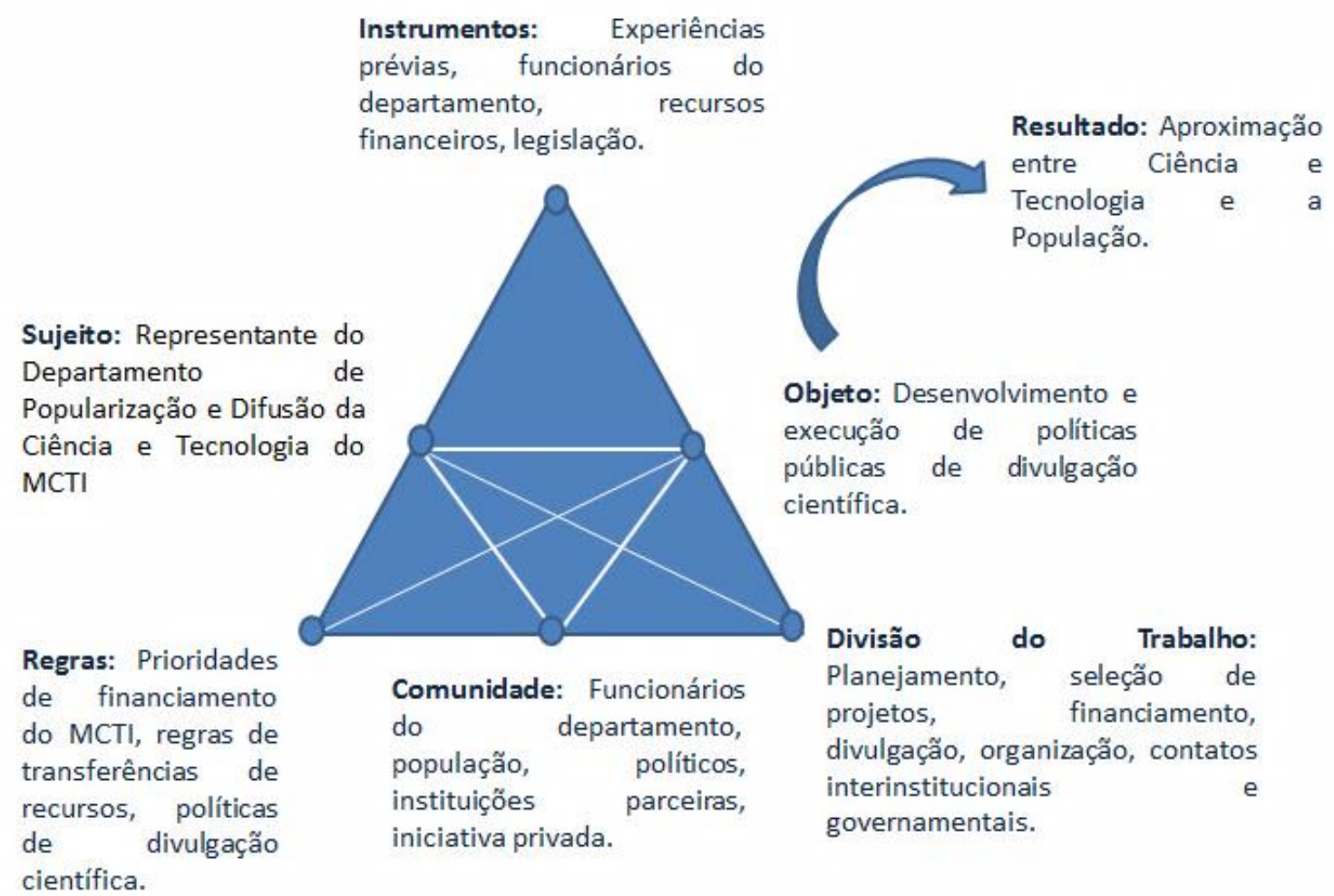

Figura 21 - Caracterização da atividade do Departamento de Popularização e Difusão da Ciência e Tecnologia do MCTI (DEPDI/MCTI). Fonte: autoria própria.

Entendemos que a atividade do DEPDI/MCTIC está direcionada ao desenvolvimento e execução de políticas públicas de divulgação científica que possam resultar em uma aproximação entre C\&T e sociedade, conforme o trecho abaixo:

Trecho 10 - TIAGO: (...) meu amigo... José Ribamar, ele finalizou no final de 2014, uma tese de doutorado que é muito bacana, ele faz um levantamento de percepção entre pessoas que trabalham com divulgação de Ciências no Brasil a respeito de uma política pública de Ciência e Tecnologia, né, na verdade, ele está interessado em saber se na percepção desses divulgadores de Ciências dessas instituições, se o Brasil teria algo que poderia ser classificado como uma política de Ciências e Tecnologia e a resposta foi sim e boa 
parte dessa percepção positiva ela tem como referência as ações do departamento de popularização. (...) então o departamento foi criado em 2003. Mas numa primeira versão ainda muito dirigida para escolas, se eu não estou enganado durante os 18 primeiros meses 0 nome do Departamento era Divulgação de Ciências nas escolas e é uma coisa importante mas muito limitada, quando o professor Ildeu chegou no departamento ele, acho que foi uma das primeiras coisas que ele fez, promoveu uma ampliação da própria missão do departamento. Claro que continuou interagindo com as escolas, mas ampliou para a sociedade em geral. Então o MCTI quando criou a SECIS ${ }^{25}$ rapidamente evoluiu, e evoluiu no sentido de se diferenciar, para entender que em um projeto de uma política nacional de Ciências. O MCTI deveria ter uma área específica para promover esse encontro entre o conhecimento em Ciência e Tecnologia, né, os processos em Ciência e Tecnologia e o público leigo. Então, assim, nesse objetivo, o Departamento é a área do MCTI que encarna essa missão, particularmente é a SECIS e dentro dela o DEPDI, entendeu? E a missão ela acaba se materializando pela entrega de algumas ações à população.

Identificamos, a partir do trecho acima, que as ações e motivos que compunham essa atividade foram mudando ao longo do tempo, em vista de se ampliar os efeitos da atividade. Podemos entender que os projetos de divulgação científica apoiados pelo MCTIC são ações dentro dessa atividade de aproximação entre Ciência, Tecnologia e sociedade. Assim, podemos pontuar que o apoio político e financeiro realizado em favor da vinda do Túnel da Ciência ao Brasil é mais uma das ações da atividade esquematizada na Figura 21.

Para a execução dos financiamentos existem regras que abragem as prioridades da destinação dos recursos, as normas de transferência financeira entre insituições, norteadas pelos projetos de políticas públicas já existentes no Ministério.

Trecho 20 - Tiago: [...] eu diria que hoje no departamento um "metabolismo basal", menos que isso está morto né, então o que é o mínimo né? É o edital de Feiras, o edital de Olimpíadas e a Semana Nacional de Ciência e Tecnologia, isso é o basal só que todo ano a gente tenta ampliar.

Entendemos que existe um rol de atividades que são priorizadas dentro da instituição e que seguem protocolos de financiamento já estabelecidos. O que veremos no capítulo 5 é que as negociações para o auxílio financeiro em prol do

${ }^{25}$ SECIS - Secretaria de Ciência e Tecnologia para Inclusão Social fazia parte do antigo Ministério da Ciência Tecnologia e Inovação, a sua extinção ocorreu juntamente com o DEPDI (Departamento de Popularização e Difusão da Ciência e Tecnologia) com o Decreto 8877 , de 18/10/2016, cujos papéis eram fundamentais para a manutenção de políticas públicas na área da Divulgação da C\&T. 
Túnel da Ciência envolve tensões que permeiam a visão de Divulgação Científica das insituições envolvidas e a necessidade de soluções burocráticas que viabilizem a transferência de recursos do MCTIC para o Max Planck.

\subsection{A VISITAÇÃO DO PÚBLICO ESPONTÂNEO - DE QUAL OU QUAIS ATIVIDADE(S) ESTAMOS FALANDO?}

A análise preliminar que apresentamos aqui busca identificar a relação entre os visitantes espontâneos e o Túnel da Ciência. Essa análise tenta compreender uma possível atividade desse grupo e sua relação com os demais sistemas de atividades.

Para essa análise, utilizamos tanto as transcrições das entrevistas pré e pósvisita quanto as das filmagens. Com isso buscamos possíveis atividades(s) desenvolvida(s) por esses visitantes.

Tomamos como exemplo a Família 2, composta pela mãe Tina (graduação em Direito) e pela filha Antônia, residente na cidade de São Paulo, frequentadora de museus para conhecimento de outras culturas e que permaneceu na exposição durante 45 minutos.

Ao questionar a mãe 2 sobre os motivos de visitarem a exposição, foi indicada a aprendizagem como o principal ponto. Além disso, ao definir os objetivos da exposição, a entrevistada afirma que:

Trechos 37 - 38: Visita da Família 2

37. PESQUISADOR: $E$ o que te motivou vir até a exposição?

38. TINA: Eu quero aprender coisas relacionadas às Ciências, além de ser importante para minha filha também.

Nesse sentido, podemos entender que, para essa mãe, o objeto com que interagem seriam os conhecimentos científicos expostos. Esse fato fica evidente quando, ao se analisar diversos pontos da filmagem, percebemos que a mãe tenta em vários momentos chamar a filha para que essa preste atenção no que acredita que seja importante.

Trecho 120 - 121: Visita da Família 2

TINA: Vem oh, dá uma olhada com calma. Olha que legal filha, já sabe ler né? Então se joga.

TINA: Olha mistura de raças, acho que tá falando isso. Isso não é foto, não é pra você mexer (Aponta para um painel sobre raças e genética. Filha tenta mexer no painel achando que é touchscreen). 
Este direcionamento dado pelos pais à atividade de visitação também é perceptível no caso das outras famílias. Em geral, os pais buscam indicar o que os filhos deveriam ver, além de elaborarem explicações sobre como manipular os objetos da exposição ou sobre as dúvidas que os filhos trazem.

Trecho 57 - 60: Visita da Família 3 (Visitantes assistem o vídeo em silêncio)

57. ISABEL: Aí o tamanho da envergadura. Tudo isso aí ele está falando de gravidade.

58 ISABEL: Gravidade é o quanto que puxa a gente para o centro da Terra. Você não viu que quando as pessoas estão no espaço...

59 RAFAELA: Ficam flutuando.

60 ISABEL: A gente não está preso ao chão? Isso é gravidade.

Analisando a situações de visitação, fica claro em alguns casos as diferentes atividades no caso dos pais e dos filhos, aqueles direcionados por motivos relacionados à aprendizagem de conteúdos científicos e esees buscando compreender e signficar o mundo, conforme explicitado no trecho a seguir:

Trecho 132-133: Visita da família 2

132. ANTÔNIA: Mamãe vem cá.

133. TINA: Filha vem aqui, isso é importante de você aprender. Tá vendo ela está apertando ali e está acendendo aqui para saber qual região é responsável. Essa feira é necessária mais vezes. Você viu filha? Presta atenção você é muito ansiosa, isso não é brinquedo, você tem que aprender o que está aqui.

Além dessa tensão em relação às diferentes configurações da atividade de visitação, essas situações podem se tornar conflituosas, quando os visitantes buscam auxílio dos monitores, mas não conseguem porque estes estão atuando junto ao público escolar como veremos no capítulo 5 .

A situação exposta implica alguns questionamentos a serem retomados posteriormente: como as grandes exposições itinerantes, internacionais e científicas podem trabalhar para atender a heterogeneidade dos seus públicos? Como elas podem trabalhar de modo que se adequem a países com hábitos diferentes de aproximação com as ciências?

\subsection{A ATIVIDADE DE MONITORIA: A TRANSFORMAÇÃO DO OBJETO AO LONGO DO TEMPO}

Considerando os pressupostos da Teoria Histórico-Cultural da Atividade, os 
monitores estão inseridos, em maior ou menor grau, em uma atividade de interpretação da exposição e promoção do diálogo entre o público e as questões expostas, gerando novas possibilidades de significação.

A atividade de monitoria está permeada de contradições internas, conflitos e tensões que regulam e conferem movimento a ela, permitindo 0 seu desenvolvimento, como por exemplo, a forma de atuação dos monitores na exposição que sofre influência dos demais sistemas de atividades. Nessa relação, as regras de trabalho desses profissionais precisou ser negociada ao longo do tempo a fim de satisfazer suas necessidades.

Uma das possibilidades de representação da atividade principal da monitora entrevistada, dentro de um sistema de atividade maior, está apresentada na Figura 22:

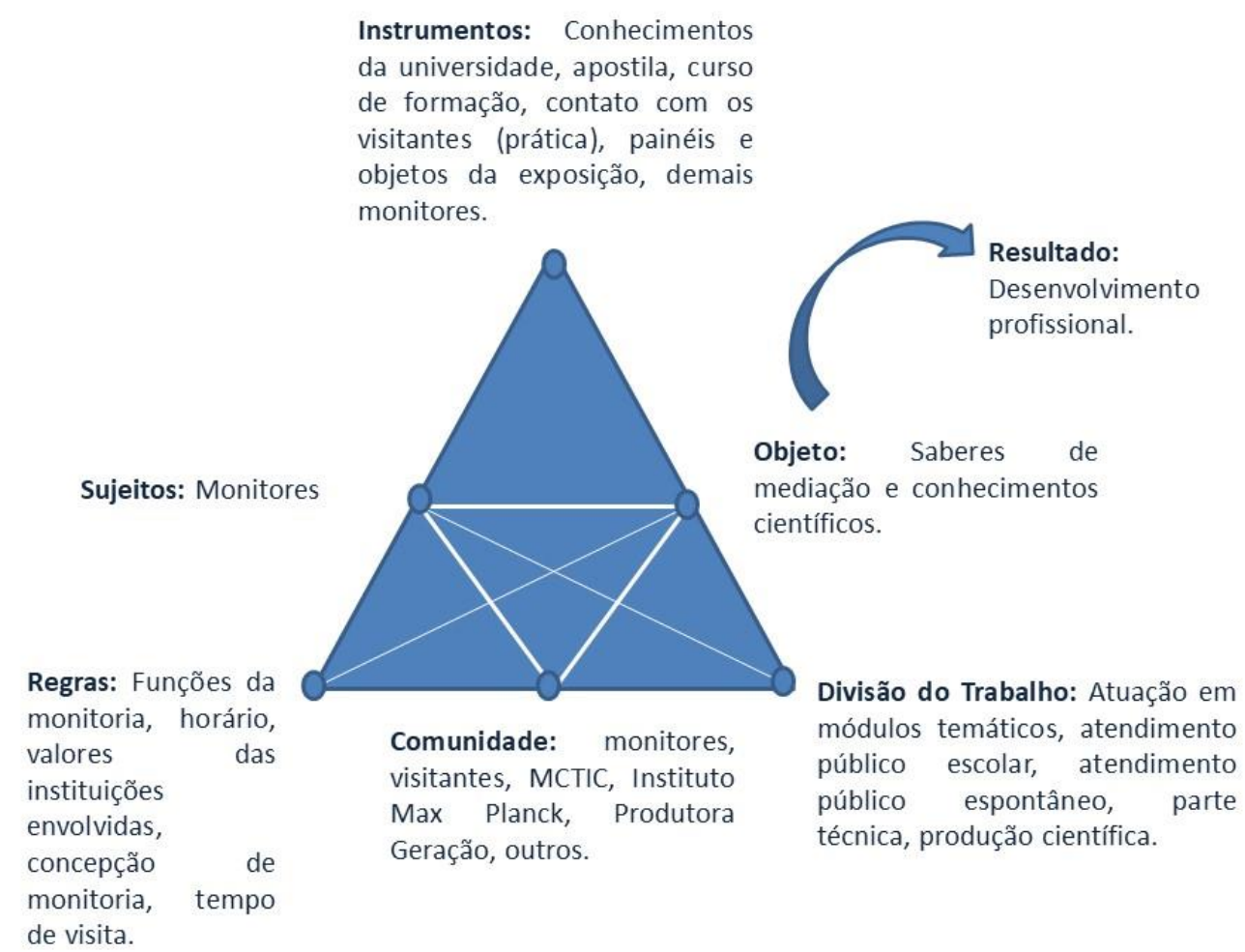

Figura 22 - Modelo de sistema de atividade do monitor. Fonte: autoria própria.

Nessa representação de um possível modelo de atividade, temos o monitor como sujeito que faz parte de uma comunidade composta por outros indivíduos que estão envolvidos no processo de significação da exposição. A diversidade de sujeitos resulta em diferentes tarefas atribuídas a cada um e essa divisão de trabalho é representada no vértice direito do triângulo. Além disso, existem regras e convenções que irão nortear a atividade desenvolvida pelo monitor. Essa base do 
triângulo caracteriza a regulação do ambiente social e coletivo em que a atividade humana ocorre. A atividade é então direcionada a um objeto que, ao ser transformado, culmina em um resultado. Para esse fim, são utilizados alguns instrumentos, sejam materiais e/ou simbólicos.

No modelo em questão, o monitor vislumbra como resultado, o seu desenvolvimento profissional e, dessa forma, direciona a sua atividade na exposição para os saberes de monitoria e os saberes científicos envolvidos com os assuntos a serem abordados durante as visitas. Essa estrutura reflete as suas necessidades e motivos que envolvem aprimorar a sua prática de monitoria.

Ressaltamos, porém, que é necessário um olhar dinâmico e histórico para a atividade. Dessa forma entendemos, a partir da entrevista, que os monitores operam transformações em suas motivações e, consequentemente, em sua atividade. Inicialmente, os monitores tinham como necessidade fazer contatos profissionais com pesquisadores do Instituto Max Planck, referências em sua linha de pesquisa. Isso se relacionava com o motivo, que era se tornar um pesquisador, o que configura outro tipo atividade. Nesse sentido, a atividade de monitoria poderia, inicialmente, se configurar apenas como uma ação ou instrumento constituinte da atividade de tornar-se pesquisador (Figura 23).

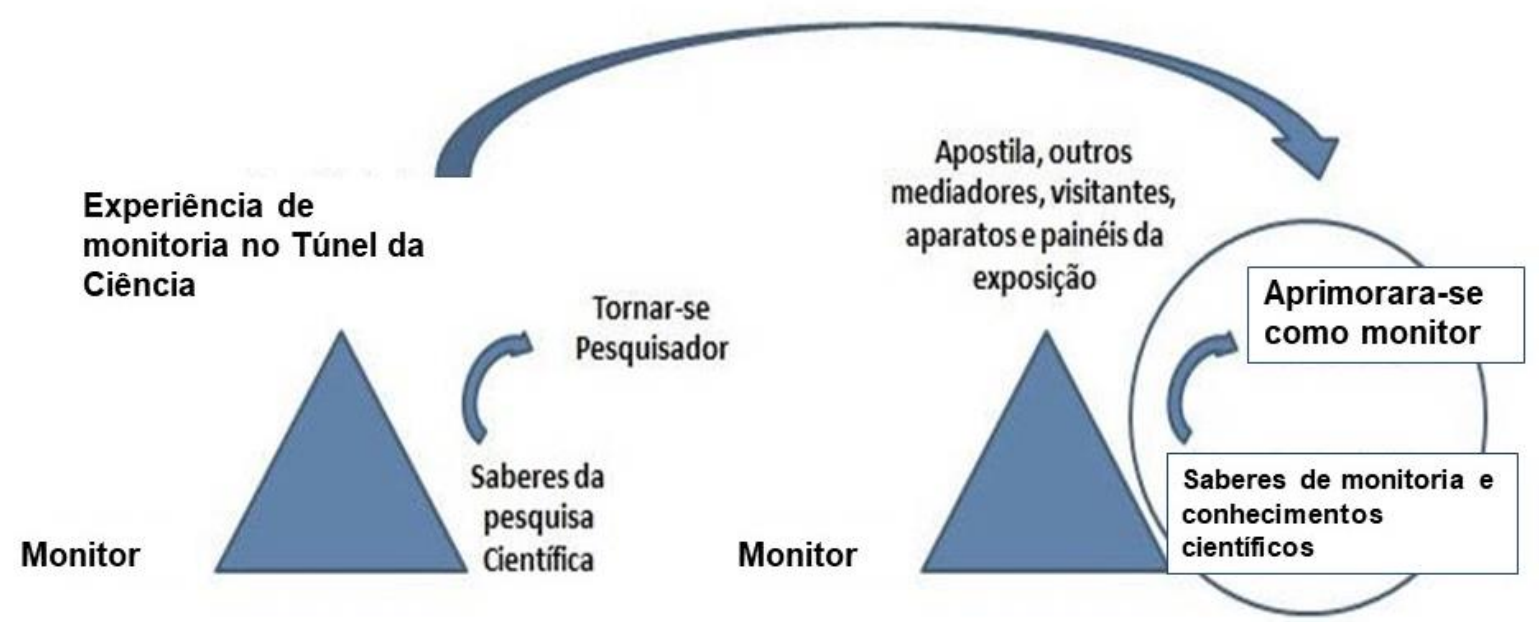

Figura 23 - O movimento na atividade do monitor. Fonte: autoria própria.

Entendemos que, ao longo de sua prática na exposição, há uma mudança no objeto da atividade principal do sujeito. Dessa forma, não estamos afirmando que uma atividade é encerrada e outra se inicia, mas que, no momento da entrevista, a atividade principal dos monitores está, nesse olhar dinâmico, se direcionando para a atividade de monitoria. Dessa forma, os motivos da atividade são direcionados ao 
objeto da mesma, sendo entendidos como motivos eficazes.

Exposto esse cenário, é necessário questionar quais características permitiram que os monitores participantes deste estudo entrassem em atividade de monitoria. Para isso, voltamos o nosso olhar para as contradições e tensões envolvidas nesse processo.

Segundo Engeström (1999), as contradições que surgem nos sistemas de atividades não equivalem a problemas ou conflitos, já que são tensões acumuladas historicamente e podem provocar a mudança de atividade. Sendo assim, para que haja a mudança desse sistema, deve ocorrer uma reflexão sobre a estrutura anterior dele e uma interiorização de modelos e ferramentas avançadas para resolver essas contradições internas. "Na medida em que o processo de internalização estimula a autorreflexão, cresce também a busca de soluções para essas contradições e, consequentemente, o processo de exteriorização torna-se cada vez mais importante" (BIZERRA, 2009, p.71). Depois que um novo modelo de atividade é implantado, como sugerido por Engeström (1999), o processo de reflexão e interiorização de novos significados reinicia, promovendo, depois de certo tempo, uma nova estrutura de atividade. Esse movimento de interiorização e exteriorização, o autor denominou de "ciclos expansivos de atividade".

Podemos perceber que a intensa atividade dos monitores na exposição faz com que, apesar da pouca experiência nessa área, esses profissionais busquem estratégias para lidar com as situações que vão surgindo na prática. Assim, aos poucos, eles foram questionando algumas estruturas como a forma de atuação sugerida pelo Max Planck, a falta de exemplos de pesquisas científicas brasileiras na exposição, a não possibilidade de atuar junto ao público espontâneo, entre outras, promovendo assim, engajamento e atribuição de motivos eficazes a atividade de monitoria.

\subsection{ATIVIDADE VIABILIZAÇÃO DO TÚNEL DA CIÊNCIA NO BRASIL: ARTICULAÇÃO ENTRE OBJETIVOS CONFLITANTES}

Conforme apresentamos na descrição dos participantes da pesquisa, a Produtora Geração é uma empresa especializada na elaboração e viabilização de eventos culturais, ambientais e educacionais, atuando há mais de 30 anos no 
mercado brasileiro. Hoje, com sede e filiais em Belo Horizonte, São Paulo e Rio de Janeiro, o representante da Produtora Geração relatou que a empresa tem uma forte experiência em atendimento de grupos escolares e de captação de recursos junto a empresas privadas e o setor público.

O contato com o Instituto Max Planck aconteceu por meio do Cônsul Honorário da Alemanha em Belo Horizonte, que conhecia o trabalho da empresa e relatou ao diretor geral da produtora o descontentamento do governo alemão em não ter conseguido trazer o Túnel da Ciência ao Brasil. Nesse contexto, acontece uma aproximação entre a Produtora Geração e o Max Planck, e a partir das negociações e alinhamento de ideias foi assinado um contrato entre as instituições.

Como representante oficial do Túnel da Ciência no Brasil, a tarefa da Produtora Geração era articular diversos grupos para que a exposição pudesse ser realizada. Além disso, a empresa era responsável por buscar apoio financeiro junto a instituições públicas e privadas. Como relatado no capítulo anterior, a Produtora Geração é a única instituição que se faz presente desde o início das negociações até a finalização da exposição, tendo, assim, um papel importante como articuladora.

Em busca de caracterizar a atividade da Produtora Geração, elaboramos a Figura 24, que evidencia seus elementos constituintes. A partir dessa sistematização, será possível discutir como essa atividade e seus elementos podem estar relacionados com os sistemas de atividades dos outros sujeitos, além de refletir sobre as tensões e contradições presentes. 


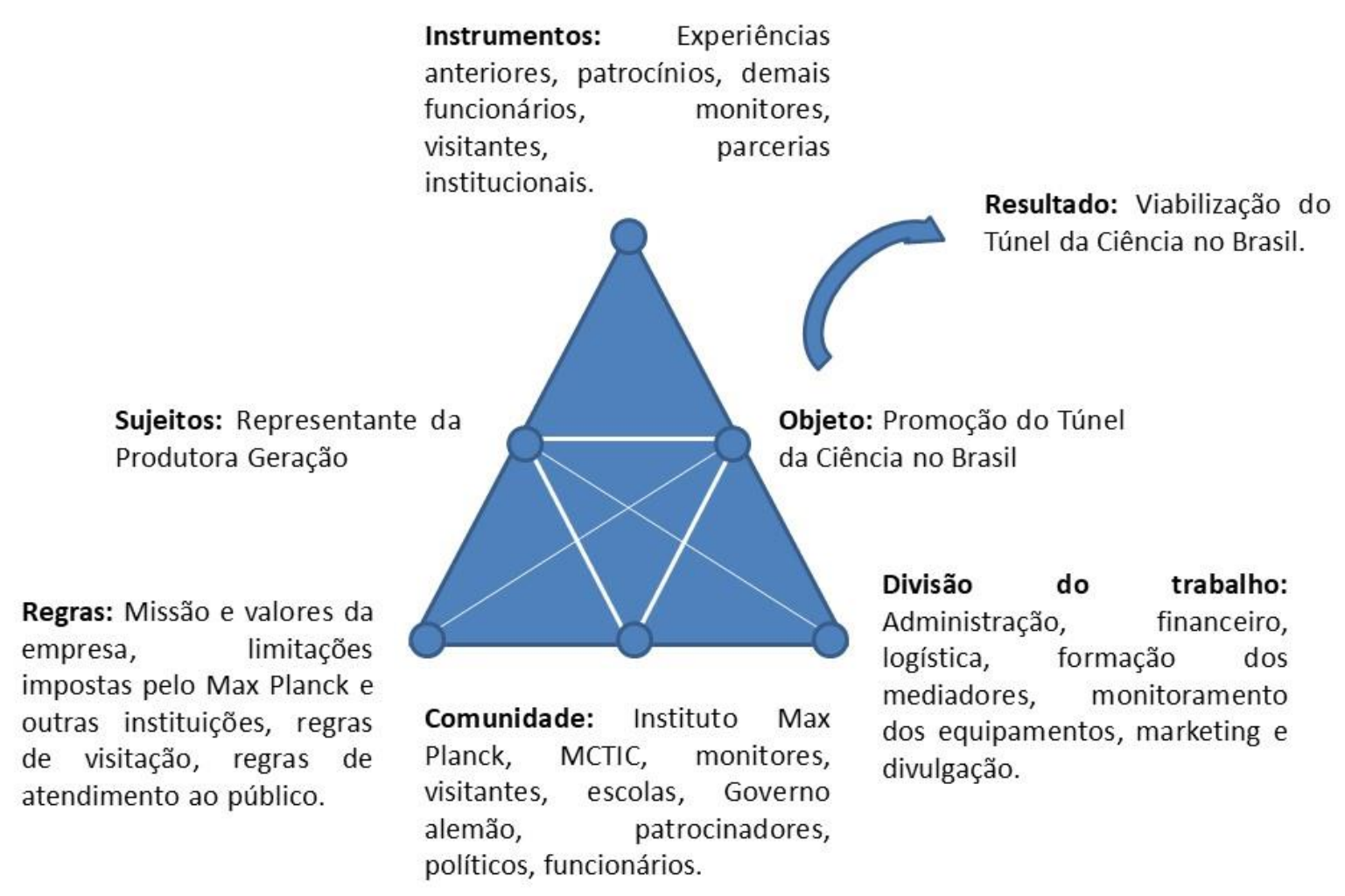

Figura 24: Caracterização da atividade da Produtora Geração. Fonte: autoria própria.

Para identificar o objeto em transformação dessa atividade, foi necessário buscar, no discurso do representante da instituição, falas que representassem suas motivações e necessidades, bem como seu entendimento sobre o seu próprio papel e o trabalho que estava sendo realizado. Abaixo, apresentamos um trecho que serviu de base para nossa análise:

Trecho 10 - MARCELO: Então tem esses dois formatos, projetos sob encomenda e projetos que nós desenvolvemos e vamos em busca de patrocínio. O Túnel da Ciência é um formato desse, ele acaba sendo dois, ele é uma demanda do governo da Alemanha e aí a gente desenvolveu o Túnel da Ciência, a gente fez algumas adaptações no formato que eles fazem, hoje poucas, mas a gente faria mais e também com patrocinadores.

Entendemos que, para a produtora, o objeto da sua atividade é a promoção do Túnel da Ciência no Brasil. Esse termo, nesta investigação, significa tanto realizar adaptações necessárias, como citado no excerto acima, como articular parcerias com diversos outros grupos (governos brasileiro e alemão, monitores, patrocinadores, entre outros). O fato da empresa estar em contato direto com 
diferentes atores sociais cria em sua atividade diversas tensões a serem administradas a fim de que o resultado de sua atividade seja atingido. 


\section{AS CONTRADIÇÕES}

Ao analisar os sistemas de atividades dos participantes podemos identificar cinco principais núcleos temáticos que indicam a presença de tensões. São eles: ideias e valores, motivos, a exposição, a gestão e a mediação. Dentro desses núcleos, conseguimos mapear os conteúdos das contradições e os categorizar (QUADRO 7) e, assim, desenvolvemos o quadro abaixo que será abordado em mais detalhes nas seções a seguir:

QUADRO 7. Quadro de categorização dos conteúdos das contradições

\begin{tabular}{|c|c|c|}
\hline Núcleos de tensões & Descrição & $\begin{array}{l}\text { Categorização } \\
\text { dos conteúdos } \\
\text { contradições }\end{array}$ \\
\hline \multirow[t]{2}{*}{ Ideias e valores } & \multirow{2}{*}{$\begin{array}{l}\text { Nesse grupo identificamos ideias e } \\
\text { valores expressos a partir do } \\
\text { discurso dos participantes, que } \\
\text { envolvem concepções geradoras de } \\
\text { contradições dentro dos sistemas de } \\
\text { atividades e entre eles. }\end{array}$} & $\begin{array}{l}\text { Ciência local x } \\
\text { Ciência global }\end{array}$ \\
\hline & & $\begin{array}{l}\text { Financiamento } \\
\text { público } x \\
\text { Privado }\end{array}$ \\
\hline \multirow[t]{2}{*}{ Motivos } & \multirow[t]{2}{*}{$\begin{array}{l}\text { Os motivos envolvidos em diferentes } \\
\text { sistemas de atividades que ao } \\
\text { interagirem geram contradições. }\end{array}$} & $\begin{array}{l}\text { Aprender } \\
\text { conteúdos } \\
\text { científicos } x \\
\text { explorar os } \\
\text { aparatos } \\
\text { interativos }\end{array}$ \\
\hline & & $\begin{array}{l}\text { Divulgação } \\
\text { institucional x } \\
\text { Divulgação das } \\
\text { ciências }\end{array}$ \\
\hline
\end{tabular}




\begin{tabular}{|c|c|c|}
\hline \multirow[t]{2}{*}{ A exposição } & \multirow{2}{*}{$\begin{array}{l}\text { A forma como a exposição é } \\
\text { concebida, apresentada e significada } \\
\text { pelos participantes da pesquisa gera } \\
\text { contradições que exigem a busca de } \\
\text { soluções práticas, recaindo, muitas } \\
\text { vezes, no trabalho dos monitores. }\end{array}$} & $\begin{array}{l}\text { Modelos } \\
\text { dialógicos x } \\
\text { Valores } \\
\text { universais }\end{array}$ \\
\hline & & $\begin{array}{l}\text { Interatividade: } \\
\text { discurso } \\
\text { midiático } \mathrm{x} \\
\text { discurso } \\
\text { expositivo }\end{array}$ \\
\hline \multirow[t]{2}{*}{ Gestão } & \multirow{2}{*}{$\begin{array}{l}\text { O processo de internacionalização } \\
\text { de uma exposição científica envolve } \\
\text { uma série de articulações entre } \\
\text { diferentes instituições que possuem } \\
\text { estruturas e valores definidos. As } \\
\text { contradições aí presentes são } \\
\text { latentes quando há a interação entre } \\
\text { os sistemas de atividades. }\end{array}$} & $\begin{array}{l}\text { Negociações: } \\
\text { entre o } \\
\text { planejado x } \\
\text { Efetivado }\end{array}$ \\
\hline & & $\begin{array}{l}\text { Formalização } \\
\text { institucional da } \\
\text { concepção de } \\
\text { DC x } \\
\text { Instabilidade } \\
\text { política }\end{array}$ \\
\hline \multirow[t]{2}{*}{ Monitoria } & \multirow{2}{*}{$\begin{array}{l}\text { A regulação da atividade de } \\
\text { monitoria que passa pela influência } \\
\text { de outros participantes gera a } \\
\text { necessidade de lidar com } \\
\text { contradições. }\end{array}$} & $\begin{array}{l}\text { Teoria x Prática } \\
\text { de monitoria }\end{array}$ \\
\hline & & $\begin{array}{l}\text { Monitoria junto } \\
\text { ao público } \\
\text { escolar x } \\
\text { Monitoria junto } \\
\text { ao público } \\
\text { espontâneo }\end{array}$ \\
\hline
\end{tabular}

Como apontado por Engeström (1999), as tensões ocorrem por diversos motivos, dentre eles podemos citar: a inserção de novos procedimentos (propostos 
ou implementados formalmente), a criação de regras para as atividades e a supressão de um instrumento. As tensões sinalizam também a presença de contradições e, assim, haverá a possibilidade de falta de aceitação e resistência. Se isso acontecer, emerge um conflito que pode paralisar o desenvolvimento de transformações expansivas. Por outro lado, as superações das contradições podem ser fonte de potência e inovação para a atividade.

Olhar para os conteúdos das contradições possibilita mapear os cenários no qual as relações sociais foram se estabelecendo, permitindo que possamos discutir as questões que estão relacionadas com essas temáticas.

\subsection{CONTRADIÇÕES DE IDEIAS E VALORES}

\subsubsection{Ciência local x Ciência global}

Qual a identidade da Ciência que é apresentada no discurso expositivo do Túnel da Ciência? Tal questionamento se torna ainda mais necessário quando o nosso objeto de análise é uma exposição de itinerância internacional. Sabemos que a exposição foi baseada nos resultados de pesquisas desenvolvidas pelo Instituto Max Planck da Alemanha, porém, como o público interpreta essa relação entre o conteúdo da exposição e sua origem?

Ao entrevistarmos as famílias após visitarem a exposição, foi unânime a afirmação de que era possível entender que o que estava sendo apresentado era resultante do trabalho do Instituto Max Planck, ou seja, era possível estabelecer uma identidade institucional ao discurso expositivo. Mais do que isso, foram identificadas, em especial, comparações com a Ciência que é desenvolvida no Brasil, como percebido no trecho da gravação da visita da família 2, ao observar a simulação de uma máquina de raio- $x$, intitulada espelho mágico:

89. TINA: Isso já está sendo utilizado nas clínicas do SUS?

90. MONITORA: Não, a gente está usando mais como um modelo didático.

91. TINA: SUS não tem nem nada, né?

92. MONITORA: A ideia é mais ser uma didática, uma demonstração do que uma imagem real.

93. TINA: É, eu entendi.

94. OUTRO VISITANTE: Ah, mas no futuro...

95. TINA: É, mas isso aí já tem em outros países né gente, aqui no Brasil precisa melhorar um pouquinho, mas eu acho tudo.

Durante a entrevista pós-visita, Tina reafirma que a exposição deixa claro como, em sua opinião, a Ciência alemã está muito mais avançada em relação ao 
que temos no nosso país:

179. TINA: Claro que eles estão muito mais capacitados e preparados que nós, né?

180. PESQUISADOR: Isso fica evidente na exposição?

181. TINA: Muito, a primeira coisa é isso aí.

Tal situação vai ao encontro do que apresentamos na introdução desta investigação em relação à ligação entre os brasileiros e as Ciências: as pesquisas de percepção pública das Ciências apontam que não há conhecimento dos cidadãos em relação às instituições de pesquisa e seus resultados. Da mesma forma, no caso exposto, esses elementos não compõem os instrumentos da atividade. O que se apreende desse contexto é que há uma tensão latente durante a visitação no tocante à comparação entre o que os visitantes conhecem e é divulgado sobre a Ciência brasileira e os avanços científicos do Instituto alemão que são apresentados na exposição. Tal tensão atinge o seu pico fazendo com que os monitores alterarem sua atividade de monitoria a fim de tentar superar essa contradição. A saída encontrada foi inserir alguns elementos nos seus discursos durante o diálogo com os visitantes:

83 - PESQUISADOR: Então, a partir da sua experiência na exposição, você considera que os visitantes relacionam ou comparam as pesquisas brasileiras com as pesquisas alemãs?

84 - ISABELA: Hum...pelo menos lá no [módulo] cérebro a gente faz essa comparação.

85 - PESQUISADOR: Vocês, monitores, fazem?

86 - ISABELA: Sim, porque a gente fala do chute inicial da copa do mundo, a gente fala da ressonância magnética dos hospitais daqui. $A$ gente faz esse paralelo assim.

87 - PESQUISADOR: Qual a importância de fazer isso, você acha?

88 - ISABELA: Ah...eh, assim se a gente não faz isso, dá a impressão de que o país é uma droga, está vendo como os alemães são muito melhores que a gente e a gente é muito ruim. Então eu faço questão de mostrar isso de que a gente não é ruim, a gente é bom, olha os alunos aqui como são bons, tudo mais, a gente não está tão atrás da Alemanha, tem muita coisa boa aqui também, se a gente não faz isso dá a sensação de que a gente é muito pequeno perto de tudo isso.

89 - PESQUISADOR: Pela forma que está estruturada a exposição 
né?

90 - ISABELA: É....porque está tudo ali, todas as pesquisas são da Alemanha.

O que fica evidente é que há um questionamento da Isabela sobre os efeitos da apresentação da exposição sem a associação a um discurso que também enfatize a identidade e características das Ciências desenvolvidas no Brasil. A monitora, em questão, assume uma posição crítica à forma como foi concebida a exposição, caracterizando um conflito. Essa contradição mobiliza a profissional a buscar em sua prática junto ao público, saberes de mediação e de conhecimentos científicos que a fizessem superar essa contradição. Não podemos mensurar, nessa pesquisa, os efeitos dessa estratégia em relação à experiência do público, porém, o mais importante aqui é o início de um microciclo de aprendizagem expansiva em que Isabela questiona a situação vigente e busca uma forma de superação, testando as suas alternativas em sua prática profissional.

Outra questão diz respeito ao processo de internacionalização. Nesse movimento surgem tensões e, dentre elas, destacamos aquelas relativas à necessidade de adaptações a questões locais, negociações entre governos e monitores.

\footnotetext{
Trecho 82 - PESQUISADOR: Ontem você disse isso, eu acho que foi a China, eles fizeram uma outra exposição do Túnel da Ciência. (Tradução nossa).

Trecho 83 - RAFAEL: Uma pré-condição para eles apresentarem o Túnel da Ciência era que eles trariam alguma coisa adicional para o Túnel (...). Então eles tinham a sua própria exposição. $E$ isso seria um local no Túnel da Ciência apresentando resultados chineses da nanotecnologia e outros resultados (Tradução nossa).
}

Vemos que a contradição da Ciência Local x Global permeia a história da atividade de internacionalização do Túnel da Ciência, de modo que, na China, a forma encontrada para superar tal situação foi a inclusão de uma exposição anexa, em que fossem acrescidos elementos da ciência chinesa, modificando, assim, a ideia inicial e pré-concebida pelo Instituto Max Planck.

Em relação a esse processo de mobilidade do Túnel da Ciência, outro ponto afirmado pelo representante do Max Planck é que há apenas uma tradução dos textos presentes nos painéis. Desse modo, pode-se compreender que não é vista a necessidade de inclusão de conteúdos relativos a questões locais no discurso 
expositivo. Na entrevista, identificamos que a raiz de tal motivação reside nos valores que permeiam a atividade de concepção da exposição, constituindo assim uma contradição no campo axiológico, em que há relações com os valores presentes na constituição da atividade, como podemos perceber no trecho a seguir:

Trecho 81. RAFAEL: (...) os próprios resultados científicos não têm nenhuma diferença cultural. Mas o método de transportar, de transformar, de interpretá-los em uma determinada cultura, que é algo que é cultural. Então, existem diferenças nos diferentes países, como as atitudes para fazer a ciência, aceitando que a ciência é diferente, vimos isso na França, por exemplo. O medo de novos desenvolvimentos é quase inexistente em comparação com a Alemanha, onde muitas pessoas pensam em alguma coisa que possam utilizar. Eles obtiveram sucesso com as leis proibindo experiências genéticas em soja na Alemanha, porque esse era o medo, de que as pessoas teriam algum dano, que só seria descoberto depois de anos e anos e anos. Então, há uma certa atitude em diferentes países para obter os resultados. Mas os resultados em si não mudam, porque eles estão de acordo com as leis naturais, eles não mudariam por causa da cultura. (Tradução nossa).

Como vemos, há uma perspectiva universal da Ciência que faz parte do sistema de atividade de concepção do Túnel da Ciência, conforme apresentado. Rafael reforça tal ideia ao afirmar que os resultados aos quais a Ciência chega são os mesmos independentemente da cultura, sendo que o que se transforma é a forma de interpretação. Esse posicionamento pode conduzir à ideia de Ciência Universal: embora "as atitudes para fazer ciência" sejam próprias de cada país, seus resultados são, " de acordo com as leis naturais", universais. Isso implica que, para ele, apresentar os resultados das pesquisas alemãs em diferentes países não se caracteriza como uma tensão propriamente dita, pois o que está sendo apresentado são apenas os resultados, cabendo ao visitante significá-los. As Ciências, universais, estariam, portanto, descoladas de seu contexto, social e politicamente, como uma atividade hermética que seria apropriada localmente. Como veremos no núcleo de tensões relativas à monitoria, tal cenário acaba não se concretizando, o que implica na necessidade de operação de mudanças na atividade do monitor.

\subsubsection{Financiamento público x privado}

Sabemos que a vinda de uma exposição de grande proporção como o Túnel da Ciência envolve a necessidade de um forte apoio financeiro. Ao mesmo tempo, é latente no nosso país que há uma grande dependência dos recursos públicos para o 
financiamento de atividades culturais e, assim, em um cenário de forte crise política e econômica, é previsível a emersão da contradição entre o financiamento público $\mathrm{x}$ privado de tais atividades. No caso do Túnel da Ciência, percebemos que o modelo de financiamento praticado, de certa forma, foi incorporado como um instrumento da atividade do MCTIC, indicando uma mudança no sistema de atividade que envolve a instituição:

27. TIAGO: É um modelo que tem muito mérito. A iniciativa privada tem que ser uma parceira, sim. Então, por exemplo, o fato de boa parte dos recursos serem de empresas privadas e viabilizados por outra empresa privada que ganhou evidentemente dinheiro, não há crime nisso nenhum, é um projeto que a gente tem que ver se queremos se apropriar desse modelo e tentar expandi-lo. Então, isso foi em 2014. Em 2015, conseguimos uma parceria com Instituto Tim para o edital da Luz. Então a sustentabilidade pode estar nesse caminho, as instituições privadas e trazê-las... e isso é possível, não foi uma coincidência isso, quer dizer que existe um ambiente onde isso pode se desenvolver de maneira sustentável.

As cristalizações da experiência humana, assim como as significações sociais, têm como características a expressão de sínteses históricas dos produtos culturais, sejam palavras, objetos, conceitos ou o conhecimento de forma geral. Elas não podem ser vistas como eternas, pelo contrário, a sua mobilidade é ponto fundamental: são produtos da história humana e, como tal, transformam-se com as mudanças da língua, dos valores, da política (LEONTIEV, 1983).

No Brasil, assim como em outros países considerados em desenvolvimento, a relação entre o público e o privado, na área cultural, é carregada de embates. Cada vez mais, organizações privadas aumentam seus domínios nos entes públicos, assessorando, redefinindo e estabelecendo novas diretrizes para políticas públicas. Segundo Allan Kenji (2018, p. 5), "são forças sociais concentradas com tamanha inserção em setores como a economia brasileira que têm a capacidade de impor as políticas no âmbito do Estado. É o que a gente chama de se fazer Estado".

Por outro lado, os recursos oriundos de empresas privadas, via leis de incentivo fiscal, vêm auxiliando o financiamento das ações culturais no Brasil e, mais particularmente, a sobrevivência e manutenção de diversas instituições culturais brasileiras. A grande questão é a forma como tais empresas podem interferir ou não nessas práticas culturais. Conforme destacado por Veloso e Andrade (2016), há empresas privadas operando como financiadoras e gestoras de alguns museus. Nesses casos, a iniciativa privada é responsável pela exclusão e seleção de 
conteúdos da exposição, dando ênfase a interesses particulares da empresa e deixando de lado os interesses da sociedade.

A Produtora Geração foi a grande responsável pela articulação com empresas privadas com o objetivo de levantar fundos para viabilização da vinda do Túnel da Ciência ao Brasil. Marcelo cita que os conhecimentos desses processos já faziam parte da atividade da empresa:

Trecho 20. MARCELO: Em 1990, acontece nosso primeiro grande projeto com patrocínio de uma grande empresa de cosméticos que nos possibilitou um ganho conceitual interessante porque a Fundação Boticário já era uma organização com uma liderança grande no movimento ambiental brasileiro. E tinha a parte comercial, que era o Boticário querendo vender e a gente fez um projeto grande, enfim... Então os nossos projetos foram se desenvolvendo e foi conquistando outros patrocinadores.

$[\ldots]$

Trecho 48. MARCELO: Então, eu acho que com a exposição a gente contribuiu sim para demonstrar para os agentes econômicos privados que é uma boa estratégia de comunicação investir em divulgação científica, agregar a marca das empresas a essa questão tecnológica, acho que isso está claro para as empresas que ficaram satisfeitas.

Fica evidente que, nessa relação entre o financiamento de atividades culturais e as empresas privadas, há uma multiplicidade de interesses, entre os quais é preciso lidar com a visão mercadológica da cultura. Uma das tarefas, presente no sistema de atividade da produtora, era permitir a visibilidade das marcas patrocinadoras de modo que elas pudessem ver o retorno de seus investimentos. Tal situação gera uma tensão pelo fato de que as ações que compõem o sistema de atividade da produtora devem sair conforme previsto, como enfatiza Marcelo, ao falar sobre a inauguração da exposição que contou com a presença de políticos e empresários:

Trecho 55. MARCELO: No lançamento é o jogo, o final do campeonato, você não tem outro momento, você não tem como recuperar um momento em que você coloca todas as pessoas, todos envolvidos em um teatro e que tem que dar certo senão atrapalha inclusive as questões políticas que viabilizam o evento. Então esse é um ponto crítico, que tem que existir porque as pessoas precisam se encontrar, precisam conversar que é um risco, mas é fundamental, é onde os caras querem aparecer mais que os outros, onde pode dar algum problema de estrutura e é ruim. Então é uma atividade absolutamente importante do ponto de vista político e tem que dar certo, não tem como dar errado, então as pessoas precisam ser bem acolhidas, precisam estar satisfeitas, "pô meu dinheiro está sendo bem gerido", e ver isso acontecer. Então são muitas pessoas, muito poder, de diferentes interesses, muita repercussão. 
A partir da análise dessa contradição, também podemos ver a operação de mudanças na estrutura da atividade do MCTIC, que introduz aspectos do financiamento privado como instrumentos de sua atividade, trazendo soluções internas para lidar com a falta de recursos financeiros. No caso da produtora, essa tensão em relação ao retorno que deveria ser dado aos empresários permeou toda sua atividade de viabilização da exposição no Brasil. Como sabemos, esses sistemas de atividades possuem dinamicidade e, assim, estão em constantes transformações, sendo a superação das contradições internas e externas fator essencial para o estabelecimento de novas práticas. Nesse processo, percebe-se como a integração destes sistemas é condição para que as constantes mudanças possam ser compreendidas pelas comunidades envolvidas. Porém, ressalta-se que o desenvolvimento e incorporação de um artefato é um processo contínuo de negociação que envolve os valores de todos os interessados em busca de resultados satisfatórios e, portanto, não ocorre com ausência de embates.

\subsection{MOTIVOS}

\subsubsection{Divulgação institucional x divulgação das ciências}

Uma questão que podemos levantar em relação à circulação de exposições científicas entre diferentes países refere-se às intenções educacionais e comunicacionais de tais práticas. Assim, é necessário evidenciar a contradição entre divulgar as ciências almejando que os visitantes tenham contato com a cultura científica e, em contraponto, lidar com a necessidade de divulgação institucional das organizações envolvidas com a concepção da exposição.

No caso do Túnel da Ciência, podemos perceber que essa é uma contradição que percorre a história da atividade de internacionalização da exposição. Por exemplo, tivemos acesso à forma como a mostra foi recebida na China, quando houve uma negociação para adequar o Túnel da Ciência às necessidades do país:

Trecho 86. RAFAEL: Sim, os chineses ... o motivo pelo qual nós fomos a Pequim em maio foi o $40^{\circ}$ aniversário da cooperação entre Academia Chinesa de Ciências e Sociedade Max Planck. Para esta celebração, apresentamos o Túnel da Ciência como uma espécie de um presente. Eu tenho que pagar isso do meu orçamento, e só recuperá-lo depois de um ano. [...]. Uma pré-condição para eles apresentarem o Túnel Ciência era que eles trariam alguma coisa adicional para o Túnel [...]. Então eles tinham a sua própria exposição. $E$ isso seria um local no Túnel da Ciência 


\begin{abstract}
apresentando resultados chineses da nanotecnologia e outros resultados.

Trecho 87. PESQUISADOR: Mas será que eles alcançaram o mesmo design da exposição?

Trecho 88. RAFAEL: Eles queriam fazê-lo muito parecido, eles realmente queriam. $O$ mais frequente é dizer que a tecnologia chinesa é apenas modelar, imitando o que tem a... Essa é a diferença de algo original e alguma outra coisa.... Então, eu tenho que ter certeza de que não será apresentado como o Túnel da Ciência. Porque ainda queremos ter o nosso único ponto de venda.
\end{abstract}

Vemos que há uma modificação introduzida na atividade de concepção do Túnel da Ciência, que, no caso, incorpora um anexo expositivo relativo aos resultados científicos de grupos de pesquisas chineses. Porém, percebemos que essa aceitação não é automática, são longos embates, que apesar de parecerem superados muitas vezes não o são. Vemos que apesar de aceitar a introdução desse anexo, Tiago ressalta a preocupação em manter a imagem institucional como única, se diferenciando daquilo que seria apresentado.

A divulgação institucional esteve sempre presente na exibição do Túnel da Ciência. Além dos painéis com conteúdos relativos aos resultados das pesquisas concebidas no Instituto Max Planck, havia também um espaço intitulado "cinema" em que era exibida a história da instituição. Nas entrevistas com os visitantes após suas visitas, era latente a identificação que eles faziam entre a exposição e o Instituto Max Planck.

Apesar disso, Tiago acredita que houve uma subversão dos motivos envolvidos na exibição do Túnel da Ciência no Brasil. Para justificar tal argumento, ele aponta o modelo implantado pelos monitores, que na percepção do Tiago, mudou a lógica expositiva:

37 - TIAGO: Então muitos deles se especializaram em algumas áreas e o projeto mudou. No começo, o representante do Max Planck queria que eles girassem, alternassem entre os módulos, mas não foi bem o que aconteceu.

[...]

41 - TIAGO: Aí vem a subversão, como qualquer ação humana você pode subverter. $\mathrm{O}$ aluno que subverte a aula do professor, o diretor que subverte as orientações da secretaria de educação, a maneira como o Brasil subverteu a exposição mudou o objetivo da exposição, a exposição aqui...certamente os alunos de graduação devem ter conhecido o Instituto Max Planck graças à exposição que é um dos objetivos do Max Planck, mas no Brasil, ali em São Paulo, o grande uso da exposição foi um veículo para divulgar a Ciência e Tecnologia mesmo e aí entrou o trabalho dos mediadores. 
Novamente, vemos os profissionais da monitoria no centro da mudança das atividades que envolvem a vinda da exposição ao Brasil. Inicialmente, havia uma regra clara estabelecida pelo Rafael sobre a forma como os monitores deveriam atuar circulando entre os módulos. Entretanto, ao longo de seu trabalho, eles subvertem essa ideia e acabam atuando fixos em um módulo expositivo, se especializando naquele assunto e permitindo encontrar, em pouco tempo, pontos de diálogos com o público, em meio a seus discursos. Na visão do Tiago, a introdução dessa forma de atuar leva à inclusão de novos objetivos à atividade de significação da exposição e, assim, além de promover a divulgação institucional, no caso do Brasil, a exposição transforma-se em um veículo para abordar Ciência e Tecnologia.

Vê-se claramente que há múltiplos motivos em torno da exposição, criando uma tensão entre divulgar o Instituto Max Planck versus divulgar a Ciência. Entretanto, o trabalho dos monitores gera uma nova síntese para essa tensão que é obtida a partir da subversão em relação aos objetivos estabelecidos pelo Instituto Max Planck.

5.2.2 Aprender conteúdos científicos $\mathrm{x}$ explorar os aparatos interativos

Apesar dos conteúdos das contradições apontarem para dualidade, precisamos entender que eles ilustram núcleos que evidenciam direcionamentos que caracterizam as atividades analisadas, assim, não queremos propor que a interação com os aparatos museais não propiciam a aprendizagem das Ciências, mas que existe uma tensão, no caso analisado, decorrente da forma como os participantes encaram a visitação à exposição.

A emergência dessa contradição permeou a interação entre os visitantes espontâneos e o Túnel da Ciência, como podemos ver no caso da Família 2, composta pela mãe 2 (graduação em Direito) e filha 2 ( 6 anos), residente na cidade de São Paulo, frequentadora de museus para conhecimento de outras culturas, e que permaneceu na exposição durante 34 minutos.

Como já relatado, ao questionar a mãe 2 sobre os motivos de visitarem a exposição, é indicada a aprendizagem de conteúdos científicos como o principal ponto, evidenciando a importância que a mãe atribuia para esse motivo.

Nesse sentido, podemos entender que, para essa mãe, o objeto com que interagem seriam os conhecimentos científicos expostos. Esse fato é marcante nas 
diversas situações em que a mãe orienta a filha quanto aos conteúdos científicos presentes na exposição e que podem ser importantes para ela, estimulando ações como leitura dos painéis, atenção às explicações dos monitores, entre outras.

Visita da Família 2

Trecho 120 - Mãe 2: Vem oh, dá uma olhada com calma. Olha que legal filha, já sabe ler né? Então se joga.

Trecho 121 - Mãe 2: Olha mistura de raças, acho que tá falando isso. Isso não é foto, não é pra você mexer (Aponta para um painel sobre raças e genética. Filha tenta mexer no painel achando que é touchscreen).

Em outro momento:

Visita da Família 2

Trecho 150 - Mãe 2: Filha vem aqui, isso é importante de você aprender.

(Mãe chama a filha para perto da máquina que simula a ressonância magnética funcional)

Trecho 151 - Tá vendo ela tá apertando ali e tá acendendo aqui pra saber qual região é responsável. Não essa feira é necessária mais vezes. Você viu filha? Presta atenção você é muito ansiosa

Um tensão que podemos apontar ocorre entre as atividades da mãe e da filha.

Fica claro, em alguns momentos da exposição, que o objeto a que é direcionada a atividade da filha é diferente do de sua mãe. Podemos entender que há diferenciação pois, de um lado, a filha queria explorar os totens com vídeos, escutar com o fone e interagir com os objetos da exposição e, de outro, a mãe focava sua atividade em compreender os conteúdos científicos, desejando que a filha também o fizesse.
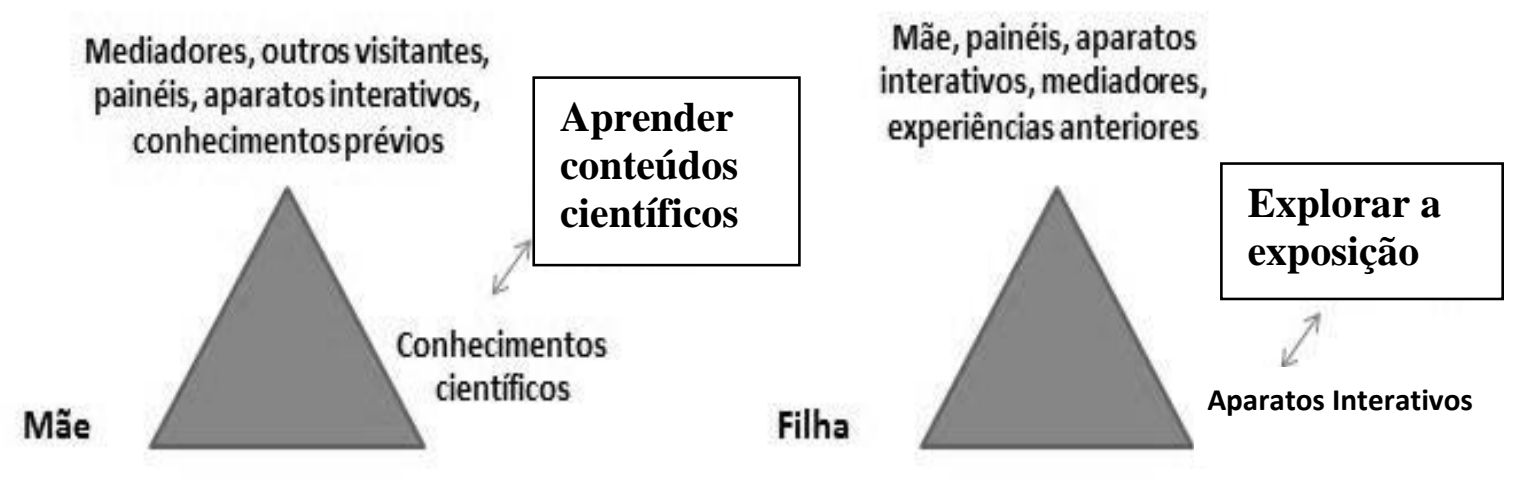

Figura 25 - (à esquerda) Modelo de atividades de mãe (visitação focada nos conteúdos científicos), (à direita) Modelo de atividade da filha (visitação focada na exploração dos aparatos interativos). Fonte: autoria própria. 
Entendemos, assim, que o objeto da criança eram os aparatos museais que se relacionam com a sua necessidade de compreender a exposição e o objeto da mãe, os conhecimentos científicos que se relacionam com sua necessidade de aprender ciências. Essa tensão entre diferentes atividades em grupos de visitação se fez presentes em outras famílias, indicando uma necessidade de se pensar na heterogenidade dos públicos das exposições científicas, os seus múltiplos motivos e das diferentes formas de visitação que podemos estabelecer.

\subsection{A EXPOSIÇÃo}

\subsubsection{Modelos dialógicos $x$ valores universais}

Um questionamento que podemos fazer em relação à itinerância das exposições é como estabelecer e incorporar as especificidades das comunidades as quais a exposição está visitando. Segundo Teixeira Coelho Neto (1997, p. 12), "não é apenas chegar ao distante geográfico, mas também ao social, às produções culturais, a fim de vivificar o patrimônio e a cultura local". Ao afirmar que "Quanto mais uma exposição é concebida e realizada perto de seu público, mais ela tem a chance de cumprir suas três missões de comunicação, de informação e de educação" (Varine-Bohan, 1979, p.3), o autor nos expõe a um grande desafio no âmbito da itinerância, pois boa parte das exposições semelhantes ao Túnel da Ciência é realizada "longe de seu local de acolhimento e sem grandes relações com as populações visitadas e seu patrimônio local”, (XAVIER, 2014, p. 12). Ainda segundo essa autora, a preocupação com o público das exposições, e não apenas com o acervo ou o discurso expográfico, considera o caráter relacional do patrimônio. Aponta, ainda para uma perspectiva dialógica, ao valorizar a interação com as especificidades locais em detrimento a um modelo unidirecional, atendendo, assim, de forma mais coerente às funções educativa e social dos museus.

Como vemos, já podemos localizar que existe uma tensão histórica em relação à atividade de itinerância das exposições no que tange a incorporação de um modelo dialógico. Porém, como essa tensão aparece no caso do Túnel da Ciência?

A primeira questão que trazemos diz respeito à concepção do que seria algo dialógico para Rafael, que participou da concepção do Túnel da Ciência, bem como a forma como ele enxerga tal modelo na exposição. Ao falar sobre sua experiência 
no Deutsches Museum, o entrevistado ressalta um modelo desenvolvido por ele, o qual intitula de "dialógico":

Trecho 16 - RAFAEL: Tivemos a ideia de falar com os cientistas e tecnólogos sobre os seus desenvolvimentos cientifícos, de suas ideias em seus campos, ou melhor, falar com deles de um determinado tópico. Eu desenvolvi um conceito que eu chamaria dialógico. Eles falavam sobre os seus temas, e foi quando vimos que havia algo como uma rede que ligava as diferentes áreas [...] . Verificando isso, possibilitamos que essas pessoas conversasem em conjunto, em um processo dialógico.

Para o entrevistado, o modelo dialógico se concretiza na aproximação entre dois polos distintos em uma conversa, mas isso não se reflete na concepção do modelo dialógico de exposição. Para o representante, o modelo dialógico está na geração do discurso exposto, em que houve o diálogo entre diferentes cientistas, sendo inexistente na proposta expositiva, como vemos abaixo:

Trecho 59. PESQUISADOR: Ontem você estava falando que precisamos sair do modelo de déficit de comunicação para um modelo mais dialógico. O que você acha sobre este exemplo, você acha que esse Túnel da Ciência tem um modelo mais dialógico?

Trecho 60. RAFAEL: Não, realmente o Túnel não é um modelo dialógico. É realmente mais uma apresentação ex cathedra. Porque a coisa mais simples é que usamos imagens coloridas nos módulos temáticos. Estamos cientes do fato de que os resultados da investigação são fundamentais, ao mesmo tempo, sabemos que a forma como nós apresentamos não são compreensíveis para a maioria dos visitantes.

[...]

Trecho 65. PESQUISADOR: E o que você acha que seria um bom instrumento... se você quer fazer uma exposição em um modelo dialógico, como poderia ser feita?

[...]

Trecho 66. RAFAEL: Bem, de forma simples, podemos usar telas sensíveis ao toque e tentar fazer as pessoas usarem alguma coisa, para fazer algo que poderia ajudá-las a ficar um pouco mais interessadas. Mas dialógica seria como temos aqui, esta é a única coisa que com o iPod você poderia chegar a um marcador e, em seguida, fazer perguntas e então eles responderiam. Esta é a única parte dialógica (Tradução nossa).

Entendemos que há uma tensão em relação ao uso do modelo dialógico, que passa por uma necessidade de incorporação desse instrumento na atividade de concepção da exposição. Rafael considera que a exposição não privilegia a dialogicidade, interpretada por ele principalmente como interatividade física, o que leva a uma dificuldade de compreensão por parte dos visitantes, afetando assim a atividade de visitação. 
Inicialmente, foi discutido sobre a possibilidade de se realizar uma versão brasileira do Túnel da Ciência, porém, após refletir sobre o conteúdo da exposição, Tiago aponta que não há intenção de produzir algo semelhante no país porque acredita que a forma como é apresentada é muito distanciada da realidade brasileira:

60 - TIAGO - uma exposição que traz uma ideia do valor universal porque é uma exposição itinerante, é a mesma exposição que vai para a China é aquilo, ela vai pra Rússia é aquilo, a única coisa que muda é a tradução, a língua. Por mais que... acho que foi na Rússia ou a China que tentaram criar um anexo, uma coisa mais específica... a única coisa que muda é a tradução. A exposição é bacana, tem méritos incríveis, de fato você fazer uma exposição que lide com temas complexos, de ponta é uma coisa muito bem-vinda sim, mas é uma exposição que é muito descolada da realidade brasileira, entendeu?

Ao mesmo tempo em que há um desacordo no discurso do Tiago em relação ao modelo da exposição, ao refletir sobre sua atividade, que envolve 0 desenvolvimento e financiamento de políticas públicas para popularização da Ciência no país, afirma que seria impossível no Brasil apoiar apenas ações que privilegiasse o dialógico, indicando que essa é uma contradição latente nas discussões sobre a divulgação das Ciências.

64 - TIAGO: [...] a divulgação em Ciência no Brasil, a gente ainda vive um modelo que a nossa primeira opção ainda é mais... a gente ainda precisa de mais... Claro, a classificação é importante, a gente hoje vive discutindo a importância de um processo dialógico mas se você for olhar uma parte das ações de divulgação em Ciências no Brasil ainda é de mão única e a gente não pode dizer que a partir de hoje o MCTI não vai mais financiar ações de divulgação que partam do princípio de Ciência Universal, é loucura!

Tiago ressalta a necessidade de encontrar mecanismos dialógicos que permitam transformar a sua atividade a fim de permitir que os processos de divulgação e popularização das Ciências avancem para as especificidades das diversas realidades brasileiras:

Trecho 45 - Representante do MCTIC: [...] A gente está vendo como, de fato, urgente para o Brasil é centrar naquilo que a gente entende como desafios, que é além de atingir mais brasileiros, ampliar as audiências, então fazer divulgação, e aí divulgação nem é o termo mais a ser usado, seria, enfim independente do termo... seria usar e desenvolver processos dialógicos e aí ela vai se especializar. Você fazer divulgação em uma periferia urbana, para os quilombolas, para os grupos indígenas, para os ribeirinhos, ou para as comunidades indígenas, então o que a gente quer focar como prioritário é desenvolver mecanismos. 
E aponta que, mesmo a exposição tendo um caráter estrutural rígido com poucas adaptações para um processo dialógico, os monitores acabaram subvertendo essa lógica ao abrir espaço para uma mediação menos unidirecional, citando um episódio que presenciou:

67 - TIAGO: [...] uma coisa seria se os mediadores não existissem [...] aquilo teria sido, para esse grupo de visitantes uma experiência do tipo: "Ahn? O que é aquilo? Ah é bonito!" muito do que aconteceu lá não teria acontecido, mas em virtude do trabalho dos mediadores, eles conseguiram fazer essa ponte. Você viu que à medida que eles foram se especializando na mediação eles foram progressivamente construindo um discurso que re-significava aquele discurso científico da exposição, em analogias, em linguagens cotidianas... Era o jeito de ter algum diálogo ali, mas acredito que os mediadores conseguiram, apesar do jeito da exposição, o trabalho dos mediadores conseguiu cobrir essa lacuna.

Novamente, podemos perceber como a atuação e engajamento dos monitores em suas atividades abre possibilidades para mudanças em relação à significação do Túnel da Ciência no Brasil, incorporando elementos que possibilitem um modelo de discurso que ultrapasse uma perspectiva meramente unidirecional. Segundo Teixeira Coelho Neto (1997), o pensar museológico ${ }^{26}$ deve refletir sobre a necessidade de atuação da comunidade junto às ações museológicas, devendo se configurar como uma das principais bandeiras dessas instituições. A constituição de metodologias museológicas participativas e a transformação das pessoas envolvidas, de meras espectadoras a agentes do patrimônio, caminham para um fazer museológico em que se estabelece um diálogo efetivo entre as populações estudadas e os objetos de sua cultura.

Pensando nesse sentido e sobre a itinerância das exposições, Xavier (2014) indica que a mobilidade geográfica, enquanto estratégia dessas exposições, não deve se ater apenas a fazer chegar um conhecimento produzido por determinada instituição a uma população distante, mas deve abrir espaços em seus discursos expositivos para trabalhar, com a própria comunidade, os entendimentos e usos do seu patrimônio visando a transformação social.

\footnotetext{
${ }^{26}$ Apesar de ser desenvolvido por uma instituição científica, o Túnel da Ciência carrega marcadores do discurso museográfico, com saberes dessa área, haja visto que o próprio representante do Max Planck teve sua formação na esfera museal, atuando nessa área durante alguns anos.
} 
5.3.2. Interatividade: discurso midiático $\mathrm{x}$ discurso expositivo

Conforme já apresentamos, a Produtora Geração foi a empresa responsável pelo contato com a imprensa e pela divulgação da exposição. $O$ foco da divulgação recaiu no ineditismo da exposição e nos seus elementos "interativos". Advertimos que o adjetivo "interativo" pode assumir diversos significados no campo da educação não formal e, nesse caso, identificamos que ele foi usado para explorar a ideia de que a exposição contava com diversos aparatos que poderiam ser manipulados pelo visitante. Essa percepção pauta-se no discurso do Marcelo, em que explica quais características eram utilizadas por eles para divulgação:

Trecho 40 - MARCELO: Nós exploramos muito a questão da interatividade! Um passeio pelo futuro, a mais interativa exposição em educação para ciência, a mais moderna exposição do mundo. Sempre esses atributos que do ponto de vista de pesquisa não tenha uma exposição que apresente a pesquisa com tantas informações tão novas e que ainda estão sendo objetos de pesquisa dos cientistas.

Foi possível identificar que muitos desses adjetivos estavam no discurso dos visitantes quanto questionados sobre a motivação para visitar a exposição, ou seja, foi criada uma expectativa a partir do que foi divulgado e explorado pela grande mídia. Isabel (Família 3) aponta a interatividade como algo que chamou atenção na divulgação:

Trecho 22 - ISABEL: Uma reportagem na televisão e indicação de amigos, e como vimos que as imagens da exposição eram muito bonitas e tinham coisas interativas decidimos vir.

Os monitores entrevistados relataram a frustração de alguns visitantes, que criaram expectativas a respeito do espelho mágico, um aparato que simula uma visão interna do corpo humano:

Trecho 44 - DAIANE: Eu acho, uma mulher que chegou para mim e falou assim "é só isso? Não tem outro andar?" "não é só isso", senti uma expectativa frustrada, quando viam o que foi anunciado no Jornal Nacional sobre o espelho mágico, uma mulher grávida achava que ia ver o bebê, uma outra que fez uma cirurgia no fígado acha que ia ver como estava o fígado, então tinha toda uma visão mágica em cima daquilo que a televisão noticiou.

Apesar da frustração de alguns visitantes, os aparatos que permitiam a manipulação chamavam bastante atenção do público espontâneo. Podemos 
questionar, então, como ocorria essa interação. No trecho abaixo, extraído da gravação da visita da Família 1, composta pela Roberta (mãe) e Gabriel (filho), os visitantes estão no módulo temático "Saúde", tentando interagir com o aparato que atribui coloração à sua imagem de acordo com a temperatura corporal.

Trecho 146 - 150: Visita da Família 1

(Mãe e filho se direcionam para o simulador de temperatura corporal) 146 - ROBERTA: Olha lá você! Por que será que têm umas regiões que estão vermelhas?

147 - GABRIEL: Hum... Estou em dúvida.

148 - ROBERTA: Será que eu estou quente no mesmo lugar? Por que será que alguns lugares são mais vermelhos, queria perguntar para a monitora, mas ela está ocupada, uma pena!

149 - GABRIEL: Vamos.

150 - ROBERTA: Vamos embora então.

Esse padrão de comportamento se repetiu em diversos episódios das visitações das famílias e nos indica que, apesar dos aparatos interativos atraírem os visitantes, os instrumentos presentes em seus sistemas de atividade não eram suficientes para que houvesse um engajamento na situação.

Vemos novamente a figura do monitor permeando as necessidades dos visitantes que se deparam com uma expectativa de poder manipular os aparatos interativos, mas que não o conseguem fazer por não compreenderem a proposta. Tal relato é reforçado pela monitora Isabela em sua entrevista:

Trecho 26 - ISABELA: Papel do monitor? É muito importante! É um papel de...traduzir mesmo o que está escrito ali, porque quando a exposição, quando você só olha assim ela parece um pouco chata, eles querem passar uma ideia de que é muito interativo e tudo mais, mas a maioria não é, são muitos painéis, é texto para ler, parece ser chato, mesmo os aparatos, muitas vezes é difícil compreender a mensagem por trás.

Qual o limite do discurso midiático em torno da divulgação de uma exposição científica? Segundo Xavier (2014, p.54), dosar a exploração da "interatividade" é essencial para manter um ambiente reflexivo para $o$ visitante e não apenas sensorial:

Ao analisarmos essas exposições grandiosas, frequentemente divulgadas pelos meios de comunicação com anúncios em jornais ou mesmo em matérias televisivas, percebe-se que as tendências museológicas acompanham também a espetacularização dos museus, que se utilizam cada vez mais da alta tecnologia para criar recursos interativos, fazendo da exposição um show extraordinário de imagens e sons. A utilização desses recursos não necessariamente é vista de maneira positiva, pois, se empregados 
em excesso, podem encobrir o tempo de reflexão necessário à interpretação do bem patrimonial, passando a exposição a configurar-se tão somente como um conjunto de experiências sensoriais, eclipsando a necessidade de um contato mais direto e reflexivo com o que é visto.

Podemos entender que a tensão que perpassa a formação de público envolve superar uma contradição entre o discurso vinculado à divulgação da exposição e o contexto expositivo. Buscar soluções para tal superação pode criar uma experiência mais proveitosa para o visitante.

\subsection{GESTÃO}

\subsubsection{Negociações entre o prometido e o efetivado}

A itinerância de uma grande exposição científica internacional pressupõe uma série de acordos que precisam ser efetivados entre os países e as empresas envolvidas. Tais combinados viabilizam a exibição dessas exposições, porém, em algumas situações, alguns deles não podem ser concretizados, gerando contradição entre o prometido e o efetivado e exigindo reestruturações nos sistemas de atividades envolvidos e na relação entre eles.

Como aponta Xavier (2014), a dinamização de uma exposição resulta em especificidades que devem ser incorporadas nos projetos de itinerância e, assim, devido a sua natureza, o projeto da exposição itinerante necessita levar em consideração várias questões. Dentre elas, ressalta-se a necessidade de flexibilidade em termos de planejamento, de forma que possa ser provida em diferentes tamanhos e formas de espaços expositivos, e de facilidade de instalação, manutenção e montagem e desmontagem, assim como facilidade de transporte entre as jurisdições.

No caso da vinda do Túnel da Ciência ao Brasil, houve mais de uma tentativa com o objetivo de trazer a exposição ao nosso país. A primeira delas acabou não se concretizando, o que gerou frustração e descontentamento por parte dos profissionais do Instituto Max Planck, conforme relata Tiago:

23. TIAGO: As negociações, elas começaram antes de eu ir para o Ministério, né? Eu sei que a SBPC de Natal, acho que foi em 2010, eu lembro que na SBPC de 2010 quando o MCTI na SBPC de 2010 tinha um espaço chamado Expotec... Então o Ildeu, que na época era diretor do departamento, falou que em um dia do evento iria 
trazer um representante do Max Planck para falar sobre o Túnel da Ciência. Foi o primeiro contato que eu tive mas eu sei que naquele período não houve sucesso [...] não necessariamente porque o MCTI não teria recurso naquela época mas se descobriu ao "51 do segundo tempo" que o MCTI não teria como transferir recursos para o Max Planck. Disseram que a reunião que informaram isso ao representante do Max Planck foi a coisa mais apavorante do mundo, aonde ele imaginou que ele iria lá assinar mas disseram para ele que era impossível. Mas eu sei que essa primeira tentativa não aconteceu por causa desse entrave, por causa da transferência de recursos do MCTI para o Max Planck.

Entendemos que foi criada uma contradição que permeia a relação que abrange aquilo que foi planejado e o efetivado. Assim, ao não garantir o financiamento combinado com o Instituto Max Plank pelo MCTIC, foi suprimido o recurso financeiro como instrumento da atividade de concepção e vinda da exposição, gerando um conflito em relação a como o Max Plank enxerga o papel do MCTIC. Assim, o representante desse Instituto não reconhece as contribuições exercidas pela entidade brasileira. Essa troca de ideias incompatíveis parece evidenciar que há uma tensão que não foi superada.

Trecho 88 - Entrevistador: Nós estamos o [Túnel da Ciência] trazendo para o Brasil. Como foi a negociação para trazer o Túnel da Ciência?

[...]

Trecho 89 - Rafael: Essa foi a parte mais difícil de todas. Quatro anos de preparação, mas, finalmente, com a ajuda de políticos alemães e empresas alemãs. Não foi a ajuda do seu presidente, sinto muito dizer isso...

$[\ldots]$

Trecho 91 - Rafael: Em Moscou (...) Foi realmente como tínhamos escrito nos acordos. Quer dizer, o Brasil foi um parceiro muito bom, por sua vez, mas foi muito difícil encontrar o dinheiro. E foi muito difícil (...) para transferir o dinheiro do Brasil para a Alemanha, os serviços de escritórios oficiais foram fornecidos de lá.

Vemos, nesse exemplo, que foi necessário reestruturar a atividade que envolve a vinda da exposição ao Brasil. Foi proposto, a partir disso, um segundo modelo, anos depois, no qual, por meio da intermediação do Cônsul da Alemanha, a Produtora Geração estabeleceu uma parceria com o Instituto Max Planck para trazer a exposição ao Brasil:

Trecho 28. MARCELO: Isso começou em fevereiro de 2012, quando o Cônsul Honorário da Alemanha em Minas, conhecendo o nosso trabalho, sabendo o que a gente faz, nos contou sobre a frustração do governo alemão de não ter conseguido trazer o Túnel da Ciência na primeira vez. E aí, ele nos perguntou se a gente tinha interesse em conversar com o governo da Alemanha para ver se a gente 
contribuía nesse processo com a nossa experiência e com aquilo que a gente já tinha feito. Isso foi em fevereiro, especificamente dia 12 ou 13 de fevereiro. Duas semanas depois a gente já estava em contato com a Sociedade Max Planck.

Como podemos perceber, a saída encontrada para a superação da contradição planejado $x$ efetivado foi a inclusão de um novo participante em um novo modelo de atividade. Porém, ressalta-se que, mesmo com uma nova estruturação da atividade, existem tensões que permanecem na forma como esses participantes reconhecem (ou não) o papel do outro. Inclusive com a não inclusão da Produtora Geração entre os responsáveis pela efetivação da exposição elencados pelo Max Planck. Tal configuração, ao que parece no excerto acima, colidiu com as formas usuais que, até então, o Max Planck negociava a ida da exposição para os diferentes países. Essas tensões podem ser reveladas por meio de dúvidas, questionamentos, críticas, e são fortes indicativos de tensões acumuladas ao longo do tempo no sistema de atividade central, o que gerou a busca pelo segundo modelo.

Como aponta Daniels (2011), as atividades são sistemas abertos e, por isso, a introdução de algo novo, como por exemplo, um novo sujeito ou instrumento, pode ir de encontro, chocar-se com um elemento antigo e, desse modo, provocar tensões. Nesse caso, o elemento novo foi a introdução da produtora Geração como a principal instituição responsável pela vinda da exposição ao país, que após um alinhamento entre seus ideais e os do Instituto Max Planck, assumiu a orquestração da vinda da exposição.

5.4.2 Formalização institucional da concepção de divulgação científica $x$ instabilidade política

Outra questão importante que estabelece uma relação com as contradições anteriores diz respeito a como a experiência da vinda do Túnel da Ciência ao Brasil altera o sistema de atividade do MCTIC. Quando indagamos Tiago sobre as contribuições que a vinda do Túnel da Ciência trouxe para o Ministério, fica claro que alguns instrumentos passam a ser incorporados na atividade da instituição. Os principais deles são a forma de financiamento de projetos de popularização da Ciência (como já visto na contradição financiamento público x privado) e os modos 
de concretização dessas ações com poucos recursos:

Trecho 27 - TIAGO: (...) o fato de boa parte dos recursos serem de empresas privadas e viabilizados por outra empresa privada que ganhou evidentemente dinheiro, não há crime nisso nenhum, é um projeto que a gente tem que ver se queremos se apropriar desse modelo e tentar expandi-lo. (...) um legado interessante também, uma exposição que sensibilizou a mídia, então essas coisas aconteceram numa ecologia, né. Então você vê que fica um legado: primeiro para os profissionais dos museus, fica um legado para os gestores de divulgação de Ciências que vê um modelo que o poder público gastou pouco, fica um legado para o sistema privado que aprendeu a articular as coisas e fica um caminho. Então assim o resultado foi positivo, agora a questão é aprofundar.

Apesar de reconhecer tais contribuições que resultaram da vinda da exposição ao Brasil, Tiago relata mais adiante na sua entrevista que a instabilidade política interfere na perpetuação do legado proveniente dessas experiências. Encontramos, assim, a partir do trecho abaixo um conflito que indica uma tensão relacionada a questões políticas que interferem no desenvolvimento da atividade do MCTIC. Há um desacordo manifestado pelo Tiago em relação à estrutura organizacional, pelo fato dessa questão afetar o resultado da atividade. Diante de tal contradição, Tiago busca operar transformações em sua atividade e, assim, tenta, por meio de sua atuação, materializar as diretrizes de divulgação científica do departamento, considerando a formalização de uma proposta oficial de divulgação científica para o Ministério que superaria a rotatividade de diretores no MCTIC e seus departamentos.

Trecho 17 - TIAGO: Essa é uma questão muito complicada, na verdade eu estou até elaborando um texto que eu quero vender dentro do MCTI com isso aqui e agora, o que o MCTI entende por divulgação e difusão de Ciência e Tecnologia. Nesse tempo lá, eu senti falta disso porque se muda o diretor, muda o secretário, as pessoas tiram coisas das suas respectivas cartolas. $O$ departamento conseguiu um eixo porque houve uma estabilidade política que permitiu que um diretor ficasse à frente do departamento por oito anos. Isso foi crucial, isso foi extremamente importante. Isso é muito incomum, mas qual é o medo? Isso provavelmente não vai se repetir, a gente vive um cenário político de total instabilidade, 0 governo federal vive fazendo acordos com partidos de oposição ou partidos aliados que em última instância significa troca de cargos. Então eu vejo isso como uma coisa ruim, mas isso nos obriga a gerar uma política de divulgação que seja formalizada. Eu espero ter um tempo mínimo para formalizar isso, lógico que eu vou apresentar isso ao secretário da SECIS, vou apresentar isso ao ministro, mas a ideia é o seguinte: passou por eles, teve o aval, isso agora vai ser apresentado como o que o MCTI entende por divulgação de Ciências e Tecnologia. 
Vemos que a concretização de tais ideias não é automática e envolve embates internos e externos. A vinda do Túnel da Ciência ao Brasil faz evidenciar, na visão do representante do MCTIC, a necessidade de superação da tensão organizacional presente no departamento, materializada em um documento em que os valores envolvidos com o financiamento das ações de divulgação científica no país possam se constituir como um instrumento necessário para a atividade de desenvolvimento e execução de políticas públicas de divulgação científica. Nesse cenário, podemos entender que há a busca pela implementação de mudanças que compreende a busca por uma formulação das diretrizes da atividade do MCTIC, e que a experiência com o Túnel da Ciência fornece elementos que são incorporados nesse processo.

\subsection{MONITORIA}

\subsubsection{Teoria $\mathrm{x}$ prática de monitoria}

No Brasil, a presença de estudantes como monitores da exposição, atuando como um elo entre o público e exposição foi decorrente de uma parceria com a Universidade Federal de São Paulo (UNIFESP), instituição responsável pela seleção de alunos de graduação e pós-graduação, que possuíam formação em áreas relacionadas às temáticas que seriam apresentadas. Tal parceria foi efetivada via MCTIC, órgão financiador das bolsas. Nesse cenário, localizamos um núcleo forte de tensão que engloba as características necessárias para ser monitor da exposição, a seleção dos alunos e a forma de preparação necessária e possível no contexto de uma exposição que é itinerante e internacional.

A presença de monitores que explicariam a exposição ao público é um elemento novo na visão de Rafael. Segundo ele, na exibição do Túnel da Ciência na Alemanha, os monitores atuam como supervisores, verificando se os visitantes estão fazendo algo não autorizado. Sendo assim, ele ressalta a importância desses profissionais aqui no Brasil:

Trecho 82. RAFAEL: Isso é realizado pelas instituições daqui e que, de certa forma, beneficiam esses jovens, já que eles estão ajudandonos a apresentar a exposição. Isto é, em minha opinião, muito importante, não só a mensagem, mas também a parte conceitual da apresentação. 
Sobre as características para ser um monitor, temos um primeiro ponto de desacordo entre os participantes envolvidos. Na seleção realizada pela UNIFESP e na fala do representante do Instituto Max Planck, observa-se uma característica considerada como relevante para a ação educativa: o domínio, pelos bolsistas, de conhecimentos conceituais sobre os temas que seriam abordados. Marcelo coloca um desacordo em relação à seleção dos profissionais e aponta uma outra característica importante, que é a capacidade de comunicação:

Trecho 44. MARCELO: A gente conseguiu essa parceria com a UNIFESP, uma instituição muito interessada. Eles fizeram uma seleção que a gente não participou. Potencialmente, em uma outra oportunidade, a gente participaria para que a gente pudesse escolher ou usarmos como variável no processo de escolha, a capacidade de comunicação. Talvez na verdade esse seria um princípio importante, não só a questão de domínio de conteúdo, mas a capacidade de comunicação que é o importante em uma exposição como essa, talvez até mais que o domínio do conteúdo.

Todos os monitores entrevistados foram categóricos ao afirmar que nunca atuaram com monitorias e que durante a seleção não sabiam com clareza qual seria a função deles e como seria a exposição. Muitos ressaltaram o pouco contato prévio com a exposição, outros mostraram uma expectativa na formação que poderia fornecer instrumentos para os auxiliarem na atividade de mediação:

Trecho 54. BRENO: A gente teve um dia de treinamento lá na UNIFESP, na Reitoria, e aí a maioria dos monitores estavam presentes e a gente ouviu uma "palestrinha" do Steiner que é um dos organizadores e aí o pessoal da Produtora Geração que é da parte mais comercial da exposição falou um pouquinho com a gente e a gente teve um treinamento presencial que foi um dia anterior e isso foi um pouquinho ruim porque a gente só veio conhecer na véspera a exposição e no outro dia já tinha que trabalhar com todo o conteúdo, impossível.

Os monitores, durante a entrevista, mostraram-se um pouco frustrados com a formação que receberam. Tiago, representante do MCTIC, que também participou da formação dos monitores, comentou sobre a necessidade de uma formação mais adequada, que passasse por questões conceituais em relação à mediação em exposições. Entretanto, pondera que, mesmo frente à formação ocorrida, os profissionais conseguiram atuar de forma satisfatória:

Trecho 50. TIAGO: Então houve pouco tempo para a formação dos monitores, mas apesar de.... Eu sei que a formação dos monitores não passou por questões conceituais de educação não formal, divulgação de Ciências, não passou, mas por outro lado o grupo era extremamente qualificado em termos de formação e isso compensou 
uma não formação não idealizada, né?

O questionamento de Tiago é o ponto central dessa seção: como os alunos, que não tinham experiência em mediação e não receberam uma formação ideal, conseguiram desenvolver uma atividade de mediação satisfatória ao longo de 28 dias de exibição da exposição?

De acordo com Engeström (1999), as tensões podem ocorrer por diversos motivos: implementação de novos procedimentos, exigência de formas de atuação, alteração na divisão de tarefas, supressão de instrumentos da atividade, entre outros. Esses processos geram risco de falta de aceitação e resistência que, caso aconteçam, podem gerar conflitos e paralisar o desenvolvimento de transformações expansivas. Por outro lado, como já ressaltado, as tensões também podem ser fonte de potência e inovação para a atividade.

Sobre isso, a monitora 2 relata que em seu primeiro contato com a exposição percebeu que o conteúdo do módulo temático era muito mais complexo do que o explorado no curso e na apostila. Dessa forma, sentiu a necessidade de procurar outros instrumentos que permitissem acessar esses conhecimentos científicos. Ao analisar essa trajetória, afirma que, "vendo hoje, por um lado, isso foi positivo", pois a estimulou a buscar informações. Percebemos claramente, tanto pela marca linguística "por um lado", quanto pela característica de avaliações incompatíveis, que se trata de um dilema. Nesse trecho, ainda, fica claro como as contradições são dinâmicas a ponto de, no término de sua atuação na exposição, a monitora refletir sobre a mesma questão sob outro ponto de vista.

Tiago também busca explicações para o fato, trazendo os elementos teóricos que julga como necessários para a atuação como monitor e ressaltando que, mesmo na ausência deles, a prática intensa supriu os monitores de elementos necessários para executar suas atividades:

Trecho 50. TIAGO: [...] como o período foi longo e intenso, eles aprenderam. Se você acompanhou os primeiros dias, eles não sabiam, literalmente, o que fazer. Com o tempo, eles foram desenvolvendo estratégias e se especializando em setores da exposição que juro, eu como mediador que fui durante muito tempo, qualifico que da segunda metade da exposição em diante eles estavam atuando bem como mediadores, apesar de não terem lido o manual de mediação do GEENF ou não ter lido alguns capítulos clássicos de educação não formal. Apesar disso, o contato era tão grande e intenso que eles foram aprendendo de maneira meio tácita. Poderia ser melhor? Poderia, mas eu qualifico que o que eu assisti foi bom. 
Sobre a formação teórica e prática de monitores que atuam em museus de Ciências, Gomes e Cazelli (2016) apontam que ela não ocorre apenas por ações organizadas pela instituição, mas envolve saberes disciplinares, de formação profissional e de experiência. Por ser uma atividade complexa, a formação desses profissionais deve abarcar diferentes estratégias e promover trocas de experiências.

Esta contradição entre teoria e prática na mediação em exposições vem à tona fortemente em situações como a que estamos pesquisando, em que se tem uma exposição itinerante com um conteúdo pronto e com pouco tempo para preparação prévia. Vemos que, sobre essa contradição, os monitores buscaram testar formas de atuação, incorporando instrumentos que os auxiliassem a satisfazer a necessidade de suas atividades.

Segundo Rocha (2018), que analisou a itinerância em exposições científicas, um dos fatores que dificultam essa prática é a constituição de uma equipe de monitores bem formada e alinhada com a proposta. Esses profissionais são fundamentais porque representam um elo entre a exposição, a instituição e o público. Apesar de serem considerados importantes, esses profissionais sofrem com uma carreira precarizada e com a falta de formalização da profissição (CARLÉTTI; MASSARANI, 2015). Podemos citar também a ausência de estruturas formativas, o que dificulta a identidade de monitoria que englobe elementos teóricos e práticos, como vemos no caso estudado.

5.5.2. Monitoria junto ao público escolar $x$ mediação junto ao público espontâneo

Conforme vimos, os monitores foram desenvolvendo um repertório de estratégias educativas à medida que atuavam na exposição. Entretanto, as regras do sistema de atividade de mediação tiveram interferência direta da Produtora Geração. Tal relação gerou um núcleo de tensão que resultou em uma contradição no que tange $o$ atendimento ao público.

Dentre sas regras, estava a prioridade ao atendimento do público escolar. Durante os preparativos para a exibição da exposição, foi feito um esforço por parte da Produtora Geração e do MCTIC para a formação de público para a exposição, por meio de uma parceria com a Secretaria Municipal de Educação da cidade de 
São Paulo. A cada dia de exibição da exposição, grupos de estudantes do ensino fundamental II visitaram a mostra, fazendo um percurso determinado pela produtora e sendo atendidos a cada módulo por um monitor. Esse percurso era cronometrado a fim de manter o controle do fluxo de pessoas. Além dos escolares, a exposição foi aberta ao público espontâneo, porém, nesse caso, a mediação não era garantida, devido ao número de profissionais.

Os monitores indicaram, nas entrevistas, que havia uma tensão no atendimento ao público. Breno apontou a reclamação de alguns visitantes sobre o assunto e a orientação de diferenciação de públicos, evidenciando que eles se encontravam em uma situação sem solução, caracterizada como duplo-vínculo:

Trecho 84 - BRENO: Então, têm uns visitantes que já criticaram que deveria ter para mais pessoas para atender o público, mas não temos o que fazer, a gente é orientado para dar preferência aos grupos escolares, se tiver alguns visitantes em grupo de três e chegar um grupo escolar a gente tem que pedir licença e aí eles ficam sem acesso à interação. Seria mais interessante se tivesse para todos.

Dado esse contexto é importante refletir sobre a seguinte questão: de que forma essa regulação das regras da atividade dos monitores afeta a atividade de visitação do público espontâneo?

Para isso, extraímos um episódios da visita de duas famílias. No primeiro deles, Tina (mãe da família 2) tenta ao longo da visita, sucessivamente, aproximarse dos conteúdos científicos presentes na exposição, solicitando muitas vezes o auxílio de outros visitantes.

Trecho 126 - 128: Visita da Família 2

Trecho 126 - TINA: Que que é aqui gente? (Aborda um grupo de visitantes).

Trecho 127 - OUTRA VISITANTE: É sobre a medicina do amanhã, né?

Trecho 128 - TINA: Nossa achei que deveria ter alguém pra ir explicando, né?

Como, em geral, os monitores atuavam prioritariamente no atendimento das visitas escolares, a mãe aponta dificuldades no entendimento da exposição, até um ponto em que desiste:

Visita da Família 2

Trecho 200 - TINA: O que que é isso?

Trecho 201 - OUTRA VISITANTE: eu acho que é a temperatura.

Trecho 202 - TINA: Ah é!

Trecho 203 - TINA: Do que, de todo lugar? 
Trecho 204 - OUTRA VISITANTE: É. Trecho 205 - TINA: Ah! Não tô entendendo nada! Vamos embora filha.

Em um primeiro momento, é possível identificar um conflito claro que envolve os sujeitos monitores, dos quais a mãe necessita em sua atividade, bem como a presença de regras compartilhadas com o sistema de atividade dos monitores. A ausência de monitores que pudessem dar suporte ao entendimento da exposição decorre do fato de que esses devem dar prioridade ao atendimento às escolas. Sem conseguir entender os conceitos da exposição, a mãe recorre a outros visitantes.

Podemos buscar explicações para a situação apresentada nos apontamentos de Vygotsky sobre as zonas de desenvolvimento proximal (ZDP). Podemos entender a ZDP como a distância entre o nível de desenvolvimento atual, que é aquele em que $\mathrm{o}$ indivíduo consegue resolver problemas sozinhos, e o nível de desenvolvimento potencial, que marca os problemas que o indivíduo consegue resolver em colaboração com alguém mais experiente, com maior expertise (VIGOTSKI, 2001).

No caso apresentado, tanto a mãe como a filha, em diversos momentos, necessitaram de uma aproximação de um monitor que tinha um conhecimento maior sobre dos conteúdos da exposição. Assim, podemos afirmar que existe uma tensão entre a atividade dos visitantes e a atividade dos monitores.

O outro episódio diz respeito à família 3, composta por Isabel (mãe), Rafaela (filha) e Juliana (filha). O padrão de visitação da família é marcado por constante diálogo entre mãe e filhas, sendo que, em muitas situações, a mãe conseguia atender às dúvidas das filhas. No dia da visitação dessa família, a exposição recebeu poucas escolas e, assim, os monitores estavam mais disponíveis. Vejamos o trecho abaixo:

Trecho 75-82: Visita da família 3

Trecho 75 RAFAELA: O que era aquilo que você estava vendo? Trecho 77 RAFAELA: Nossa que complexo.

Trecho 78 ISABEL: (Isabel retorna ao painel com as filhas) [...] Ele falou que na verdade é a mesma galáxia que a nossa, via láctea, só que com... fotos imagens diferentes. Você pode explicar novamente para a minha filha que ela está com dúvidas.

Trecho 79 MONITOR: Aqui é óptico, como se a gente pegasse um telescópio normal, aqui é infravermelho, calor, né? Aqui é raio-x, com uma composição do óptico atrás para a gente entender. Por que a gente observa em vários comprimentos de onda? Por que a luz é 
uma onda, ela tem energias diferentes, dependendo do comprimento. Aqui nessa região alaranjada é a região de formação de estrelas na galáxia de Andrômeda, então se a gente observar aqui, toda essa parte aqui, exceto o núcleo, forma estrelas.

Trecho 80 ISABEL: A Terra não está aí não, Rafaela, essa galáxia aí é vizinha da nossa.

Trecho 81 MONITOR: Ela faz parte dos grupos locais de galáxias, composta por três, Andrômeda é uma delas, a nossa a Via Láctea e a Triângulo e tem várias outras galáxias pequenas, por exemplo, as nuvens de Magalhães que podem ser vistas do hemisfério Sul.

Trecho 82 ISABEL: Obrigado!

$\mathrm{Na}$ situação apresentada Isabel recorre ao monitor duas vezes, corrigindo uma informação que ela havia entendido de forma incorreta, esclarecendo à filha que a galáxia que elas haviam visto no painel não era a nossa (Via Láctea). Nesse contexto, podemos entender que a família 3, com a disponibilidade do monitor, consegue avançar em ciclo expansivo de aprendizagem, mostrando a importância desse profissional em uma exposição complexa como essa.

\subsection{EM SÍNTESE}

A análise dessas contradições põe em evidência valores, ideais e objetivos que permeiam as ações de itinerância de exposições científicas, trazendo à tona a urgência em discutir a organização e os pressupostos dessas atividades. Acrescentamos ainda a possibilidade que essas experiências proporcionaram aos participantes, permitindo a expansão de ciclos de aprendizagem, pois para se desenvolverem, os indivíduos têm que vivenciar a aprendizagem em situações empíricas.

Nessas relações, cria-se a base para internalização de saberes escolares, científicos, filosóficos e da vida (VYGOTSKY, 2010). De acordo com autor, o conhecimento que não passa pela vivência real do indivíduo não pode ser internalizado, constituindo-se somente como reprodução de informações.

Como evidenciamos no decorrer desta análise, as contradições gestadas no processo de significação do Túnel da Ciência no contexto brasileiro funcionaram tanto como obstáculos para desenvolvimento dessa articulação, como motores para a expansão de ciclos de aprendizagem, constituindo-se também como lentes para compreensão das questões histórico-culturais envolvidas no processo desta pesquisa. Nesta seção, foram apresentadas as contradições que emergiram dos 
encontros entre as diferentes historicidades dos participantes da pesquisa e de sua inserção em um novo tipo de ambiente de interação.

Resumidamente, as contradições percebidas/construídas por esta investigação foram:

a) As Ciências enquanto detentoras de características locais e sua relação com uma exposição itinerante que possui marcas de uma Ciência global.

b) $O$ financiamento das atividades culturais a partir de recursos públicos e necessidade de suprir tais demandas a partir da parceria com entidades privadas.

c) O uso das exposições científicas que passam pela exploração para a divulgação institucional e a necessidade de divulgação das ciências e tecnologia para o público visitante.

d) Os diferentes objetivos evolvidos nas visitações que passam pela aprendizagem de ciências por parte dos responsáveis e a interação com a exposição por parte das crianças.

e) A concepção de uma exposição que é marcada por valores universais em relação à significação de seu discurso versus a necessidade de modelos dialógicos que incorporem realidades locais.

f) $O$ processo de efetivação da internacionalização de uma exposição científica envolvida em uma série de negociações e a necessidade de efetivação daquilo que foi planejado.

g) A necessidade da formalização institucional da concepção de divulgação científica do MCTIC a fim de minimizar os impactos provenientes da instabilidade política.

h) A necessidade da teoria no processo formativo dos monitores e a inviabilidade de uma formação mais completa, em uma visão de apartamento entre teoria e prática.

i) O trabalho dos monitores que passa pela priorização do atendimento junto ao público escolar em detrimento da atuação junto ao público espontâneo.

j) A exploração da interatividade em sua multiplicidade de significados como um recurso midiático para divulgação da exposição que convive com a realidade efetiva e conflituosa da interação do púbico com tais elementos.

Essas contradições, juntamente com as contradições que emergem do processo de desenvolvimento do pesquisador responsável por esta pesquisa, consistem em um processo de significação da experiência do contexto analisado e 
contribuem para os apontamentos aqui realizados na área da pesquisa. 


\section{CAPÍTULO 6. CONSIDERAÇÕES FINAIS}

Conforme apresentado ao longo do texto, o estudo do movimento em prol da itinerância de uma exposição internacional não pode ser encarado como o acoplamento de diferentes instituições em busca de objetivos comuns, mas deve ser analisado por meio de uma visão que considere as relações orgânicas entre atividades com objetos distintos e multifacetados. A questão é complexa e a reflexão sobre os contextos presentes pode representar um caminho para a implementação de mudanças. Guiando as considerações finais, citamos duas frases que encarnam os objetivos dessa pesquisa: "Somente em movimento o corpo mostra o que é" (VYGOTSKY, 1997, p. 43) e "Na colisão, o novo, o estágio avançado de desenvolvimento aparece" (VYGOTSKY, 1997, p. 152). Tais citações relacionam-se fortemente ao objetivo dessa tese de compreender as negociações e tensões estabelecidas entre diferentes sujeitos envolvidos na significação de uma exposição científica de caráter internacional sob a ótica da perspectiva histórico-cultural.

A investigação centrou-se no processo de viabilização do Túnel da Ciência no Brasil, tendo o conceito de atividade como sua unidade de análise. O processo analítico foi feito a partir de dois níveis da estrutura da atividade: o das ações, ao olhar as ocorridas no ciclo de aprendizagem expansiva, e o da atividade, ao olhar as transformações das atividades a partir da superação das contradições. Nesse caminho, uma das opções de análise foi criar um quadro dos conteúdos que estão ligadas às contradições, compreendendo que essa análise pode ser uma contribuição para um maior entendimento do funcionamento das atividades sistêmicas.

$\mathrm{Na}$ discussão, evidenciamos que, apesar do tempo curto da exposição, diversas tensões e contradições puderam emergir e, em alguns casos, novas sínteses puderam ser produzidas a partir da atividade prática dos participantes da pesquisa. Tal discussão foi facilitada pelo mapeamento das atividades Central e periféricas. Além disso, estabelecemos relações entre o sistema de atividade dos monitores, dos visitantes, do representante da Produtora Geração, do MCTIC e do Max Planck. Vemos que, em última instância, todas as atividades interferem nas regras do sistema de atividade de monitoria, gerando tensões que tentam ser superadas ao longo do processo.

Em relação à Atividade de visitação, entendemos que é possível identificar 
mais de uma atividade e que isso cria tensões que precisam ser superadas por todos os participantes da pesquisa, em vista de se atingir o resultado esperado da atividade central, que é a promoção da cultura científica.

Quando analisamos e comparamos as atividades do MCTIC e do Instituto Max Planck, identificamos que as duas estão ligadas por tensões acumuladas ao longo dos quatro anos de negociações, o que, de certa forma, impede que a atividade do MCTIC seja reconhecida como essencial para a vinda da exposição ao Brasil.

Devemos entender os sistemas de atividades como dinâmicos e, portanto, é importante salientar que sistemas de atividade envolvem grandes ciclos históricos nos quais dificilmente é possível precisar o início ou o fim. Mesmo assim, o recorte realizado no trabalho tentou buscar a historicidade como forma de entender 0 conteúdo das contradições e as formas de superação. Esse entendimento é essencial para se gerar contribuições para futuros processos de vinda de exposições científicas internacionais ao Brasil.

A partir da análise dos dados e das categorias conceituais relativas às contradições, buscamos refletir sobre os núcleos de tensões presentes nos sistemas de atividades e entre eles, para a partir desses cenários buscar as conteúdos das contradições envolvidas no processo de internacionalização da exposição, garantindo uma ferramenta analítica que refletisse as categorias conceituais já presentes na Teoria da Atividade (ENGESTRÖN; SANINO, 2011).

Apresentamos, entre os resultados, os núcleos das tensões que se concentram nas seguintes questões: i) pressupostos envolvidos nos sistemas de atividade, ii) motivos explicitados pelos participantes, iii) características da exposição, iv) processos de gestão e v) monitoria realizada pelos educadores. Entendemos que explorar um quadro de contradições nucleadas nessas tensões era uma forma de compreender as mudanças que foram operadas durante o período de observação. As contradições assumiram, então, uma posição de destaque na pesquisa, superando uma visão metafísica de incoerência. A contradição, aqui, foi apresentada como real motor do desenvolvimento, sendo sua superação não apenas o conserto de erros lógicos mas a proposição de algo que supere os obstáculos que limitam a expansão da aprendizagem. Assim, pudemos identificar dez categorias que refletem os conteúdos das contradições de um processo de itinerância de uma exposição científica e internacional. São elas: Ciência local $x$ 
Ciência global, financiamento público $\mathrm{x}$ privado, aprender Ciências $\mathrm{x}$ compreender $\mathrm{O}$ mundo, divulgação institucional $x$ divulgação das ciências, modelos dialógicos $x$ valores universais, interatividade: discurso midiático $\mathrm{x}$ discurso expositivo, negociações entre o planejado $x$ efetivado, formalização institucional da concepção de $D C$ x instabilidade política, teoria $\mathrm{x}$ prática de monitoria, monitoria junto ao público escolar $\mathrm{x}$ mediação junto ao público espontâneo. Tal quadro categorial subsidia uma das intenções desta pesquisa: contribuir para o refinamento do referencial teóricometodológico de análise de contradições.

O método dialético, presente na perspectiva histórico cultural e na Teoria da Atividade, foi um importante suporte nesse processo, sendo compreendido como uma maneira de entender o escopo de mudanças e interações que ocorrem no contexto da atividade humana. Assim, se almejamos transformações na forma como os diversos setores da sociedade percebem e dialogam com as Ciências e Tecnologias, a dialética nos ajuda a refletir e buscar questões que possibilitam uma ação efetiva, fazendo-nos refletir sobre as mudanças que estão ocorrendo, as perspectivas futuras e a compreensão das relações que são estabelecidas entre as atividades humanas.

Após a conclusão deste momento da pesquisa, podemos ter uma visão melhor do cenário em que ocorreu a vinda do Túnel da Ciência ao Brasil, identificando que o grupo participante enfrentou uma situação diversamente conflituosa, na qual havia a necessidade de soluções urgentes. Nesse contexto, buscava-se sanar as dificuldades de viabilização das questões que envolvem a itinerância de uma exposição internacional, por meio de soluções individuais e coletivas.

Acreditamos que esta pesquisa não se encerra aqui, sendo um começo para a exploração do quadro de contradições apresentadas, buscando sua relação com outros contextos. Assim, assumimos que há pontos a serem explorados no futuro, como o cenário de engajamento dos monitores da exposição, que agem em um curto espaço de tempo, em uma intensa imersão, operarando mudanças em suas atividades. Tal análise pode ser realizada trazendo o aporte teórico relacionado à ideia de agency (agência), explorando a historicidade do trabalho do monitor que assume funções determinadas em contextos específicos na realidade brasileira.

Buscamos por meio da relação dessa pesquisa com outras da área, fornecer suporte para uma atividade de resistência perante os ataques de diversos setores da 
sociedade contra o desenvolvimento da Ciência e Tecnologia. Mais do que isso, buscou-se enfatizar a necessidade de mudanças na forma como a Ciência é apresentada, negando suas influências sociais, históricas e políticas, suas questões de gênero e suas especificidades locais. Denuncia-se, assim, com esse trabalho, o desmonte da proposta de construção de uma política de popularização da Ciência com o sucateamento do MCTIC, criando um cenário em que o diálogo entre a Ciência brasileira e os brasileiros fica dificultado.

Aponto, como inspiração, o trabalho dos monitores dessa exposição que afirmam, em suas práticas, a necessidade da subversão, de forma que possamos mostrar que temos uma cultura científica, com suas especificidades locais e que temos uma população que confere importância às Ciências. Esperamos, por fim, novas pesquisas que dialoguem com as elaborações mais recentes da Teoria da Atividade, para que se possa subsidiar um aparato teórico-metodológico eficiente para a identificação e interpretação das contradições presentes na atividade humana relacionadas à divulgação científica. 


\section{REFERÊNCIAS}

ALVES-MAZZOTTI, A. J.; GEWANDSZNADJER, F. O método nas ciências naturais e sociais: pesquisa quantitativa e qualitativa. São Paulo: Pioneira, 1998.

ASBAHR, F. S. F. A Pesquisa sobre atividade pedagógica: contribuições da teoria da atividade. Revista Brasileira de Educação. n. 29. Rio de Janeiro, 2005. p.108-118.

BACZKO. B. Imaginação social. In: Enciclopédia Einaudi. Antropos-Homem. Lisboa: Imprensa Nacional, Casa da Moeda, 1985

BANNON, L. Activity Theory. University of Limerick: Limerick, Ireland, 1997. Disponível em: http://wwwsv.cict.fr/cotcos/pjs/TheoreticalApproaches/Actvity/ActivitypaperBannon.h tm. Acesso em 03 fev. 2014.

BATESON, G. Steps to an Ecology of Mind. Ballantine Books. New York, NY, 1972.

Barbuy, H. O Brasil vai a Paris em 1889: um lugar na Exposição Universal. Anais do Museu Paulista. São Paulo, v. 4. 1996. p. 211-261.

BARROS, H. G. de P. L. de. Quatro Cantos de Origem. In Perspicillum. Museu de Astronomia e Ciências Afins. Vol. 6, № 1, novembro, 1992.

BAUMGARTEN, M. O debate público de ciência e tecnologia: divulgação, difusão e popularização. In: KERBAUY, M. T. M.; ANDRADE, T. H. N. de.; HAYASHI, C. R. M. (Org.). Ciểncia, Tecnologia e Sociedade no Brasil. Campinas: Editora Alínea, 2012. v. 1, p. 85-96.

BILLIG, M.; et al. Ideological Dilemmas: A Social Psychology of Everyday Thinking. Sage, London. 1988.

BIZERRA, A. Atividade de aprendizagem em museus de ciências. 2009. 274fls. Tese (Doutorado em Educação) - Faculdade de Educação, Universidade de São Paulo, São Paulo, 2009.

BLISMAS, N.; DAINTY, A. Computer-aided qualitative data analysis: panacea or paradox? Building Research \& Information, v. 31, n. 6, p. 455-463, 2003.

BOGDAN, R.; BIKLEN, S. Características da investigação qualitativa. In: Investigação qualitativa em educação: uma introdução à teoria e aos métodos. Porto: Porto Editora, 1994. p. 47- 51.

BUCCHI, M. Of Deficits, Deviations and Dialogues. Theories of Public Communication of Science. In BUCCHI, M.; TRENCH, B. (Eds.). Handbook of Public Communication and Science and Technology, $1^{\underline{a}}$ ed. London: Routledge, 2008. p. 57-76.

CARDENAL, E. Cántico cósmico. Managua: Nueva Nicaragua, 1989. 
CARLÉTTI, Chrystian; MASSARANI, Luisa. Mediadores de centros e museus de ciência: um estudo sobre quem são estes atores-chave na mediação entre a ciência e o público no Brasil. Journal of Science Communication, v. 14, n. 2, p. 1-17, 2015.

CAZELLI, S., MARANDINO, M., STUDART, D. Educação e Comunicação em Museus de Ciências: aspectos históricos, pesquisa e prática In: Educação e Museu: a construção social do caráter educativo dos museus de ciências ed. Rio de Janeiro: Editora Access, 2003. p. 83-106.

CATERALL, M. Using computer programs to code qualitative data. Marketing Intelligence and Planning, v. 14, n. 4, p. 29-33, 1996.

CENCI, A.; DAMIANI, M. F. Desenvolvimento da Teoria Histórico-Cultural da Atividade em três gerações: Vygotsky, Leontiev e Engeström. Revista Roteiro v.43, n.3. Joaçaba: UNOESC, 2018.

CENTRO DE GESTÃo E ESTUdOS ESTRATÉGICOS (CGEE). Percepção Pública da C\&T no Brasil 2015. Brasília, 2015. Disponível em: http://percepcaocti.cgee.org.br/ Acesso em: 20/02/2017.

CERQUEIRA, B. R. S. de; GENOVA, J. G.; BIZERRA, A. F. Ciência, Tecnologia e Sociedade em uma exposição científica internacional: o "Túnel da Ciência 3.0" no Brasil. Revista da SBEnBio, v. 7, 2014. p. 992 - 1003.

COBB, P.; et al. Design experiments in educational research. Educational Researcher, 32(1), 2003, p. $9-13$.

COLLINS, A.; JOSEPH, D.; BIELACZYC, K.. Design research: Theoretical and methodological issues. Journal of the Learning Sciences, 13(1), 2004, p. 15-42.

CRAWFORD, E.; SHINN, T.; SÖRLIN, S. The nationalization and desnationalization of the sciences: an introductory essay. In:

(Ed). Denationalizing science: the contexts of international scientific practice. Dordrecht: Kluwer, 1993. p. 1-42.

DANIELS, H. Vygotsky e a Pedagogia. São Paulo: Edições Loyola, 2003.

. Vygotsky e a pesquisa. São Paulo: Edições Loyola, 2011.

DENZIN, N. The research act: a theoretical introduction to sociological methods. 2 ed. New York: Mc Graw-Hill, 1978.

DENZIN, N. K.; LINCOLN, Y.S. Introduction: The Discipline and Practice of Qualitative Research. In: Sage: Thousand Oaks, 2005. p. 1-32.

DÍAZ, J. V. Divulgacion Científica y Democracia. In: Alambique - didáctica de las Ciencias Experimentales. p. 17-25. № 21, Ano VI, julio, 1999. 
DREU, C. K. W.; VAN DE VLIERT, E. Introduction: using conflict in organizations. In: (Eds.), Using Conflict in Organizations, Sage: London, 1997. p. 9-22.

DUARTE, R. Entrevistas em pesquisas qualitativas. Educar, Curitiba, n. 24, p. 213-225, 2004.

DURANT, J. Deciding which stories to tell: the challenge of presenting contemporary biotechnology. In: Proceedings of a conference held at the Science Museum. Here and now: contemporary science and technology in museums and science centres. Londres, 1996, p. 235-249.

ENGESTRÖM, Y. \& SANNINO, A. Discursive manifestations of contradictions in organizational change efforts: A methodological framework. Journal of Organizational Change Management, n. 24, p. 368-387, 2011.

Engeström, Y. From teams to knots: Activity-theoretical studies of collaboration and learning at work. Cambridge: Cambridge University Press. 2008.

Expansive Learning at Work: toward an activity theoretical reconceptualization. Journal of Education and Work, v. 14, n. 1, p. 133-156, 2010.

Learning by Expanding: An Activity - Theoretical Approach to Developmental Research. Helsinki: Orienta-Konsultit Oy, 1987.

ENGESTRÖM, Y., MIETTINEN, R., PUNAMÄKI, R. (Eds.). Perspectives on activity theory. New York: Cambridge University Press, 1999.

FAYARD, P. La sorpresa da Copérnico: el conocimento gira alredor del público. In: Alambique - didáctica de las Ciencias Experimentales. p. 9-16. $\mathrm{N}^{\circ} 21$, Ano VI, julio, 1999.

FARMER, T.; et al. Developing and implementing a triangulation protocol for qualitative health research. Qualitative Health Research, v. 16, p. 337-394, 2006.

FERREIRA, J. R.. Popularização da ciência e as políticas públicas no Brasil (2003-2012). Rio de Janeiro, 2014. 185 f. Tese (Doutorado em Ciências Biológicas Biofísica) - Instituto de Biofísica Carlos Chagas Filho, Programa de Pós-Graduação em Ciências Biológicas - Biofísica. Universidade Federal do Rio de Janeiro. Rio de Janeiro, 2014.

GADOTTI, M. A dialética: concepção e método. in: Concepção Dialética da Educação. 7 ed. São Paulo: Cortez/Autores Associados, 1990. Pp. 15-38.

GIL, F. B. Museus de ciência: preparação do futuro, memória do passado. Colóquio/Ciências: revista de Cultura Científica, Lisboa, n. 3, p. 78-89, 1988.

GÓES FILHO, P. de; ARAÚJO, F. B. Noções de ciência internacional e nacional: as trajetórias de Paulo Carneiro e Carlos Chagas Filho. In: Maio, M. C. (Org.) Ciência, política e relações internacionais: ensaios sobre Paulo Carneiro. Rio de Janeiro: Editora Fiocruz. p. 169-184. 2004. 
GOMES, I.; CAZELLI, S. Formação de Mediadores em Museus de Ciência: saberes e práticas. Ensaio Pesquisa em Educação em Ciências, Belo Horizonte, v. 18, n. 1, p. 23-46, 2016. Disponível em: http://dx.doi.org/10.1590/1983-21172016180102 . Acesso em 09/10/2017.

GONZÁLEZ REY, F. L. A pesquisa e o tema da subjetividade em educação. In: Anais da 24a. Reunião Anual da ANPEd. Outubro 2001.

GONZÁLEZ REY, F. L.; SILVA, M. A. F. Pesquisa qualitativa e subjetividade: os processos de construção da informação. São Paulo: Cengage Learning, 2005.

GORENGER, J.: O nascimento do materialismo histórico. In: MARX, K.\& ENGELS,F. A ideologia alemã. São Paulo: Martins Fontes, 1998. p. VII-XL.

GOUVÊA de Sousa, G. A Divulgação Científica para Crianças: o caso da Ciência Hoje das Crianças. Tese de Doutorado, CCS/UFRJ, agosto, 2000.

GRASS, I. B. P. o método nas pesquisas educacionais: uma aproximação metodológica ao estudo do desenvolvimento cultural. In: A Questão do método e a teoria histórico-cultural : bases teóricas e implicações pedagógicas.

MENDONÇA, S. G. L.; PENITENTE, L. A. A.; MILLER, S. (Org.). - Marília : Oficina Universitária ; São Paulo : Cultura Acadêmica, 2017. p. 39-61.

GRIMSHAW, J. Argument structure. Cambridge, MA: MIT Press. 1990.

GUION, L. A. Triangulation: establishing the validity of qualitative studies. Gainesville: University of Florida, 2002.

HOADLEY, C. Methodological alignment in design-based research. Educational Psychologist, 39(4), Educational design research in the 21st century. 2004. p. 203-212.

HOUSE OF LORDS. Science and Society. Third Report. London: House of Lords: Select Committee on Science and Technology, 2000.

IRWIN, A. Risk, Science and Public Communication. Third-Order Thinking About Scientific Culture. In BUCCHI, M.; TRENCH, B. (Eds.). Handbook of Public Communication and Science and Technology, $1^{\text {a }}$ ed. London: Routledge, 2008. p. 199-212.

KENJI, Allan. Em termos de educação pública nunca experimentamos um inimigo com uma força social tão concentrada como esse. Entrevista concedida à Andre Antunes em 27/04/2018, às 8h54min.. Atualizada em 11/05/5018. Disponível em: http://www.epsjv.fiocruz.br/noticias/entrevista/em-termos-de-educacao-publica-nuncaexperimentamos-uminimigo-com-uma-forca. Acesso em 20/06/2018.

KIRSCHBAUM, C. Decisões entre pesquisas quali e quanti sob a perspectiva de mecanismos causais. Revista Brasileira de Ciências Sociais, v. 28, n. 82, 2013.

KNORR-CETINA, K. Epistemic cultures: how the sciences make knowledge. 
Cambridge: Harvard University Press. 1999.

KONDER, L. O que é Dialética.São Paulo: Editora Brasiliense, 1989.

KOZULIN, A. The concept of activity in soviet psychology - Vygotsky, his disciples and critics. American Psychologist, Washington, v. 41. n. 3, p. 264-274. 1986.

KUHLMANN JÚNIOR, M. As grandes festas didáticas: a educação brasileira e as exposições internacionais (1862-1922). Bragança: Editora da Universidade São Francisco, 2001.

KUUTTI, M. Activity Theory as a Potential Framework for Human-Computer Interaction Research. In: NARDI, S. (Ed.). Context and Consciousness: Activity Theory and Human-Computer Interaction. Cambridge: MIT Press, 1996, p. 17-44.

LATOUR, B. A ciência em ação: como seguir cientistas e engenheiros sociedade afora. São Paulo: Ed. Unesp. 2000.

LAW, J. O laboratório e suas redes. La science et sés reseaux, Paris, La Découverte, 2005. Disponível em: http://www.necso.ufrj.br/Trads/ . Acesso em: 20/10/2018.

LEE, R. E. \& WALLERSTEIN, I. Structures of knowledge. The Blackwell Companion to Sociology, p. 228-235, 2000.

LEFEBVRE, H. Lógica formal/lógica dialética. Tradução de Carlos Nelson Coutinho. Rio de Janeiro: Civilização Brasileira, 1975.

LEMOS, M.; PEREIRA-QUEROL, M. A.; ALMEIDA, I. M. de. The Historical-Cultural Activity Theory and its contributions to Education, Health and Communication: interview with Yrjö Engeström. Interface-Comunicação, Saúde, Educação, v. 17, n. 46, p. 715-727, 2013. Disponível em: http://ref.scielo.org/p6tcry. Acesso em: 07/09/2018.

LEONTIEV, A. N. O desenvolvimento do psiquismo. Lisboa: Livros Horizonte, 1978.

Activity and Consciousness. Pacifica: Marxist Internet Archive, 2009.

2004.

O desenvolvimento do psiquismo. 2. ed. São Paulo: Centauro Editora,

The problem in Activity in Psychology. In: WERTSCH, J. V. The Concept of Activity in Soviet Psychology: An Introduction. M.E. Sharpe, Inc. New York: USA, 1980. p. 37-71.

LEWENSTEIN, B. V. Models of Public Communication of Science and Technology. Departments of Communication and of Science \& Technology Studies: Cornell University, 2003. 
LIBERALI, F. C.. Atividade social nas aulas de língua estrangeira. São Paulo: Moderna, v. 1, 2009.

LITOWITZ, B. E. Just say no: responsibility and resistance. In: Cole, M., ENGESTROM, Y.; VASQUEZ, O. (Eds), Mind, Culture, and Activity: Seminal Papers from the Laboratory of Comparative Human Cognition. Cambridge University Press, Cambridge. 1997.

LOUREIRO, J. M. M. Representação e museu científico: o instrutivo aparelho de hegemonia. Rio de Janeiro: tese de doutorado, Instituto Brasileiro de Informação em Ciência e Tecnologia, Escola de Comunicação, Universidade Federal do Rio de Janeiro, 2000.

LOUREIRO, J. M. M. Museu de ciência, educação científica e hegemonia. Ciência da Informação. Brasília, v. 32, n. 1, 2003. Disponível em: http://www.scielo.br/pdf/ci/v32n1/15976.pdf . Acesso em: 20 ago 2015.

Representação e museu científico: o instrutivo aparelho de hegemonia. Rio de Janeiro, 2000. 189 p. Tese (Doutorado)-Instituto Brasileiro de Informação em Ciência e Tecnologia, Escola de Comunicação, Universidade Federal do Rio de Janeiro.

LÖWY, I. Universalidade da ciência e conhecimentos situados. Cadernos Pagu, Campinas, n.15, p.15-38, 2000.

LUCCI, M. A. A proposta de Vygotsky: a psicologia sócio-histórica. Profesorado. Revista de currículum y formación del profesorado, 10(2), p. 1-11, 2006. Disponível em: http://www.ugr.es/ recfpro/rev102COL2port.pdf. Acesso em 06/09/2018.

LÜDKE, M.; ANDRÉ, M. E. D. A. Pesquisa em educação: abordagens qualitativas. São Paulo: EPU, 1986.

MAO TSÉTUNG. A Filosofia de Mao Tsétung. Belém: Boitempo, 1979.

MARTINS, L. M. As aparências enganam: divergências entre o materialismo histórico dialético e as abordagens qualitativas de pesquisa. Reunião anual da ANPED, v. 29, p. 1-17, 2006.

MINAYO, M. C. S. O desafio do conhecimento: pesquisa qualitativa em saúde. 7 . ed. São Paulo: Hucitec; Rio de Janeiro: Abrasco, 2000.

MITCHELL, R. E., The use of content analysis for exploratory studies. Publication SRC. No. A68. Survey Research Center, University of California, Berkeley. 1967

MORAES, R. Uma tempestade de luz: a compreensão possibilitada pela análise textual discursiva. Ciência \& Educação: Bauru, SP, v. 9, n. 2, p. 191-210, 2003. Disponível em: http://dx.doi.org/10.1590/S1516-73132003000200004 Acesso: 20/02/2017. 
MORAES, R; GALIAZZI, M. C. Análise textual discursiva: processo construído de múltiplas faces. Ciência \& Educação, v.12, n.1, p.117-128, 2006

MOREIRA, I. de C.; MASSARANI, L. Aspectos históricos da divulgação científica no Brasil. In: MASSARANI, L., MOREIRA, I. de C. e BRITO, F. Ciência e público: caminhos da divulgação científica no Brasil. Rio de Janeiro: Casa da Ciência Centro Cultural de Ciência e Tecnologia a UFRJ. Fórum de Ciência e Cultura, 2002, p. 43-64.

Divulgacíon de la ciencia: perspectivas históricas y dilemas permanentes, Quark, n.32, pp.30-35, 2004.

MOURA, E. A. As exposições científicas hands-on science como Fenômenos de público no brasil e suas estratégias de divulgação. Foro lbero-americano de comunicação e divulgação científica; 2009; Campinas. Disponível em:

https://www.oei.es/historico/forocampinas/PDF ACTAS/COMUNICACIONES/grupo5/ 073.pdf Acesso em: 20/04/2015.

NAVAS, A. M., MARANDINO, M. La popularización de la ciencia y la tecnología en América Latina. El caso de Brasil. Ciencias - revista de difusión de la facultad de ciencias de la UNAM. v.96, p.52 - 60, 2009.

NEVES, M. de S. As vitrines do progresso. O Brasil nas exposições internacionais. Rio de Janeiro: PUCRio / CNPq / Finep, 1986.

NEVES, M. de S. Uma arena pacífica. In: MAST. Imagens do progresso: os instrumentos científicos e as grandes exposições. Rio de Janeiro: MAST, 2001, p.2$8 . \quad$ Disponível em: http://www.mast.br/images/pdf/publicacoes do mast/catalogo exposicao imagem do progr esso.pdf Acesso em: 20/04/2017

OLIVEIRA, L. T. de; CARVALHO, A. Public Engagement with Science and Technology: contributos para a definição do conceito e a análise da sua aplicação no contexto português. Observatorio (OBS*), v. 9, n. 3, p. 155-178, 2015

PESAVENTO, S. J. Exposições Universais: Espetáculos da Modernidade do Século XIX. São Paulo: Hucitec, 1997

PONTE, J. P. da. $O$ estudo de caso na investigação em educação matemática. Revista Quadrante, v. 3, n. 1, 1994.

PRADO JÚNIOR, C. Dialética do Conhecimento: história da dialética/lógica dialética. São Paulo: Brasiliense, 1963.

REGO, T. C. Vygotsky: uma perspectiva histórico-cultural da educação. Petrópolis: Vozes, 2004.

ROCHA. J. N. Museus e centros de ciências itinerantes: análise das exposições na perspectivada Alfabetização Científica São Paulo. 638f. Tese (doutorado).Pós- 
Graduação em Educação - Faculdade de Educação, 2018. (p. 127 a 147)

RODRIGUES, A. M. Movimento e contradição: a disciplina de práticas em ensino de Física e a formação inicial de professores de Física sob uma perspectiva histórico-cultural.. 276 f. Tese (Doutorado) - Ensino de Ciências, Universidade de São Paulo, São Paulo, 2009.

ROGERS, Y.; SCAIFE, M. Activity Theory.1997. Disponível em: http://wwwsv.cict.fr/cotcos/pjs/TheoreticalApproaches/Actvity/ActivitypaperRogers.ht m. Acesso em 05/02/2014.

ROGOFF, B. Observing sociocultural activity on three planes: Participatory appropriation, guided participation, and apprenticeship. In: WERTSCH, J. V.; P. DEL RIO, P.; ALVAREZ, A. (Orgs.), Sociocultural studies of mind. Cambridge, UK: Cambridge: Universtity Press, 1995, p. 139-163.

ROSS, E. W.; G., M.. Pensando de manera crítica sobre el pensamiento crítico. Aula abierta, vol. 47, no 4; p. 383-386, 2018. Disponível em: http://redined.mecd.gob.es/xmlui/handle/11162/174910 Acesso em: 10/12/2018.

RUBINSTEIN, S. L. El desarrollo de la psicología: principios y métodos. Ciudad de La Habana: Rene Meneses, 1978.

RUFATO, B. Diferenças entre mães e pais em visita a museus de ciências. 2015. 130f.Dissertação (Mestrado em ensino de Ciências) - Faculdade de Educação, Instituto de Física, Instituto de Química e Instituto de Biociências, Universidade de São Paulo, São Paulo. 2015.

SANNINO, A. Experiencing conversations: bridging the gap between discourse and activity, Journal for the Theory of Social Behaviour, Vol. 38 No. 3, pp. 267-91, 2008.

SANTOS, M. S. Banalização da arte ou democratização da cultura? Uma investigação sobre o uso de novas tecnologias de informação por exposições de caráter transnacional. In: xxv Encontro Aanual da ANPOCS, 2001, Caxambu. ANPOCS, p. 112-113, 2001.

SANTOS, Myrian Sepúlveda. AS MEGAEXPOSIÇÕES NO BRASIL: DEMOCRATIZAÇÃO OU BANALIZAÇÃO DA ARTE?. Cadernos de Sociomuseologia, [S.I.], v. 19, n. 19, 2009. Disponível em: $<$ http://revistas.ulusofona.pt/index.php/cadernosociomuseologia/article/view/368>.

Acesso em: 01 jan. 2019.

SANTOS, P. C. dos. Um olhar sobre as exposições universais. In: SIMPÓSIO NACIONAL DE HISTÓRIA, Anais... Natal, 2013. Disponível em: http://www.snh2013.anpuh.org/resources/anais/27/1362520918 ARQUIVO CesarA NPUH1.pdf . Acesso em: 15 jun 2016.

SARAIVA, E.; PENTEADO, J. R. W. Megaexposições de arte no Rio de Janeiro: aspectos de marketing. Em manutenção, v.6, n.5, p. 28-33, 2008. 
SCIENCE TUNNEL MAX PLANCK. Banco de imagens. Disponível em: https://www.sciencetunnel.de/images . Acesso em: 20/03/2017

SLUZKI, C., RANSOM, D. Double Bind the Foundation of the Communicational Approach to the Family. Londres: Grune \& Stratton, 1976.

SOUZA, D. M. V. de. Museus de ciência, divulgação científica e informação: reflexões acerca de ideologia e memória. Perspectivas em Ciência da Informação, v. 14, n. 2, p. 155-168, 2009.

SOUZA, L. Pumar Alves de. Por uma ciência universal: a atuação de intelectuais brasileiros no projeto de cooperação intelectual da Liga das Nações (décadas de 1920 a 1940). Simpósio Nacional de História - Anpuh, 26., jul. 2011, São Paulo. Anais... São Paulo: Associação Nacional dos Professores Universitários de História. p.1-15. Disponível em: http://www.snh2011.anpuh.org/ resources/anais/14/1300803039_ARQUIVO_TextoANPUH-2011.pdf. jul. Acesso em: 15 fev. 2015.

STAKE, R. E. Case studies. In: DENZIN, N. K.; LINCOLN, Y. S. (Eds.). Handbook of qualitative research. 2. ed. London: Sage, 2000. p. 435-454

STENGERS, I. A invenção das ciências modernas. São Paulo: Editora 34. 2002.

STETSENKO, Anna. Activity as object-related: Resolving the dichotomy of individual and collective planes of activity. Mind, Culture, and Activity, v. 12, n. 1, p. 70-88, 2005.

TEIXEIRA COELHO NETO, J. Dicionário Crítico de Política Cultural. São Paulo: lluminuras, 1997.

TRENCH, B. Towards an Analytical Framework of Science Communication Models. In CHENG, D.; et al.; Eds., Communicating Science in Social Contexts: New Models, New Practices: Springer Netherlands, 2008, p. 119-138.

TRIVIÑOS, A. N. da S. Introdução à pesquisa em ciências sociais: a pesquisa qualitativa em educação. São Paulo: Atlas, 2008.

TULESKI, S. C. Vygotsky: a construção de uma psicologia marxista. Maringá: Eduem, 2008.

VARINE-BOHAN, H. Entrevista com Hugues de Varine-Bohan. Os museus no mundo, Rio de Janeiro, p. 8-21, p. 70-81, 1979.

VALENTE, M. E.; CAZELLI, S.; ALVES, F. Museus, ciência e educação: novos desafios. História, ciências, saúde-Manguinhos, v. 12, p. 183-203, 2005.

VELOSO, Clarissa dos Santos, ANDRADE, Luciana Teixeira de Andrade. Museus Público-Privados e espetacularização da cultura: Limites e Tensões. Dossiê Capitalismo Cultural: Arquivos do CMD. Volume 4, n.2. Jul/Dez 2016. 
VIANA DE SOUZA, D. M. Divulgação Científica em Museus e Centros de Ciência Interativos: a construção social de uma ciência-espetáculo. Porto Alegre: UFRGS, 2016. 435 f. Tese (Doutorado em Sociologia) - Programa de PósGraduação em Sociologia, Instituto de Filosofia e Ciências Sociais, Universidade Federal do Rio Grande do Sul, Porto Alegre, 2016.

VIANNA, H. M. Pesquisa em educação: a observação. Brasília: Liber Editora, 2007.

VIGOTSKI, L. S. Psicologia pedagógica. São Paulo: Martins Fontes. 2001.

VYGOTSKY, L. S. Mind in society: The development of higher psychological processes. Cambridge, MA: Harvard university press, 1980.

Psicologia pedagógica. São Paulo: Martins Fontes, 2004.

Pensamento e linguagem. São Paulo: Editora Martins Fontes, 3aㅡ Ed., 2005. Tradução Jefferson Luiz Camargo.

WAITE, T. Activity Theory. 2003. Disponível em: <http://www.slis.indiana.edu/faculty/yrogers/act theory2>. Acesso em 01 fev. 2014.

WERTSCH, J. V. A Sociocultural approach to socially shared cognition. In: L. B. Resnick, J. M. Levine, \& S. D. Teasley (Orgs.). Perspectives on socially shared cognition. Washington, DC: American Psychological Association. 1991, p. 85-100.

WICKHAM, M.; WOODS, M. Reflecting on the Strategic Use of CAQDAS to Manage and Report on the Qualitative Research Process. The Qualitative Report, 10(4), p. 687-702, 2005

WILDE, A. Marx and Contradiction, Avebury, Aldershot, UK, 1989.

XAVIER, Denise. A museologia itinerante: uma perspectiva histórica. Cadernos de Sociomuseologia, [S.I.], n. 1, june 2014.. Disponível em: $<$ http://revistas.ulusofona.pt/index.php/cadernosociomuseologia/article/view/4515>. Acesso em: 10 dec. 2018.

YAMAGATA-LYNCH, Lisa C. Qualitative Research in Activity Systems Analysis. In:__ Activity Systems Analysis Methods. Springer: Boston, 2010, p. 63-79.

YIN, Robert K. - Case Study Research - Design and Methods. Sage Publications Inc., USA, 1989 


\section{APÊNDICES}

\section{APÊNDICE A - Termo de consentimento livre e esclarecido (maiores de 18 anos)}
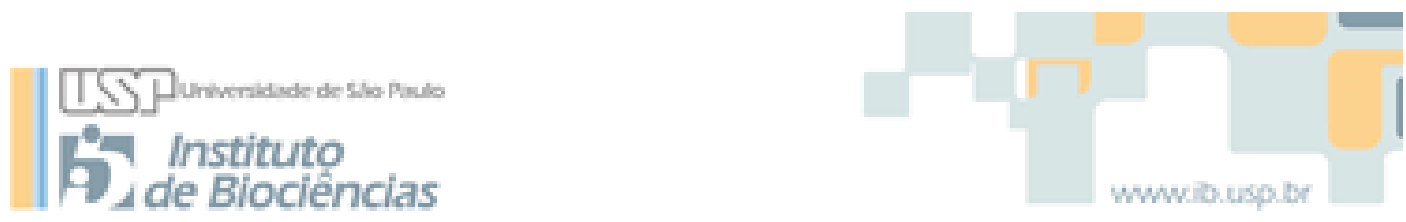

TERMO DE CONSENTIMENTO LIVRE E ESCLARECIDO

(Maiores de 18 anos)

ESTUDO: MANIFESTACCÖES DSCURSNAS DE CONTRADUÇD́ES: Análise de uma expasiçăo cientifica internadional no Brael pela perspectiva histórico-cultural

Vock estó sendo convidada(a) a participar do prajeto de pesquisa acima citado. Este documento contidm as infarmaçbes sobve a pesquisa que estamas farenda sua calaboraçbo nesse estudo será de muita impartáncla povo nós.

CPF $\longrightarrow$ nascido(a) em $\mathrm{em}$ concardo de liwre e espontânea em particlpar do estudo MANIFESTAÇÖES DISCURSIVAS DE CONTRADıçöEs: Ansilise de uma exposiçăo cientifica internacional no Brasl pela perspectiva histórico-cultural, e esclareço que obtive todas as informaçdes necessárias.

Estou ciente que:

1) O estuda se fax necessírio para fomecer subisidias pafa o entendi-ento das negociaçbes $e$ tensōes estabelecidas entre điferemes sujeitos envelvídos na significação de uma exposiç̧̄o cientifica de carbser internacional;

1) Como metodologia do estudo, serdo realizadas gravaçăo em áuclo e video das entrevistas;

ㅍil) A participaçato nessa pesquisa năa envolve riscos flakicas. No entanta, é passivel que haja algum constrangimenta quando da presença da filmadara e/ou da gravador de vaz:;

iv) Tenho a liberdade de desistir ou interromper a colaboraç̧o nesse estudo no momento em que desejar;

v) Os resultados obtidos durante essa pesquisa serdo mantidos em sigila, mas concordo que sejam divulgados em publicaçbes cientificas, desde que os dados pessoais que permitam a identificaçâo de meu(mirha) filho(a) năo sejam mencianados;

vi) Caso eu deseje, poderei tomar conhecimento das resultados, a final dessa pesquisa.

Desejo conhecer os resultadas dessa pesquika. E-mail:

Nâo desejo canhecer os resultados dessa pesquisa.

vil) Caso tenham sido tiradas fotografias:

- Concordo que sejam incluidas em publicaçōes cientificas ou apresentaçb̆es.

[. Concordo que sejam incluidas em publicaçbes cientificas ou apresentaçb̆es, se seu rosto nlio aparecer ou estiver desfocado;

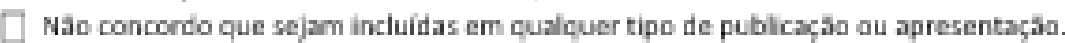




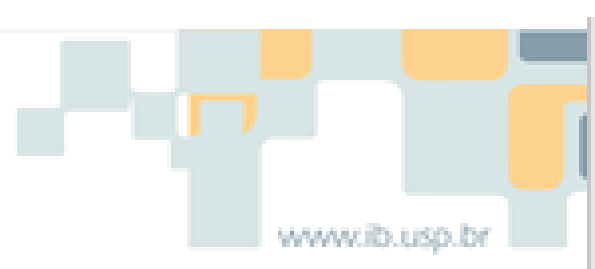

VIII) O material colhido será armazenado sob a responsabilidade do Instituto de Biaciências - USP e sab a guarda da(o) Alessandra Fernandes Bizerra, pelo tempo necessária para a análise dos dados e adequado mapeamento e caracterizaçalo dos resultados e de sua influênda para a área da pesquísa.

Sละ Paulo, de de 20

Assinatura do(a) Responsfivel pelo(a) Participante Bruno Rafael Santas de Cerqueira - Doutoranda da Pragrama de Pós-graduaçalo Interunidades em Ensino de Cèncias da USP;

Assinatura da Pesquisador Responeivel pelo Projeto Alessandra Fernandes Biserra - Docente do Instituto de Biociênclas da USP

No caso de haver dúvidas sobre aspectos éticos desse estudo, você poderá consultar:

Pesqulsador(a) Responstivel: Bruno Rafael Santos de Cerqueira

Endereço: Universidade de Sao Paulo, Instituta de Biaciéncias, Departamento de Zaolagia. Rua do Matilo, Laboratónio de Ensino de Biologia, Sala 153 - Butantä - CEP: DG508090 - S4o Paulo, SP - Brasil e-mail: cerqueirabrseusp.br

Telefane para cantato: (11) 30917575

Orientador(a): Alessandra Fernandes Bixerra

Endereça: Universidade de Säo Paulo, Instituta de Biaciências, Departamento de Zoolagia. Rua do Mațo, Laboratónio de Ensino de Biologja, Sala 153 - Butantá - CEP: DG508090 - Slo Paulo, SP - Brasi

email: kebizerraegmail.com

Telefane para cantato: (11) 30917575

\section{Para contato com o CEP-IB:}

Camitê de Ética em Pesquisa - Seres Humanos (CEP) do Instituta de Biodíncias da Universidade de Sto Paulo

Rua do Matâo - travessa 14, 321 - Cidade Uniwersitiria, CEP: 05508 090-Sâo Paulo - SP Telefane (11) 3091-8761 - e-mail: cepibuspeib.usp.br. 


\section{APÊNDICE B - Termo de consentimento livre e esclarecido (menores de 18 anos)}

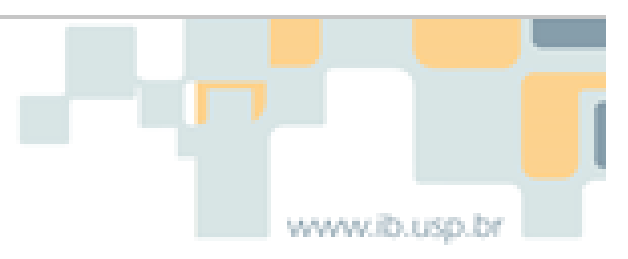

TERMO DE CONSENTIMENTO LUFE E ESCLARECIDO

[Menores de 18 anos!

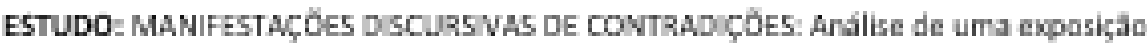
dentifin intemadonal no Bradil pela perspectiva histérico altural

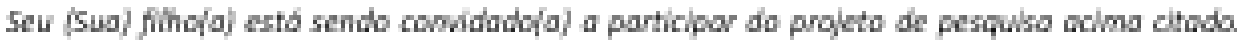

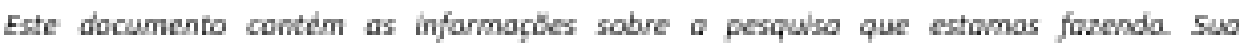
calaborapto nese cstudo sad de multo importancib povo nds.

Eu, 品 abato

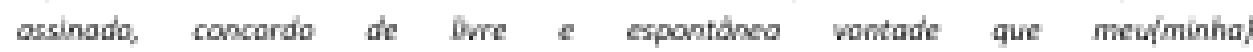
fithollol , nocidalo wh

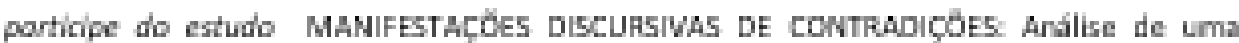

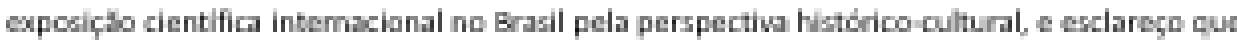
obtive todes in informacibs necoseliris.

Estcu dente ques

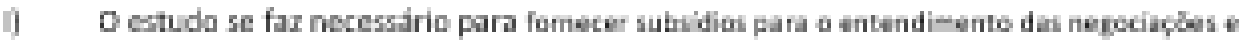

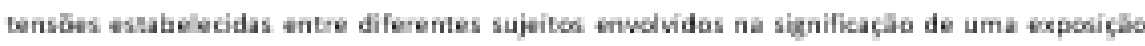

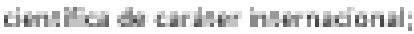

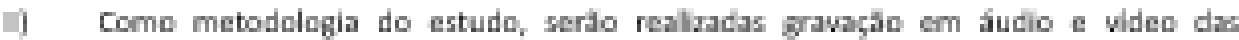
entrovistas:

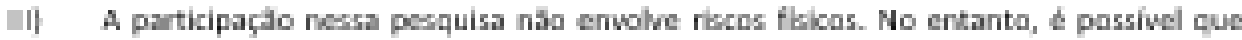
haja algum constrangimenta quando da presenga da filmadara glou da groudar de vor:

wh Tenho a liberdade de desistir ou intermomper a colbboracto nesse estudo no momento em que desejar;

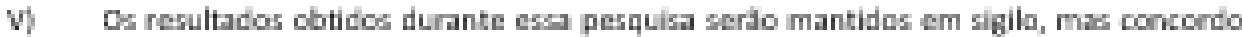
que sejam diulgador em publicades cientifics, desde que or dados pesaals que

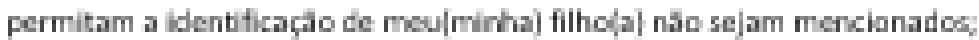

vi Gasou deseje, poderei tomar conhecimento das resultados, wo final desta pequiga.

1 Deseja conhecer os resultadas dossa pescubal Email:

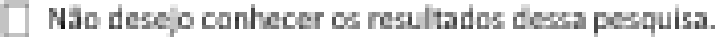

vil Gaso tenham sido tirodas fotografis:

Concondo que sejam hiduidas em publicxides cientifica ou apresentapes.

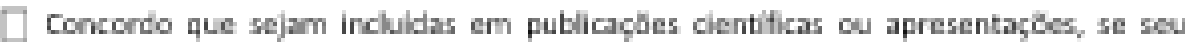
rooto nito aparecer au asther desfocado:

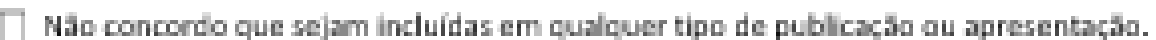


VII) Q material calhido seri armazenado sob a responsabilidade da Instituto de Biaciencizs

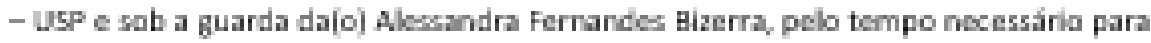
a análise dos dador e adequado mapeamento e caracterizpo dos resuliador e de sua influênda para a ânea da pesqubi.

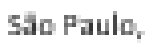
de de 20

Asshatura dodal Responsfiel pelcial Particponte

Assinatura da Pequlisador Respandivel pelo Projeto Bruno Fafbel Santas de Cerqueira - Doutoranda da Pragrama de Pós graduacto Interundades em Ensino de Denciar da USP.

\section{No caso de haver dúvidas sobre aspectos éticos desse estuda, voch poderf consultar:}

Pesqubadoriaj Responsthel: Bruna Rafad Santos de Cerqueira

Enderso: Universidade de S9o PaLlo, Inetituta de Biocidncias, Departamento de Zodogia.

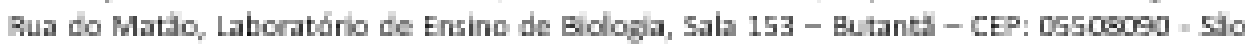
Pwib, SP - Bras email: cerquarabresuspr Telefone para cantato (11) 30917575

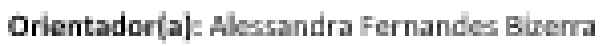

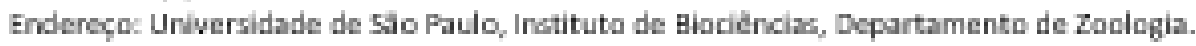

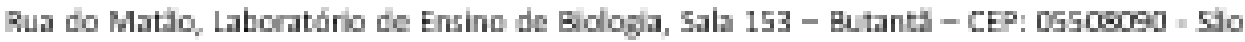
Puib, SF = Brasil email: kebizenatginail.com Telefone para contatos $(11) 30917575$

\section{Para contato com a CEP-IB:}

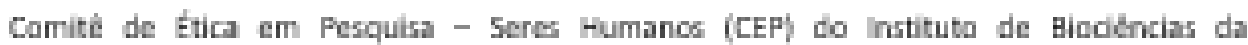
Unhersidade da Sta Pailo

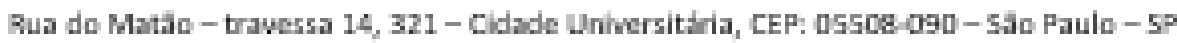
Telefane [11] 3a91-g751 - email: capibup bib.Lep.br. 
APÊNDICE C - Lista de exposições universais*

\begin{tabular}{|c|c|c|c|c|c|c|}
\hline Cidade & País & Ano & Tema & $\begin{array}{c}\text { Designação } \\
\text { oficial }\end{array}$ & $\begin{array}{l}\text { Número de } \\
\text { Visitantes }\end{array}$ & $\begin{array}{c}\text { Número } \\
\text { de Países } \\
\text { Participa } \\
\text { ntes }\end{array}$ \\
\hline Londres & Inglaterra & 1851 & $\begin{array}{l}\text { Indústria de } \\
\text { todas as } \\
\text { nações }\end{array}$ & $\begin{array}{l}\text { A grande } \\
\text { exposição das } \\
\text { obras de todas as } \\
\text { nações }\end{array}$ & 6.039 .195 & 25 \\
\hline Paris & França & 1855 & $\begin{array}{l}\text { Agricultura, } \\
\text { indústria e } \\
\text { artes } \\
\text { plásticas }\end{array}$ & $\begin{array}{l}\text { Exposição } \\
\text { Universal de } \\
\text { Produtos } \\
\text { Agrícolas, Indústria } \\
\text { e Belas Artes de } \\
\text { Paris } 1855\end{array}$ & 5.162 .330 & 27 \\
\hline Londres & Inglaterra & 1862 & $\begin{array}{l}\text { Indústria e } \\
\text { arte }\end{array}$ & $\begin{array}{l}\text { Exposição } \\
\text { Internacional de } \\
\text { Indústria e Arte de } \\
\text { Londres }\end{array}$ & 6.096 .617 & 39 \\
\hline Paris & França & 1867 & $\begin{array}{l}\text { Agricultura, } \\
\text { indústria e } \\
\text { artes } \\
\text { plásticas }\end{array}$ & $\begin{array}{l}\text { Exposição } \\
\text { Universal de Paris } \\
1867\end{array}$ & 15.000 .000 & 42 \\
\hline Viena & Áustria & 1873 & $\begin{array}{l}\text { Cultura e } \\
\text { Educação }\end{array}$ & $\begin{array}{l}\text { Exposição } \\
\text { Universal de Viena } \\
1873\end{array}$ & 7.255 .000 & 35 \\
\hline Filadélfia & $\begin{array}{l}\text { Estados } \\
\text { Unidos da } \\
\text { América }\end{array}$ & 1876 & $\begin{array}{l}\text { Belas Artes, } \\
\text { Indústria, } \\
\text { Produtos do } \\
\text { Solo e } \\
\text { Mineração }\end{array}$ & $\begin{array}{l}\text { Exposição } \\
\text { centenária de } \\
\text { artes, manufaturas } \\
\text { e produtos do solo } \\
\text { e da minha }\end{array}$ & 10.000 .000 & 35 \\
\hline Paris & França & 1878 & $\begin{array}{l}\text { Notícias } \\
\text { sobre } \\
\text { tecnologias }\end{array}$ & $\begin{array}{l}\text { Exposição } \\
\text { Universal de 1878, } \\
\text { Paris }\end{array}$ & 16.156 .626 & 35 \\
\hline Melbourne & Austrália & 1880 & $\begin{array}{l}\text { Arte, } \\
\text { Fabricação, } \\
\text { Produtos da } \\
\text { Agricultura e } \\
\text { Indústria de } \\
\text { todas as } \\
\text { Nações }\end{array}$ & $\begin{array}{l}\text { Exposição } \\
\text { Internacional de } \\
\text { Artes, } \\
\text { Manufacturas, } \\
\text { Produtos Agrícolas } \\
\text { e Industriais de } \\
\text { todas as Nações }\end{array}$ & 1.330 .000 & 33 \\
\hline Barcelona & Espanha & 1888 & $\begin{array}{l}\text { Belas Artes e } \\
\text { Artes } \\
\text { Industriais }\end{array}$ & $\begin{array}{l}\text { Exposição } \\
\text { Universal } \\
\text { Barcelona } 1888\end{array}$ & 2.300 .000 & 30 \\
\hline
\end{tabular}




\begin{tabular}{|c|c|c|c|c|c|c|}
\hline Paris & França & 1889 & $\begin{array}{l}\text { Comemoraçã } \\
\text { o do } \\
\text { centenário da } \\
\text { Revolução } \\
\text { Francesa }\end{array}$ & $\begin{array}{l}\text { Exposição } \\
\text { Universal de 1889, } \\
\text { Paris }\end{array}$ & 32.250 .297 & 35 \\
\hline Chicago & $\begin{array}{l}\text { Estados } \\
\text { Unidos da } \\
\text { América }\end{array}$ & 1893 & $\begin{array}{l}400^{\circ} \\
\text { aniversário } \\
\text { da } \\
\text { descoberta } \\
\text { da América }\end{array}$ & $\begin{array}{l}\text { Exposição } \\
\text { Universal } \\
\text { Colombiana }\end{array}$ & 27.500 .000 & 19 \\
\hline Bruxelas & Bélgica & 1897 & Vida Moderna & $\begin{array}{l}\text { Exposição } \\
\text { Internacional de } \\
\text { Bruxelas, } 1897\end{array}$ & 6.000 .000 & 27 \\
\hline Paris & França & 1900 & $\begin{array}{l}\text { O balanço de } \\
\text { um século }\end{array}$ & $\begin{array}{l}\text { A Exposição de } \\
\text { Paris } 1900\end{array}$ & 50.860 .801 & 40 \\
\hline St. Louis & $\begin{array}{l}\text { Estados } \\
\text { Unidos da } \\
\text { América }\end{array}$ & 1904 & \begin{tabular}{|l|} 
Da \\
celebração \\
do centenário \\
da compra da \\
Louisiana
\end{tabular} & \begin{tabular}{|l} 
Exposição \\
Universelle de \\
Saint-Louis 1904
\end{tabular} & 19.694 .855 & 60 \\
\hline Liége & Bélgica & 1905 & $\begin{array}{l}\text { Comemoraçã } \\
\text { o do } 75^{\circ} \\
\text { aniversário } \\
\text { da } \\
\text { independênci } \\
\text { a }\end{array}$ & $\begin{array}{l}\text { Exposição } \\
\text { Universal de Liège } \\
1905\end{array}$ & 7.000 .000 & 35 \\
\hline Milão & Itália & 1906 & Transporte & $\begin{array}{l}\text { Exposição } \\
\text { Universal de } 1906\end{array}$ & 10.000 .000 & 40 \\
\hline Bruxelas & Bélgica & 1910 & $\begin{array}{l}\text { Obras de } \\
\text { Arte, } \\
\text { Trabalhos } \\
\text { Científicos e } \\
\text { Produtos da } \\
\text { Indústria e } \\
\text { Agricultura de } \\
\text { todas as } \\
\text { Nações }\end{array}$ & $\begin{array}{l}\text { Exposição } \\
\text { Universal e } \\
\text { Internacional de } \\
\text { Bruxelas, } 1910\end{array}$ & 13.000 .000 & 26 \\
\hline Ghent & Bélgica & 1913 & $\begin{array}{l}\text { Paz, da } \\
\text { indústria e da } \\
\text { arte }\end{array}$ & $\begin{array}{l}\text { Exposição } \\
\text { Universal } \\
\text { Internacional, } \\
\text { Ghent } 1913\end{array}$ & 9.503 .419 & 24 \\
\hline $\begin{array}{l}\text { San } \\
\text { Francisco }\end{array}$ & $\begin{array}{l}\text { Estados } \\
\text { Unidos da } \\
\text { América }\end{array}$ & 1915 & $\begin{array}{l}\text { A } \\
\text { inauguração } \\
\text { do Canal do } \\
\text { Panamá }\end{array}$ & $\begin{array}{l}\text { Exposição } \\
\text { internacional } \\
\text { Panamá-Pacífico }\end{array}$ & 18.876 .438 & 24 \\
\hline Barcelona & Espanha & 1929 & $\begin{array}{l}\text { Indústria, Arte } \\
\text { e Esporte }\end{array}$ & $\begin{array}{l}\text { Exposição } \\
\text { Internacional de } \\
\text { Barcelona } 1929\end{array}$ & 5.800 .000 & 29 \\
\hline
\end{tabular}




\begin{tabular}{|c|c|c|c|c|c|c|}
\hline Chicago & $\begin{array}{l}\text { Estados } \\
\text { Unidos da } \\
\text { América }\end{array}$ & $\begin{array}{l}1933 \\
e \\
1934\end{array}$ & $\begin{array}{l}\text { Independênci } \\
\text { a entre } \\
\text { indústria e } \\
\text { pesquisa } \\
\text { científica }\end{array}$ & $\begin{array}{l}\text { Um século de } \\
\text { progresso, } \\
\text { Exposição } \\
\text { internacional, } \\
\text { 1933-34 }\end{array}$ & 38.872 .000 & 21 \\
\hline Bruxelas & Bélgica & 1935 & Transporte & $\begin{array}{l}\text { Exposição } \\
\text { Internacional de } \\
\text { Bruxelas, } 1935\end{array}$ & 20.000 .000 & 35 \\
\hline Paris & França & 1937 & $\begin{array}{l}\text { Artes e } \\
\text { técnicas na } \\
\text { vida moderna }\end{array}$ & $\begin{array}{l}\text { Exposição } \\
\text { internacional de } \\
\text { artes e técnicas na } \\
\text { vida moderna }\end{array}$ & 31.040 .955 & 45 \\
\hline Nova lorque & $\begin{array}{l}\text { Estados } \\
\text { Unidos da } \\
\text { América }\end{array}$ & $\begin{array}{l}1939- \\
1940\end{array}$ & $\begin{array}{l}\text { Construindo o } \\
\text { mundo do } \\
\text { amanhã }\end{array}$ & $\begin{array}{l}\text { Feira Mundial de } \\
\text { Nova lorque de } \\
1939-40\end{array}$ & 44.932 .978 & 54 \\
\hline $\begin{array}{l}\text { Porto } \\
\text { Príncipe }\end{array}$ & Haiti & 1949 & $\begin{array}{l}\text { O Festival da } \\
\text { Paz }\end{array}$ & $\begin{array}{l}\text { Exposição } \\
\text { internacional } \\
\text { bicentenária de } \\
\text { Porto Príncipe, } \\
\text { 1949-1950 }\end{array}$ & 250.000 & 15 \\
\hline Bruxelas & Bélgica & 1958 & $\begin{array}{l}\text { Equilíbrio por } \\
\text { um mundo } \\
\text { mais humano }\end{array}$ & $\begin{array}{l}\text { Exposição mundial } \\
\text { e internacional } \\
\text { Bruxelas, } 1958\end{array}$ & 41.454 .412 & 39 \\
\hline Seattle & $\begin{array}{l}\text { Estados } \\
\text { Unidos da } \\
\text { América }\end{array}$ & 1962 & $\begin{array}{l}\text { Homem na } \\
\text { era espacial }\end{array}$ & $\begin{array}{l}\text { Exposição do } \\
\text { século } 21\end{array}$ & 9.000 .000 & 49 \\
\hline Montreal & Canadá & 1967 & $\begin{array}{l}\text { O Homem e } \\
\text { seu Mundo }\end{array}$ & $\begin{array}{l}\text { Exposição mundial } \\
\text { e internacional } \\
\text { Montreal } 1967\end{array}$ & 50306648 & 62 \\
\hline Osaka & Japão & 1970 & $\begin{array}{l}\text { Progresso } \\
\text { Humano na } \\
\text { Harmonia }\end{array}$ & $\begin{array}{l}\text { Exposição } \\
\text { Universal e } \\
\text { Internacional } \\
\text { Japonesa Osaka } \\
1970\end{array}$ & 64.218 .770 & 78 \\
\hline Sevilha & Espanha & 1992 & $\begin{array}{l}\text { A era das } \\
\text { descobertas }\end{array}$ & $\begin{array}{l}\text { Exposição } \\
\text { Universal de } \\
\text { Sevilha }\end{array}$ & 41.814 .571 & $108^{*}$ \\
\hline Alemanha & Hanover & 2000 & $\begin{array}{l}\text { Homens - } \\
\text { Natureza - } \\
\text { Tecnologia }\end{array}$ & $\begin{array}{l}\text { Expo } 2000 \\
\text { Hannover }\end{array}$ & 18.100 .000 & $155^{*}$ \\
\hline Xangai & China & 2010 & $\begin{array}{l}\text { Melhor } \\
\text { cidade, vida } \\
\text { melhor }\end{array}$ & $\begin{array}{l}\text { Expo Shanghai } \\
2010\end{array}$ & 73.085 .000 & $246^{*}$ \\
\hline Milão & Itália & 2015 & $\begin{array}{l}\text { Alimentando } \\
\text { o planeta, } \\
\text { energia para } \\
\text { a vida }\end{array}$ & Expo Milão 2015 & 21.500 .000 & $145^{*}$ \\
\hline
\end{tabular}




\begin{tabular}{|l|l|l|l|l|l|l|}
\hline Dubai & $\begin{array}{l}\text { Emirados } \\
\text { Árabe } \\
\text { Unidos }\end{array}$ & 2020 & $\begin{array}{l}\text { Conectando } \\
\text { mentes, } \\
\text { construindo o } \\
\text { futuro }\end{array}$ & - & $\begin{array}{l}25.000 .000 \\
\text { (previsto) }\end{array}$ & - \\
\hline
\end{tabular}

* Informações extraídas do site oficial das exposições universais: https://www.bieparis.org/site/en.

APÊNDICE D - Roteiro de entrevista semiestruturada - Representante do Instituto Max Planck

\section{Formação profissional}

1) O Sr. é formado em Filosofia. Como se deu sua escolha profissional?

2) Como foi sua entrada no Instituto Max Planck? E sua relação com a DC?

3) Quais são suas atividades diárias no Instituto?

\section{Concepção de Divulgação Científica e de Ciência}

4) Se considerarmos a perspectiva Kuhniana de ciência normal e paradigmática, como o Sr. classificaria a pesquisa desenvolvida no IMP?

5) $\mathrm{Na}$ palestra de ontem, foi dito que o IMP está voltado para a pesquisa básica. $O$ Sr. define essa pesquisa como uma ciência universal? Haveria uma distinção entre universal, regional e local?

4) Em sua experiência, quais deveriam ser os objetivos da DC? É coerente com a visão institucional?

7) Ontem ainda foi colocada a importância de sairmos de um modelo de déficit na DC para um modelo mais dialógico. Quais os elementos da exposição que a tornam mais dialógica?

8) A exposição já visitou mais de vinte países. Em algum deles teve maiores adaptações que atendessem às especificidades da cultura regional do país visitado? Quais foram as adaptações?

\section{Objetivos e expectativas da Exposição no Brasil e Mundo}

9) Quais são os objetivos da Sociedade Max Planck ao elaborar tal exposição?

10) A exposição foi elaborada com o objetivo de atender a um público específico ou atende a qualquer público?

11) Como foi o processo de construção da exposição e quais foram as mudanças que ocorreram ao longo das edições?

12) Por que a Sociedade Max Planck escolheu e investiu no Brasil para a vinda da exposição "Túnel da Ciência 3.0"?

13) Quais foram as principais dificuldades enfrentadas pela Sociedade Max Planck para a vinda da exposição ao Brasil? Quais adaptações foram realizadas?

APÊNDICE E - Roteiro de entrevista semiestruturada - Representante do 
Departamento de Popularização e Difusão da Ciência e Tecnologia do Ministério da Ciência, Tecnologia e Inovação

\section{Formação Profissional e Atuação}

1) Qual é sua formação?

2) Como e quando aconteceu sua entrada no Ministério da Ciência, Tecnologia, Inovação e Comunicação?

3) Quais são suas atividades dentro do Ministério?

4) Qual é sua relação e experiências com projetos relacionados à divulgação científica? Qual é sua concepção de divulgação Científica?

\section{Histórico de atuação e concepções do MCTI}

5) Quais são os principais tipos de eventos apoiados pelo Ministério da Ciência Tecnologia,Inovação e Comunicação? Como acontece esse processo de escolha?

6) Qual é a importância e quais são as contribuições atribuídas pelo MCTIC para a realização de eventos ligados à Divulgação de Ciências?

7) Qual é a concepção de divulgação científica do MCTIC?

8) O MCTIC já apoiou financeiramente algum evento científico internacional antes? Qual a importância que vocês atribuem para aplicação de investimento em eventos com essa característica?

\section{O Túnel da Ciência 3.0 no Brasil e o MCTI}

9) Como foi o processo de contato do Instituo Max Planck até o fechamento da negociação para apresentação do Túnel da Ciência no Brasil?

10) Qual tipo de apoio o MCTIC forneceu para realização do Túnel da Ciência?

11) Quais são as principais dificuldades enfrentadas para a realização do evento no país?

12) Qual é a importância e quais são as contribuições de realizar o Túnel da Ciência 3.0 no Brasil?

13) Em sua opinião, qual é o perfil do público que mais se adequa à exposição? Qual é o objetivo principal da exposição?

14) Você acredita que a concepção de divulgação científica do MCTI está de acordo com a concepção da exposição e do Instituto Max Planck?

15) A exposição originalmente foi concebida na Alemanha e posteriormente visitou vários outros países. Você acredita que as diferenças culturais criam desafios para realização de eventos com essas características? Quais são eles?

APÊNDICE F - Roteiro de entrevista semiestruturada - Diretor da Produtora Geração

\section{Formação Profissional}

1) Qual é sua formação?

2) Como e quando aconteceu sua entrada na empresa Geração Produções?

3) Quais são suas atividades dentro da produtora? 


\section{Histórico da Empresa e contato com o Instituto Max Planck}

4) Quais são os principais tipos de evento produzidos pela empresa?

5) A Geração produções já atua no mercado há mais de 27 anos, vocês já produziram algum evento de divulgação científica antes? Qual? E alguma exposição científica?

6) $\mathrm{Na}$ apresentação institucional da empresa, vocês pontuam que uma das linhas de atuação são eventos na área de Educação. Quais os principais eventos que vocês produziram na área? A experiência com a produção desses tipos de eventos ajudou de alguma forma na produção do Túnel da Ciência?

7) Quais são as principais diferenças entre produzir uma exposição científica em relação a outros tipos de eventos que vocês estão acostumados a produzir?

8) $\mathrm{O}$ que o Sr. entende por divulgação científica e como esse conceito relaciona-se com o Túnel da Ciência?

\section{A produção do Túnel da Ciência 3.0 no Brasil}

9) Como foi o processo de contato do Instituo Max Planck até o fechamento da negociação?

10) Quais são as principais frentes de atuação da empresa para produção do evento?

11) $\mathrm{Na}$ apresentação Institucional da empresa, vocês afirmam que "cada projeto é analisado e soluções são criadas, materializadas e implantadas". Quais são os principais desafios enfrentados pela empresa para produção do Túnel da Ciência 3.0 no Brasil?

12) (Caso responda que não produziram exposições científicas antes). Quais são as adaptações e mudanças vocês realizaram dentro da empresa para produção desse evento?

13) Quais os tipos de profissionais envolvidos na produção desse evento em específico e suas funções?

14) Vocês realizaram o processo de publicidade, marketing e relações públicas do evento? Como aconteceu esse trabalho? Qual é o principal atributo utilizado pela empresa para promoção do evento? Qual é o motivo dessa escolha? Quais são as principais mídias contatadas?

15) Qual é o perfil do público que mais se adequa à exposição?

16) A Geração Produção tem alguma relação com a escolha dos monitores da exposição? Como foi esse processo?

17) A exposição originalmente foi concebida na Alemanha e posteriormente visitou vários outros países. Você acredita que as diferenças culturais criam desafios para realização de eventos com essas características? Quais são eles?

18) Em sua opinião, quais são os principais objetivos e contribuições do Túnel da Ciência 3.0?

APÊNDICE G - Roteiro de entrevista semiestruturada com os monitores

\section{I - Formação e experiências prévias}

1) Qual é sua formação acadêmica?

2) Você já atuou em alguma atividade de divulgação científica? Qual? Se sim, teve 
alguma preparação para isso (licenciatura, cursos...)?

3) Como soube da possibilidade de trabalhar como monitor da Exposição Túnel da Ciência?

4) Por que se interessou em trabalhar como monitor(a)? Quais eram suas expectativas quanto à experiência de trabalhar como monitor(a) nesta exposição?

\section{II - Experiências no Túnel da Ciência}

5) Em sua opinião, qual é o papel do monitor de uma exposição?

6) A partir da sua experiência até o momento, quais são as maiores dificuldades que o público enfrenta na interação com a exposição?

7) Em qual ou quais módulos você atua? Possui maior afinidade com algum deles?

8) Como você costuma atuar junto ao público? Por que fez essas escolhas de mediação?

9) Já teve alguma coisa que você começou a fazer e mudou porque viu que não dava certo?

10) Você pode relatar um bom exemplo de interação entre o visitante e a exposição? E um exemplo de interação que você julgue ruim?

11) Como foi sua capacitação para participar da monitoria da exposição? De que forma ajudou no exercício do trabalho? O que gostaria de ter vivenciado naquele momento?

12) Em relação ao público, o que você acha que os visitantes levam como resultado da visita à exposição?

\section{III - Relação com o público}

13) Qual é o perfil do público que mais se adequa à exposição?

14) Quais são os tipos de perguntas mais frequentes?

15) As pessoas conseguem usar bem os ipods?

16) A partir da sua experiência na exposição, você considera que os visitantes relacionam ou comparam as pesquisas brasileiras com as alemãs? Você percebe diferenças entre os diversos públicos?

17) Você constrói pontes entre as pesquisas apresentadas na exposição e pesquisas brasileiras? Você fala das instituições brasileiras que fazem pesquisa?

18) Em sua opinião, a exposição pode ser considerada um bom instrumento de divulgação da pesquisa do Instituto Max Planck? Por quê?

19) Você já teve alguma experiência na área de pesquisa? Qual?

20) Você acha que essa experiência te ajuda a mediar as questões apresentadas na exposição?

APÊNDICE H - Roteiro de entrevista semiestruturada - Público espontâneo - Pré visita

\section{Formação Profissional e Atuação}

1) Qual é sua escolaridade e sua formação?

2) Você já desenvolveu algum trabalho relacionado à Educação ou à Ciência?

3) Como era sua relação com as Ciências na escola? 
4) Qual é sua relação com a Ciência no dia a dia?

\section{Relação com museus e exposições científicas}

4) Você costuma frequentar museus ou exposições científicas? Quais você visitou no último ano? Como acontece esse processo de escolha? (Caso a resposta seja negativa, perguntar os motivos)

5) Em sua opinião, qual é a importância e quais são as contribuições da realização de eventos ligados à Divulgação de Ciências?

6) O que você entende por divulgação científica?

7) Qual motivo te impulsiona a visitar espaços como esse?

8) Você já teve alguma dificuldade nos museus frequentados (acesso, entendimento do conteúdo...)?

9) Quando você frequenta museus e exposições tem o hábito de pedir auxílio aos monitores? Que importância você atribui a eles?

\section{O Túnel da Ciência 3.0 no Brasil}

10) Como você ficou sabendo da realização do Túnel da Ciência 3.0 no Brasil? O que você ouviu a respeito da exposição?

11) O que te motivou a vir até a exposição?

12) Quais são suas principais expectativas e o que você espera encontrar?

13) A exposição Túnel da Ciência 3.0 mostra o avanço das pesquisas realizadas pelo Instituo Max Planck da Alemanha. Você acredita que existem diferenças entre a Ciência realizada na Alemanha e no Brasil? Quais?

14) Em sua opinião, qual é o perfil do público que mais se adequa à exposição? Qual o objetivo principal da exposição?

15) A exposição originalmente foi concebida na Alemanha e posteriormente visitou vários outros países. Você acredita que as diferenças culturais criam desafios para a realização de eventos com essas características? Quais são eles?

APÊNDICE I - Roteiro de entrevista semiestruturada - Público espontâneo - Pós visita

1) O que mais te impressionou na visita? Quais módulos mais te marcaram?

2) Quais foram as principais dificuldades enfrentadas?

3) Após a visita, como você definiria o objetivo da exposição?

4) Você acredita que a exposição atendeu às suas expectativas? (Pedir para explicar melhor). 